\title{
Depositional environments and sequence stratigraphy of the Rockwell-Price Formation in western Maryland, south-central Pennsylvania, and northern West Virginia
}

\author{
Darin A. Dolezal \\ West Virginia University
}

Follow this and additional works at: https://researchrepository.wvu.edu/etd

\footnotetext{
Recommended Citation

Dolezal, Darin A., "Depositional environments and sequence stratigraphy of the Rockwell-Price Formation in western Maryland, south-central Pennsylvania, and northern West Virginia" (2004). Graduate Theses, Dissertations, and Problem Reports. 2030.

https://researchrepository.wvu.edu/etd/2030
}

This Thesis is protected by copyright and/or related rights. It has been brought to you by the The Research Repository @WVU with permission from the rights-holder(s). You are free to use this Thesis in any way that is permitted by the copyright and related rights legislation that applies to your use. For other uses you must obtain permission from the rights-holder(s) directly, unless additional rights are indicated by a Creative Commons license in the record and/ or on the work itself. This Thesis has been accepted for inclusion in WVU Graduate Theses, Dissertations, and Problem Reports collection by an authorized administrator of The Research Repository @ WVU. For more information, please contact researchrepository@mail.wvu.edu. 
Depositional Environments and Sequence Stratigraphy of the Rockwell-Price Formation in Western Maryland, South-Central Pennsylvania, and Northern West Virginia

\author{
Darin A. Dolezal
}

\author{
Thesis Submitted to the \\ College of Arts and Sciences \\ at West Virginia University \\ in Partial Fulfillment of the Requirements \\ for the Degree of
}
Master of Science in Geology

Richard Smosna, Ph.D., Chair

Thomas Kammer, Ph.D.

John Beuthin, Ph.D.

Department of Geology and Geography

Morgantown West Virginia

2004

Keywords:

Depositional Environments, Sequence Stratigraphy, Price Formation, Rockwell Formation, Sedimentology

Copyright 2004 Darin A. Dolezal 


\begin{abstract}
Depositional Environments and Sequence Stratigraphy of the Rockwell-Price Formation in Western Maryland, South-Central Pennsylvania, and Northern West Virginia

Darin A. Dolezal
\end{abstract}

The Price Formation of northern West Virginia consists of Upper Devonian - Lower Mississippian siliciclastic rocks that are primarily marine. Members of the Price Formation include from oldest to youngest the Oswayo, Cussewago, Riddlesburg Shale, and Rockwell. Rocks of the Price Formation are considered to be of genetic and temporal equivalence to the Rockwell Formation in south-central Pennsylvania, western Maryland, and the eastern West Virginia panhandle.

The research attempts to (1) interpret sedimentary facies and their depositional environments and (2) identify stratigraphic relationships across six outcrops in the central Appalachian basin. Outcrops have been measured and described along a $150 \mathrm{~km}$ transect from (west) Rowlesburg, West Virginia, to (east) Crystal Spring, Pennsylvania. The six exposures, ranging from approximately 56 to 227 m thick, were visually divided into packages of similar rock (stratigraphic units) according to their physical appearance and carefully described. Corel Draw ${ }^{\circledR}$ software was used to digitally construct small-scale graphic logs from the unit descriptions. Field descriptions and graphic logs served as the basis for the identification of facies and interpretation of depositional environments. Correlation of outcrops and recognized trends led to statigraphic and paleogeographic relationships.

The lower Price Formation and equivalent Rockwell Formation of northern West Virginia, western Maryland, and south-central Pennsylvania represent rocks that were deposited 
in a shallow coastal embayment during a relatively slow transgression. The outcrop at Rowlesburg represents the mouth of the embayment with sediment deposited in a marineinfluenced outer lagoon located behind the barrier islands that closed off the embayment. East of Rowlesburg was the river-influenced inner lagoon with restricted subtidal and bayhead-delta facies. The outcrops at Finzel and LaVale are interpreted to be a part of the shallow embayment that was strongly influenced by fluvial processes and subject to only moderate tidal energy. Outcrops at Sideling Hill and Crystal Spring reflect the terrestrial realm of the embayment. Fluvial deposits at Sideling Hill and lake deposits at Crystal Spring overlie the Hampshire Formation red beds. Sandstone of the Cussewago Member represents transgressive beach sediments that changed facies as the beach migrated landward. The Cussewago is interpreted as a barrier island at Rowlesburg, Finzel, and LaVale. At Sideling Hill and Crystal Spring, however, it was a coastal beach.

Sequence stratigraphy places the Oswayo and Cussewago members of the PriceRockwell Formation into the transgressive systems tract. The transgressive sandstone represents the upper half of the package, and the maximum flooding surface lies in the overlying Riddlesburg Shale Member. 


\section{ACKNOWLEDGMENTS}

I must express my respect and sincerest gratitude for my advisor Dr. Richard Smosna. His optimism, encouragement, eagerness, and sense of humor have kept me motivated throughout this study. Lectures attended and papers written at WVU may be forgotten in the future but your friendship and guidance will last a lifetime. Dr Smosna, thank you for believing in me. I would also like to express my sincere thanks to Dr. Thomas Kammer and Dr. John Beuthin for their insight, faith, and support in completing this study.

My partner Shane P. Huffman deserves a special thanks for taking on this project and seeing it through. We have spent three years of our lives working together on this study and he has been a rock to lean on. Thank you, Shane, you are a dear friend and I could not have accomplished this without you.

I must thank my beautiful wife for her unconditional love and devotion for me during this time in our lives. She has been my guiding light since day one and if not for her I would not be where I am today. Sweetheart, thank you for your faith, your trust, and your love.

I thank my parents for their continual encouragement and support of my education. They have taught me that a solid work ethic and a strong sense of determination will open countless doors in the future. Thank you mom and dad for being the foundation on which I stand.

I thank Dominion E \& P, and my co-workers in Jane Lew for their support of accomplishing my degree.

Most importantly I thank God for giving me wisdom, strength, and the will to finish. When I didn't have the words, He provided. When I wanted to quit, He took my hand. I thank the Lord for the blessings in my life.

- The Lord is my strength and my shield; my heart trusts in Him, and I am helped. -Psalms 27:7 


\section{TABLE OF CONTENTS}

ACKNOWLEDGMENTS

Page

LIST OF TABLES

vii

LIST OF FIGURES

viii

INTRODUCTION

1

Purpose of Study

3

Area of Study

4

Methodology

REGIONAL STRATIGRAPHY 12

Oswayo Member 12

Cussewago Member

15

Riddlesburg Shale Member

Upper Member of the Rockwell

Formation and Rockwell Member

$\begin{array}{ll}\text { DEPOSITIONAL ENVIRONMENTS } & 18\end{array}$

$\begin{array}{ll}\text { Barrier Island } & 18\end{array}$

$\begin{array}{ll}\text { Description } & 18\end{array}$

Interpretation $\quad 30$

Marine-Influenced Outer Lagoon 42

Description $\quad 42$

Interpretation $\quad 58$

River-Influenced Inner Lagoon 59

Restricted Subtidal $\quad 59$

Description $\quad 59$

Interpretation $\quad 65$

$\begin{array}{ll}\text { Bayhead Delta } & 68\end{array}$

Description 68

Interpretation $\quad 75$

$\begin{array}{ll}\text { Lacustrine } & 77\end{array}$

$\begin{array}{ll}\text { Lake Beach } & 77\end{array}$

Description $\quad 77$

$\begin{array}{ll}\text { Interpretation } & 78\end{array}$

$\begin{array}{ll}\text { Lake Bottom } & 78\end{array}$

Description $\quad 78$

$\begin{array}{ll}\text { Interpretation } & 78\end{array}$

$\begin{array}{lr}\text { Fluvial } & 85\end{array}$

Description $\quad 85$

Interpretation $\quad 85$ 
$\begin{array}{ll}\text { Diamictite } & 86\end{array}$

Description $\quad 86$

Interpretation $\quad 86$

$\begin{array}{ll}\text { PALEOGEOGRAPHY } & 91\end{array}$

$\begin{array}{ll}\text { STRATIGRAPHIC INTERPRETATION } & 96\end{array}$

$\begin{array}{ll}\text { CONCLUSIONS } & 111\end{array}$

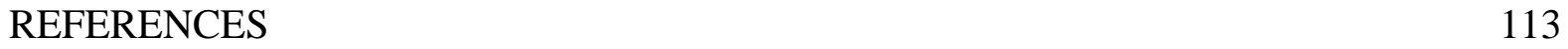

APPENDIX 1 - FIELD NOTES AND STRATIGRAPHIC COLUMNS 117

$\begin{array}{ll}\text { Column Symbols } & 118\end{array}$

1. Rowlesburg, West Virginia 119

2. Keysers Ridge, Maryland 137

3. Finzel, Maryland 145

4. LaVale, Maryland 154

5. Sideling Hill, Maryland 171

6. Crystal Spring, Pennsylvania 195

APPENDIX 2 - SEQUENCE STRATIGRAPHY 206

$\begin{array}{ll}\text { Introduction } & 207\end{array}$

$\begin{array}{ll}\text { History } & 209\end{array}$

Hierarchy of Stratal Units 210

Lamina, Lamina Sets, Beds, Bed Sets $\quad 210$

$\begin{array}{ll}\text { Parasequences } & 211\end{array}$

$\begin{array}{ll}\text { Parasequence Boundaries } & 212\end{array}$

$\begin{array}{ll}\text { Parasequence Set } & 214\end{array}$

Sequences 216

Lowstand Systems Tract (LST) 219

$\begin{array}{ll}\text { Incised Valleys } & 221\end{array}$

Transgressive Systems Tract (TST) 223

Highstand Systems Tract (HST) 224 


\section{LIST OF TABLES}

Table

Page

1. Summary of facies characteristics for the Barrier Island and 19

Marine-Influenced Outer Lagoon.

2. Summary of facies characteristics for the River-Influenced Inner Lagoon. 20

3. Summary of facies characteristics for the Fluvial and Lacustrine 21 environments. 


\section{LIST OF FIGURES}

Figures $\quad$ Page

1. Chronostratigraphic diagram showing stratigraphic relationships 2

in the central Appalachians, from Kammer \& Bjerstedt (1986).

2. Map showing location of six outcrops in the study area. 5

3. Outcrop photo near Rowlesburg, West Virginia 6

4. Outcrop photo at Finzel, Maryland $\quad 7$

5. Outcrop photo at LaVale, Maryland $\quad 8$

6. Outcrop photo of Sideling Hill, Maryland 9

7. Outcrop photo at Crystal Spring, Pennsylvania 10

8. Stratigraphic cross-section from Bluefield, West Virginia to 13

Crystal Spring, Pennsylvania, from Bjerstedt \& Kammer (1988).

9. Stratigraphic diagram showing member names relative to formation 14

names in the study area.

10. Rowlesburg stratigraphic column 22

11. Keysers Ridge stratigraphic column 23

12. Finzel stratigraphic column $\quad 24$

13. LaVale stratigraphic column 25

14. Sideling Hill stratigraphic column 26

15. Crystal Spring stratigraphic column 27

16. Photo ID \#1101: Photo shows the wedge-shaped beds in Unit 21 at LaVale. 28

17. Photo ID \#1118: Photo shows the contact (wave ravinement surface) 29 
indicated by the white arrow of Unit 2 with the underlying

diamictite at Sideling Hill.

18. Photo ID \#1138: Photo shows granule- to pebble-size quartz conglomerate layer in the base of Unit 10 at Crystal Spring.

19. Photo ID \#1139: Photo shows the pebbles in Unit 10 at Crystal Spring with a grain size scale.

20. Photo ID \#0658: Photo shows additional beds of quartz pebble layers in Unit 11 at Crystal Spring.

21. Photo ID \#1140: Photo shows scour surface (indicated by arrows) of conglomerate layer in Unit 10 at Crystal Spring.

22. Photo ID \#0657: Photo shows trough cross-stratification in Unit 10 at Crystal Spring.

23. Photo ID \#0659: Photo shows range of thickness of trough cross-stratification in Unit 11 at Crystal Spring. Notebook has cm scale.

24. Photo ID \#0660: Photo shows tool marks at the base of Unit 11 at Crystal Spring.

25. Photo ID \#1099: Photo shows erosive base of barrier island sandstone at the base of Unit 21 at LaVale overlain by wedge-shaped bedding.

26. Photo ID \#1104: Photo shows wave ravinement surface (indicated by arrow) at the base of Unit 24A at LaVale. Erosion into underlying diamictite is more obvious in outcrop.

27. Photo ID \#1113: Photo shows a thin gravel lag with grain size scale in the wave ravinement surface at the base of Unit 24A at LaVale. 
28. Photo ID \#1120: Photo shows dark gray to purple colored shale above the basal sandstone and below the scour based sandstone bed. This shale package is the Riddlesburg at Sideling Hill. Up section is to the upper right in the photo.

29. Photo ID \#1141: Photo shows bidirectional cross-stratification in Unit 10 at Crystal Spring.

30. Photo ID \#0572: Photo shows sharp basal contact (indicated by arrows) of Unit 34 at Rowlesburg. Note the large convex "conglomeratic bar” at the base. 31. Photo ID \#0569: Photo shows sharp basal contact (indicated by arrow) of Unit 32 at Rowlesburg. 32. Photo ID \#0497: Photo shows scouring (indicated by arrows) of Unit 24 into lower units at Rowlesburg.

33. Photo ID \#0571: Photo shows close-up of quartz pebble conglomerate (shown by arrow) at base of Unit 34 at Rowlesburg noted in figure 30 .

34. Photo ID \#0515: Photo shows low-angle inclined bedding above (indicated by line) and trough cross-bedding below in Unit 11 at Rowlesburg. 35. Photo ID \#0524: Photo shows large-scale planar cross-bedding in Unit 24 at Rowlesburg.

36. Photo ID \#0492: Photo shows trace fossils in the basal bedding plane of Unit 3 at Rowlesburg.

37. Photo ID \#0517: Photo shows large vertical burrow in Unit 11 at Rowlesburg.

38. Photo ID \#0510: Photo shows burrows in the basal bedding 
plane of Unit 11 at Rowlesburg.

39. Photo ID \#0512: Photo shows large horizontal burrow in the basal bedding plane of Unit 11 at Rowlesburg.

40. Photo ID \#0568: Photo shows horizontal burrow in the basal bedding plane of Unit 30 at Rowlesburg.

41. Photo ID \#0514: Photo shows brachiopods in the basal bedding plane of Unit 11 at Rowlesburg. bedding plane of Unit 11 at Rowlesburg.

43. Photo ID \#1087: Photo shows sharp basal contact of Unit 1 with the underlying Hampshire red beds at LaVale.

44. Photo ID \#1150: Photo shows coarsening and thickening upward beds at Finzel. Note the sharp basal contact with the Hampshire red beds. 45. Photo ID \#1093: Photo shows meter scale mud blocks encased in sandstone in Unit 4 at LaVale.

46. Photo ID \#1091: Photo shows two prominent vertical burrows (indicated by arrows) in Unit 4 at LaVale. Stratigraphic-up is to upper left. 47. Photo ID \#1152: Photo shows horizontal burrows in the basal bedding plane of Unit 4 at Finzel, pencil for scale.

48. Photo ID \#1151: Photo shows lenticular bedding in Unit 4 at Finzel. 66

49. Photo ID \#1162: Photo shows a possible paleosol in Unit 8 at Finzel. Rust colored areas (for example, inside circle) appeared to be mottled root traces on outcrop. 
50. Photo ID \#1156: Photo shows a fining-upward sequence of

distributary channels with intermediate shale breaks in Unit 13

at Finzel.

51. Photo ID \#1157: Photo shows erosional scour base (indicated by arrow)

of the distributary channel sandstone in Unit 11 at Finzel.

52. Photo ID \#1160: Photo shows flaser bedding in Unit 13b at Finzel.

53. Photo ID \#1158: Photo shows internal channelized bed forms within

Unit 13b at Finzel.

54. Photo ID \#1094: Photo shows a coarsening-upward trend in

Unit 17 at LaVale, notebook for scale.

55. Photo ID \#1096: Photo shows sandstone beds thickening

upward in Units 10 \& 11 at LaVale, notebook for scale.

56. Photo ID \#1097: Photo shows a sharp basal contact of

Unit 13 at LaVale, notebook for scale.

57. Photo ID \#1128: Photo shows locally developed load casts in

Unit 1 at Crystal Spring.

58. Photo ID \#1129: Photo shows a sharp basal contact of

Unit 1 with the underlying Hampshire at Crystal Spring. Note the shale is squeezed up into the overlying sandstone.

59. Photo ID \#1132: Photo shows a cross-sectional view of ripple bedding (indicated by arrows) in the sandstone of Unit 5 at Crystal Spring. 60. Photo ID \#1136: Photo shows a laminated siltstone "laminite” in Unit 5 at Crystal Spring. 
61. Photo ID \#1137: Photos shows a close-up view of the laminite

of Unit 5 at Crystal Spring.

62. Photo ID \#1130: Photo shows the diaperic structures in a shale

bed of Unit 11 just above the diamictite at Crystal Spring.

63. Photo ID \#1103: Photo shows clasts (indicated by arrows) in the diamictite of Unit 23 at LaVale.

64. Photo ID \#1131: Photo shows a large clast in the diamictite of Unit 6 at Crystal Spring.

65. Photo ID \#1102: Photo shows the massive and structureless

form of the diamictite of Unit 23 at LaVale, notebook for scale.

66. Location map showing the interpreted paleoshoreline in relation

to the six outcrops in the study area.

67. Diagram showing a simple cross-sectional profile of the interpreted depositional environments. No scale implied.

68. Map showing the interpreted transgression of the barrier island at Time 1 .

Map illustrates the position of the barrier islands just west of Rowlesburg.

69. Lithostratigraphic cross-sections A \& B of the six outcrops in the study area

from Rowlesburg, WV to Crystal Spring, PA.

70. Map showing the interpreted transgression of the barrier island at Time 2 .

Map illustrates the barrier island being deposited at Rowlesburg and the

bayhead delta to the east.

71. Map showing the interpreted transgression of the barrier island at Time 3. Map illustrates the barrier island being deposited at Finzel and LaVale. 
72. Map showing the interpreted transgression of the barrier island at Time 4 . Map illustrates a coastal beach being deposited at Sideling Hill and Crystal Spring.

73. Stick diagram (all columns are to the same scale) showing correlation of all depositional environments and sequence stratigraphic units from west to east. Datum is the base of the barrier/coastal sandstone.

74. Stick diagram (all columns are to the same scale) showing correlation of the sequence stratigraphic systems tracts from west to east. Datum is the base of the barrier/coastal sandstone.

75. Stick diagram (all columns are to the same scale) showing 109 correlation of the sequence stratigraphic surfaces from west to east. Datum is the base of the barrier/coastal sandstone. 


\section{INTRODUCTION}

The Price Formation of northern West Virginia consists of Upper Devonian - Lower Mississippian siliciclastic rocks that are primarily marine. In northern West Virginia the formation lies above red beds of the Hampshire Group and below limestones of the Greenbrier Group (Fig.1). Members of the Price Formation include from oldest to youngest the Oswayo,

Cussewago, Riddlesburg Shale, and Rockwell. Rocks of the Price Formation are considered to be of genetic and temporal equivalence to the Rockwell Formation in south-central Pennsylvania, western Maryland, and the eastern West Virginia panhandle (Bjerstedt \& Kammer, 1988).

Lithologies of the Price Formation of West Virginia range from continental conglomeratic sandstone to basinal black shale. Depositional environments include fluvial, deltaic, shelf, submarine fan, and basin floor (Kammer and Bjerstedt, 1986). To the east in Allegany County, Maryland, and Mineral County, West Virginia, the distinctive Oswayo Member pinches out, and the entire package of rocks is there referred to as the Rockwell Formation.

The Rockwell Formation in Maryland lies above red beds of the Hampshire Formation and below the Purslane Formation. Members of the Rockwell include the Oswayo, Cussewago, the Riddlesburg Shale, and an upper unnamed member. Lithologies of the Rockwell include polymictite diamictite, fine- to medium-grained well-sorted, cross-bedded sandstone, dark-gray siltstone and shale with coal lenses, and root-mottled siltstones and claystones interbedded with lenticular sandstones. Depositional environments range from marine to estuarine to alluvial plain (Brezinski, 1989). The Oswayo Member is interpreted as restricted 


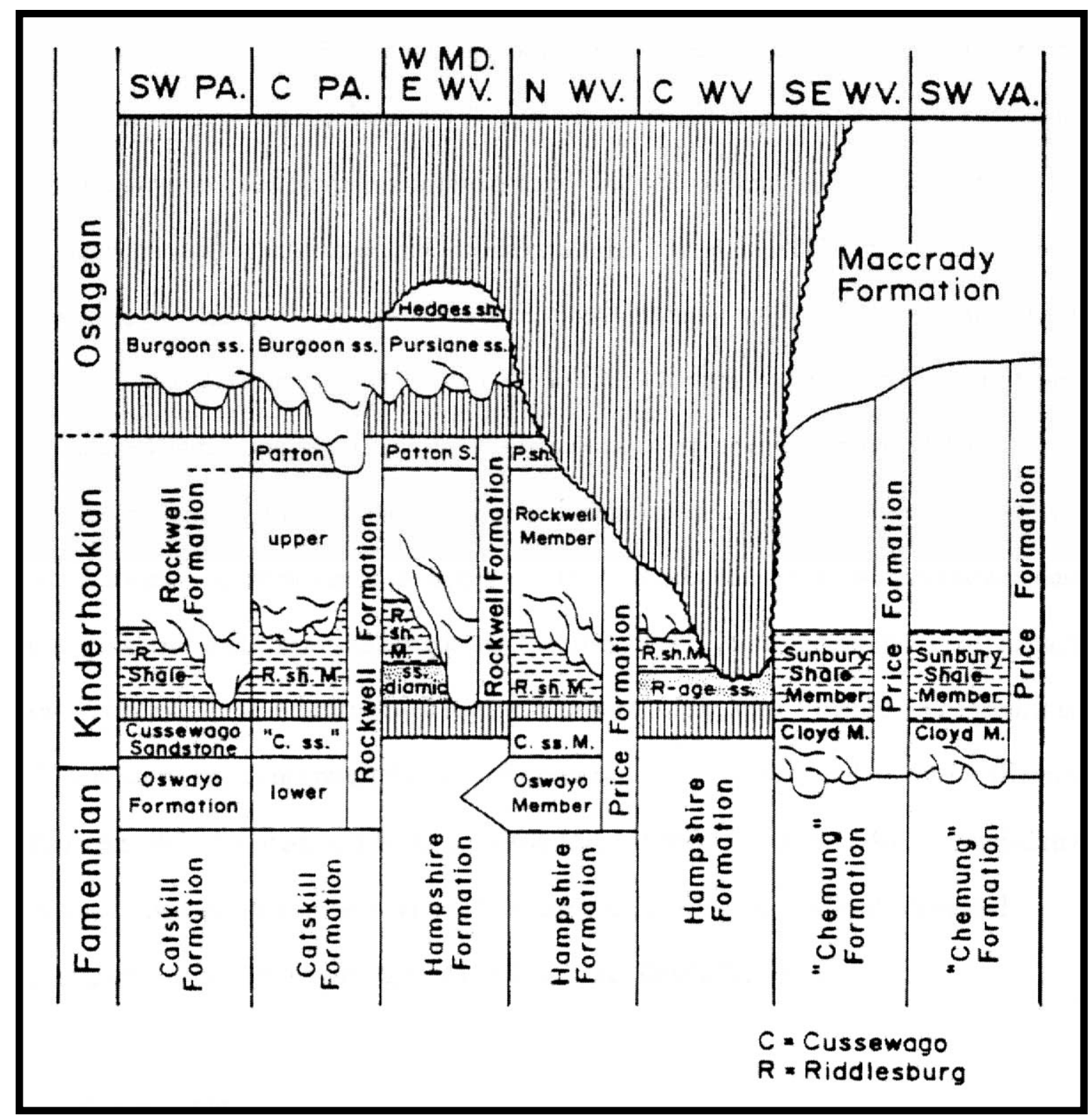

Figure 1. Chronotratigraphic diagram showing stratigraphic relationships in the central Appalachians, from Kammer \& Bjerstedt (1986). The base of the Kinderhookian is now interpreted as the base of the Riddlesburg Shale (Carter \& Kammer, 1990). 
bay. The Cussewago is a beach or tidal flat. The Riddlesburg Member is interpreted as a backbar lagoon.

The lower quarter of the Rockwell Formation in Pennsylvania is predominantly sandstone. The middle is a mixture of interbedded sandstone, siltstone, and shale that is mostly green-gray to olive-gray with some red beds present. The marine Riddlesburg Shale Member is brown-gray to black-gray and occurs near the middle of the Rockwell. The upper quarter is sandy and shaly with fining upward cycles and coal seams. The dominant depositional environment is interpreted as fluvial systems of primarily high-sinuosity meandering rivers. However, marginal marine environments such as estuaries and interdistributary bays also occurred (Berg, 1999).

\section{Purpose of Study}

The focus of this thesis research is the Devonian-Mississippian Rockwell Formation in western Maryland and Pennsylvania and the equivalent Price Formation in adjacent West Virginia. The research attempts to (1) interpret sedimentary facies and their depositional environments, and (2) identify stratigraphic relationships across six outcrops in the central Appalachian basin. Vertical as well as lateral facies relationships are identified based on sequence-stratigraphic analysis of the Rockwell-Price. A sequence-stratigraphic framework for this formation has not been previously established. It is the hope of the author to make a significant contribution to our understanding of Appalachian basin stratigraphy in general and Devovian-Mississippian gas-producing sandstones in particular.

The thesis was undertaken in cooperation with Shane Huffman (MS thesis, West Virginia University, in preparation). Field work and stratigraphic-sedimentary interpretations of the 
entire Rockwell-Price Formation were done together, but my research presents only the lower portion, the Upper Devonian strata. Shane Huffman's thesis will address the upper portion, the Lower Mississippian strata.

\section{Area of Study}

Six outcrops have been measured and described along a $150 \mathrm{~km}$ transect from Rowlesburg, West Virginia, to Crystal Spring, Pennsylvania (Fig. 2). Designated outcrops include:

(1) Rowlesburg, Preston County, WV (Fig. 3). Exposure along the railroad tracks across the Cheat River from the town of Manheim. Approximately $2.1 \mathrm{~km}(1.3 \mathrm{mi})$ (map distance) northwest of Rowlesburg. At this outcrop $153 \mathrm{~m}$ of section were measured and described.

(2) Keysers Ridge, Garrett County, MD. Road cut along the north side of I-68, immediately west of the interchange with U.S. Route 219 at Keysers Ridge. At this outcrop $56 \mathrm{~m}$ of section were measured and described.

(3) Finzel, Garrett County, MD (Fig. 4). Road cut along the north side of I-68 immediately east of the Finzel entrance/exit ramps. At this outcrop $61 \mathrm{~m}$ of section were measured and described.

(4) LaVale, Alleghany County, MD (Fig. 5). Road cut along south side of I-68, $1.1 \mathrm{~km}$ $(0.7 \mathrm{mi})$ west of the overpass of State Route 53 and $2.2 \mathrm{~km}(1.4 \mathrm{mi})$ west of the eastbound exit at LaVale. At this outcrop $145 \mathrm{~m}$ of section were measured and described.

(5) Sideling Hill, Washington County, MD (Fig. 6). Road cut along I-68 through the synclinal mountain of Sideling Hill; section measured along the north side of the highway. At this outcrop $227 \mathrm{~m}$ of section were measured and described.

(6) Crystal Spring, Fulton County, PA (Fig. 7). Road cut along the east side of I-70, approximately $1 \mathrm{~km}(0.6 \mathrm{mi})$ north of the entrance ramp from Crystal Spring. At this outcrop 120 $\mathrm{m}$ of section were measured and described. 


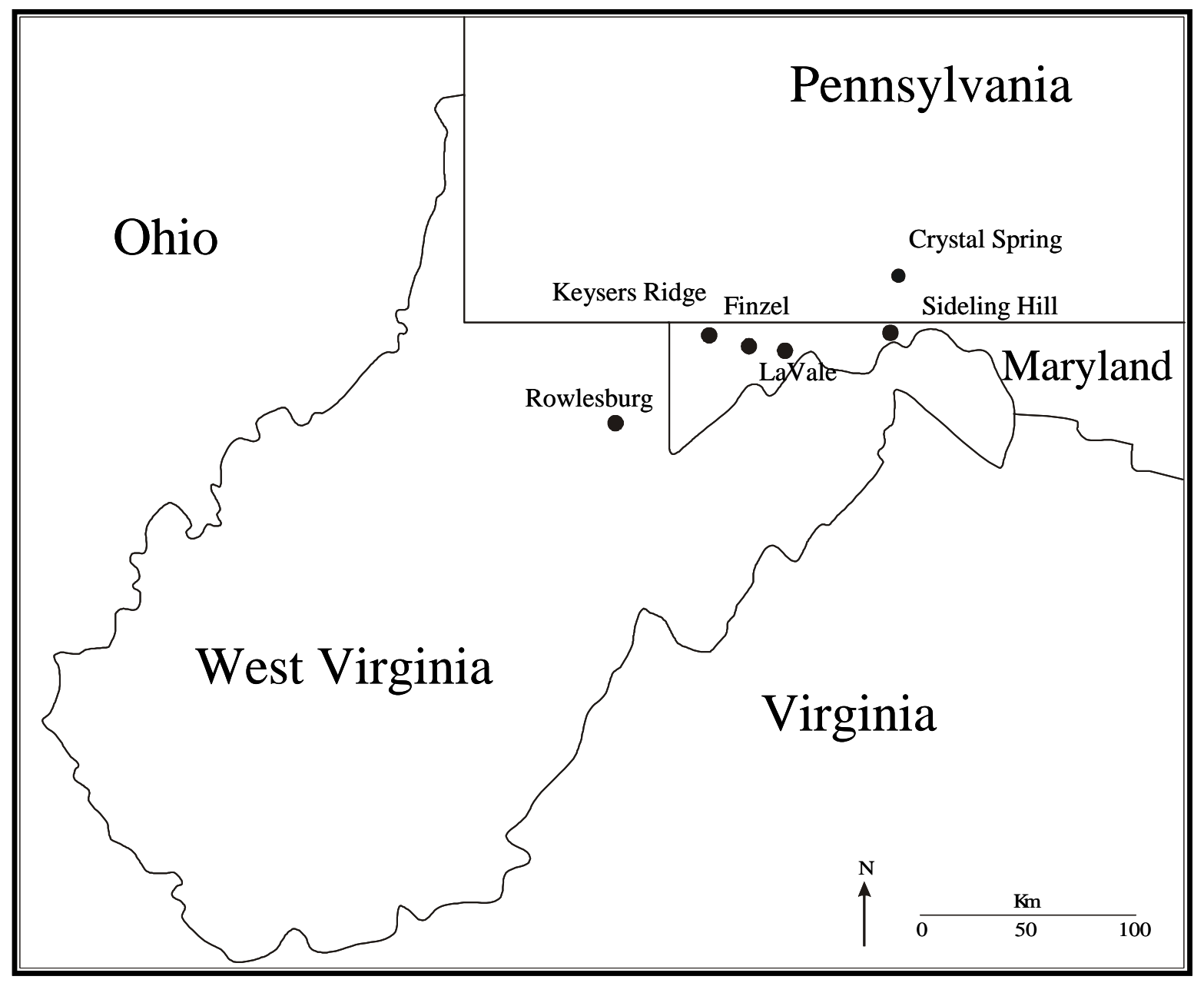

Figure 2. Map showing location of six outcrops in the study area. 


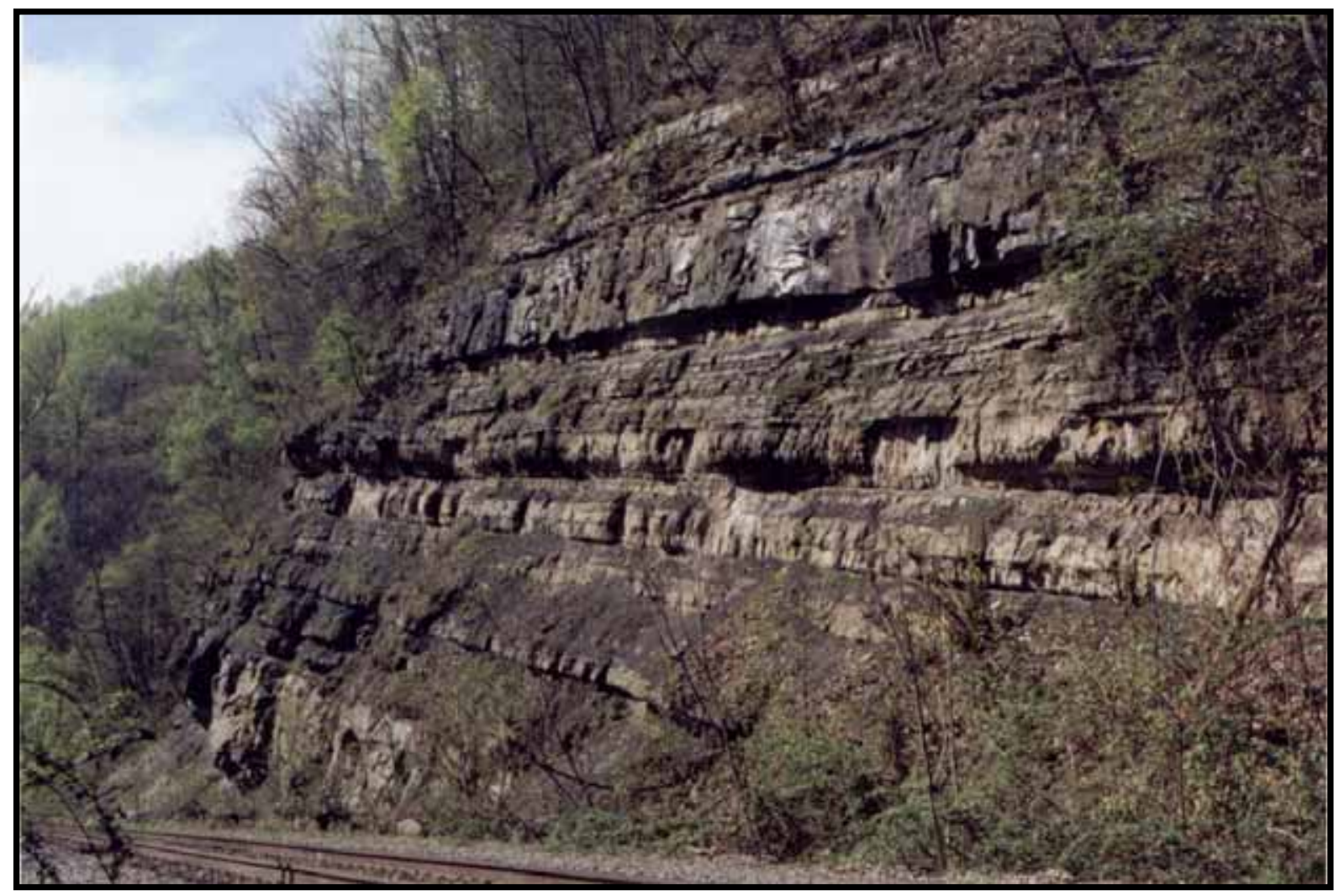

Figure 3. Outcrop photo near Rowlesburg, West Virginia 


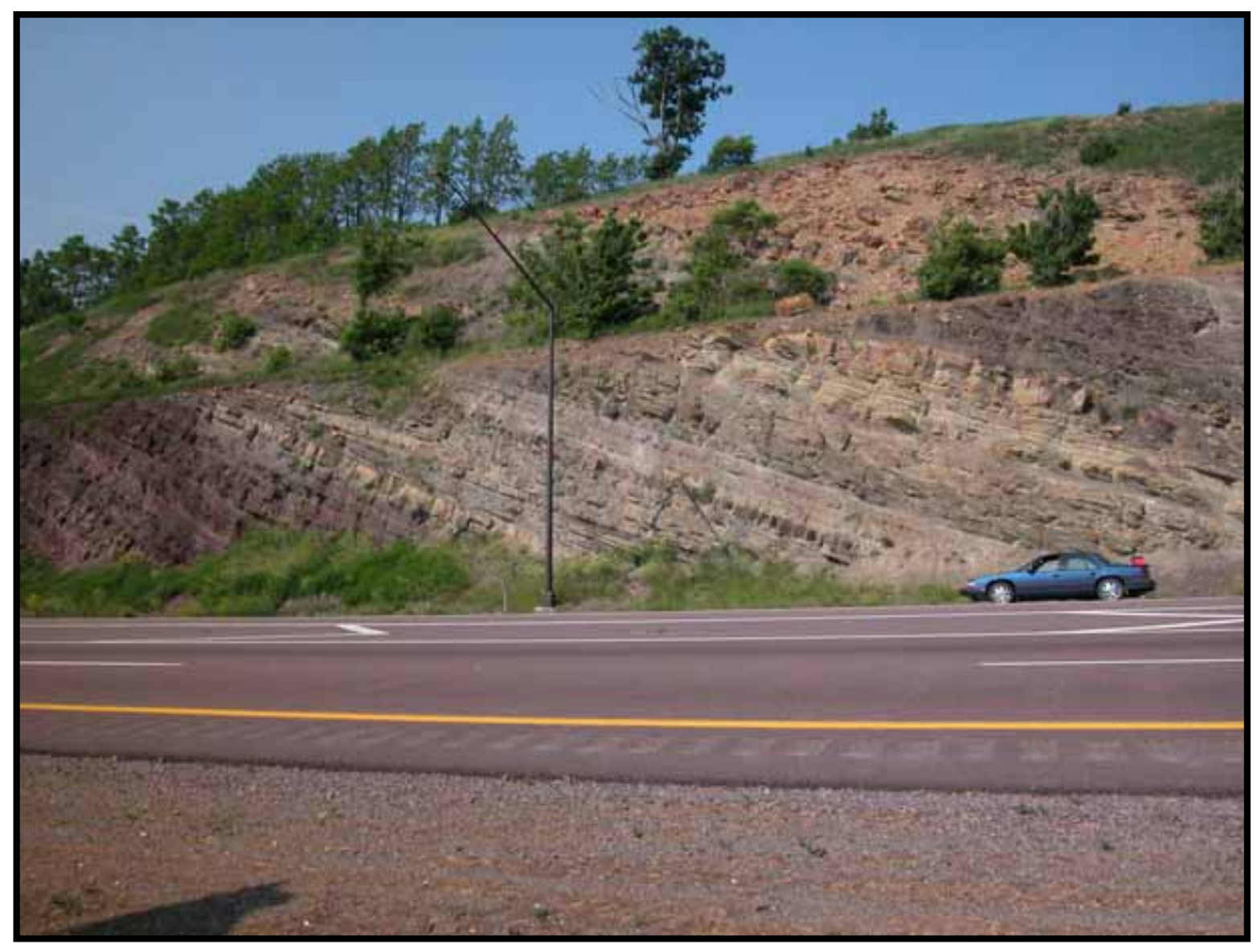

Figure 4. Outcrop photo at Finzel, Maryland 


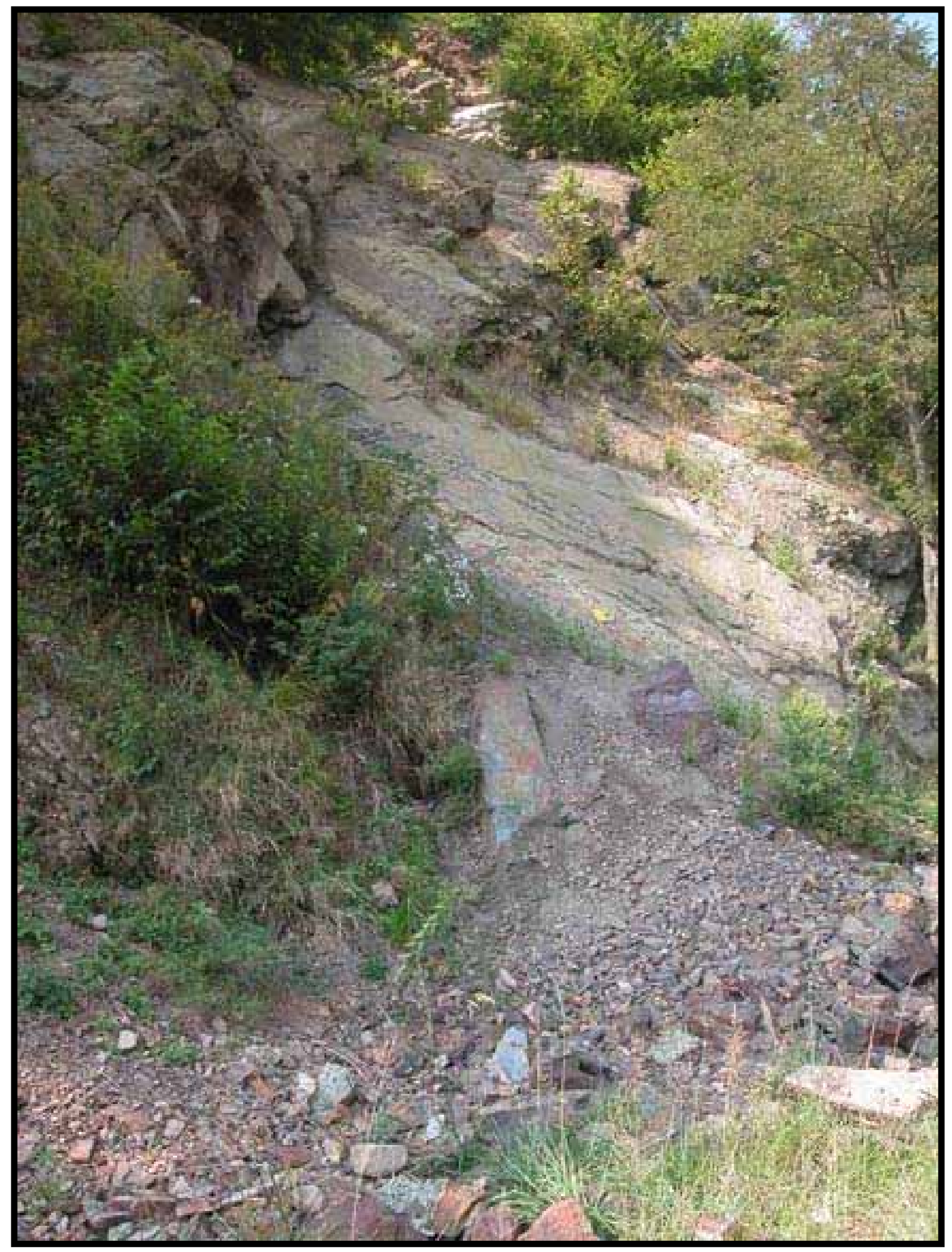

Figure 5. Outcrop photo at LaVale, Maryland 


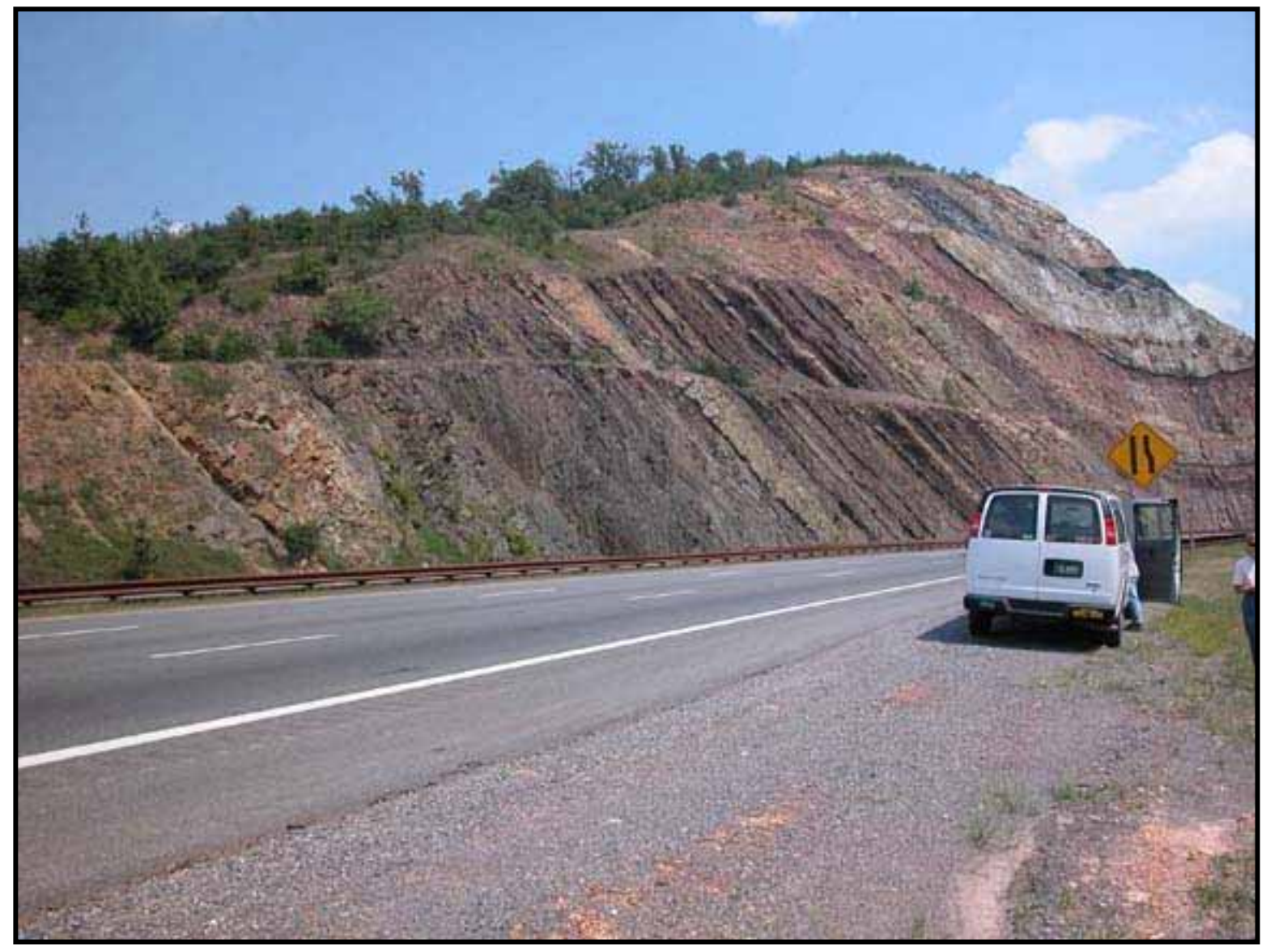

Figure 6. Outcrop photo of Sideling Hill, Maryland 


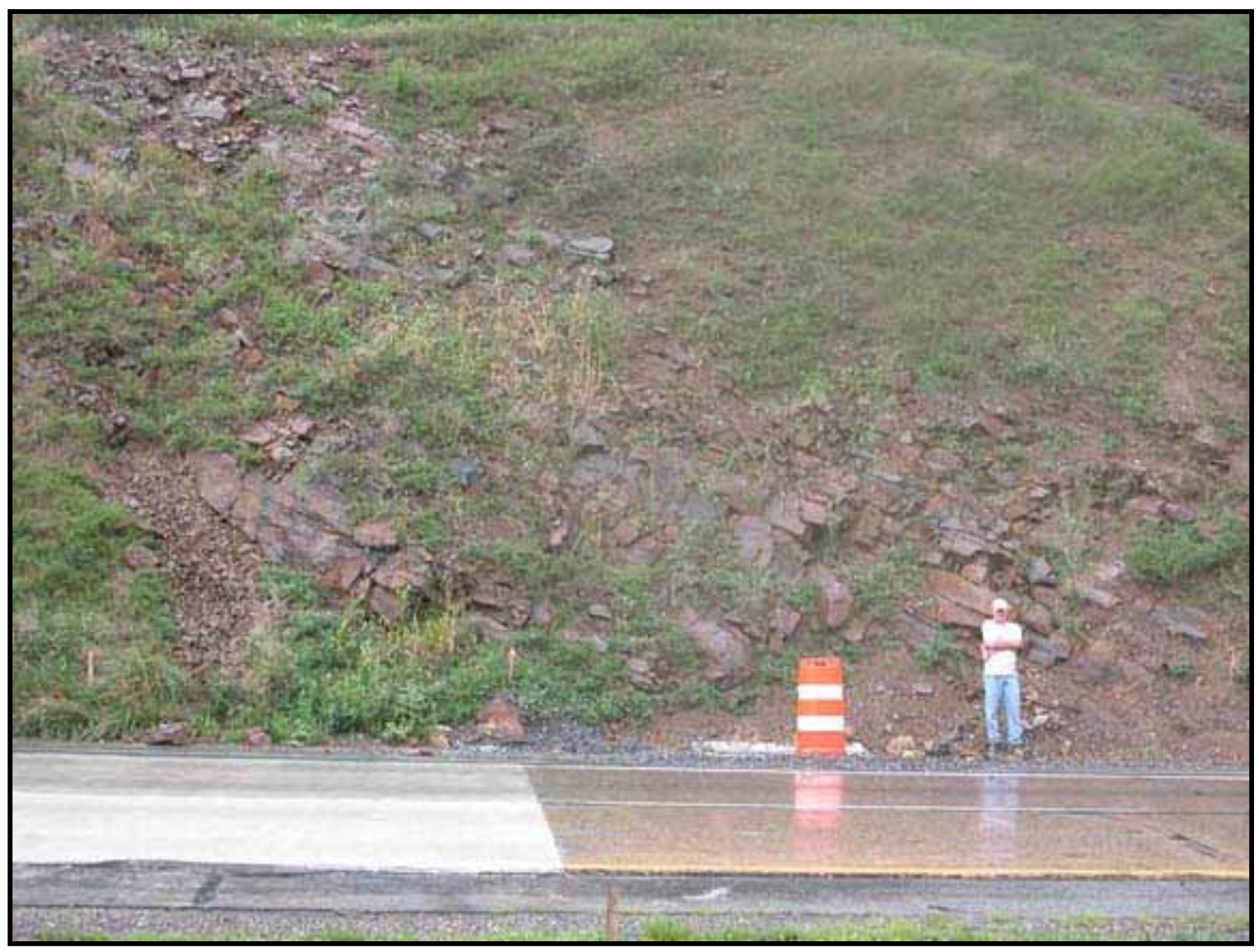

Figure 7. Outcrop photo at Crystal Spring, Pennsylvania 


\section{Methodology}

The six exposures, ranging from approximately 56 to 227 m thick, were visually divided into packages of similar rock (stratigraphic units) according to their physical appearance.

Careful detail was taken to record unit thickness, rock name, mineral content, rock color, texture, bedding, other sedimentary structures, and trace and body fossils. Once the fieldwork was complete, Corel Draw ${ }^{\circledR}$ software was used to digitally construct small-scale graphic logs from the unit descriptions. Each column was redrafted in 20-m sections (large-scale) for the Appendix.

Field descriptions and graphic logs served as the basis for the identification of facies and interpretation of depositional environments. Correlation of outcrops and recognized trends led to statigraphic and paleogeographic relationships. Finally all data and interpretations were put into a sequence-stratigraphic framework. 


\section{REGIONAL STRATIGRAPHY}

In the central Appalachian basin, Kammer \& Bjerstedt (1986) and Bjerstedt \& Kammer (1987) identified two individual depocenters (north and south) of the Rockwell-Price Formation separated by the West Virginia Dome (Fig. 8). Members in the northern depocenter (this study) include, from oldest to youngest, the Oswayo, Cussewago, Riddlesburg Shale, and Rockwell (Fig. 9). The Oswayo and the Cussewago Members are part of the Upper Devonian. The Riddlesburg Shale Member and the Rockwell Member above the Riddlesburg Shale are Lower Mississippian in West Virginia. Farther east the Rockwell expands into the Upper Devonian at Sideling Hill. Bjerstedt (1987) included the Oswayo in the Price Formation of northern West Virginia but as a member of the Hampshire Formation in Maryland and below the Rockwell Formation. Brezinski (1989), however, included the Oswayo Member in the Rockwell of Maryland. This present study follows the stratigraphic nomenclature of Brezinski (1989) in that the base of the Rockwell Formation is placed at the base of the lowest thick non-red sandstone, that is, at the base of the Oswayo-which is Upper Devonian.

\section{Oswayo Member}

The Oswayo Member, also called the Finzel Marine Tongue Member by Brezinski (1989) and by Dennison et al. (1986), was originally defined by Glenn (1903) for interbedded, olive-green to rusty-brown sandstone, siltstone and silty shale containing abundant fossils. The name comes from exposures in Oswayo Creek, near Olean, New York (Bjerstedt, 1987). A reference section for the Oswayo is exposed near Rowlesburg West Virginia, and secondary exposures are located at Finzel and LaVale, Maryland (Bjerstedt \& Kammer, 1988). Kammer and Bjerstedt (1986) described the lithology at Rowlesburg as interbedded gray and green 


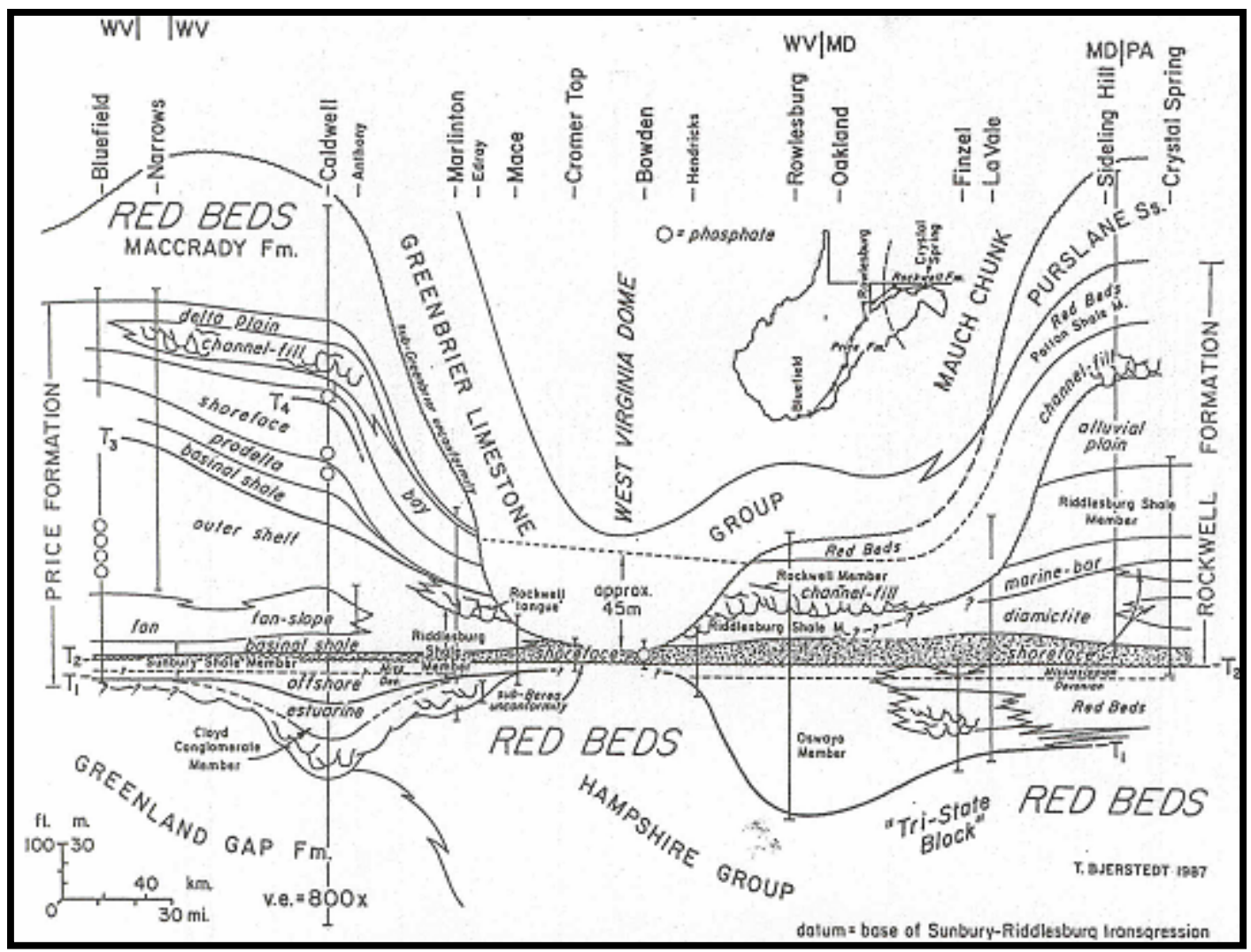

Figure 8. Stratigraphic cross-section from Bluefield, West Virginia to Crystal Spring, Pennsylvania, from Bjerstedt \& Kammer (1988). Datum is the Riddlesburg Shale 


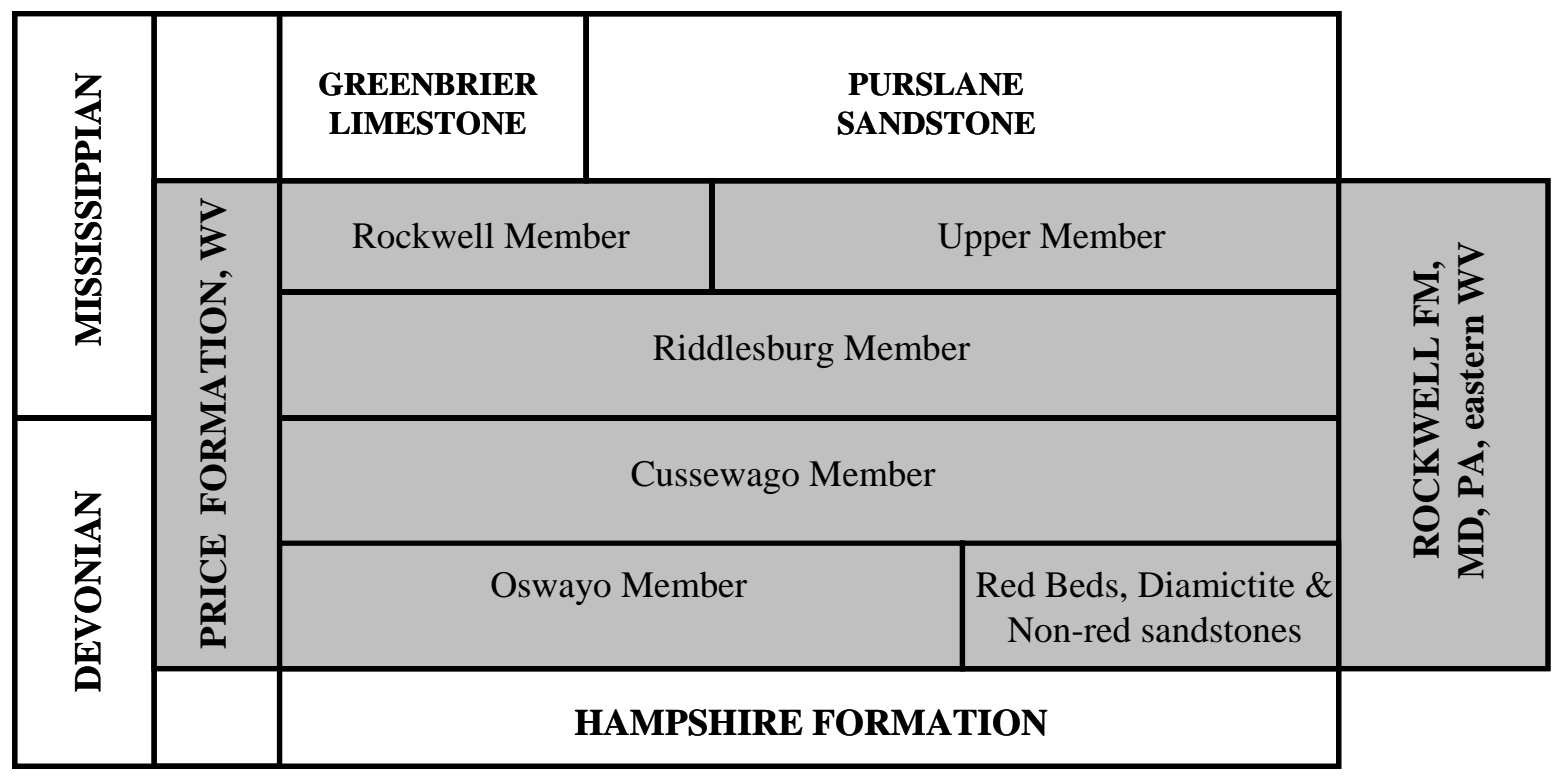

Figure 9. Stratigraphic diagram showing member names relative to formation names in the study area. Diamictite occurs in the Riddlesburg at LaVale and within the Fluvial and Lacustrine environments (below Cussewago) at Sideling Hill and Crystal Spring. 
sandstone, siltstone, and silty shale with a thickness of roughly $65 \mathrm{~m}$. It usually weathers a rustybrown color. Bjerstedt and Kammer (1988) also described the Oswayo as being locally fossiliferous and bioturbated, and Bjerstedt (1987) identified several trace-fossil assemblages.

The Oswayo Member is stratigraphically thickest at Rowlesburg, West Virginia. To the east, the Oswayo thins at Finzel and LaVale, Maryland, and pinches out just west of Sideling Hill, Maryland. Eastward transgression of the Late Devonian sea produced this tongue of the Oswayo. Marine body fossils indicate a range of salinity conditions in low-energy depositional environments (Bjerstedt, 1987 ; Bjerstedt and Kammer, 1988).

\section{Cussewago Member}

The Cussewago is a sheet-sand of variable thickness overlying the Oswayo Member (Carter and Kammer, 1990). In West Virginia the sandstone consists of pebbly beds with fossil lags, whereas eastward the sandstone lacks fossils.

Bjerstedt and Kammer (1988) found the Cussewago thickest in north-central West Virginia, and thinner but coarser-grained in western Maryland. Exposures of this member can be observed at Rowlesburg, LaVale, Finzel, Sideling Hill, and, Crystal Spring. This study correlates the Cussewago at LaVale differently than Bjerstedt \& Kammer (1988) by excluding the diamictite and overlying sandstone. This study correlates the sandstone below the diamictite at LaVale as the Cussewago. The reason is based on stratigraphic thickness of the Cussewago at other outcrops being more compatible with the thickness of the lower sandstone at LaVale. A second reason is the diamictite and overlying sandstone allows for a Riddlesburg equivalence at LaVale. 


\section{Riddlesburg Shale Member}

The Riddlesburg Shale was defined by Reger (1927) for outcrops along the western edge of the Broad Top basin, 2.5 km northwest of Riddlesburg, Pennsylvania (Bjerstedt \& Kammer, 1988). The Riddlesburg is a package of heterolithic shale, thin-bedded siltstone and fine-grained sandstone. In West Virginia the Riddlesburg Shale is a member of the Price Formation but can be traced into Maryland and Pennsylvania where it is known as a member of the Rockwell Formation.

The unit represents a marine transgression over the underlying Cussewago. The formation reflects a shallow-offshore environment in northern West Virginia and a back-bar lagoon to the east in Maryland (Bjerstedt, 1987).

The Devonian-Mississippian boundary occurs at the contact of the Cussewago and Riddlesburg Shale (Carter \& Kammer, 1990). Index fossil Schuchertella macensis n. sp. is an Early Mississippian (Kinderhookian) brachiopod that occurs in the Riddlesburg Shale.

Schuchertella bowdenensis n. sp. is a Late Devonian (Famennian) brachiopod that occurs in the Cussewago member. Reevaluation by Carter and Kammer (1990) of Rockwell-Price brachiopods has shown the Cussewago is Famennian in age.

Upsection in the Riddlesburg are fining-upward yellow, brown, and reddish siltstone and mudstone which Bjerstedt (1986) interpreted to represent a transition from subaqueous, brackishwater deposition to subaerial deposition. This transition is further supported by the development of paleosols on a well-drained interfluvial area on the alluvial plain. The interfluvial area marks the beginning of the Rockwell Member of the Price Formation. 


\section{Upper Member of the Rockwell Formation and Rockwell Member}

The unnamed upper member of the Rockwell Formation represents the nomenclature in Maryland and Pennsylvania (Fig.9). The Rockwell Member, on the other hand, represents the upper section of the Price Formation in West Virginia. The Rockwell was named for outcrops along Rockwell Run, a tributary of the Potomac River in Morgan County, West Virginia (Stose \& Swartz, 1912 in Bjerstedt, 1986). The best exposure of the upper Rockwell is at Sideling Hill, Maryland.

The upper Rockwell is characterized by channel and crevasse-splay sandstones that exhibit fining-upward sequences (Bjerstedt, 1986). The majority of channel sandstones are fine-

to medium-grained, but some are coarser. Sedimentary structures include large- to medium-scale trough cross-bed sets and horizontal laminations. Laterally discontinuous red beds are present. The mudstone is massive and breaks into irregular pieces with a conchoidal fracture. The redmudstone lithofacies and coaly shale represents overbank fines of an alluvial plain environment. Above the Rockwell Member in West Virginia is a major unconformity that separates the Price Formation from the overlying Middle to Upper Mississippian Greenbrier Limestone (Kammer \& Bjerstedt, 1986). Above the Rockwell Formation in Maryland and Pennsylvania is the Purslane or Burgoon Sandstone, possibly with an unconformable contact (Kammer \& Bjerstedt, 1986). 


\section{DEPOSITIONAL ENVIRONMENTS}

This study has identified 6 facies of a marine embayment. Barrier island, outer lagoon, inner lagoon, lacustrine, fluvial, and diamictite. Facies characteristics are summarized in Tables 1-3, and stratigraphic columns are presented in figures 10-15.

\section{Barrier Island}

Description - At the Rowlesburg outcrop (Units 36 and 37a), the sandstone body is $17 \mathrm{~m}$ thick and fines upward from medium- to very-fine-grained sandstone. Shale interbeds are present at the top. Bedding is thick to very thick. The basal contact is sharp and erosional, and the dominant sedimentary structures include horizontal stratification and trough cross-bedding. The sandstone appears horizontally burrowed. Bjerstedt (1987) identified a trace fossil assemblage of Skolithos, Planolites, Phycodes, Isopodichnus, and Arenicolites. Carter and Kammer (1990) identified the Late Devonian brachiopod Cyrtospirifer sp. at this outcrop.

At the LaVale outcrop (Units 21 and 22), sandstone is $23 \mathrm{~m}$ thick. The sandstone exhibits a coarsening-upward trend from fine- to medium-grained with minor interbedded shale toward the top. Some sandstone beds appear wedge-shaped (Fig. 16) with internal scoured surfaces. Sedimentary structures include bi-directional, large-scale planar cross-stratification and horizontal lamination. The sandstone also contains shale clasts which become more abundant near the top. Bjerstedt (1987) identified Skolithos near the top of the sandstone.

At the Sideling Hill outcrop (Unit 2), the sandstone body exhibits a fining-upward sequence from coarse- to medium-grained. The sandstone, $18.2 \mathrm{~m}$ thick, appears clean and well sorted and contains no shale partings. Bedding is medium to thick. Although the contact is sharp with the underlying diamictite (Fig. 17), the base of the sandstone contains pebble-size quartz grains and shale clasts. Sedimentary structures grade vertically from horizontal 


\begin{tabular}{|c|c|c|c|c|c|}
\hline $\begin{array}{l}\text { Depositional } \\
\text { Environment }\end{array}$ & Thickness & Facies & Lithology & Physical Features & Biological Features \\
\hline Barrier Island & $16-23 \mathrm{~m}$ & Shoreface & $\begin{array}{l}\text { Medium-to very fine- } \\
\text { grained sandstone. } \\
\text { Poorly sorted to well } \\
\text { sorted. } \\
\text { Fining-upward sequences. }\end{array}$ & $\begin{array}{l}\text { 16-20 m thick beds. } \\
\text { Sharp erosional basal } \\
\text { contact w/pebble lag. } \\
\text { Discontinuous wedge- } \\
\text { shaped beds. Common } \\
\text { horizontal, trough, low- } \\
\text { angle, and planar } \\
\text { stratification. Rare tool } \\
\text { marks. }\end{array}$ & $\begin{array}{l}\text { Trace fossils } \\
\text { include: Skolithos, } \\
\text { Planolites, } \\
\text { Phycodes, } \\
\text { Isopodichnus, \& } \\
\text { Arenicolites }\end{array}$ \\
\hline $\begin{array}{l}\text { Marine- } \\
\text { Influenced } \\
\text { Outer Lagoon }\end{array}$ & $70 \mathrm{~m}$ & $\begin{array}{l}\text { Tidal } \\
\text { Channels } \\
\text { \& Open } \\
\text { Subtidal }\end{array}$ & $\begin{array}{l}\text { Medium-to very fine- } \\
\text { grained sandstone with } \\
\text { siltstone and shale } \\
\text { interbeds. Fining-upward } \\
\text { sequences. }\end{array}$ & $\begin{array}{l}1-8 \mathrm{~m} \text { thick sandstone beds. } \\
\text { Bedding is medium-very } \\
\text { thick. Erosional basal } \\
\text { contact with channel lag. } \\
\text { Common horizontal } \\
\text { bedding/laminations, large } \\
\text { scale trough and planar } \\
\text { cross-stratification, and } \\
\text { ripple bedding. Reactivation } \\
\text { surfaces. Few wedge shaped } \\
\text { beds. }\end{array}$ & $\begin{array}{l}\text { Common } \\
\text { bioturbation. Body } \\
\text { fossils include: } \\
\text { brachiopods, } \\
\text { crinozoan, } \\
\text { bryozoans, and } \\
\text { bivalves. Trace } \\
\text { fossils include: } \\
\text { Arenicolites, } \\
\text { Arthrophycus, } \\
\text { Bifungites, } \\
\text { Chondrites, } \\
\text { Cruziana, } \\
\text { Dimorphichnus, } \\
\text { Diplocraterion, } \\
\text { Paleophycus, } \\
\text { Planolites, } \\
\text { Rhizocorallium, } \\
\text { Rosselia, Skolithos, } \\
\text { \& Thalassinoides. }\end{array}$ \\
\hline & & $\begin{array}{l}\text { Washover } \\
\text { Deposits }\end{array}$ & $\begin{array}{l}\text { Thick shale with } \\
\text { interbedded siltstone and } \\
\text { very-fine to fine-grained } \\
\text { sandstone lenses }\end{array}$ & $\begin{array}{l}10 \mathrm{~cm}-1 \mathrm{~m} \text { thick sandstone } \\
\text { beds. Bedding is thin- } \\
\text { medium with lateral } \\
\text { discontinuity. Sharp basal } \\
\text { contacts. Common small- } \\
\text { scale cross-lamination, } \\
\text { horizontal stratification, \& } \\
\text { ripples on bedding surfaces. } \\
\text { Up to } 1.5 \text { m thick shale } \\
\text { units with no sedimentary } \\
\text { structures. }\end{array}$ & $\begin{array}{l}\text { Isolated } \\
\text { brachiopods, } \\
\text { bivalves, and plant } \\
\text { debris occur } \\
\text { primarily in siltstone } \\
\text { beds. Vertical and } \\
\text { horizontal burrows } \\
\text { on sandstone } \\
\text { bedding surfaces. } \\
\text { Common } \\
\text { bioturbation. }\end{array}$ \\
\hline
\end{tabular}

Table 1. Summary of facies characteristics for the Barrier Island and Marine-Influenced Outer Lagoon. 


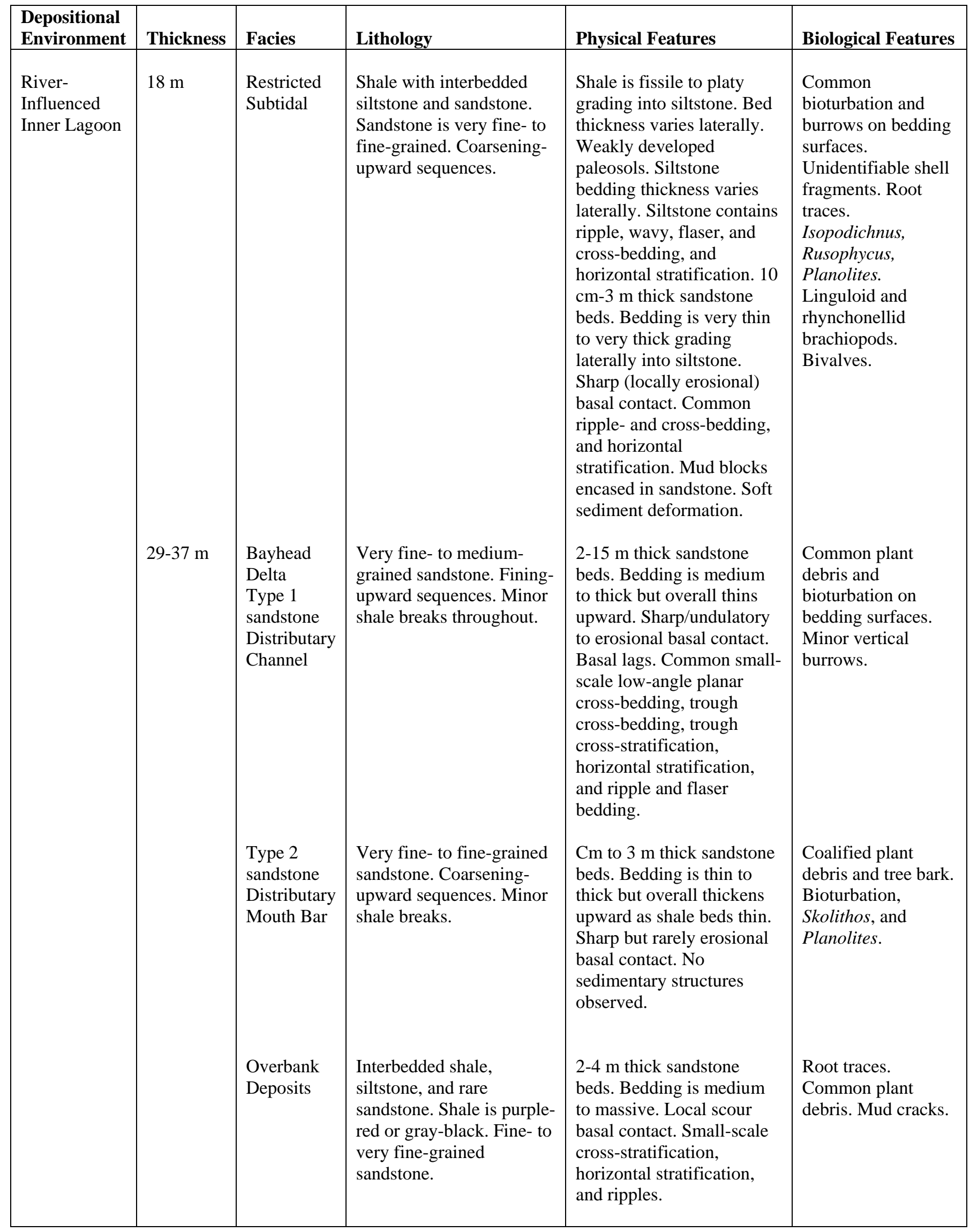

Table 2. Summary of facies characteristics for the River-Influenced Inner Lagoon. 


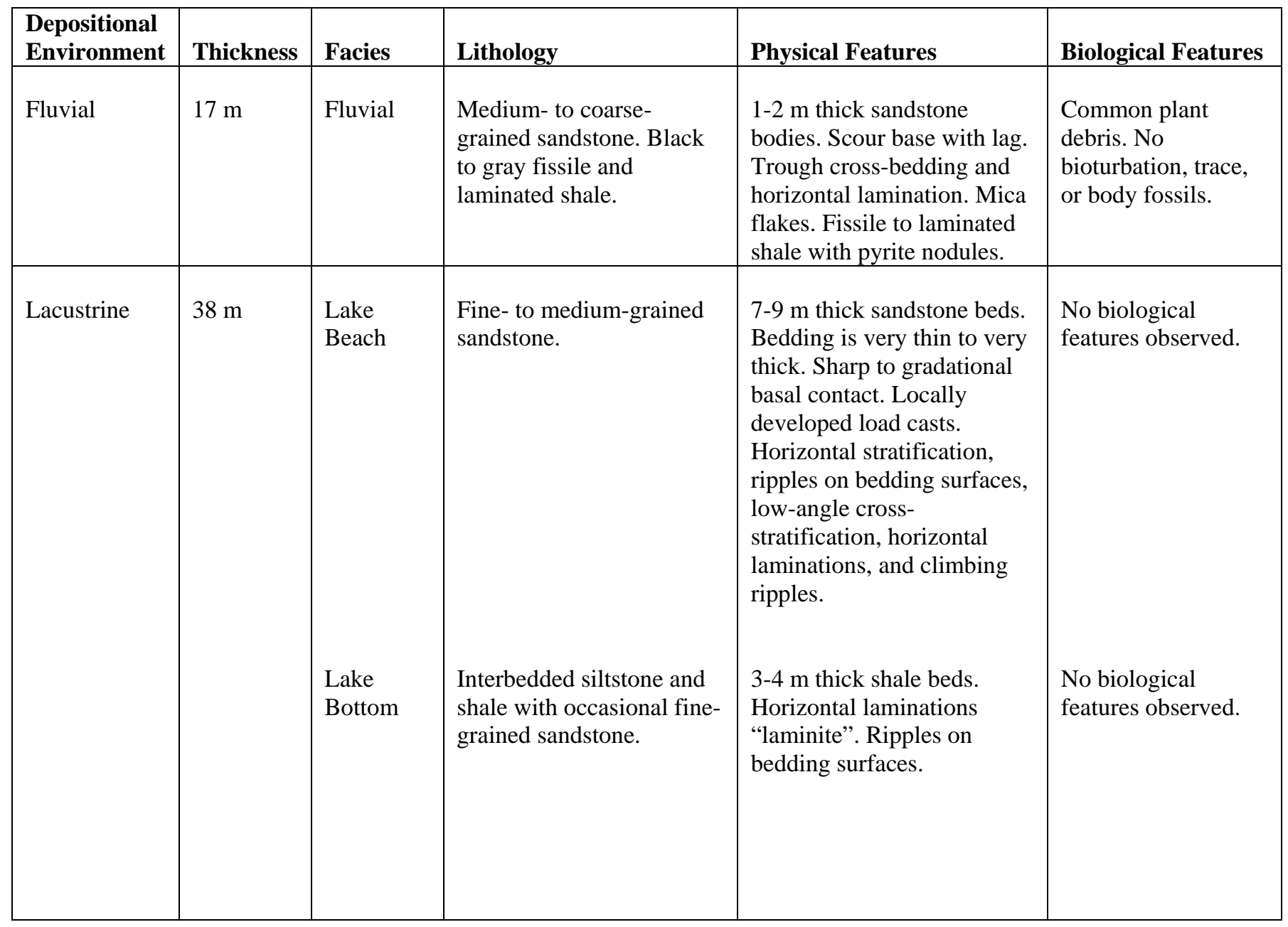

Table 3. Summary of facies characteristics for the Fluvial and Lacustrine environments. 


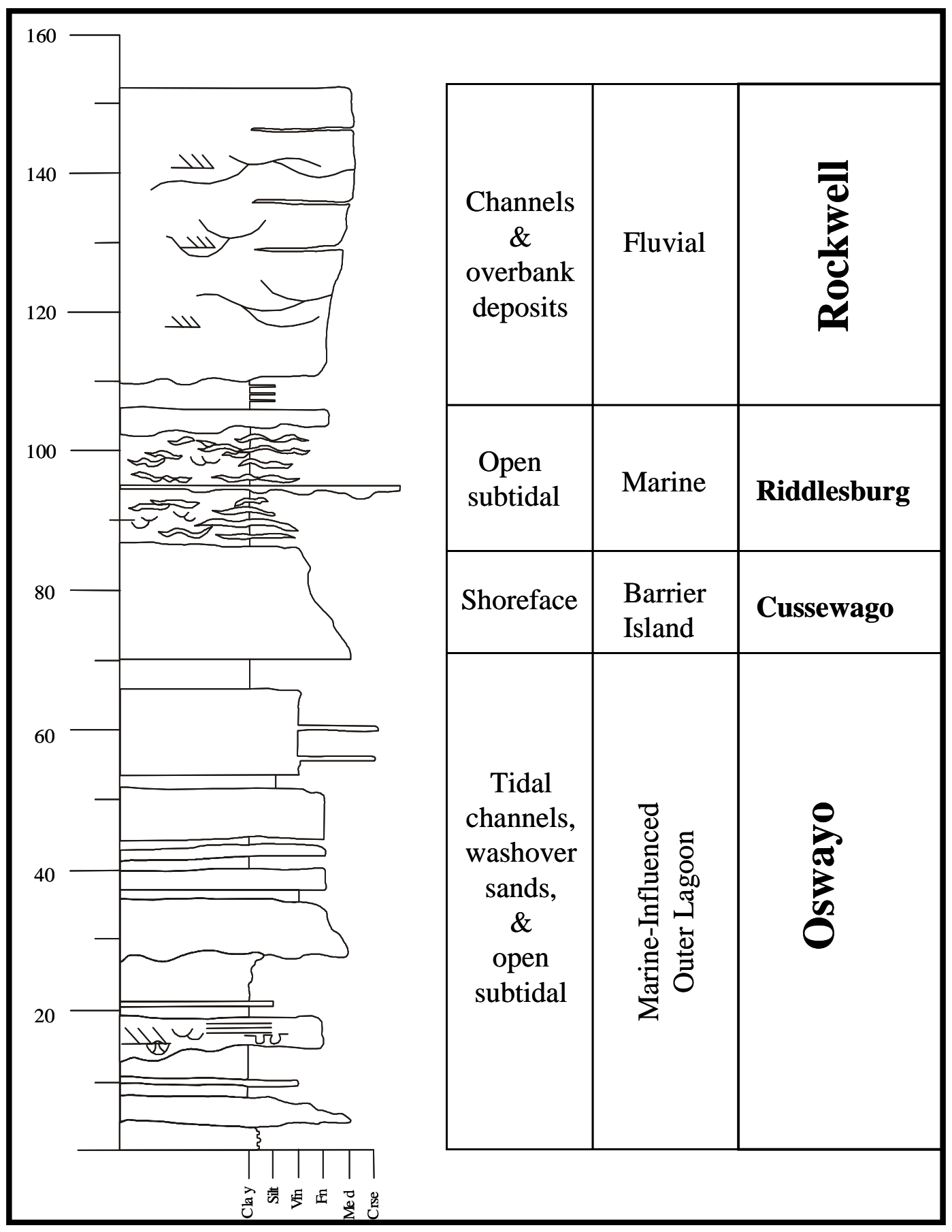

Figure 10. Rowlesburg stratigraphic column. Section starts above Hampshire red-beds. Section stops below the base of the overlying Greenbrier Limestone. 


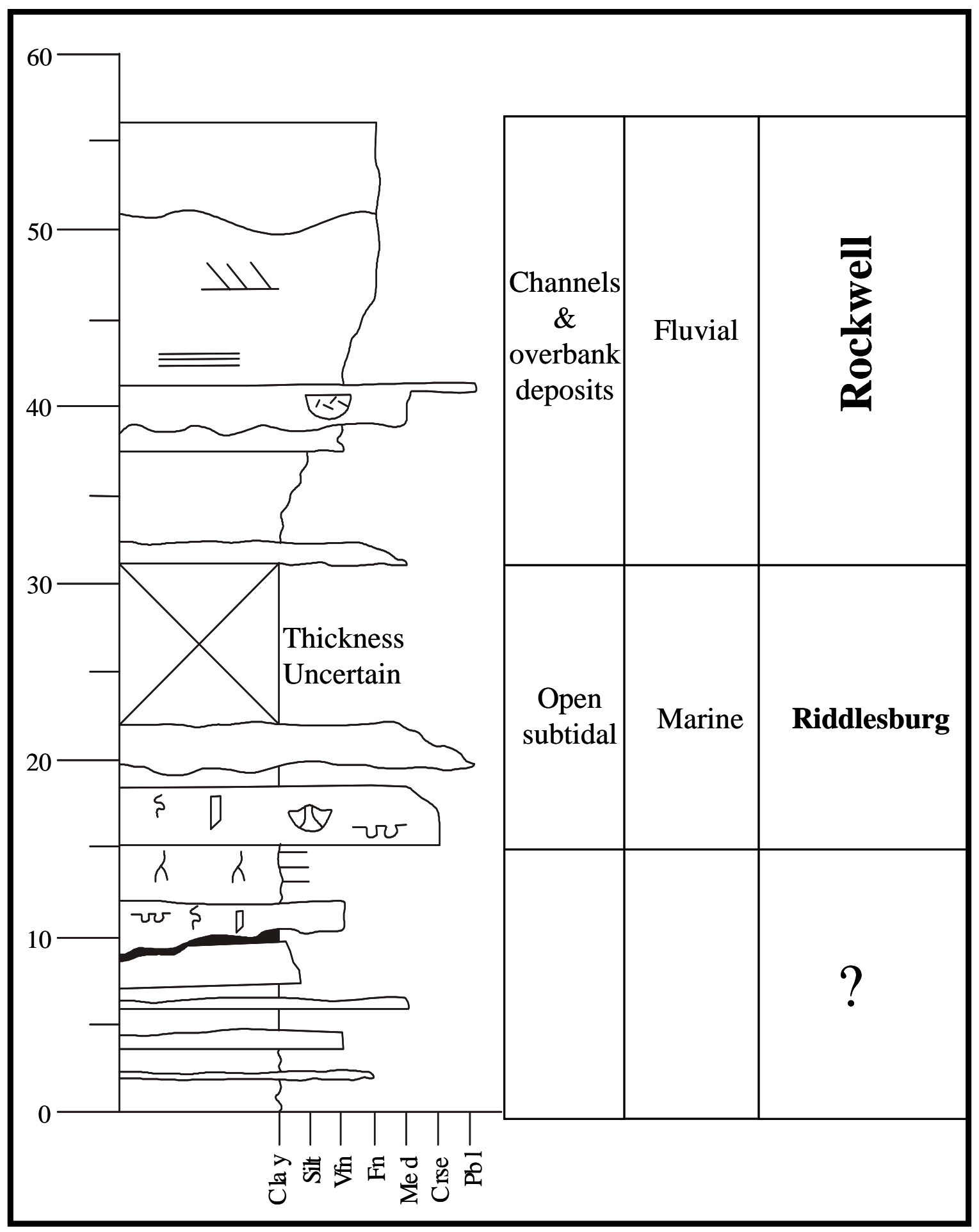

Figure 11. Keysers Ridge stratigraphic column. Neither the underlying nor overlying Formations are present at this outcrop. 


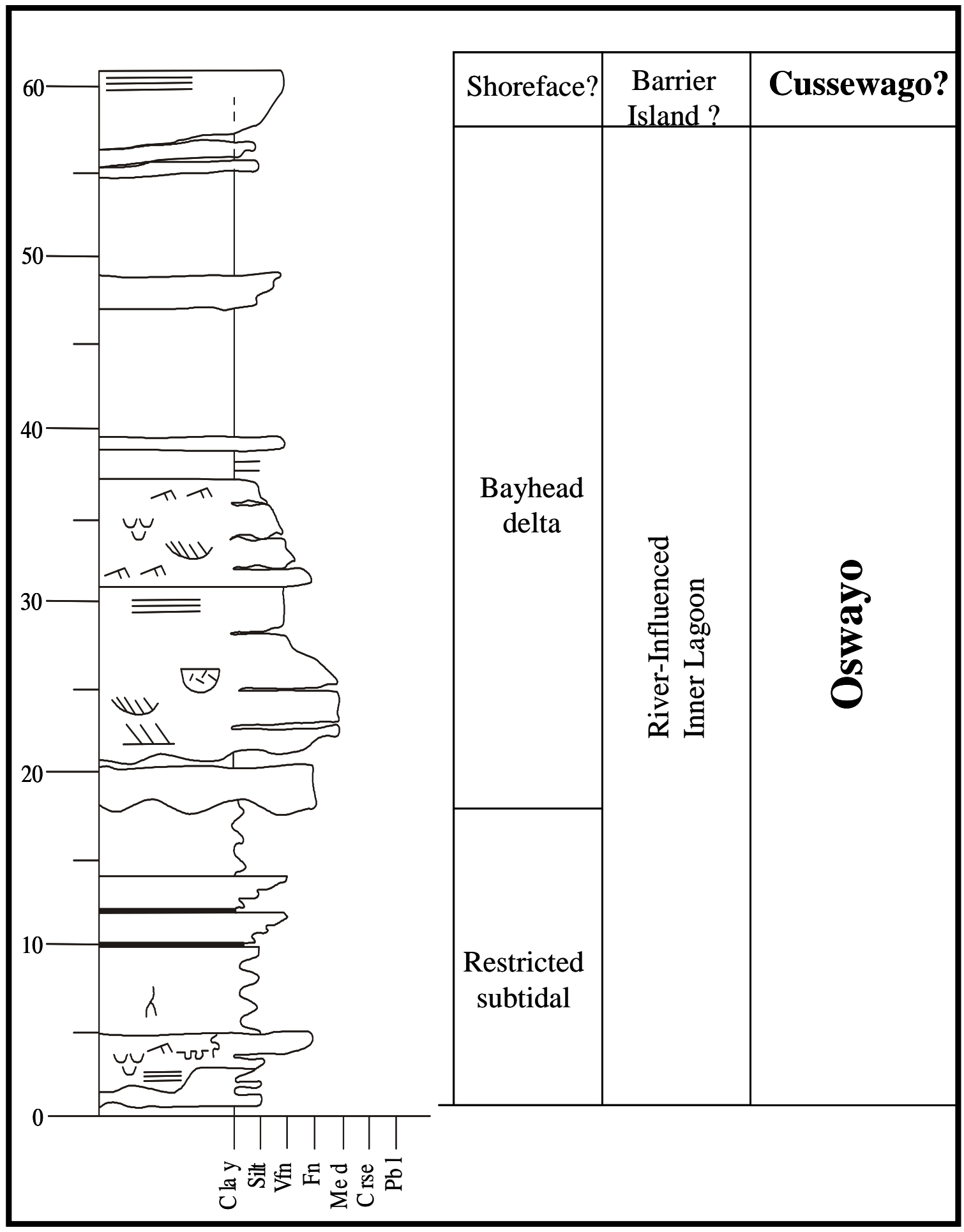

Figure 12. Finzel stratigraphic column. Sections starts at top of Hampshire red-beds. 


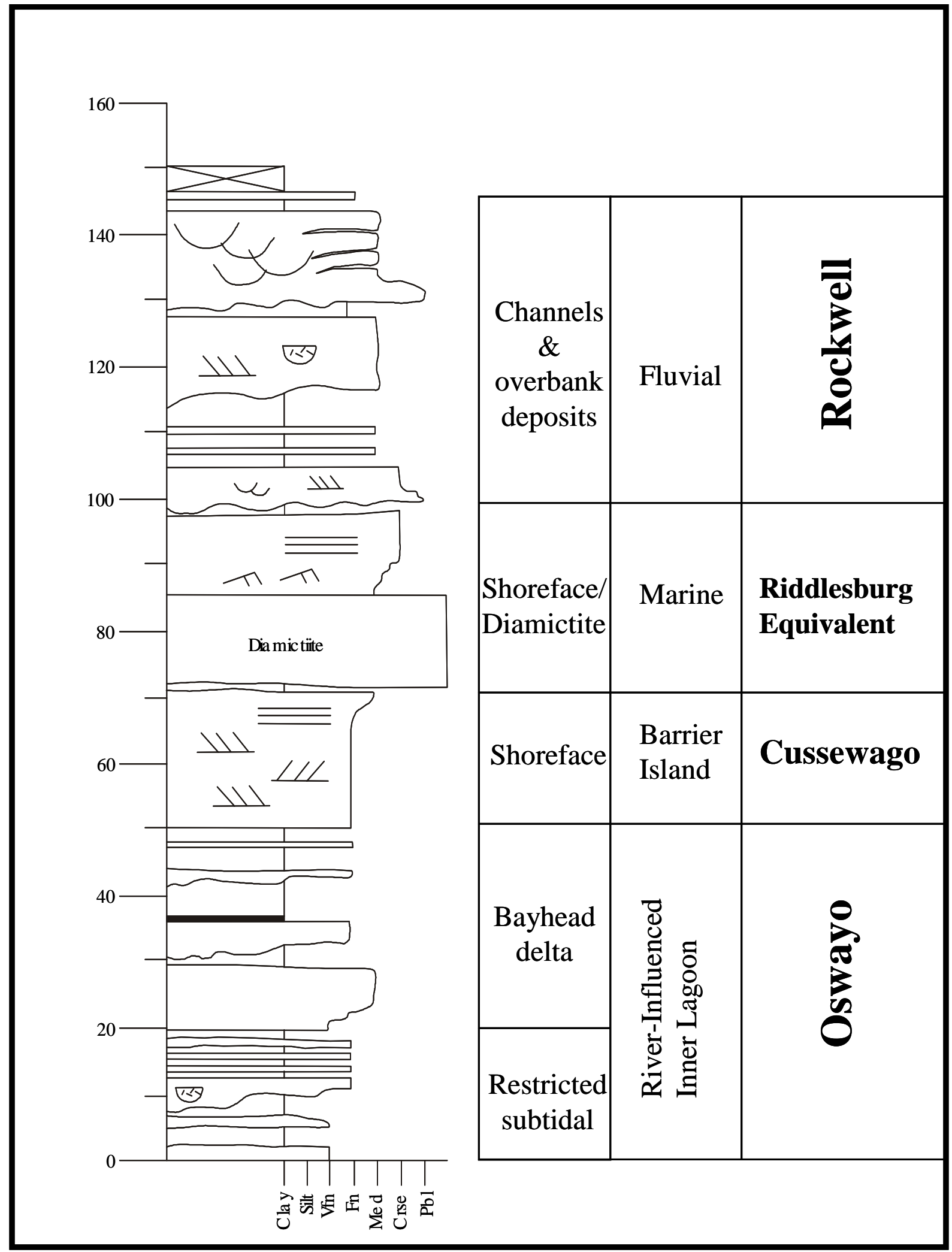

Figure 13. LaVale stratigraphic column. Section starts at Hampshire redbeds. 


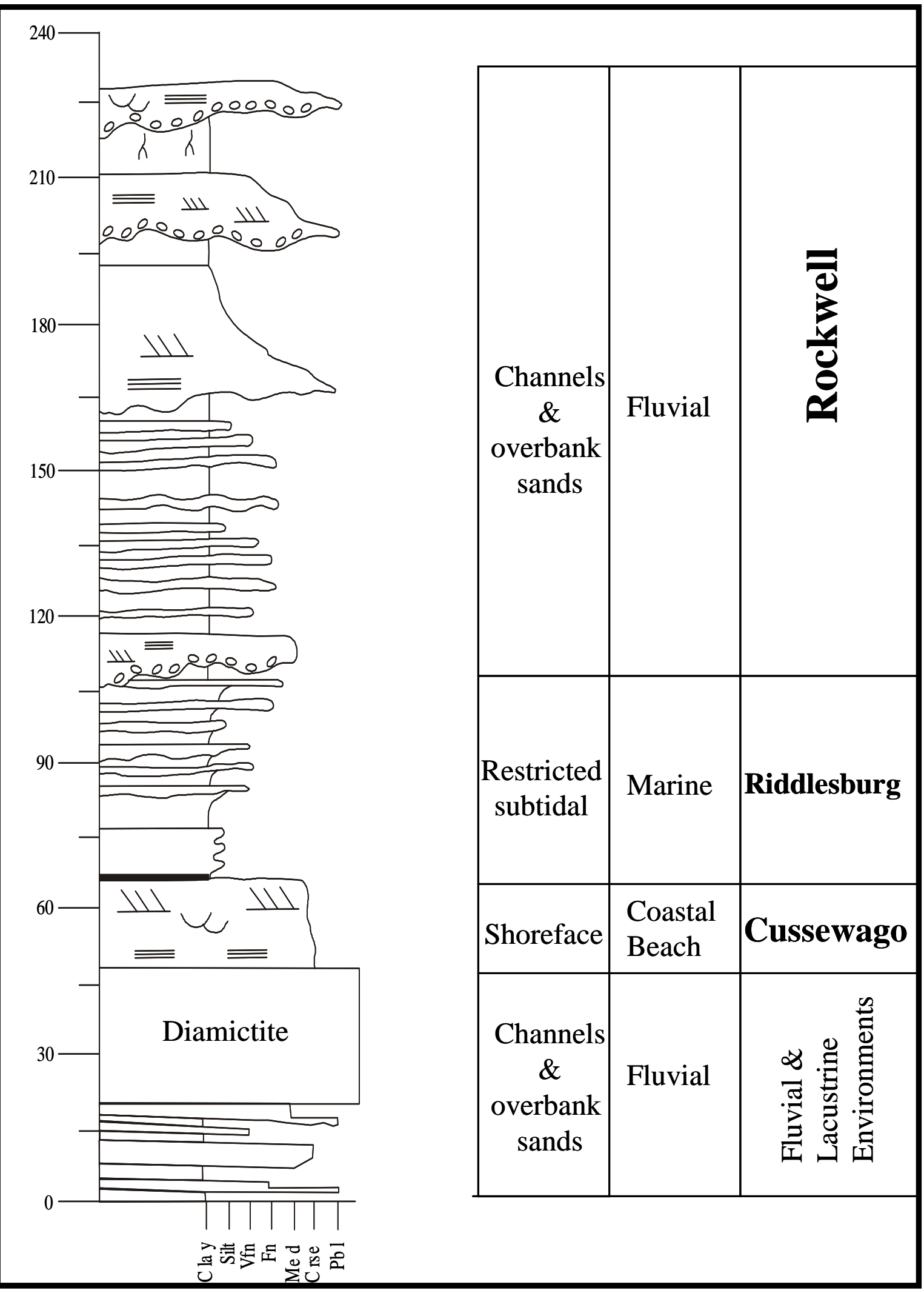

Figure 14. Sideling Hill stratigraphic column. Section starts at Hampshire red-beds. Section ends at base of Purslane Formation. 


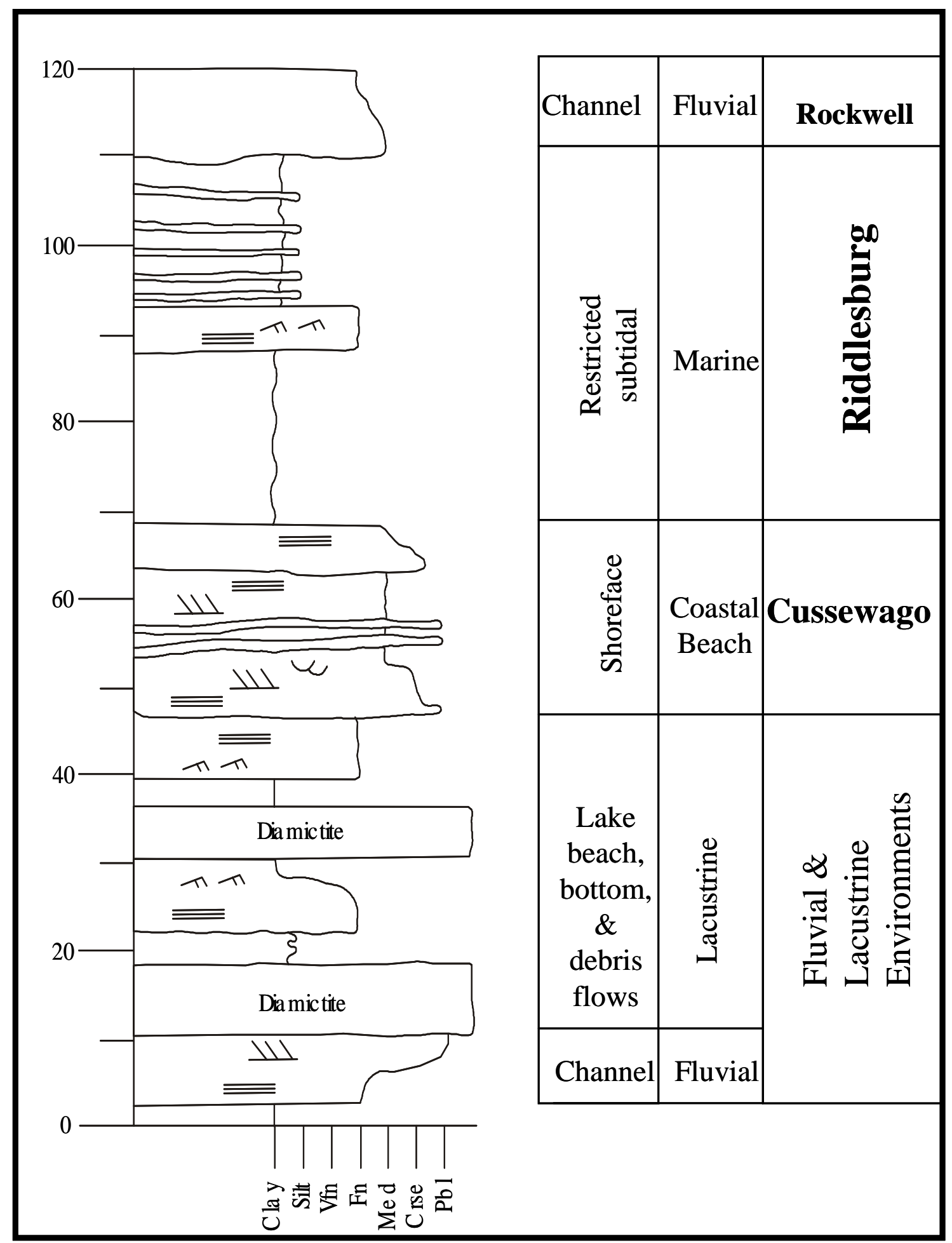

Figure 15. Crystal Spring stratigraphic column. Section starts at top of Hampshire red-beds. 


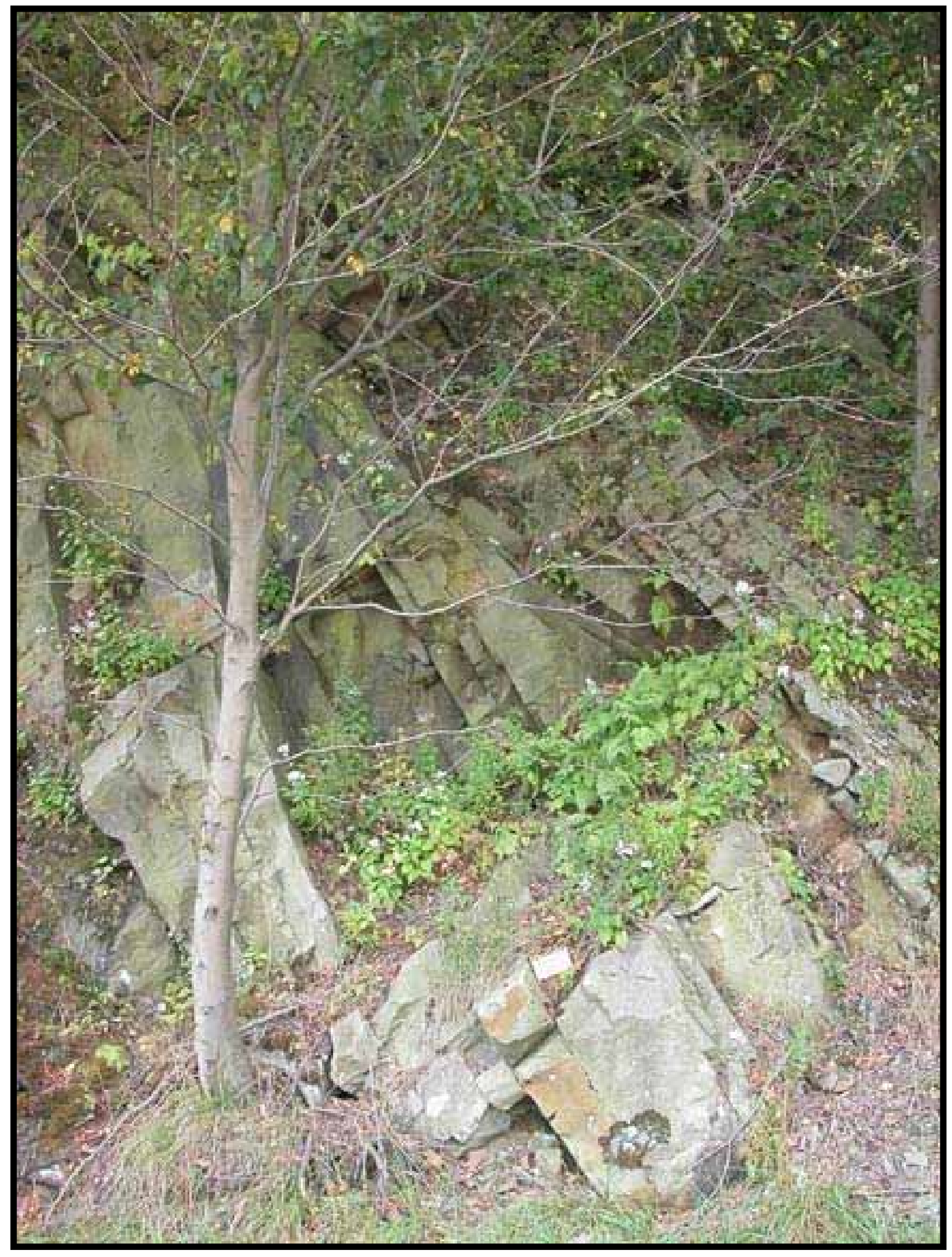

Figure 16. Photo ID \#1101: Photo shows the wedge-shaped beds in Unit 21 at LaVale. 


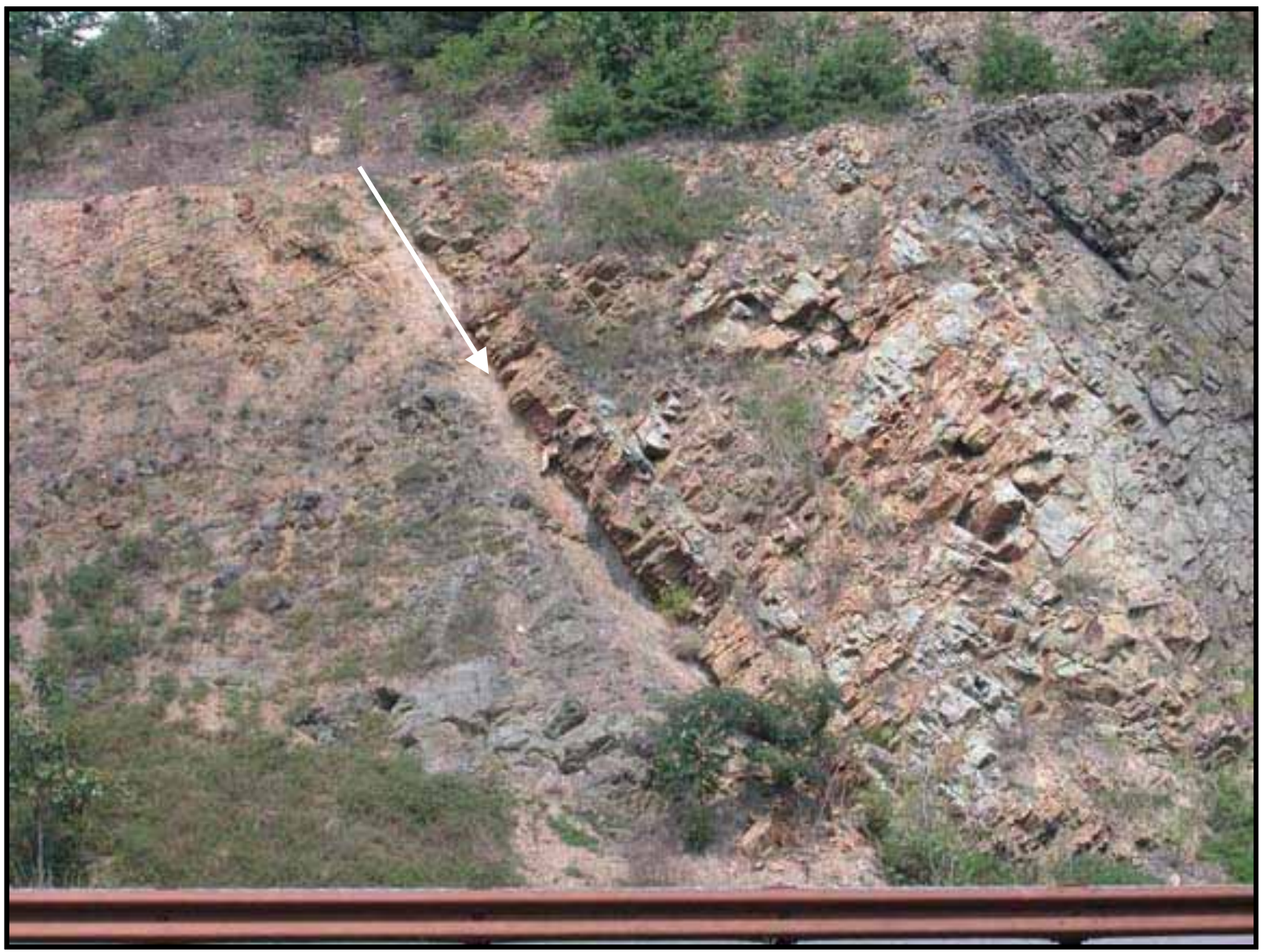

Figure 17. Photo ID \#1118: Photo shows the contact (wave ravinement surface) indicated by the white arrow of Unit 2 with the underlying diamictite at Sideling Hill. 
stratification to trough cross-stratification to low-angle planar cross-stratification. No trace or body fossils were observed in this study, but Bjerstedt (1986) identified Skolithos.

At the Crystal Spring outcrop (Units $10 \& 11$ ), the sandstone body exhibits a finingupward sequence from coarse- to medium-grained. The sandstone is $16 \mathrm{~m}$ thick. At the base is a 1.2-m-thick granule- to pebble-size quartz conglomerate (Figs. 18 and 19), and interbedded with the overlying sandstone are additional beds of quartz pebbles and granules (Fig.20). These conglomerates have a scour base (Fig. 21), trough cross-stratification (Fig. 22), and range in thickness from 10-60 cm (Fig. 23). Bedding in the sandstone ranges from medium to very thick, and some beds are wedge-shaped. At the base and near the middle of the unit are sharp erosional surfaces with as much as $1 \mathrm{~m}$ of scour. Sedimentary structures include horizontal stratification, low-angle planar cross-stratification, trough cross-stratification, and tool marks (Fig. 24).

Interpretation - This tabular sandstone of the middle Rockwell, ranging from 16 to 20 $\mathrm{m}$ thick, is interpreted as the transgressive shoreface of a barrier island. The basal contact is often erosive (Fig. 25) and locally has a pebble lag. Such an erosional surface comprises a waveravinement surface (Figs. 26 and 17; Swift, 1968) formed during rising sea level and commonly overlain by shoreface sand and shelf mud. Wave-ravinement surfaces are typically paved with a thin shell and gravel lag (Fig. 27; Demarest and Kraft, 1987). Above the basal contact the Rockwell sandstone generally fines upward in section and is overlain by finer-grained (Fig. 28) deeper-marine sediments of an open- to restricted-subtidal facies (Riddlesburg Member). Some sandstone contains discontinuous wedge-shaped beds and internal scoured surfaces (with pebble lags and shale clasts eroded from shale interbeds), indicating a cyclicity of erosion and deposition related to changing wave conditions or storms. Common sedimentary structures observed in this study include horizontal stratification (deposited from suspension by storms), 


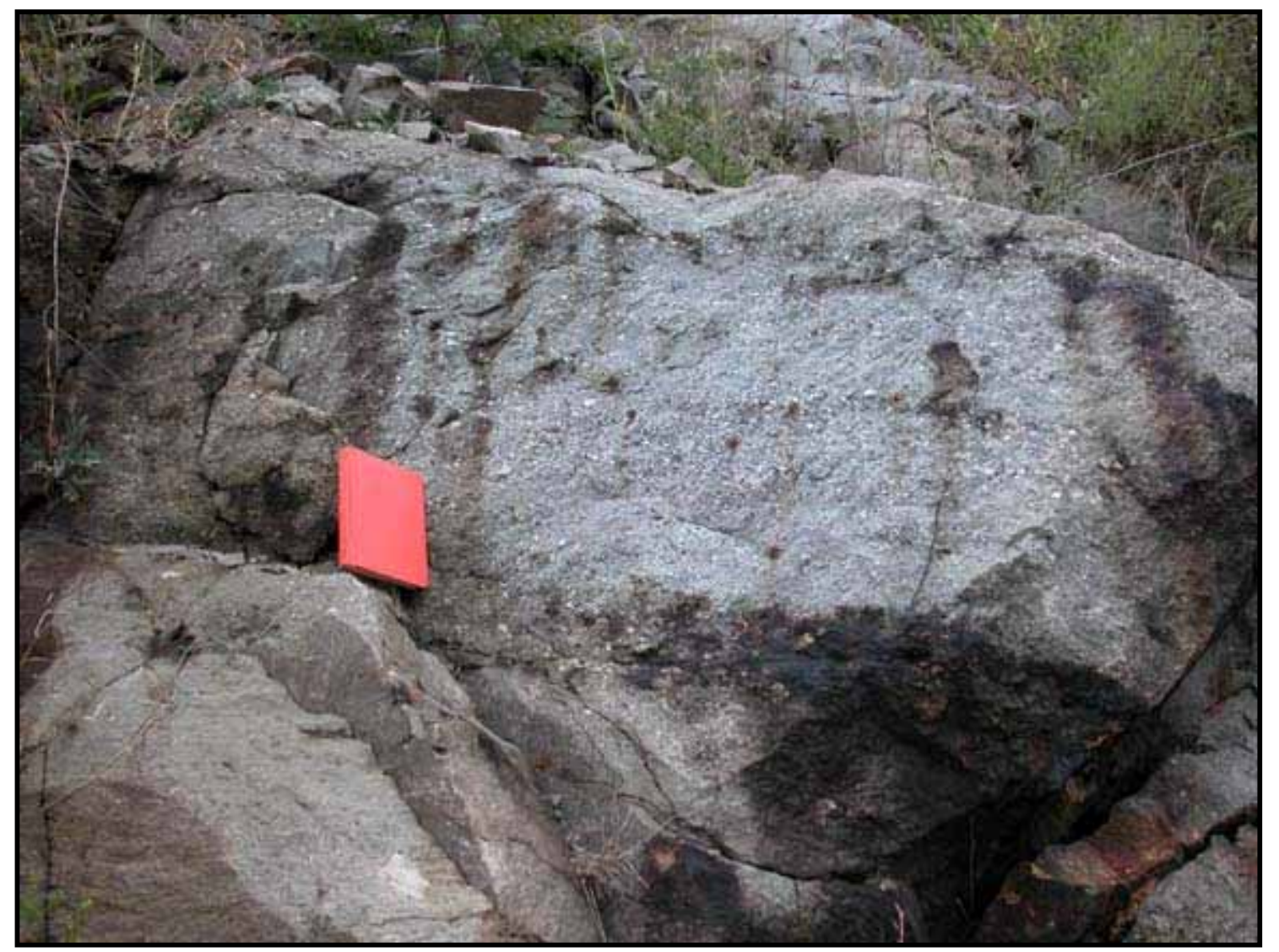

Figure 18. Photo ID \#1138: Photo shows granule- to pebble-size quartz conglomerate in the base of Unit 10 at Crystal Spring. 


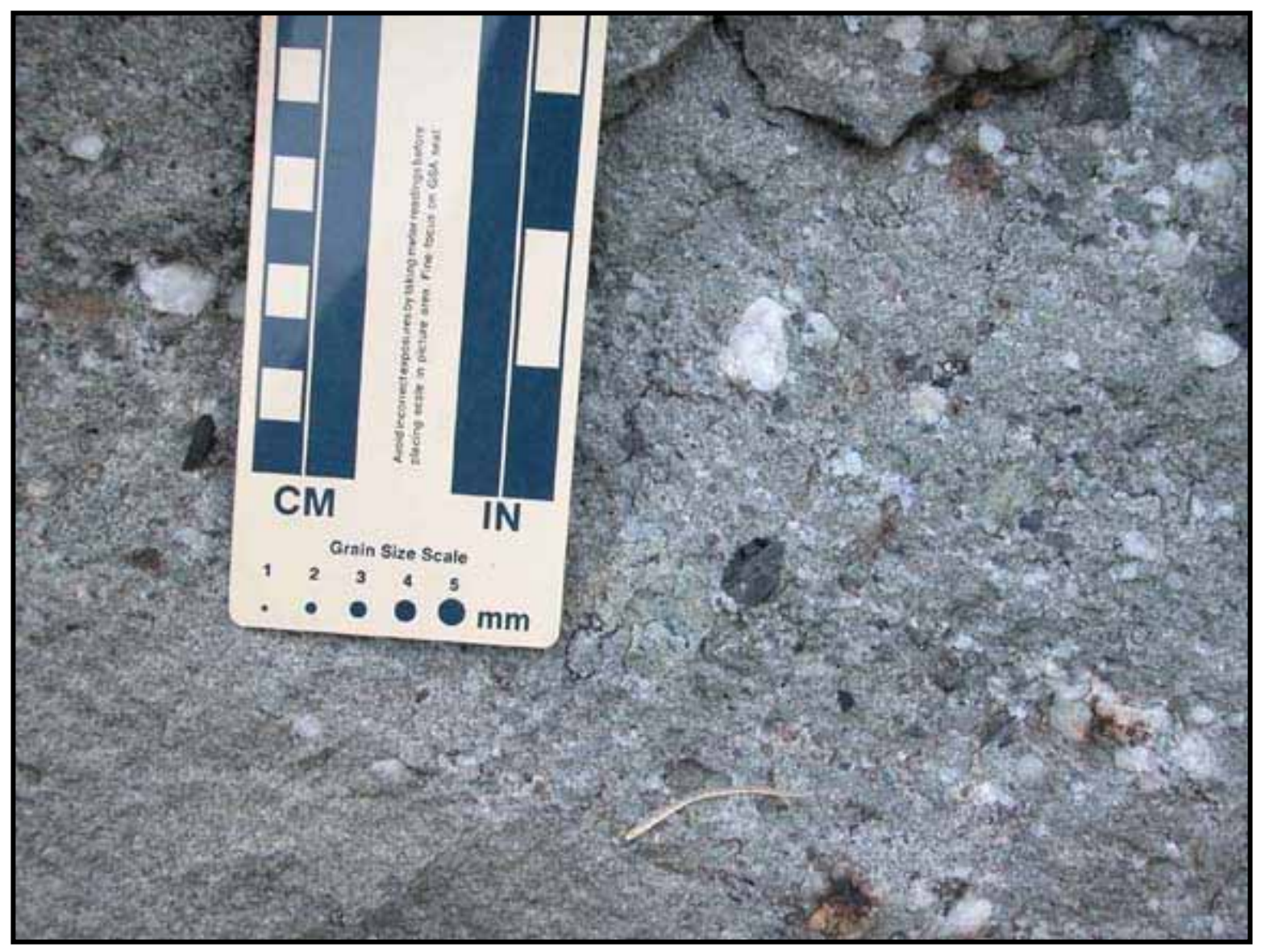

Figure 19. Photo ID \#1139: Photo shows the pebbles in Unit 10 at Crystal Spring with a grain size scale. 


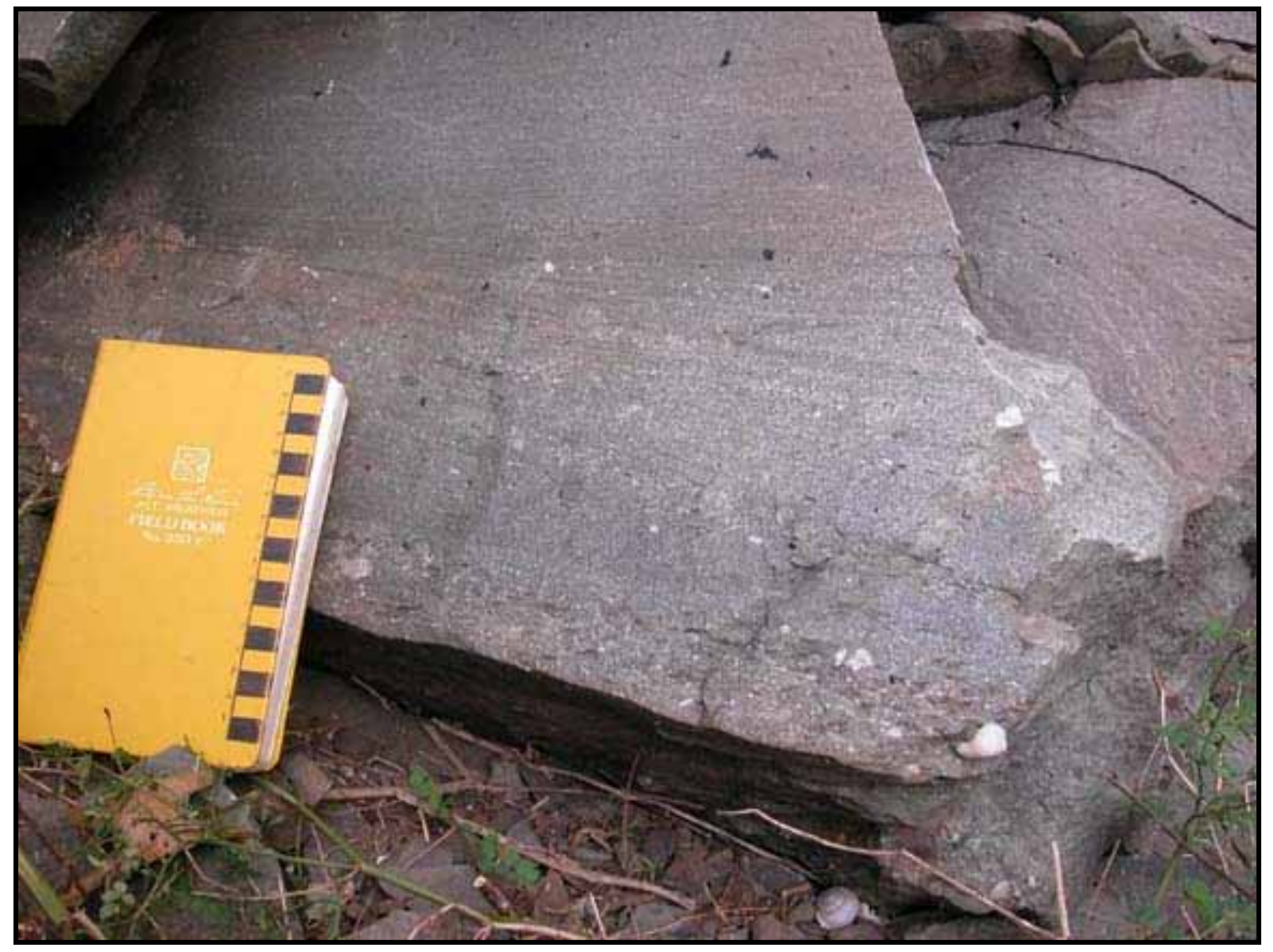

Figure 20. Photo ID \#0658: Photo shows additional beds of quartz pebble layers in Unit 11 at Crystal Spring. 


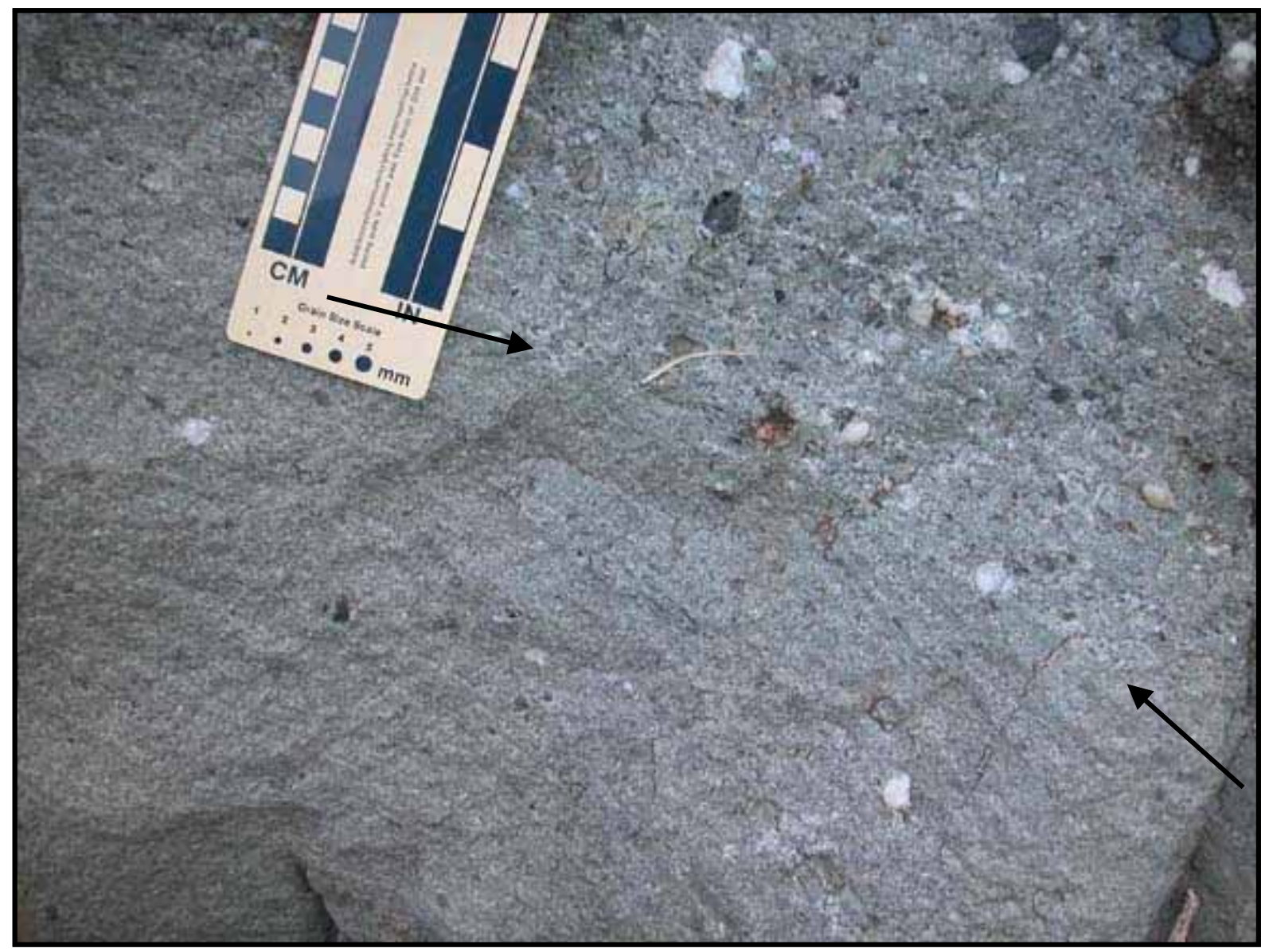

Figure 21. Photo ID \#1140: Photo shows scour surface (indicated by arrows) of conglomerate layer in Unit 10 at Crystal Spring. 


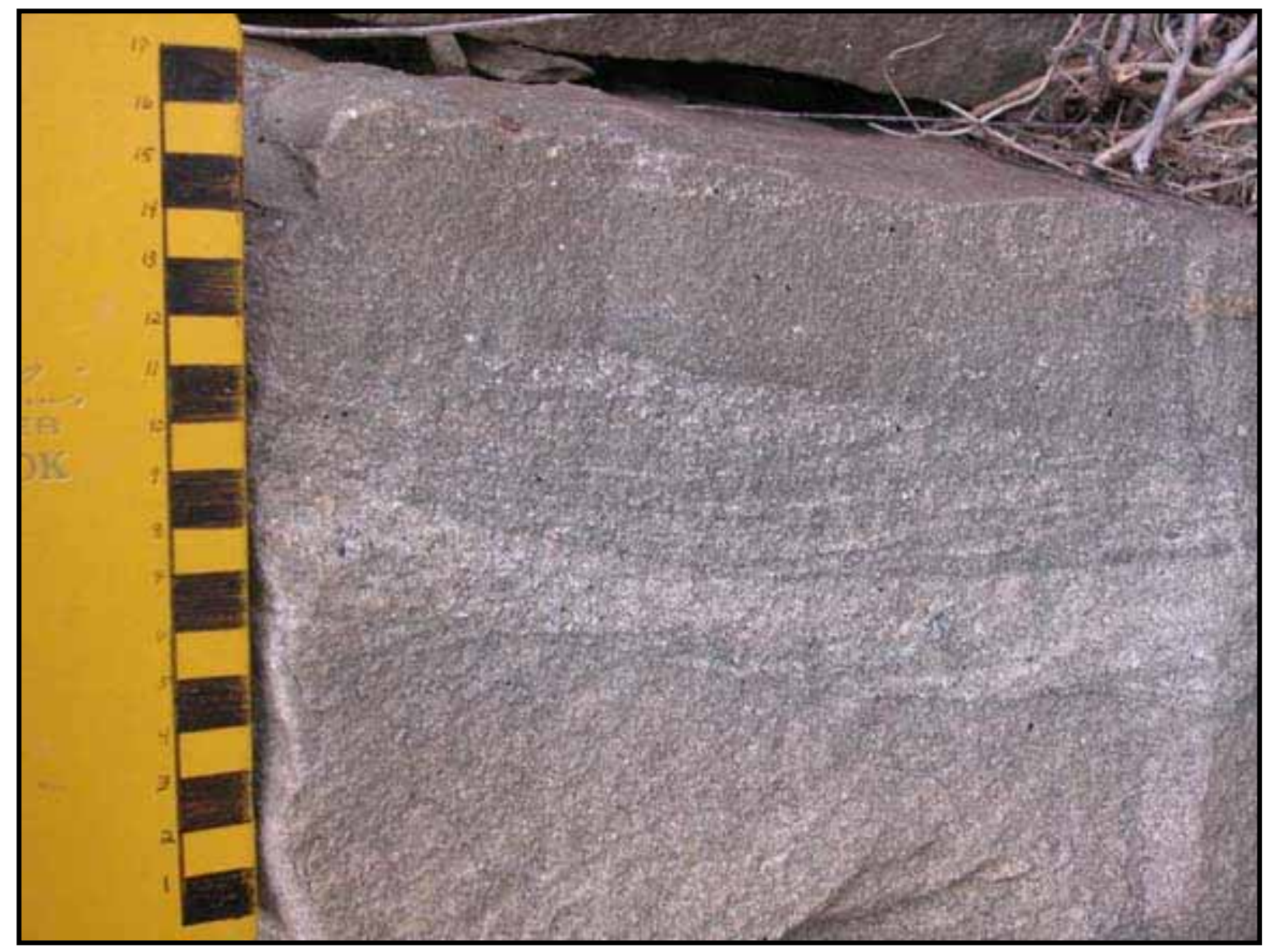

Figure 22. Photo ID \#0657: Photo shows trough cross-stratification in Unit 10 at Crystal Spring. 


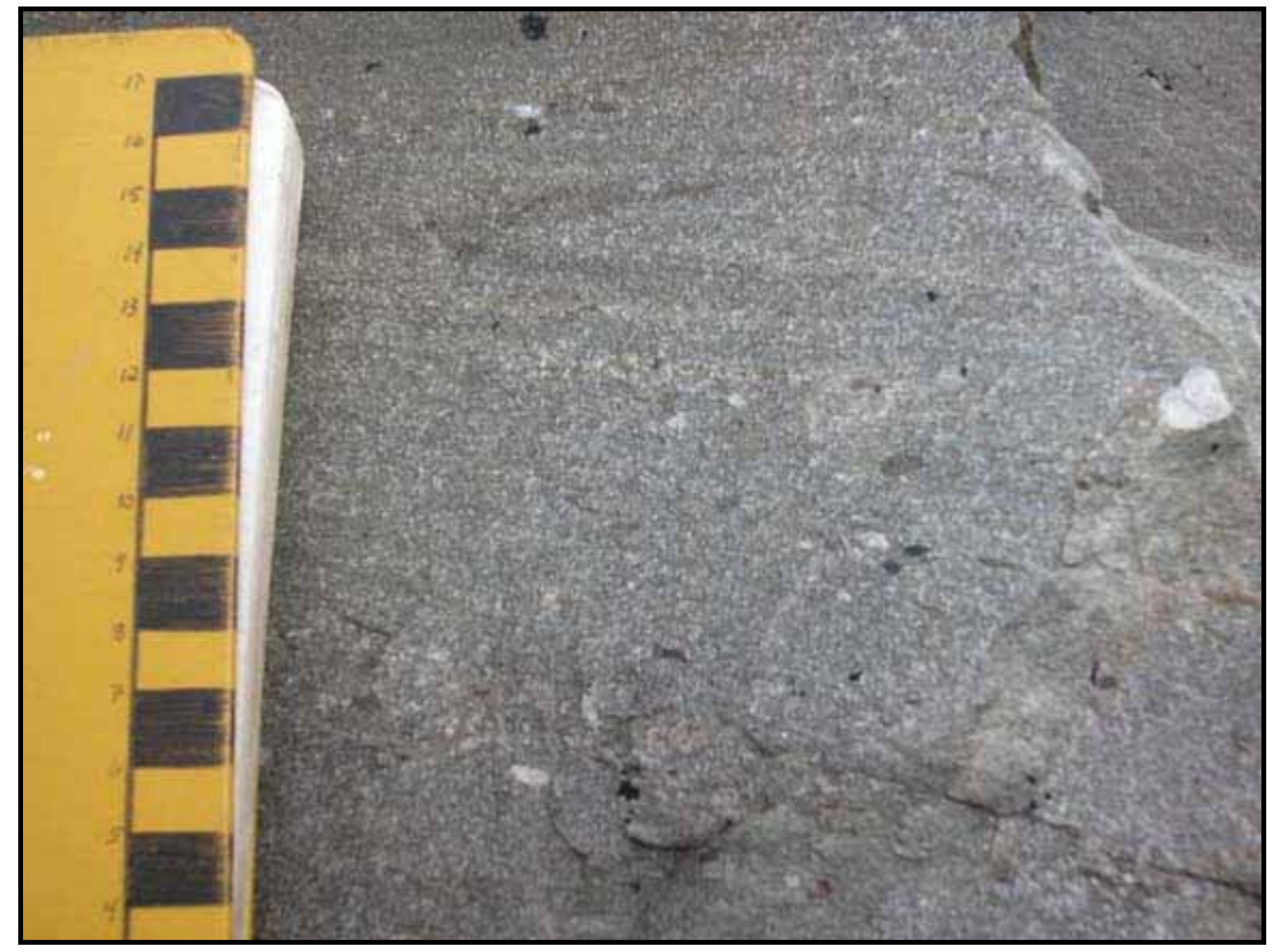

Figure 23. Photo ID \#0659: Photo shows range of thickness of trough crossstratification in Unit 11 at Crystal Spring. Notebook has cm scale. 


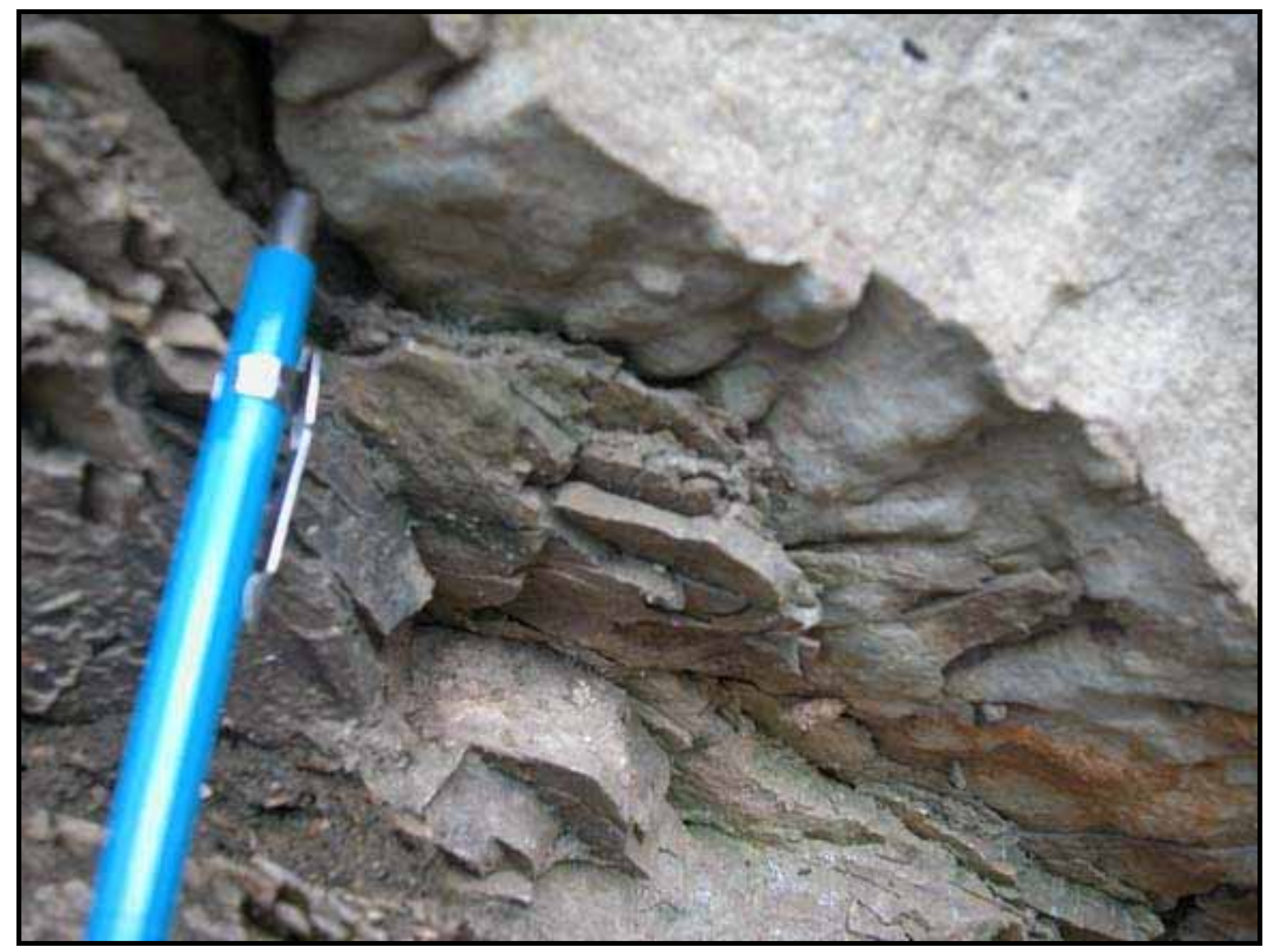

Figure 24. Photo ID \#0660: Photo shows tool marks at the base of Unit 11 at Crystal Spring. 


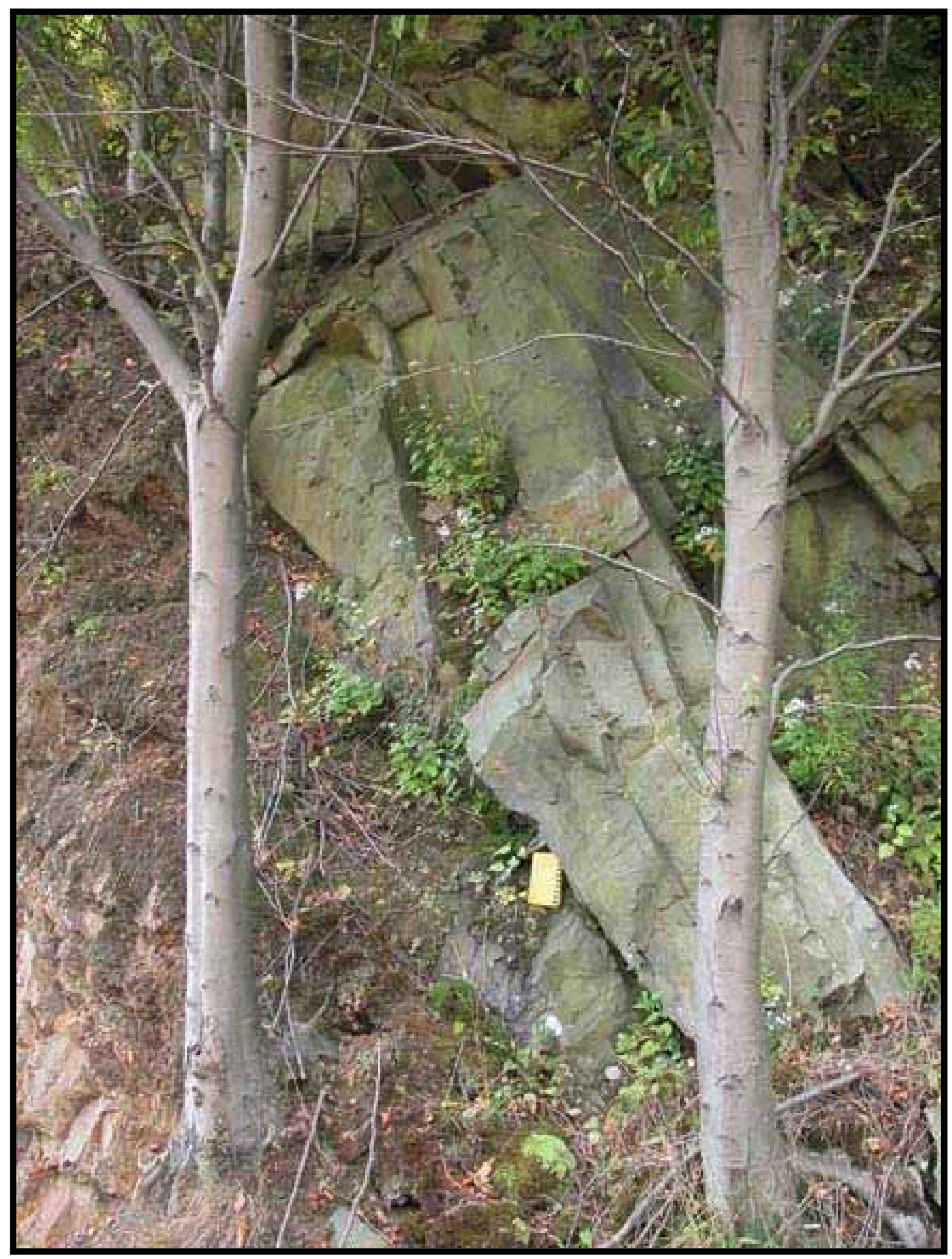

Figure 25. Photo ID \#1099: Photo shows erosive base of barrier island sandstone at the base of Unit 21 at LaVale overlain by wedge-shaped bedding. 


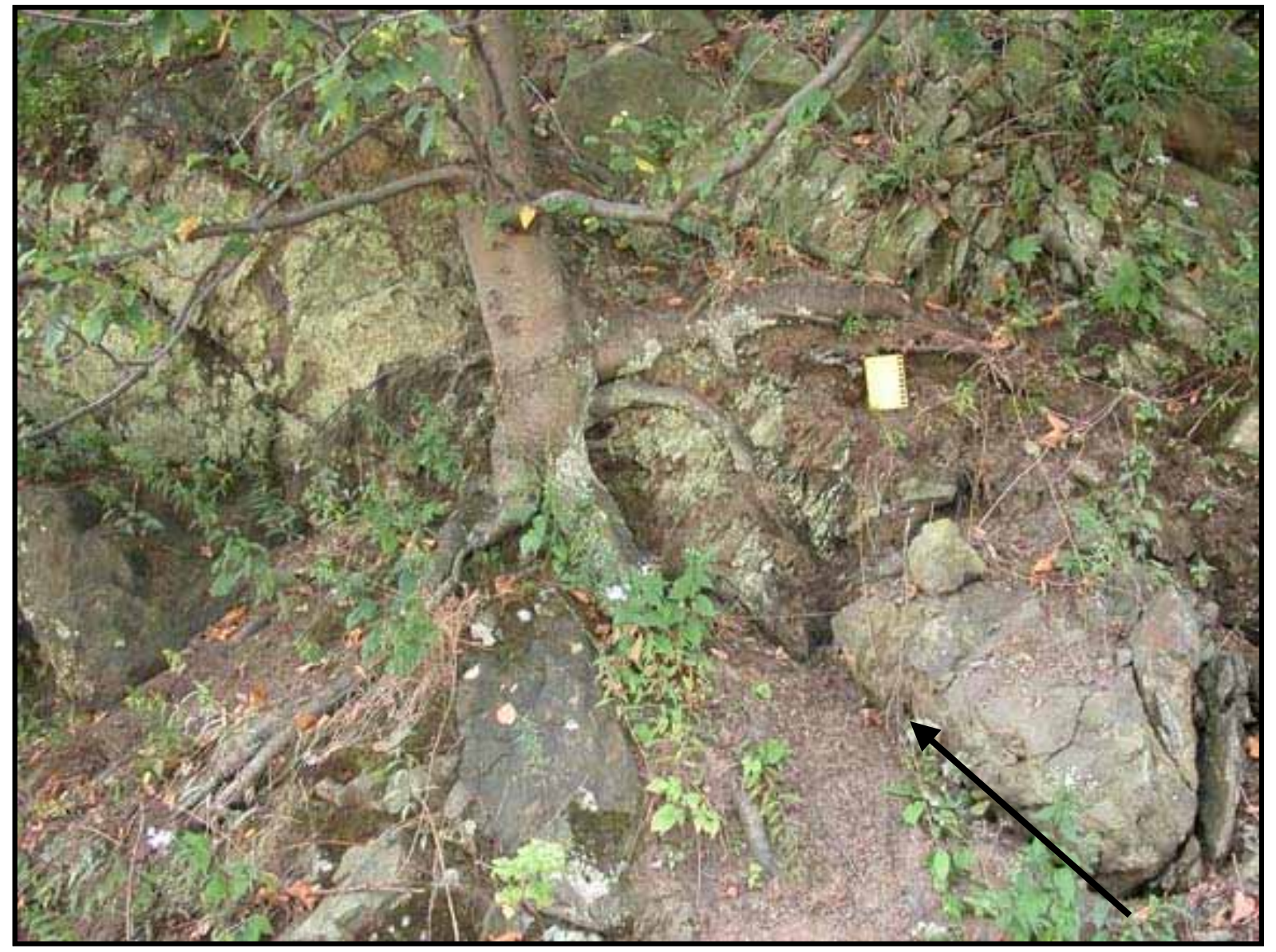

Figure 26. Photo ID \#1104: Photo shows wave ravinement surface (indicated by arrow) at the base of Unit 24A at LaVale. Erosion into underlying diamictite is more obvious in outcrop. 


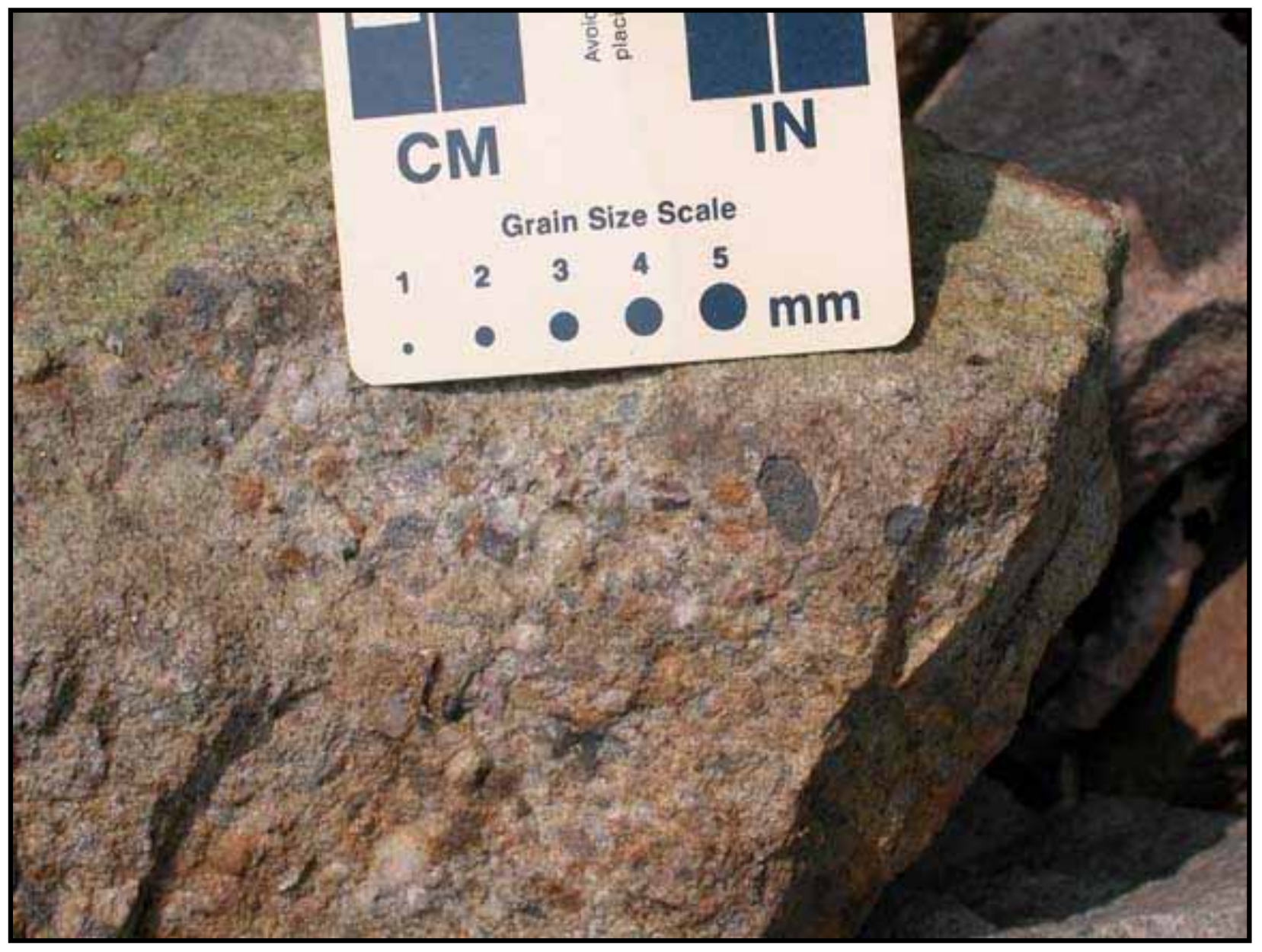

Figure 27. Photo ID \#1113: Photo shows a thin gravel lag with grain size scale in the wave ravinement surface at the base of Unit 24A at LaVale. 


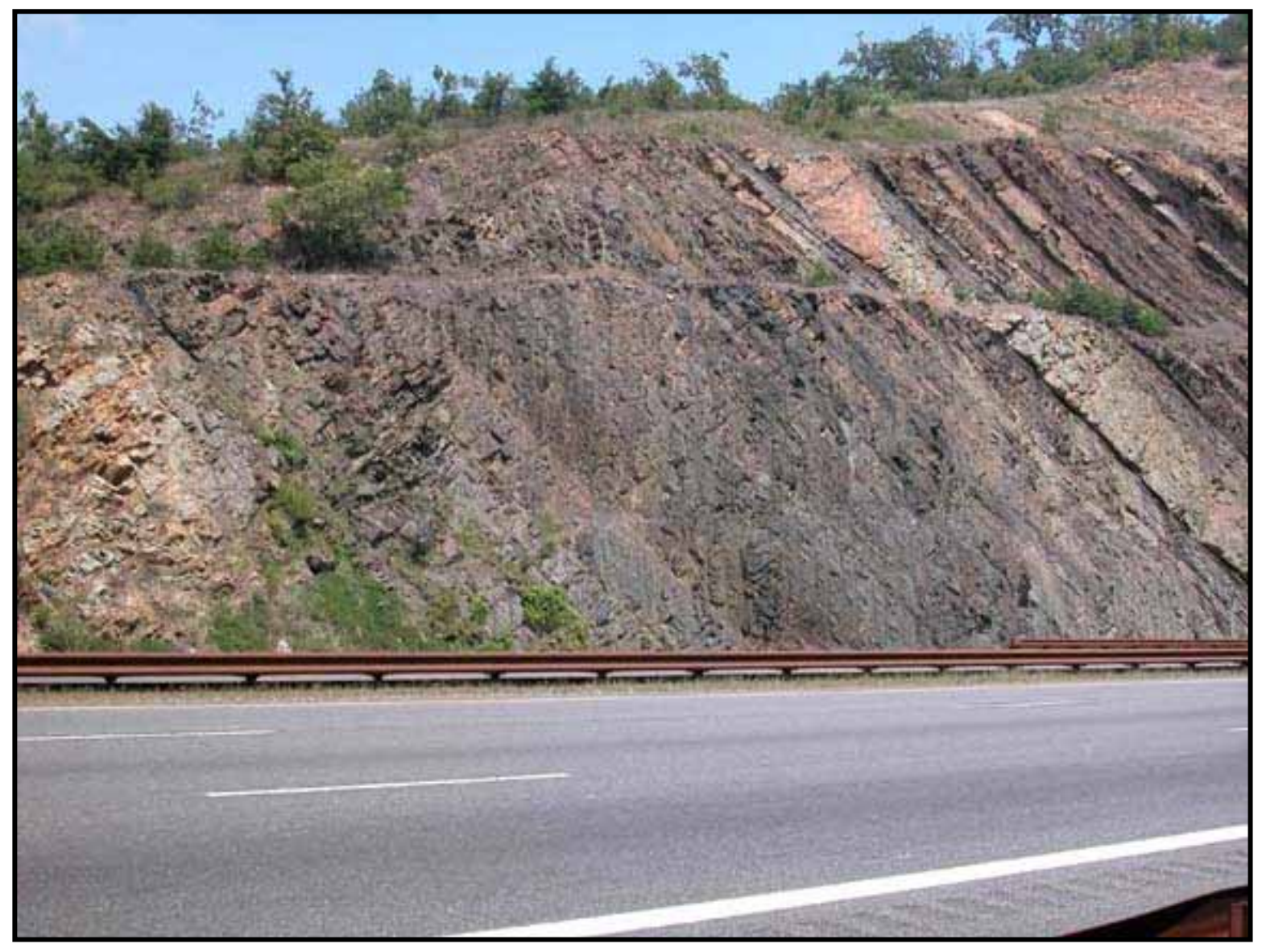

Figure 28. Photo ID \#1120: Photo shows dark gray to purple colored shale above the basal sandstone and below the scour based sandstone bed. This shale package is the Riddlesburg at Sideling Hill. Up section is to the upper right in the photo. 
planar and trough cross-stratification (sand waves and dunes), and bidirectional crossstratification (Fig. 29; dipping both landward and seaward). Sediment transport on the shoreface was dominated by bi-directional, shore-normal oscillatory wave motion. Trough crossstratification formed by the migration of subaqueous dunes and megaripples (McCubbin, 1981). From west to east in the study area, grain size increases, shale interbeds decrease, and the content of quartz pebbles increase. Likewise, trace fossil abundance decreases as the shoreline transgressed landward toward the sediment source. Castle et al. (2004) interpreted a similar fineto medium-grained sandstone, moderately well sorted, with trough and planar cross-bedding and minor ripples, to be a shoreface deposit. Skolithos, brachiopods, and a diverse trace-fossil assemblage indicate a coastal-marine environment. Bjerstedt (1987) interpreted the ichnofossil assemblage as that of an upper-shoreface environment, possibly with tidal channels. Moreover, he described the ideal conditions for Skolithos as: abundant suspended food, nearly continuous water motion, and unstable sandy substrate.

All of the outcrops in this study, with the exception of Finzel, definitely have the barrier island sandstone preserved. However, Finzel may have just the very base of the sandstone preserved in the upper meter of section. Brezinski (1989) claims there are marine mollusks in the upper sandstone at Finzel. This remains to be determined for certain but it is clear the Finzel section is below the barrier island sandstone.

\section{Marine - Influenced Outer Lagoon}

Description - The outer-lagoon facies is characterized by sandstone units 1-8 m thick. These medium- to very fine-grained sandstones occur with siltstone and shale in an overall fining-upward sequence. Bedding ranges from medium to very thick. The basal contact is 


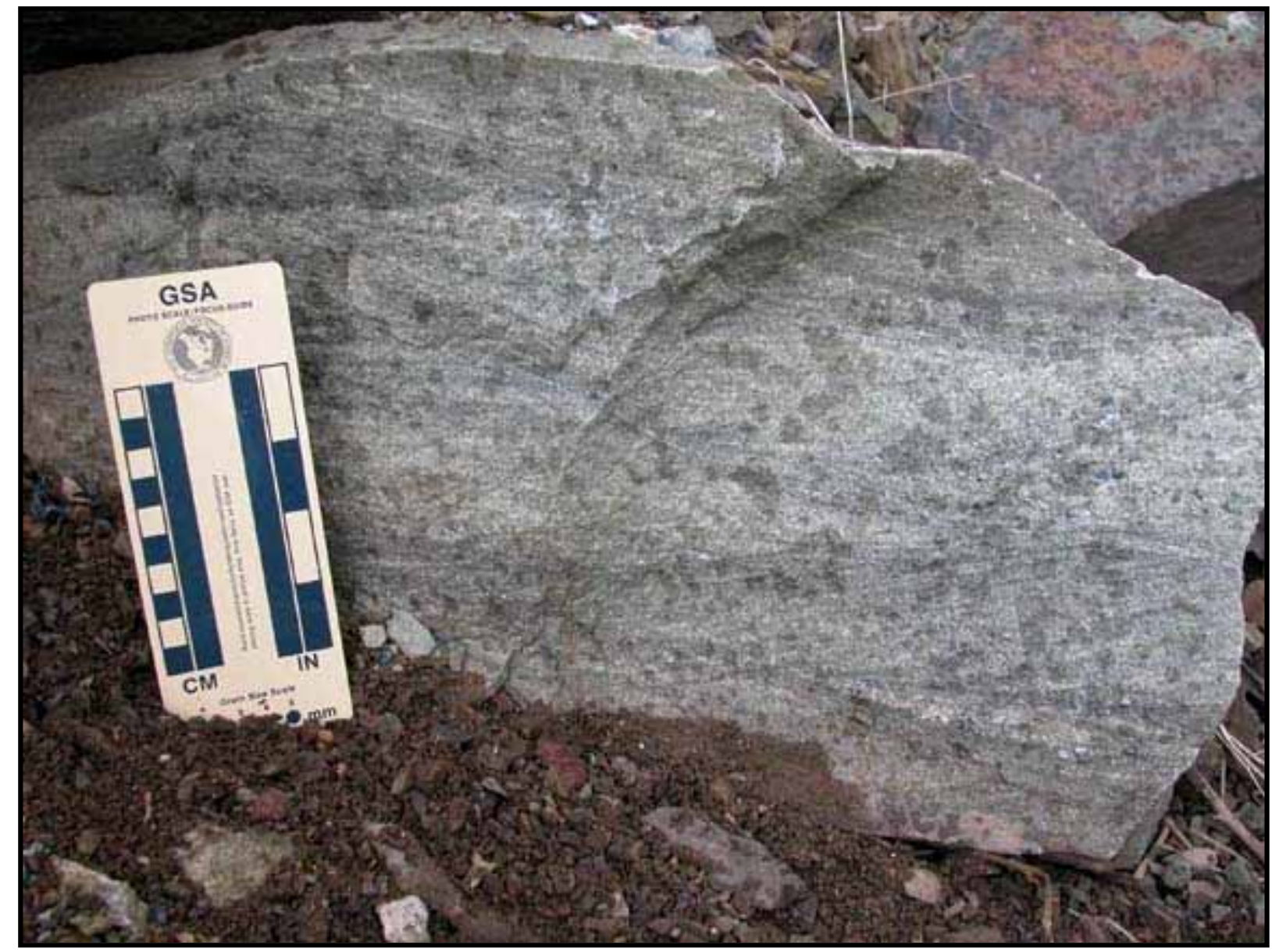

Figure 29. Photo ID \#1141: Photo shows bidirectional cross-stratification in Unit 10 at Crystal Spring. 
always sharp (Figs. 30 and 31), and some show scour of up to 3.4 meters (Fig. 32). The erosional base may contain scattered brachiopod shells or a quartz-pebble conglomerate (Fig. 33). Thin lenses of quartz-pebble conglomerate also occur within some of the sandstones. Horizontal bedding, low-angle inclined bedding (Fig. 34), lamination, large-scale trough and planar crossbedding (Fig. 35), and ripple bedding are the typical sedimentary structures. One sandstone unit exhibits several reactivation surfaces, characterized by sets of cross-bedding separated by a lowangle inclined erosional surface. Another sandstone unit has wedge-shaped beds. Vertical and horizontal burrows (Figs. 36-40) are abundant along upper and lower bedding surfaces, respectively. Bioturbation is also common in many of the sandstones. Bjerstedt (1987) identified brachiopods at Rowlesburg (spiriferids, orbiculoids, linguloids, orthids, and rhynchonellids) as well as crinozoans, bryozoans, and bivalves. Trace fossils identified by Bjerstedt (1987) include: Arenicolites, Arthrophycus, Bifungites, Chondrites, Cruziana, Dimorphichnus, Diplocraterion, Paleophycus, Planolites, Rhizocorallium, Rosselia, Skolithos, and Thalassinoides.

Interbedded with the thick sandstone units are shale, siltstone, and very fine- to finegrained sandstone. Sandstone thickness ranges from $10 \mathrm{~cm}$ to $1 \mathrm{~m}$. Bedding in the sandstone and siltstone is generally thin to medium with some lateral discontinuity. Sandstones typically have small-scale cross-lamination, horizontal stratification, ripples on bedding surfaces, and a sharp basal contact. Shale units, up to 1.5 meters thick, contain no sedimentary structures. One unit at Rowlesburg is calcareous. Isolated brachiopods (Fig. 41) and bivalves are present in the silty beds, and plant debris (Fig. 42) is scattered throughout, but predominately in the silty beds. Vertical and horizontal burrows mainly occur on upper and basal bedding surfaces of the sandstones. 


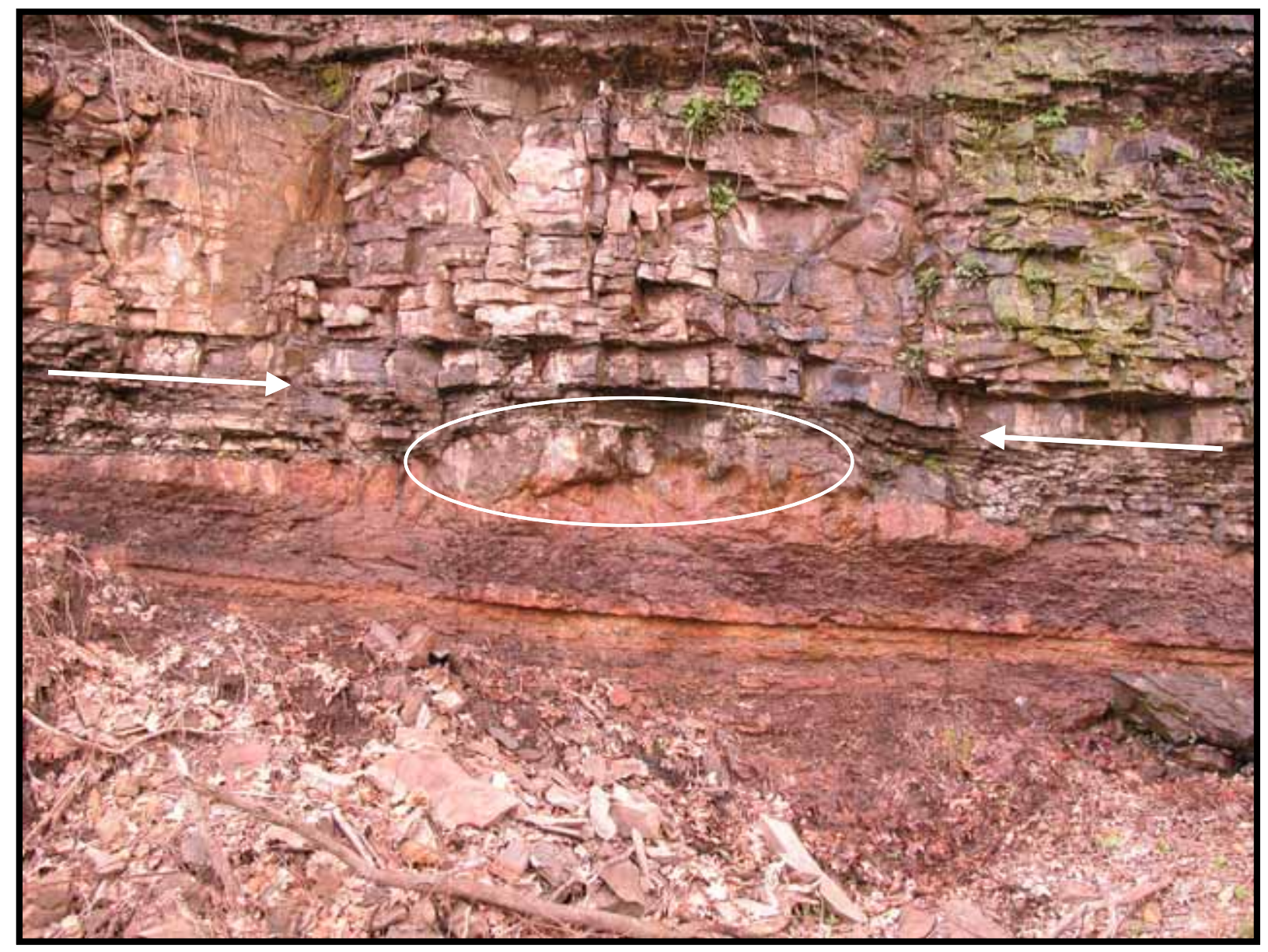

Figure 30. Photo ID \#0572: Photo shows sharp basal contact (indicated by arrows) of Unit 34 at Rowlesburg. Note the large convex "conglomeratic bar" at the base. 


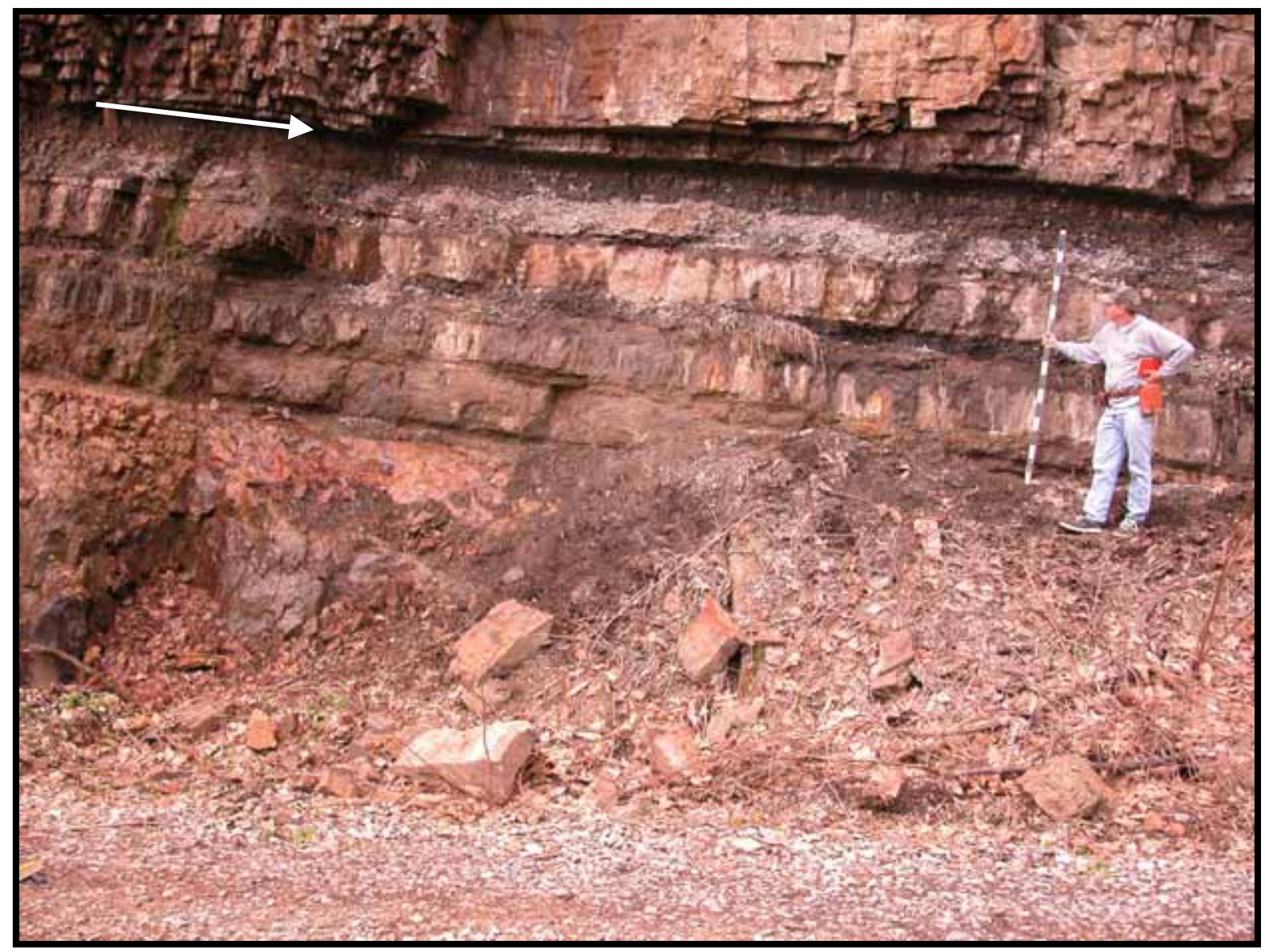

Figure 31. Photo ID \#0569: Photo shows sharp basal contact (indicated by arrow) of Unit 32 at Rowlesburg. 


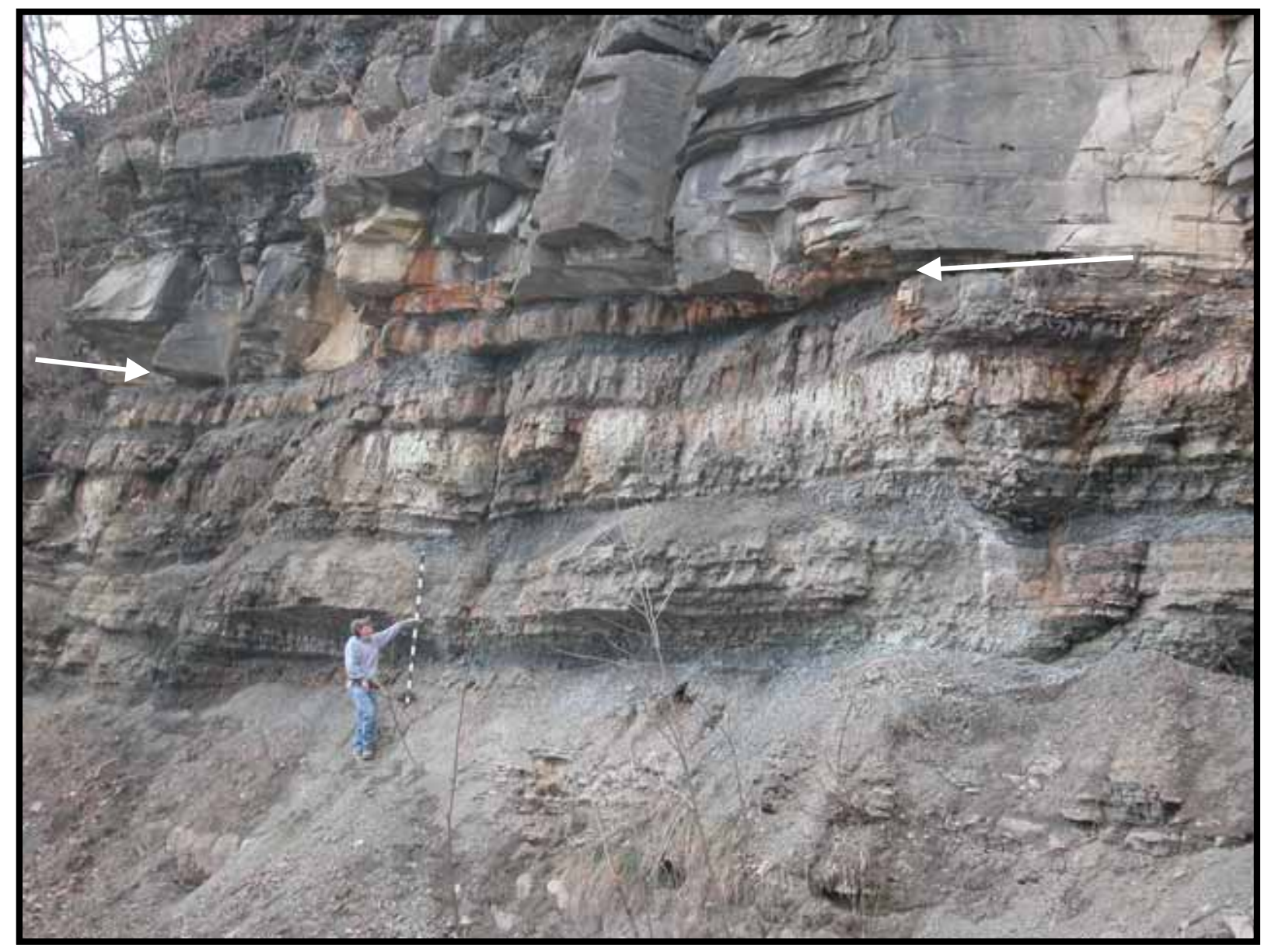

Figure 32. Photo ID \#0497: Photo shows scouring (indicated by arrows) of Unit 24 into lower units at Rowlesburg. 


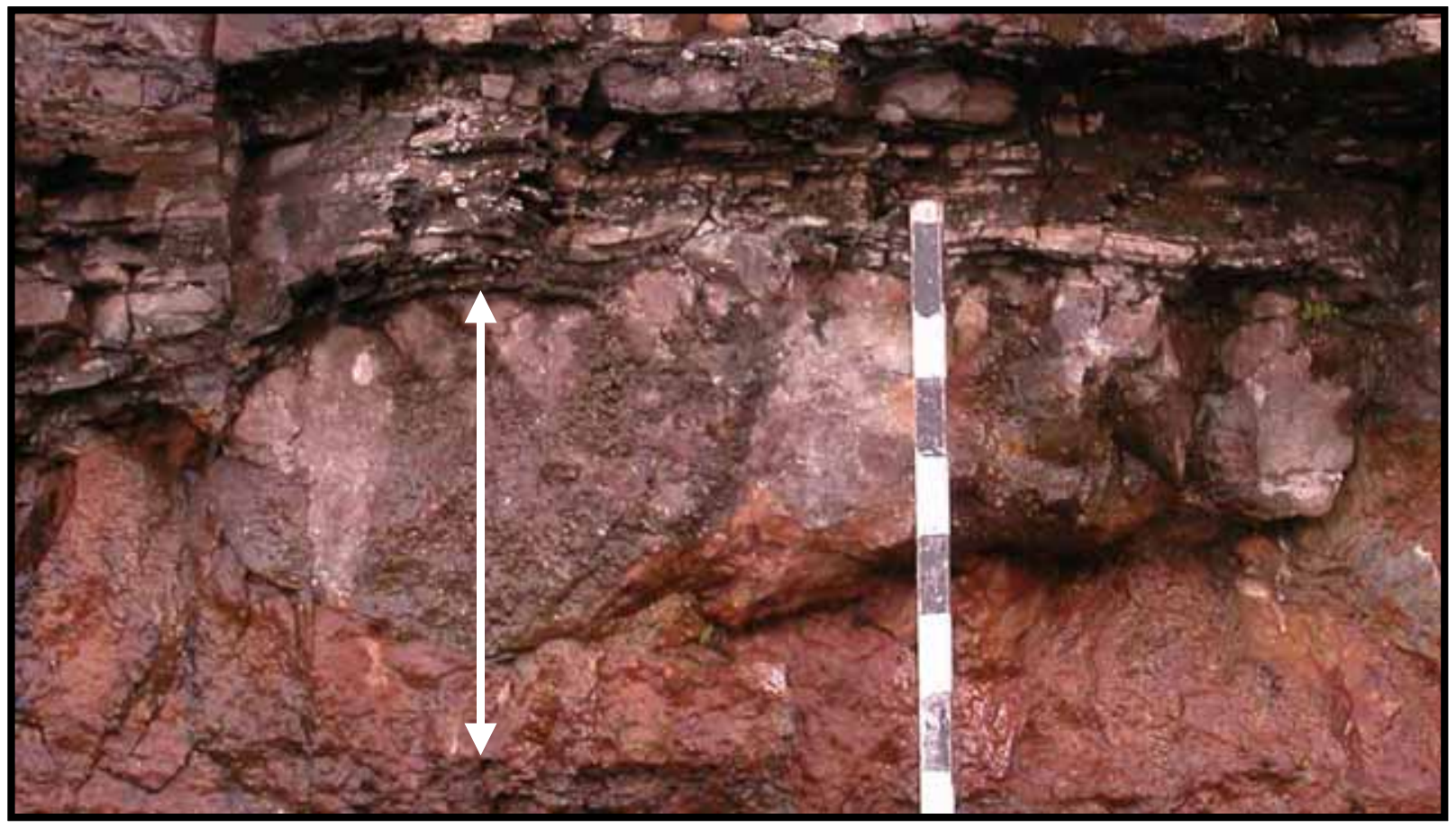

Figure 33. Photo ID \#0571: Photo shows close-up of quartz pebble conglomerate (shown by arrow) at base of Unit 34 at Rowlesburg noted in figure 30 . Scale in $10 \mathrm{~cm}$ increments. 


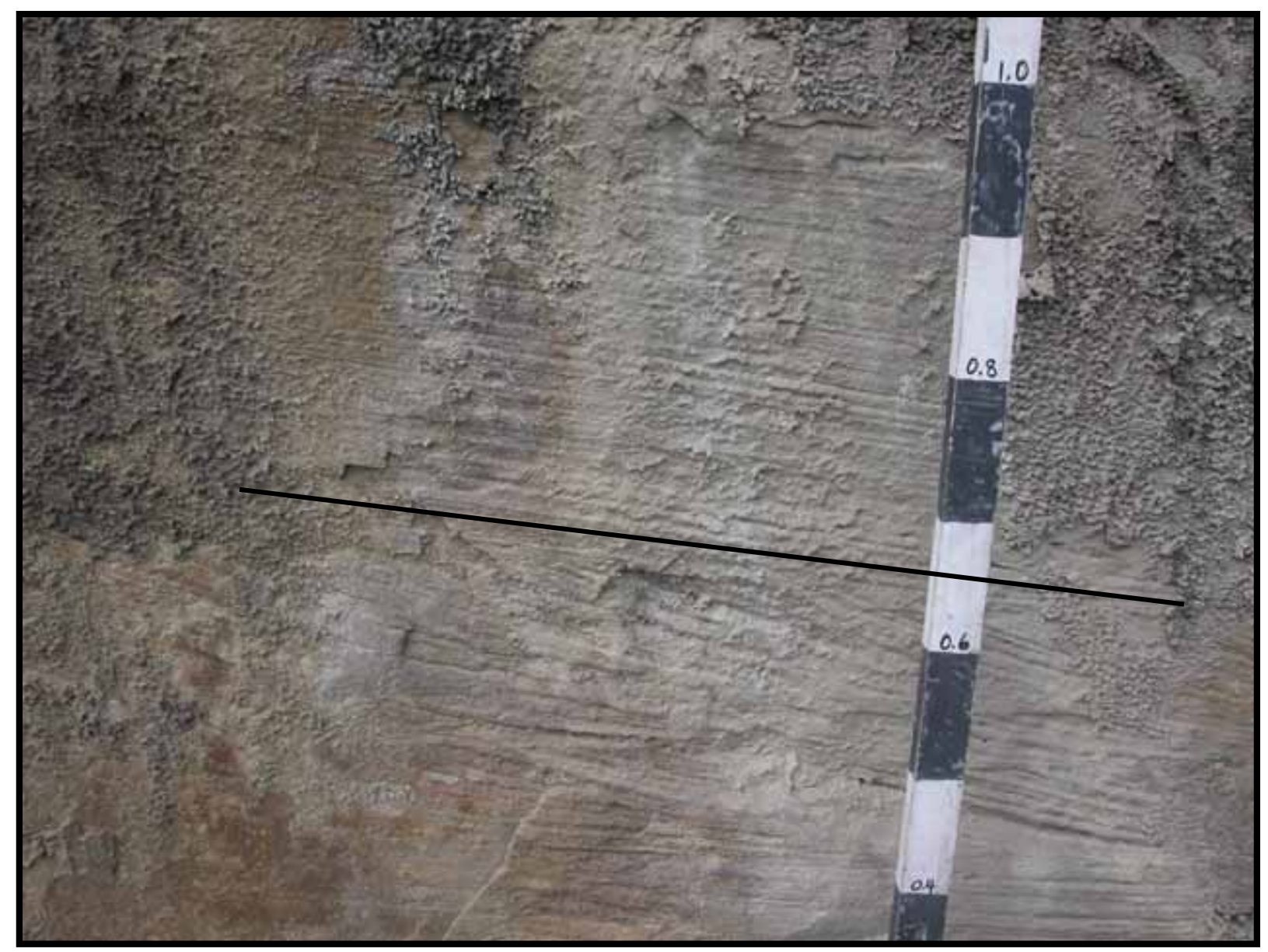

Figure 34. Photo ID \#0515: Photo shows low-angle inclined bedding above (indicated by line) and trough cross-bedding below in Unit 11 at Rowlesburg. 


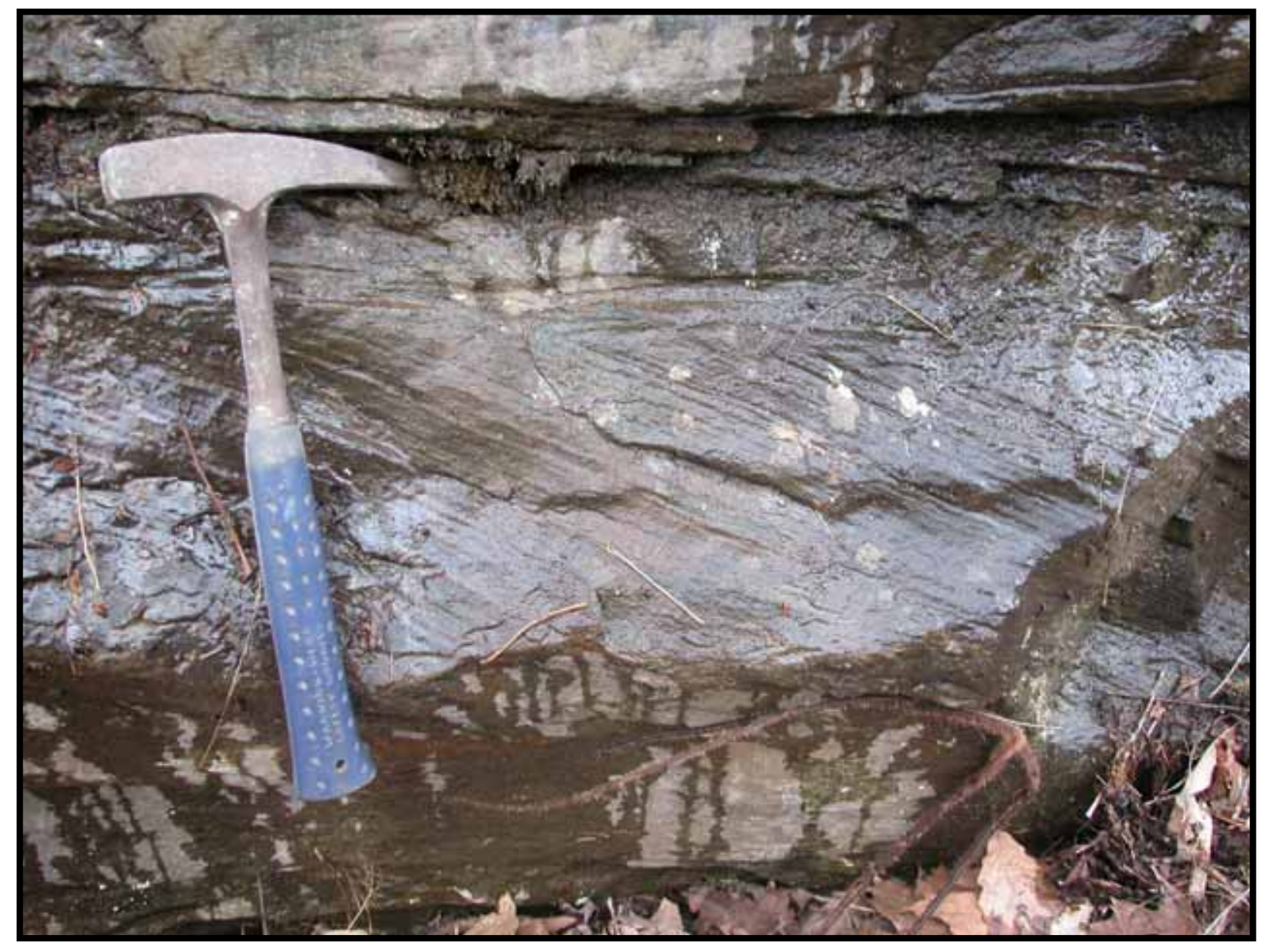

Figure 35. Photo ID \#0524: Photo shows large-scale planar cross-bedding in Unit 24 at Rowlesburg. 


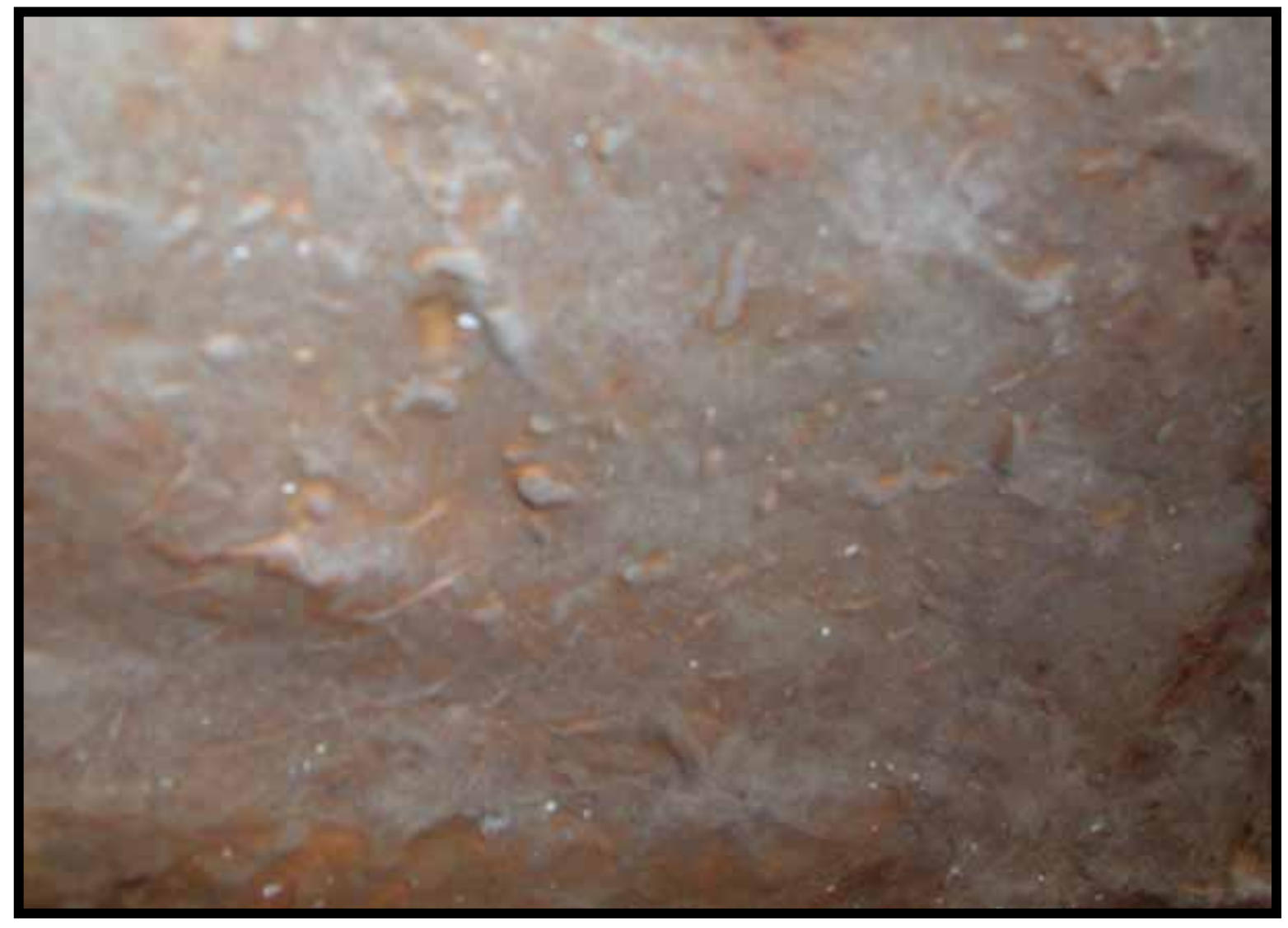

Figure 36. Photo ID \#0492: Photo shows trace fossils in the basal bedding plane of Unit 3 at Rowlesburg. 


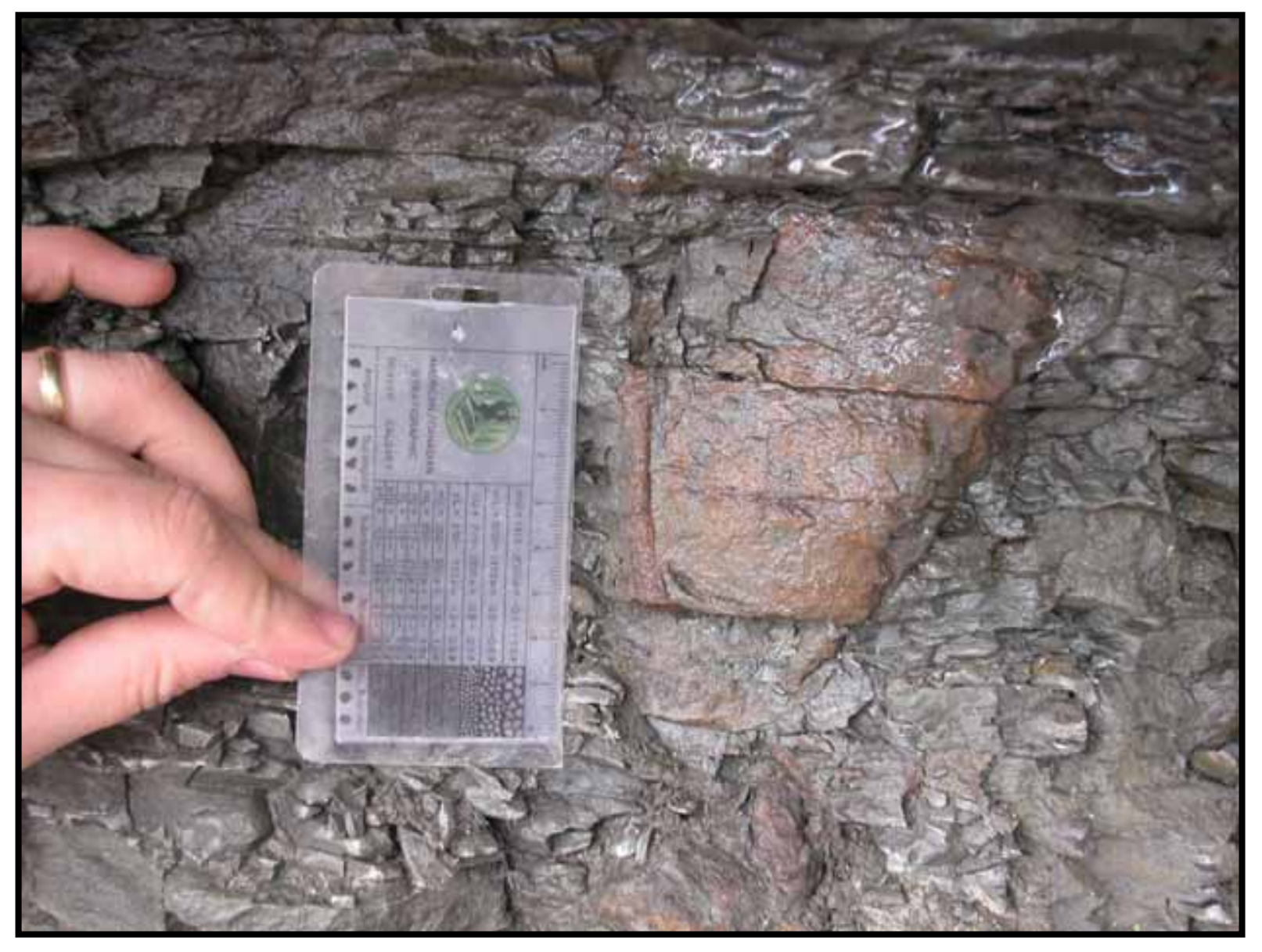

Figure 37. Photo ID \#0517: Photo shows large vertical burrow in Unit 11 at Rowlesburg. 


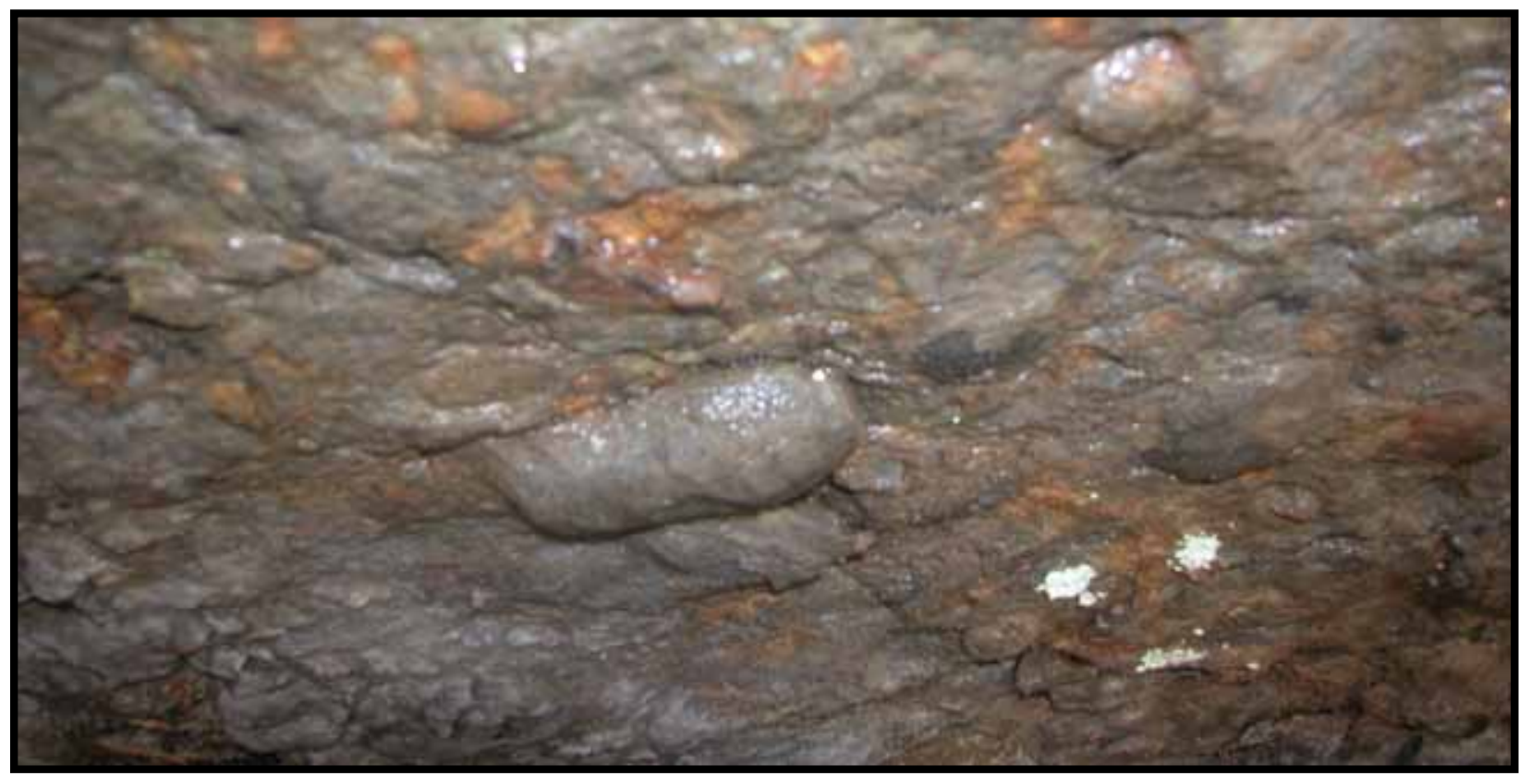

Figure 38. Photo ID \#0510: Photo shows burrows in the basal bedding plane of Unit 11 at Rowlesburg. 


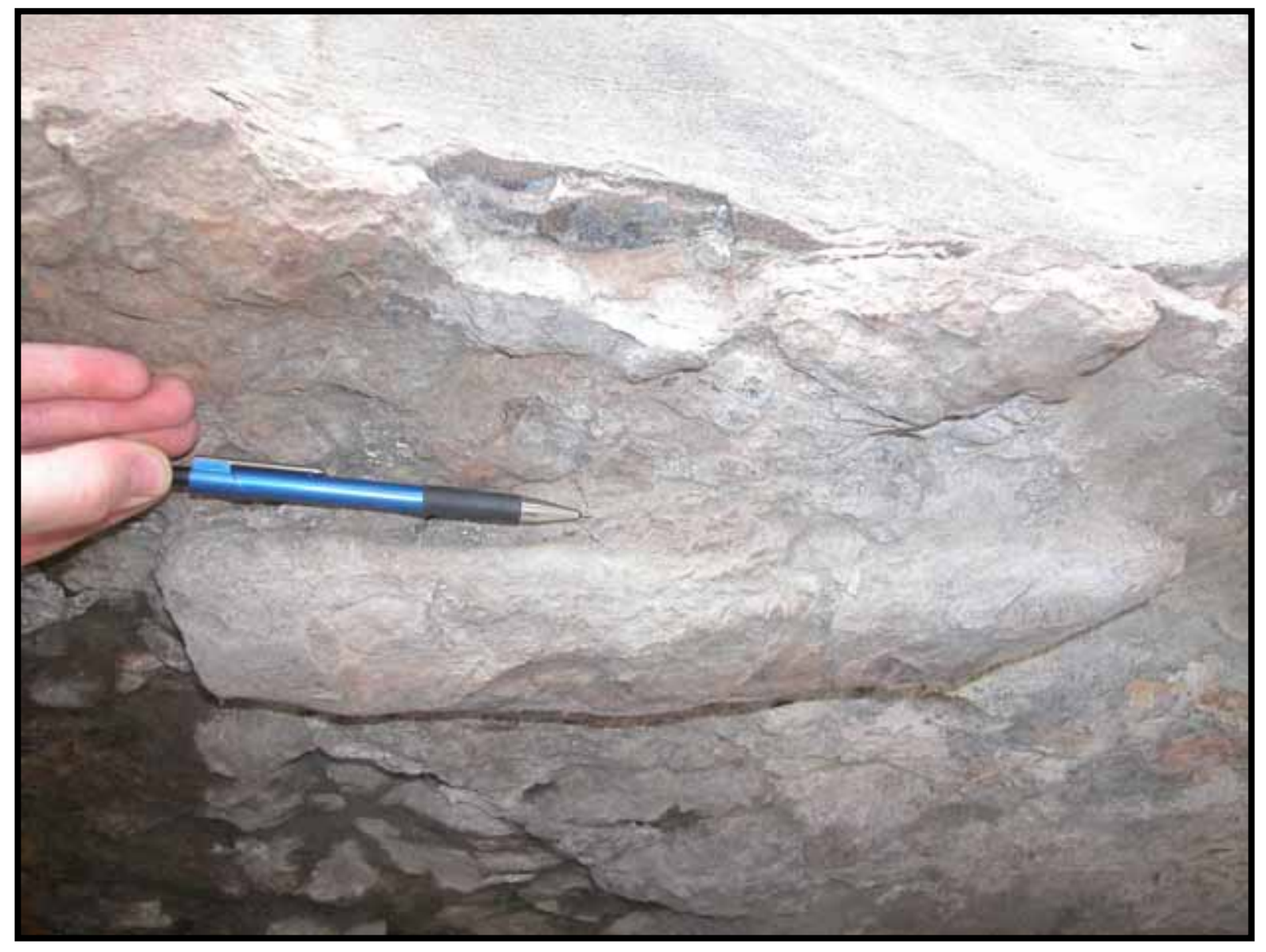

Figure 39. Photo ID \#0512: Photo shows large horizontal burrow in the basal bedding plane of Unit 11 at Rowlesburg. 


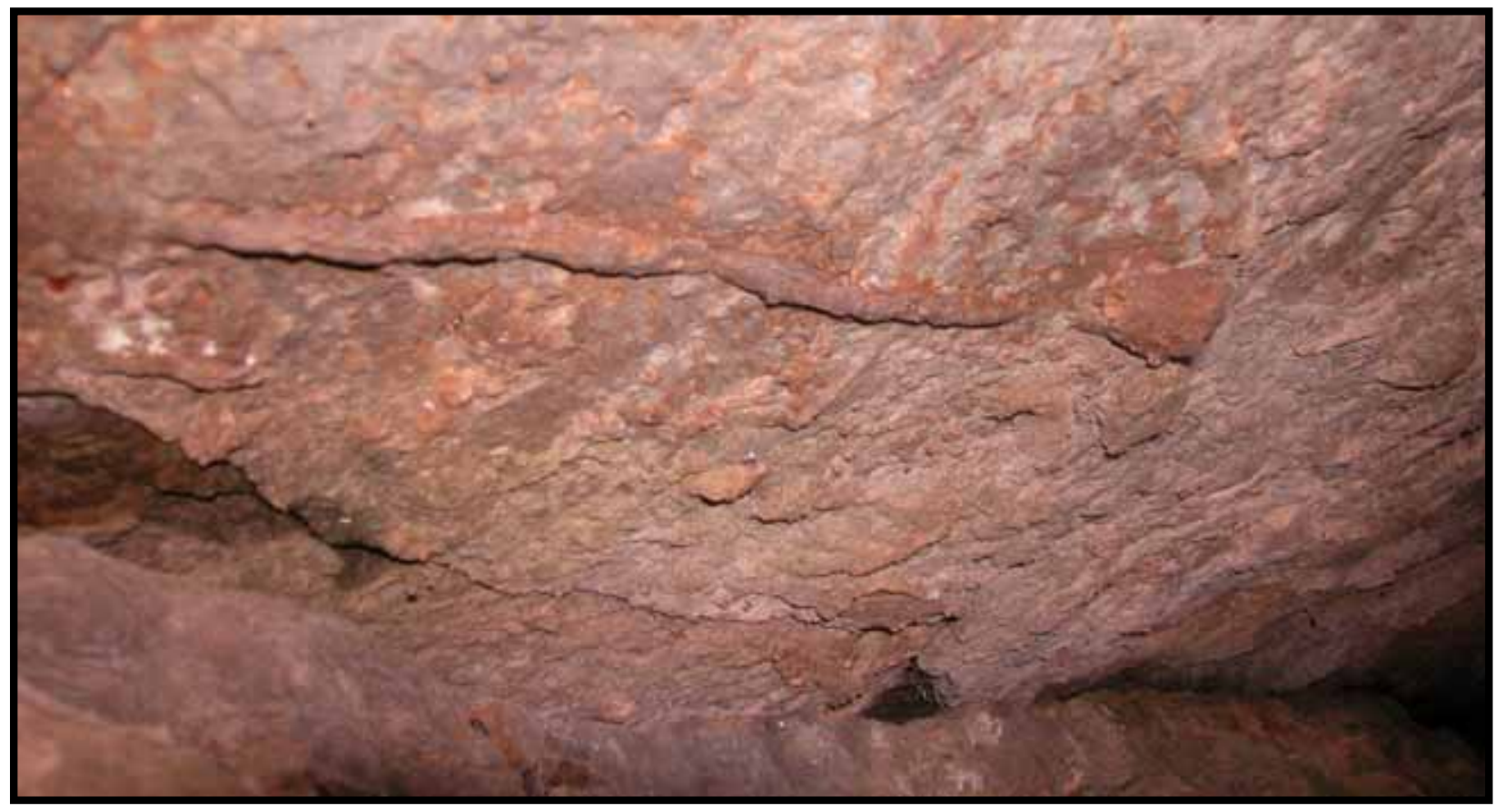

Figure 40. Photo ID \#0568: Photo shows horizontal burrow in the basal bedding plane of Unit 30 at Rowlesburg. 


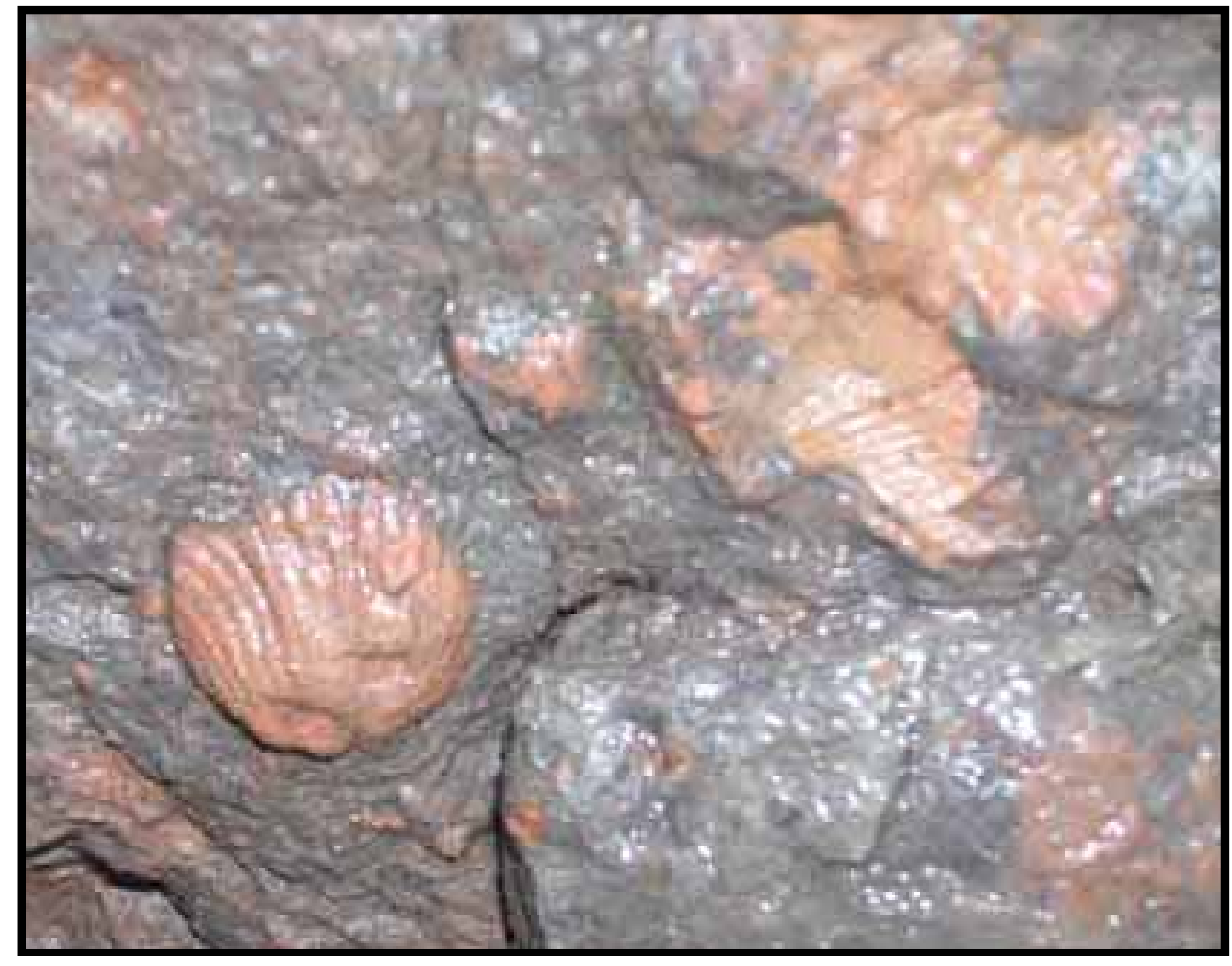

Figure 41. Photo ID \#0514: Photo shows brachiopods in the basal bedding plane of Unit 11 at Rowlesburg. 


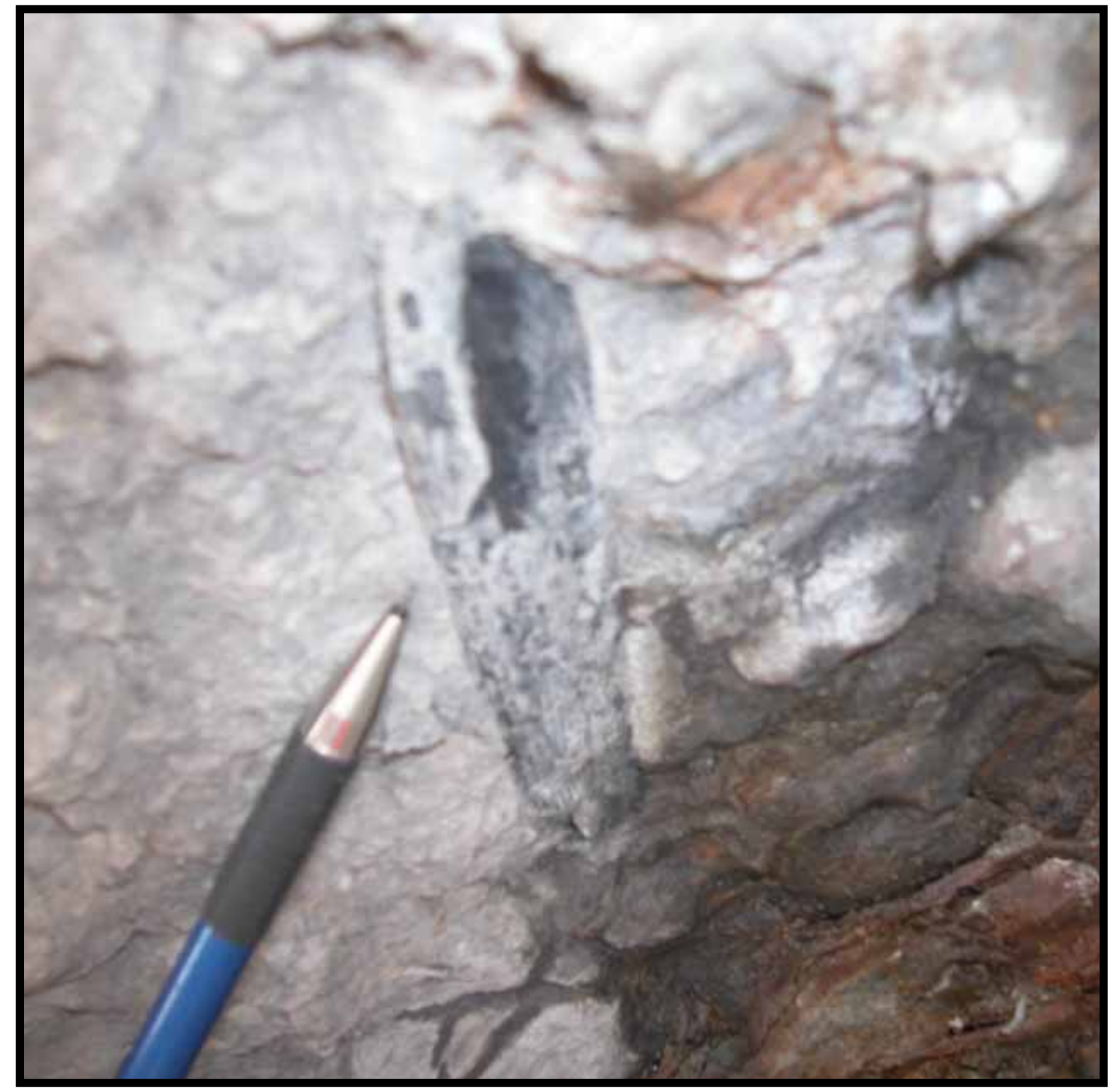

Figure 42. Photo ID \#0513: Photo shows coalified tree bark in the basal bedding plane of Unit 11 at Rowlesburg. 
Interpretation - Medium- to very fine-grained sandstones with scour base and overall finingupward sequence are interpreted as tidal channels. The dominant sedimentary structures in these tidal-channel sandstones at Rowlesburg include horizontal stratification, planar- and trough cross-bedding, reactivation surfaces, and ripples. Reactivation surfaces indicate a reversing of tidal currents. Clifton (1982) identified tidal-channel deposits with similar cross-bedding, reactivation surfaces, and ripple laminations. The idealized vertical sequence of a tidal-channel, as described by Clifton (1982), consists of a basal lag deposit overlain by cross-bedded or ripplebedded sandstone, structureless burrowed sandstone, and capped by shale. Shanmugam et.al. (2000) likewise interpreted sandstone with erosional base and lag, cross-beds, and a finingupward trend to be evidence of tidal-channel deposition. The erosional bases of Rockwell sandstones scour several meters into the underlying sediments, and shell material, quartz pebbles, and plant debris represent a lag deposit within the channel. The overall fining-upward trend of each sand body is indicative of tidal-channel infilling. The sandstone becomes progressively finer-grained up-section, and sedimentary structures become obscured by an increase in bioturbation and burrowing. The trace and body fossils reflect a high-diversity marine assemblage indicative of good circulation.

Thin beds and lenses of siltstone and sandstone are interpreted as washover deposits within the dominantly shale units of the outer-lagoon facies. Basal contacts are sharp with no significant scour. Some units contain plant debris, and bioturbation is common. The alternation of siltstone, sandstone, and shale may show a cyclicity of wave action in the outer lagoon behind the barrier island. The coarser-grained layers represent deposition from storm washovers, whereas the shale represents deposition from suspension during quiet times in the lagoon (Shanmugam et al., 2000). Horizontal stratification is most common where washover deposition 
was by shallow flow above normal high tide, and medium-scale foreset stratification where washover sands built into a shallow standing body of water (McCubbin, 1981). Other characteristics of washover deposits include the presence of shell debris from the open ocean and burrows (McCubbin, 1981).

\section{River-Influenced Inner Lagoon}

\section{Restricted Subtidal}

Description - The inner-lagoon facies is characterized by interbedded sandstone, siltstone, shale, and mudstone in a generally coarsening-upward sequence.

Grain size of the sandstone ranges from very-fine- to fine-grained. The sandstone has a reddish color and occurs in units from $10 \mathrm{~cm}$ to $3 \mathrm{~m}$ thick. Bedding is very thin to very thick, grading laterally into siltstone (Fig 3). Typically units of this facies have a sharp basal contact (Fig. 43; locally erosional), and the rocks coarsen and/or thicken upward (Fig. 44) from thinly interbedded siltstone and shale to medium-bedded sandstone. Several sandstone units exhibit a channel form. Common sedimentary structures include ripple bedding, horizontal stratification, and cross-bedding. Mud blocks (meter size) encased in sandstone were identified in a bed at LaVale (Fig. 45). Plant debris, bioturbation, and burrows (Fig. 46 \& 47; Skolithos and Cruziana) are present in this facies. In addition, Bjerstedt (1987) identified Isopodichnus, Rusophycus, Planolites ichnogenera. No body fossils were observed in this study, but Bjerstedt (1987) identified linguloid and rhynchonellid brachiopods and Beuthin (1986) reported bivalves.

The siltstone contains ripple bedding, flaser and wavy bedding, cross-bedding, and horizontal stratification. Bed thickness varies laterally. Siltstones show bioturbation and burrows on bedding surfaces, and some contain poorly developed root traces. 


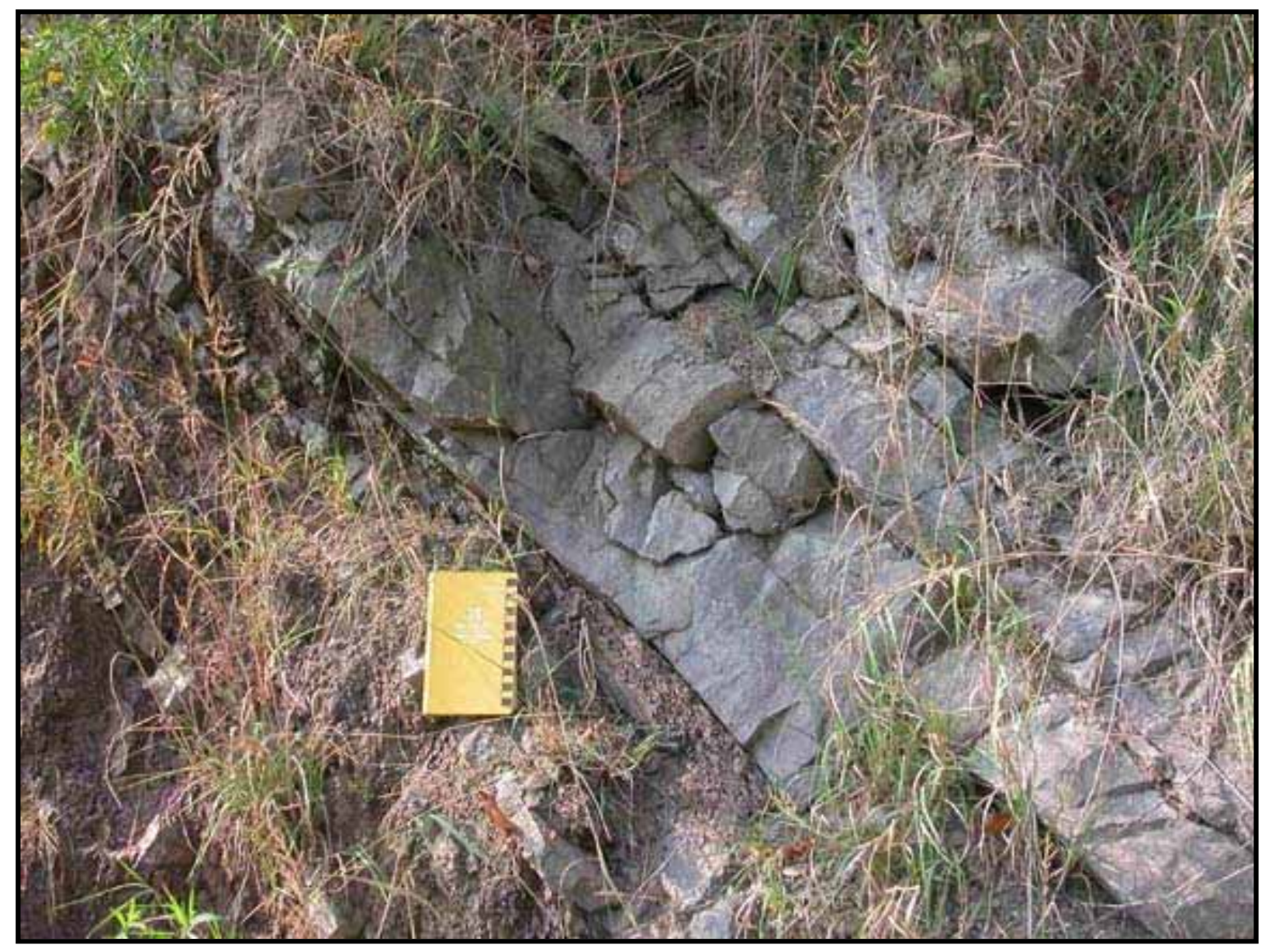

Figure 43. Photo ID \#1087: Photo shows sharp basal contact of Unit 1 with the underlying Hampshire red beds at LaVale. 


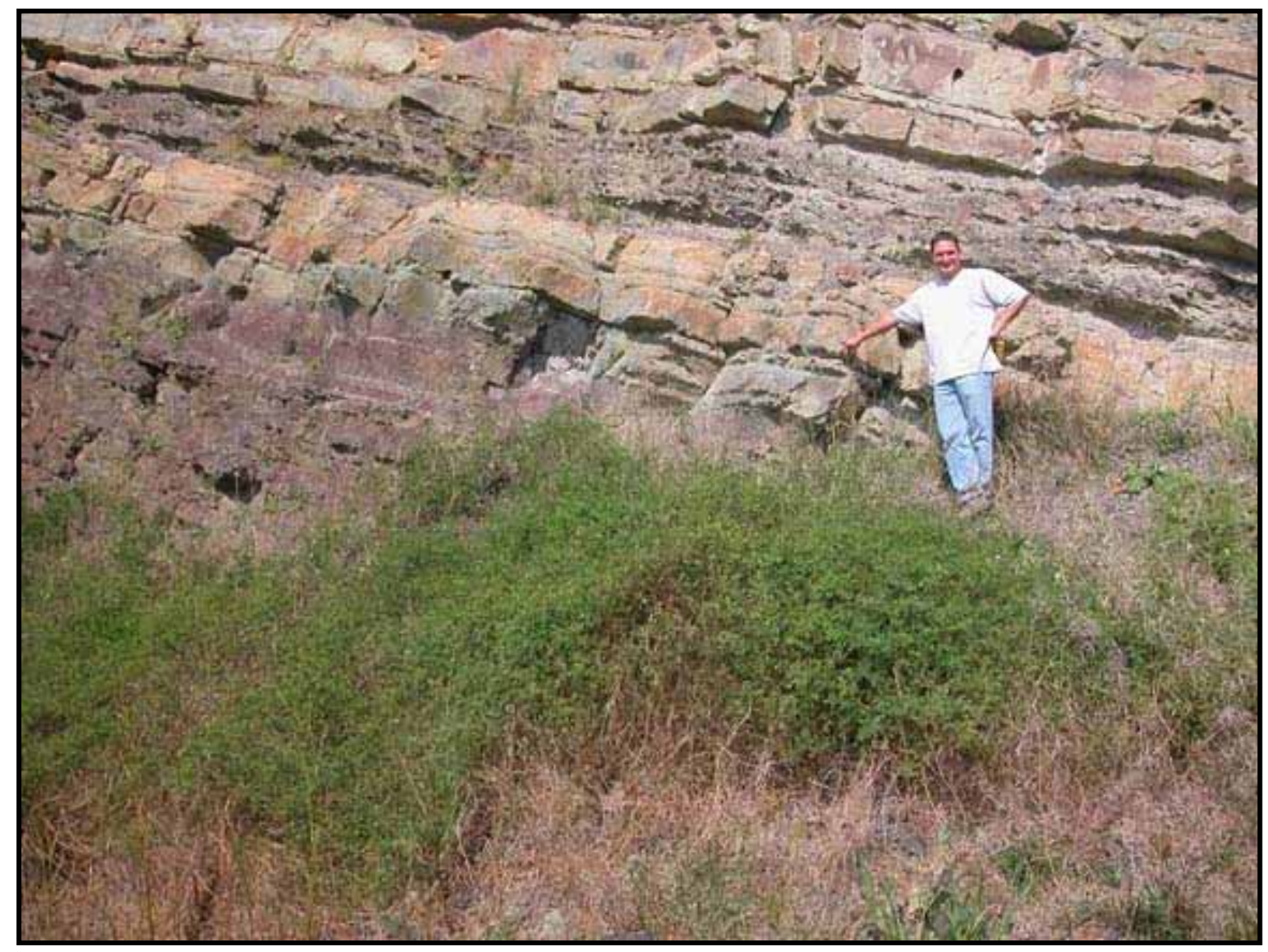

Figure 44. Photo ID \#1150: Photo shows coarsening and thickening upward beds at Finzel. Note the sharp basal contact with the Hampshire red beds 


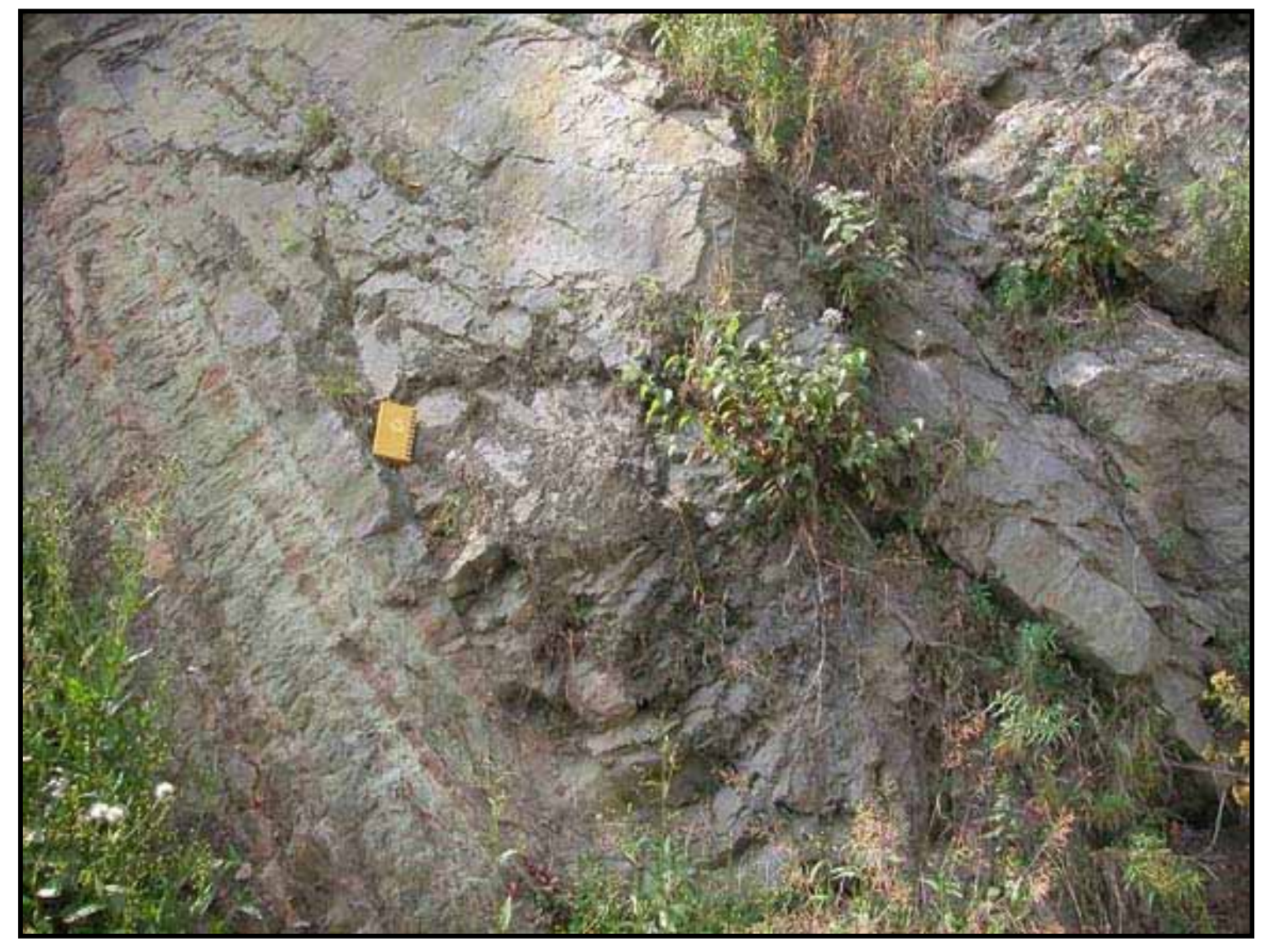

Figure 45. Photo ID \#1093: Photo shows meter scale mud blocks encased in sandstone in Unit 4 at LaVale. 


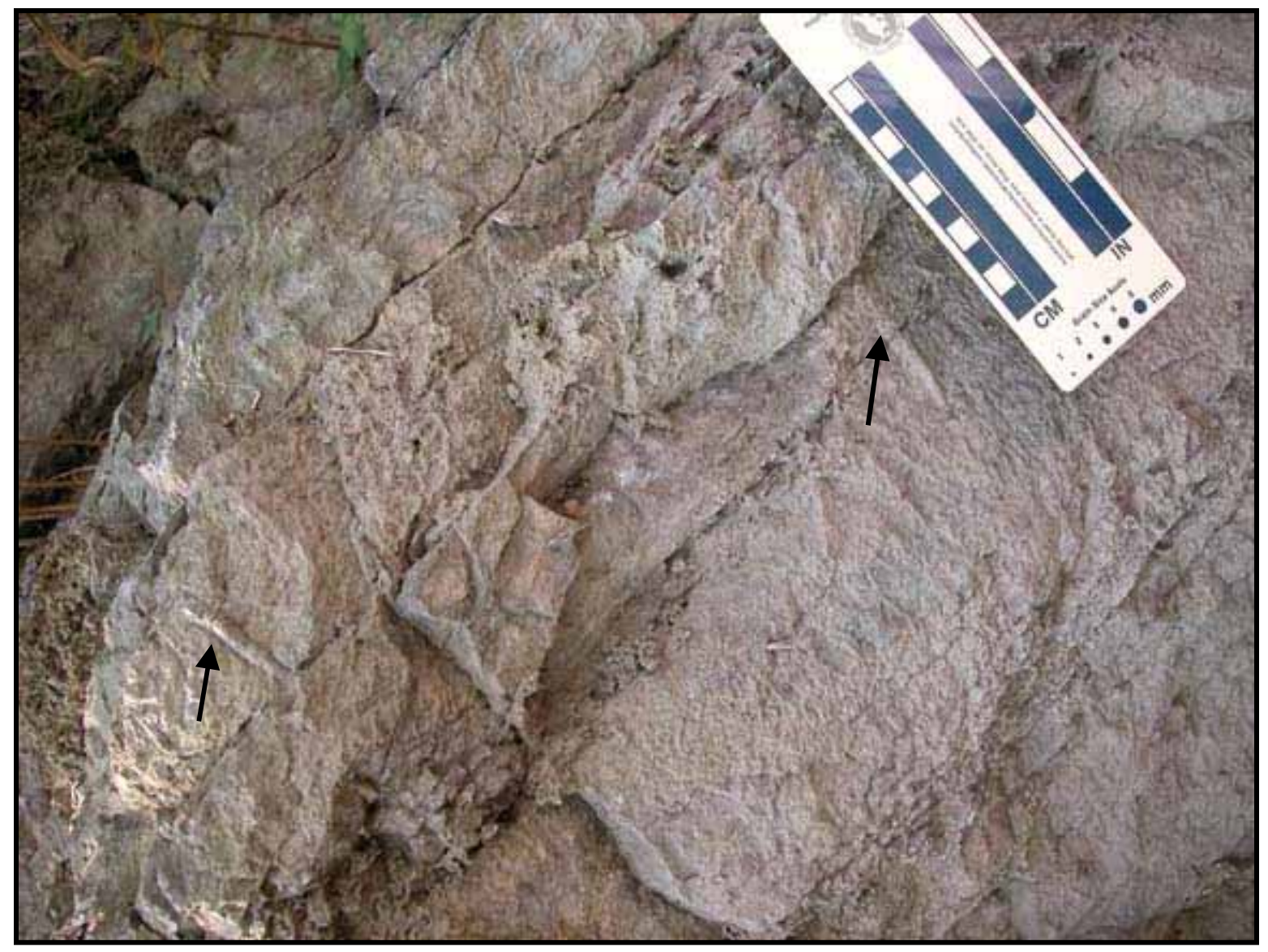

Figure 46. Photo ID \#1091: Photo shows two prominent vertical burrows (indicated by arrows) in Unit 4 at LaVale. Stratigraphic-up is to upper left. 


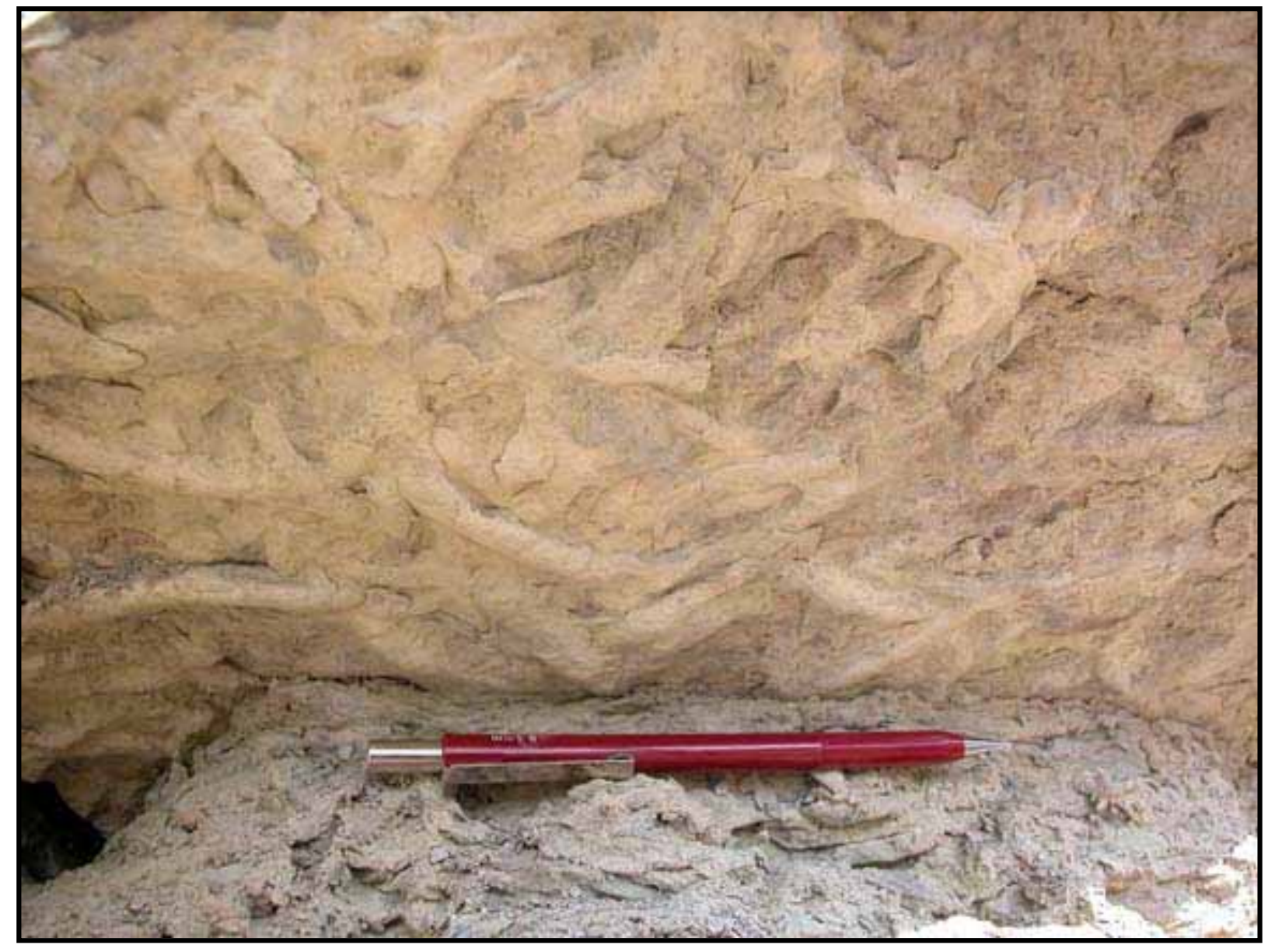

Figure 47. Photo ID \#1152: Photo shows horizontal burrows in the basal bedding plane of Unit 4 at Finzel, pencil for scale. 
The shale is generally fissile, weathers crumbly to platy, and grades into siltstone, locally with lenticular bedding (Fig. 48). Silty-shale beds contain root traces or faint burrows. Mudstone units typically grade into shale and have a red mottled appearance. Unidentifiable shell fragments are present and weakly developed paleosols (Fig. 49) were observed. Siderite nodules and some scattered coalified plant debris also occur.

Interpretation - The lower $20 \mathrm{~m}$ at the LaVale and Finzel outcrops represent the restricted-subtidal facies of an inner lagoon. This section is dominated by alternating sandstone, siltstone, and shale layers, interpreted as episodic tidal and/or fluvial influence into a lagoon (Nichol et al, 1997). Wavy, flaser, and lenticular bedding may indicate tidal influence on the fine-grained sediment. The dominance of fine-grained sediments indicates a low-energy environment. Furthermore, the reduced diversity of marine burrows and body fossils and a dominance by linguloid brachiopods reflect brackish salinity and possibly restricted circulation. Many recent lingulids are euryhaline, indicated by their presence in nearshore and brackish water environments (Craig, 1952 in Cherns, 1979). Basal contacts of the sandstone are sharp but locally erosional, and some sandstones exhibit a channel form. Mud blocks encased in sandstone represent slumps of the tidal-channel bank during floods and/or meandering. Root traces and paleosols signify temporary periods of subaerial exposure of these lagoonal sediments.

Typically, units of this facies exhibit an overall coarsening-upward trend from shale to fine-grained sandstone. This trend resulted from increasing sediment influx from adjacent fluvial channels. Stratigraphically above lies a bayhead delta, and episodic sedimentation in the restricted lagoon is a direct result of deltaic progradation. With the initiation of subaqueous delta growth, the bay became shallower and accumulated progressively coarser-grained sediment, similar to the Atchafalaya delta, Louisiana as described by Van Heerden \& Roberts (1988). 


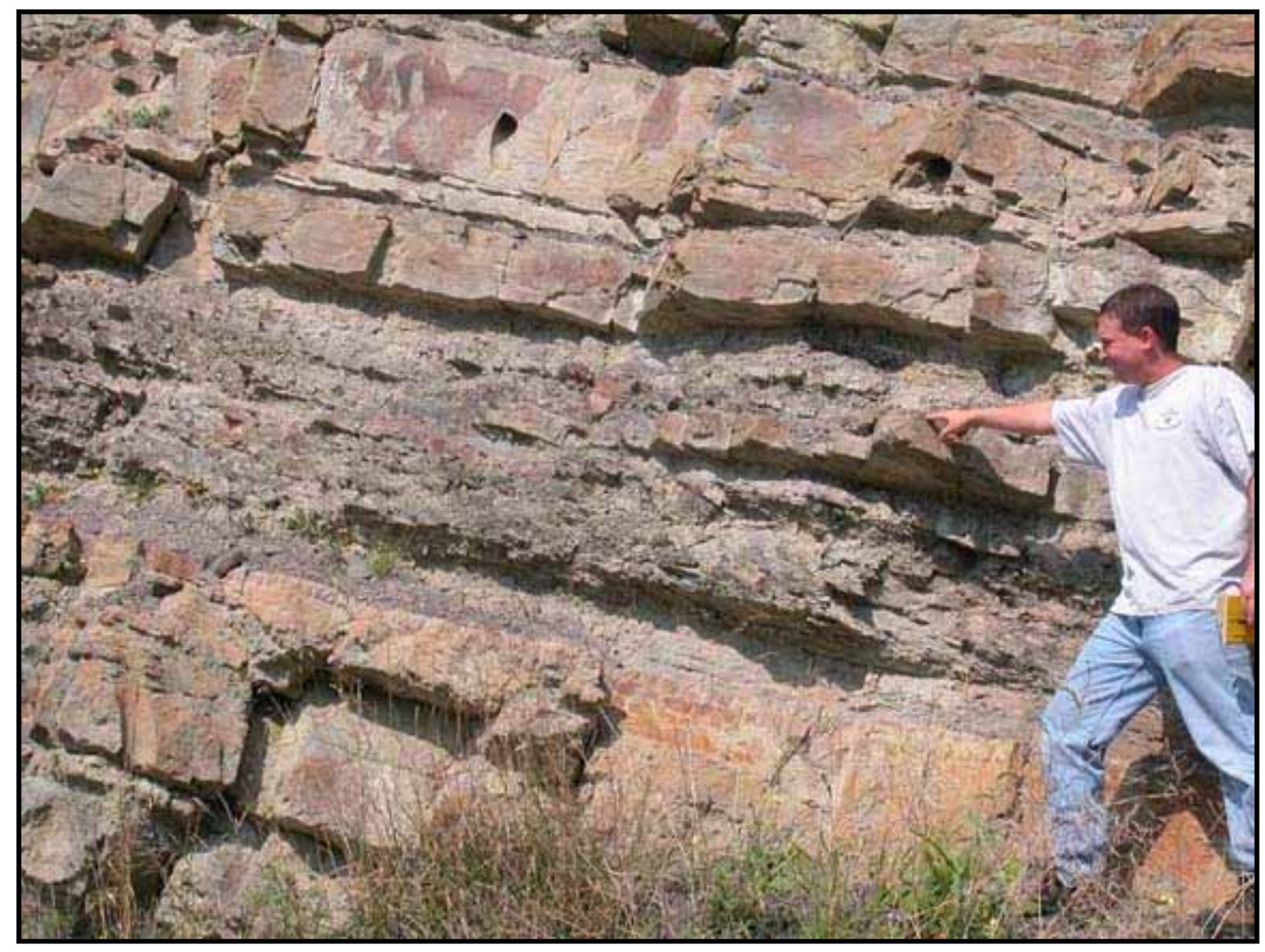

Figure 48. Photo ID \#1151: Photo shows lenticular bedding in Unit 4 at Finzel. 


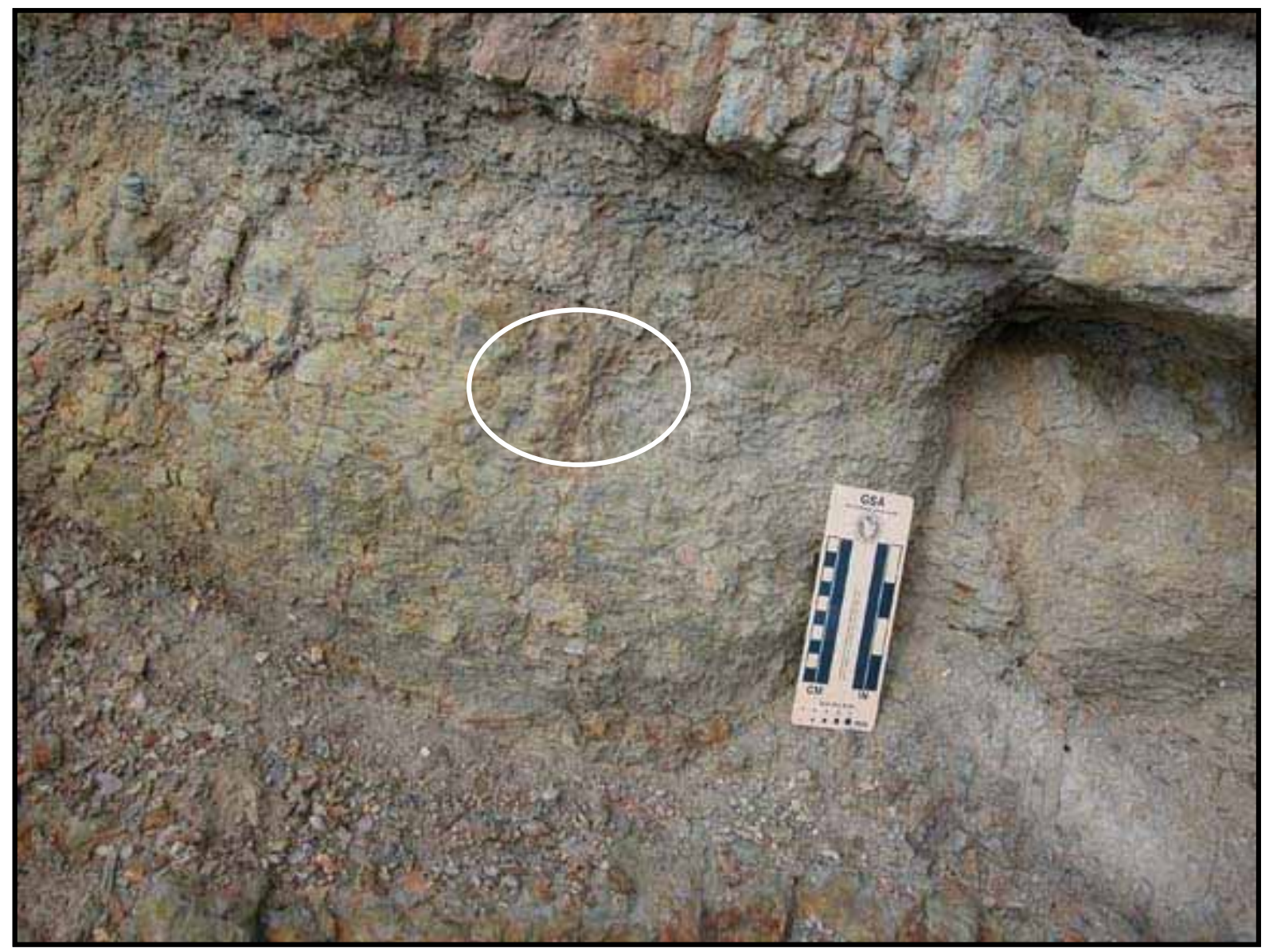

Figure 49. Photo ID \#1162: Photo shows a possible paleosol in Unit 8 at Finzel. Rust colored areas (for example, inside circle) appeared to be mottled root traces on outcrop. 


\section{Bayhead Delta}

Description - The bayhead delta facies contains two different types of sandstone bodies. Type 1, primarily at Finzel, fines upward and contains thin shale breaks. Type 2, only at LaVale, thickens and/or coarsens upward. The Finzel outcrop may expose the very base of the barrier island sandstone in the upper $6 \mathrm{~m}$ of section. Marine mollusks occur in the uppermost sandstone here.

The type 1 sandstone is very fine- to medium-grained, and fines upward in the section (Fig. 50). Minor shale breaks occur throughout. The color is generally light gray and weathers to a rusty brown. Sandstone units range from 2 to $15 \mathrm{~m}$ in thickness. Bedding is typically medium to thick, but overall bedding thins upward (Fig. 50). Bedding contacts range from sharp and undulatory to erosional (Fig. 51). The basal sandstone has a thin lag of mud clasts. Sedimentary structures include small-scale, low-angle, planar cross-bedding, trough crossstratification, and horizontal stratification. Small-scale ripple bedding and flaser bedding (Fig. 52) are present near the top of the thickest sandstone. Internal channelized bedforms (Fig. 53), some containing coal seams, were also observed. Soft-sediment deformation structures such as slump blocks are present. Plant debris and root traces are common as well. Some upper bedding surfaces contain extensive bioturbation, and one vertical burrow (5 cm long and $5 \mathrm{~mm}$ wide) was recorded.

The type 2 sandstone is very- fine- to fine-grained, and some units exhibit a coarseningupward trend (Fig. 54). The sandstone is red to green-gray; shale breaks are red-brown with a hackly to blocky texture and minor mottling. Sandstone units range from a few centimeters to 3 meters thick. Bedding varies from thin to thick (Fig. 55), and sandstone beds generally thicken upward as shale breaks (up to $30 \mathrm{~cm}$ ) thin. Basal contacts are typically sharp but rarely erosional 


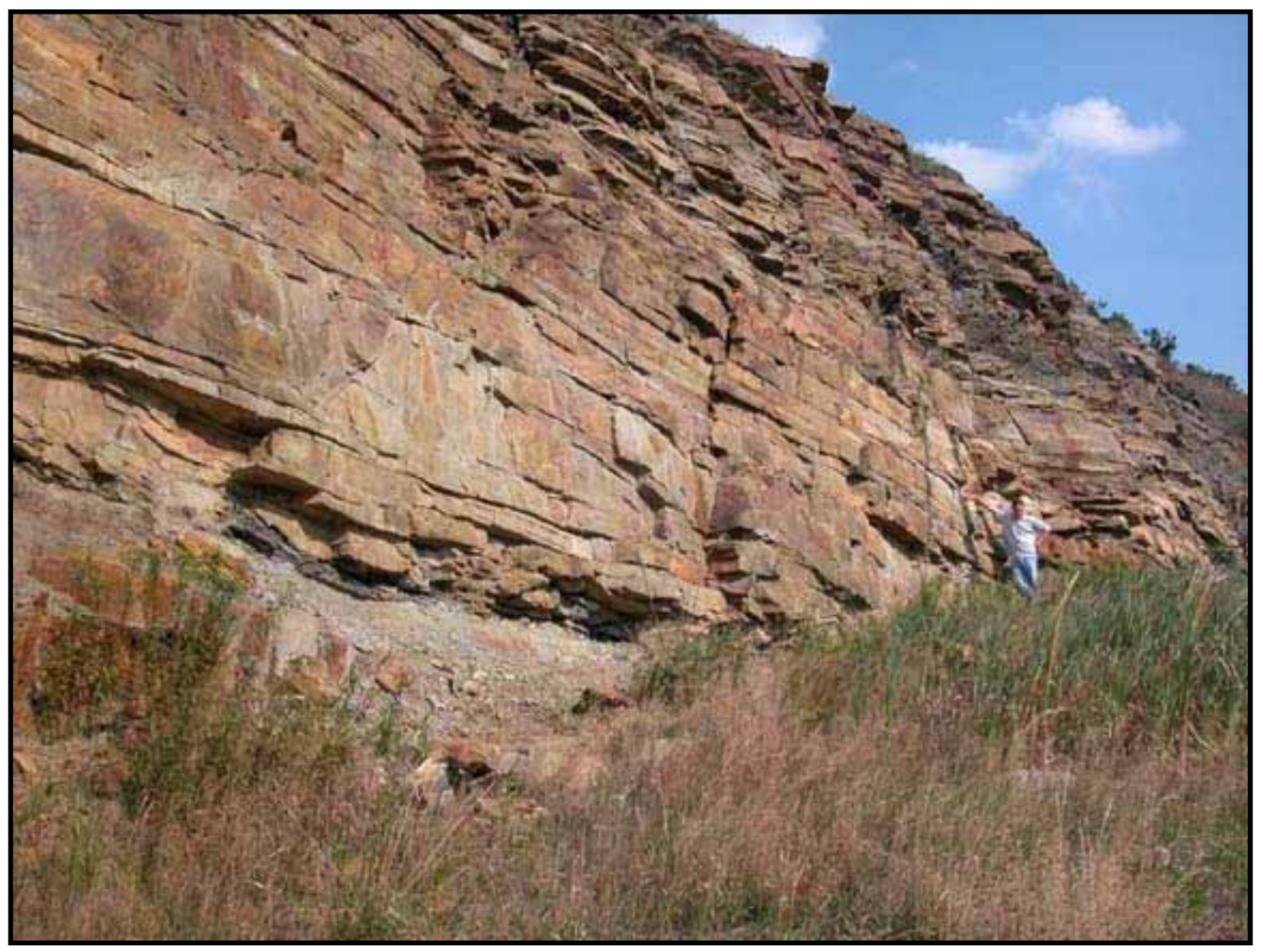

Figure 50. Photo ID \#1156: Photo shows a fining-upward sequence of distributary channels with intermediate shale breaks in Unit 13 at Finzel. 


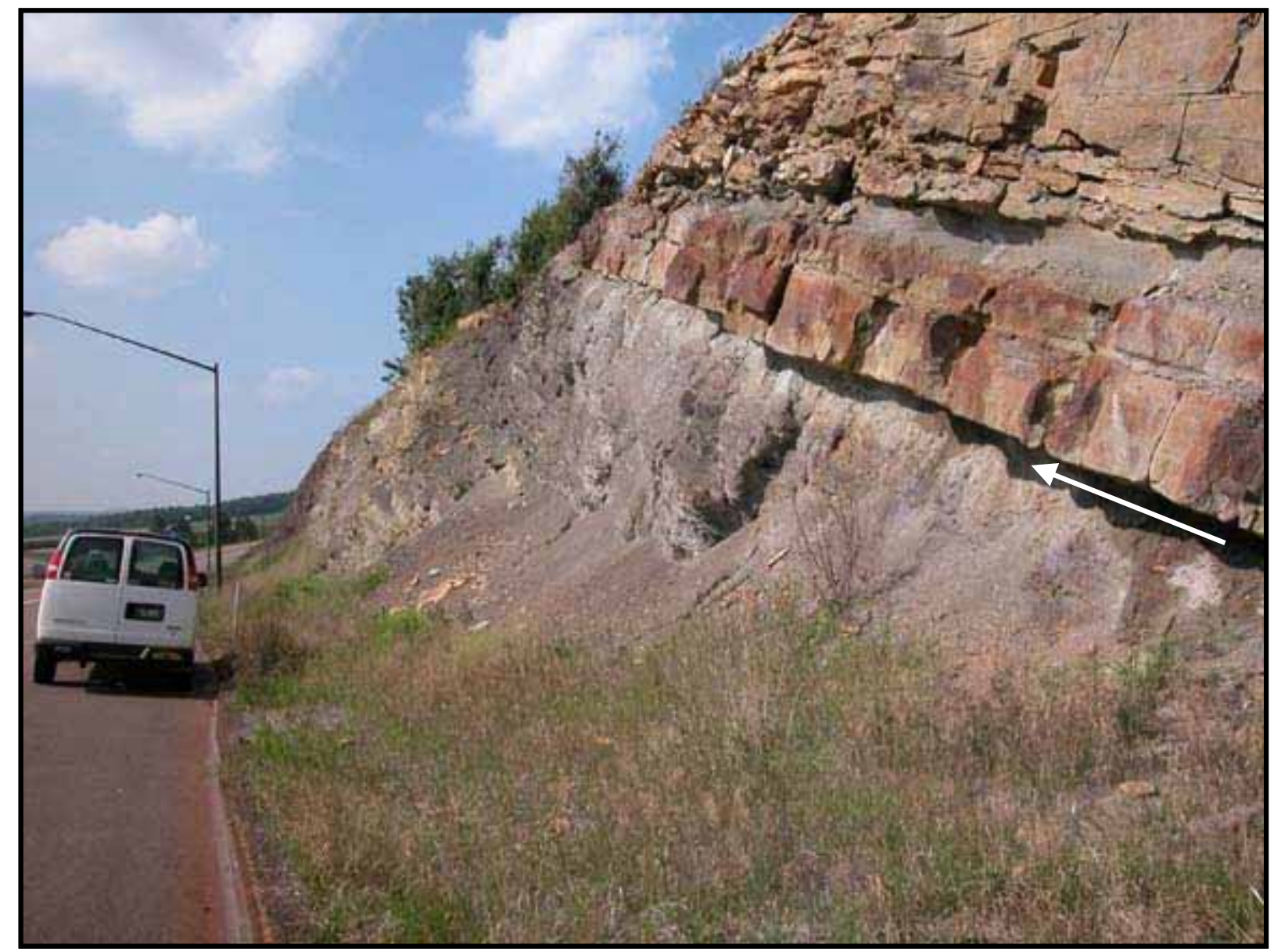

Figure 51. Photo ID \#1157: Photo shows erosional scour base (indicated by arrow) of the distributary channel sandstone in Unit 11 at Finzel. 


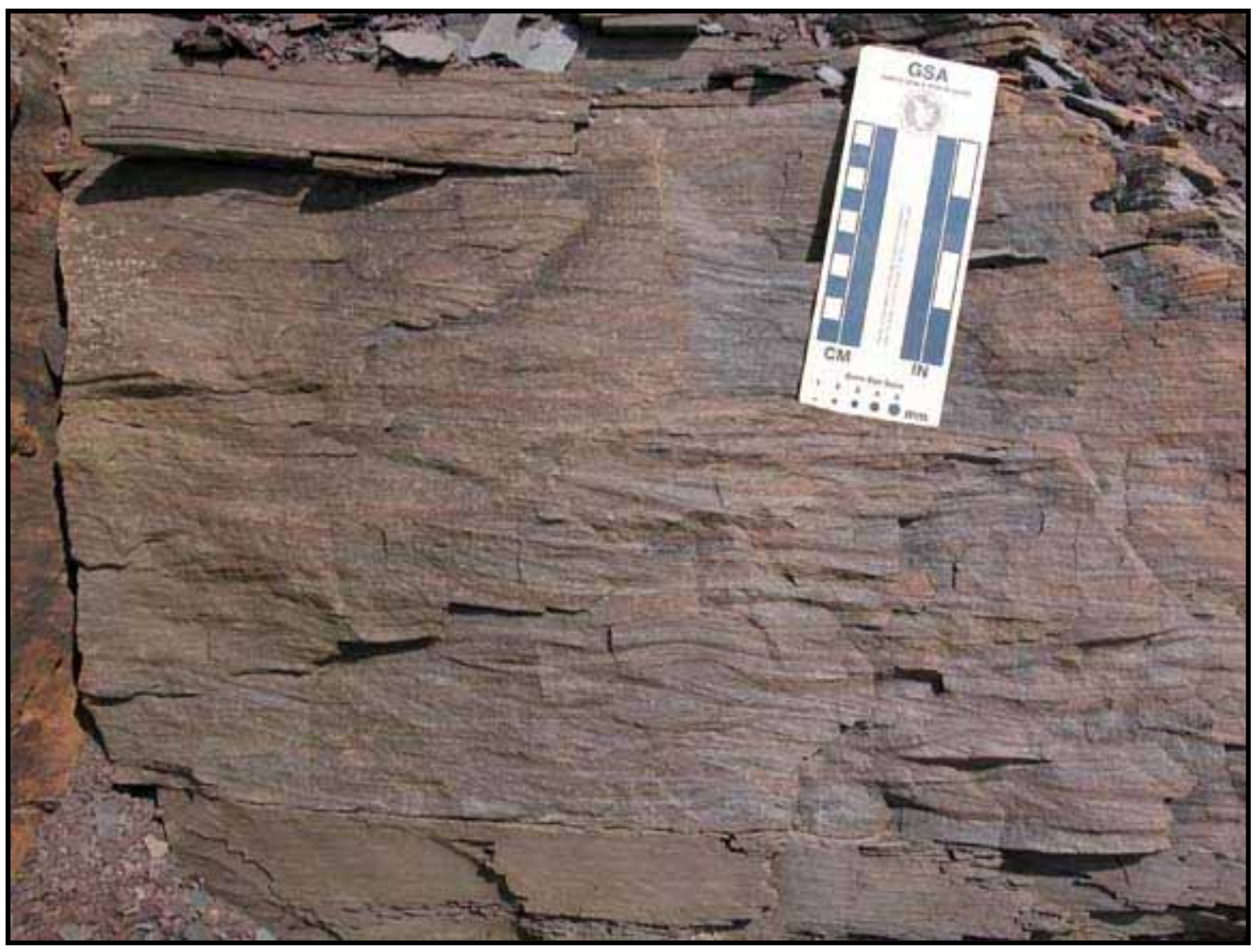

Figure 52. Photo ID \#1160: Photo shows flaser bedding in Unit 13b at Finzel. 


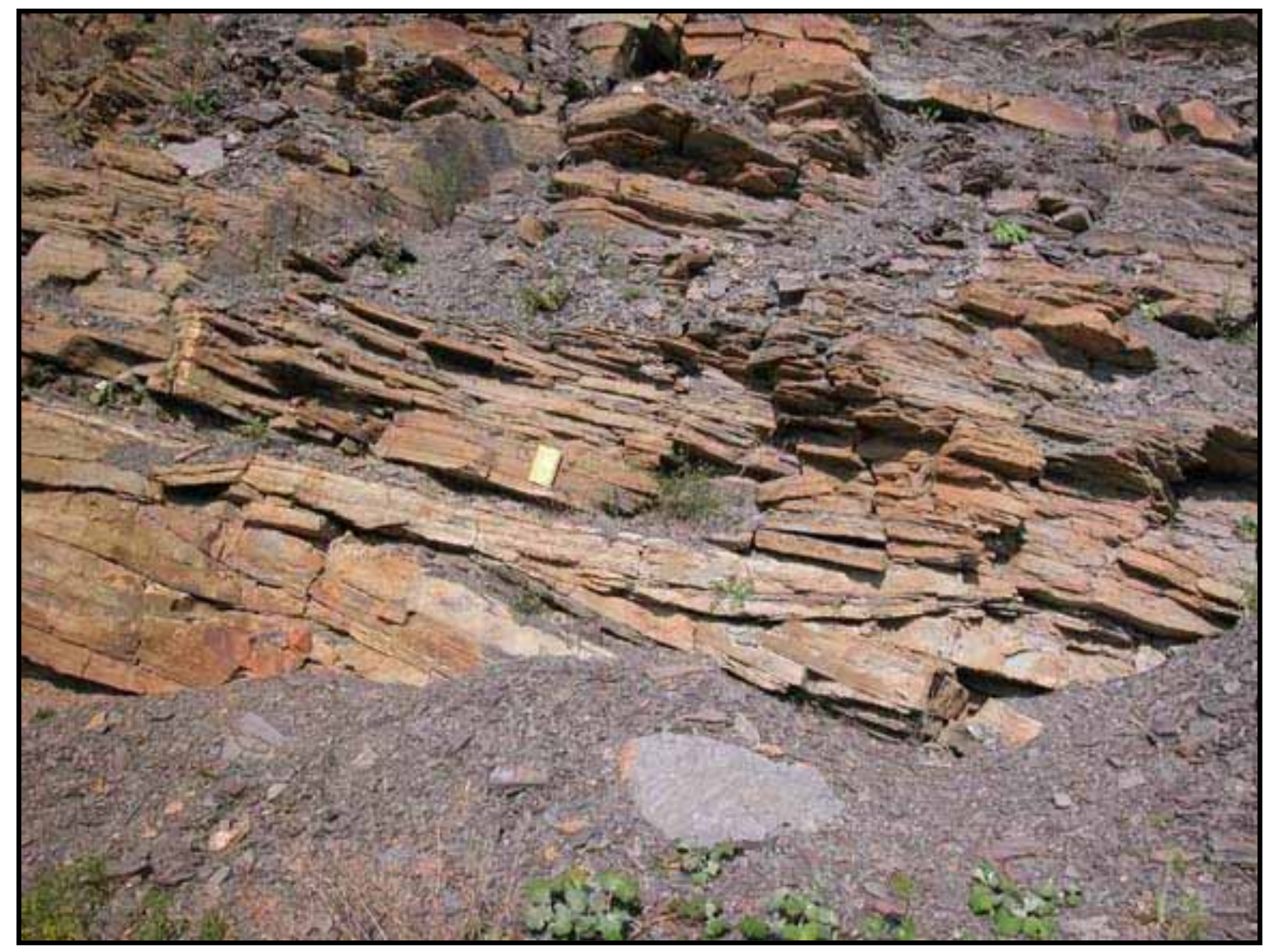

Figure 53. Photo ID \#1158: Photo shows internal channelized bed forms within Unit $13 b$ at Finzel. 


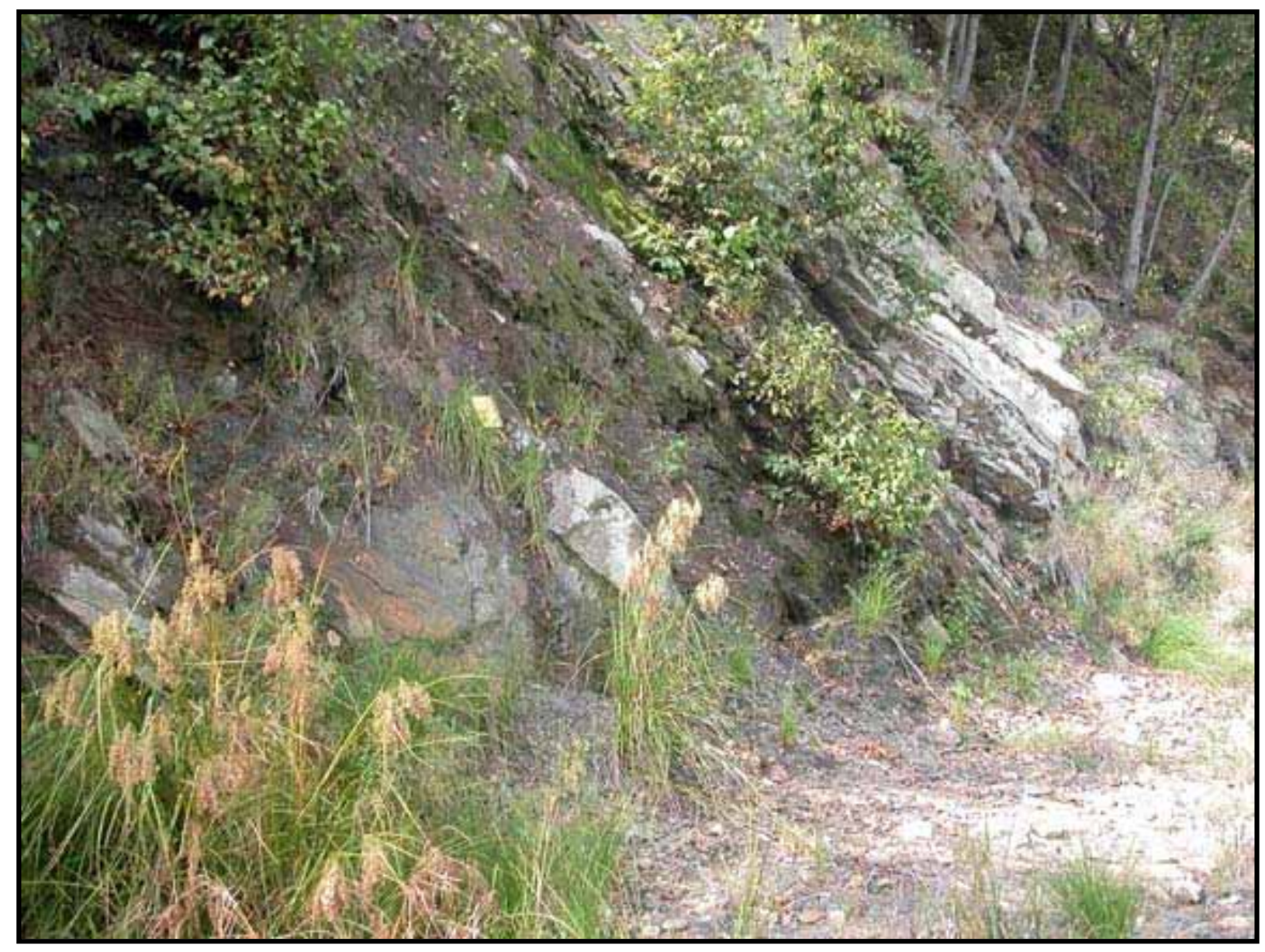

Figure 54. Photo ID \#1094: Photo shows a coarsening-upward trend in Unit 17 at LaVale, notebook for scale. 


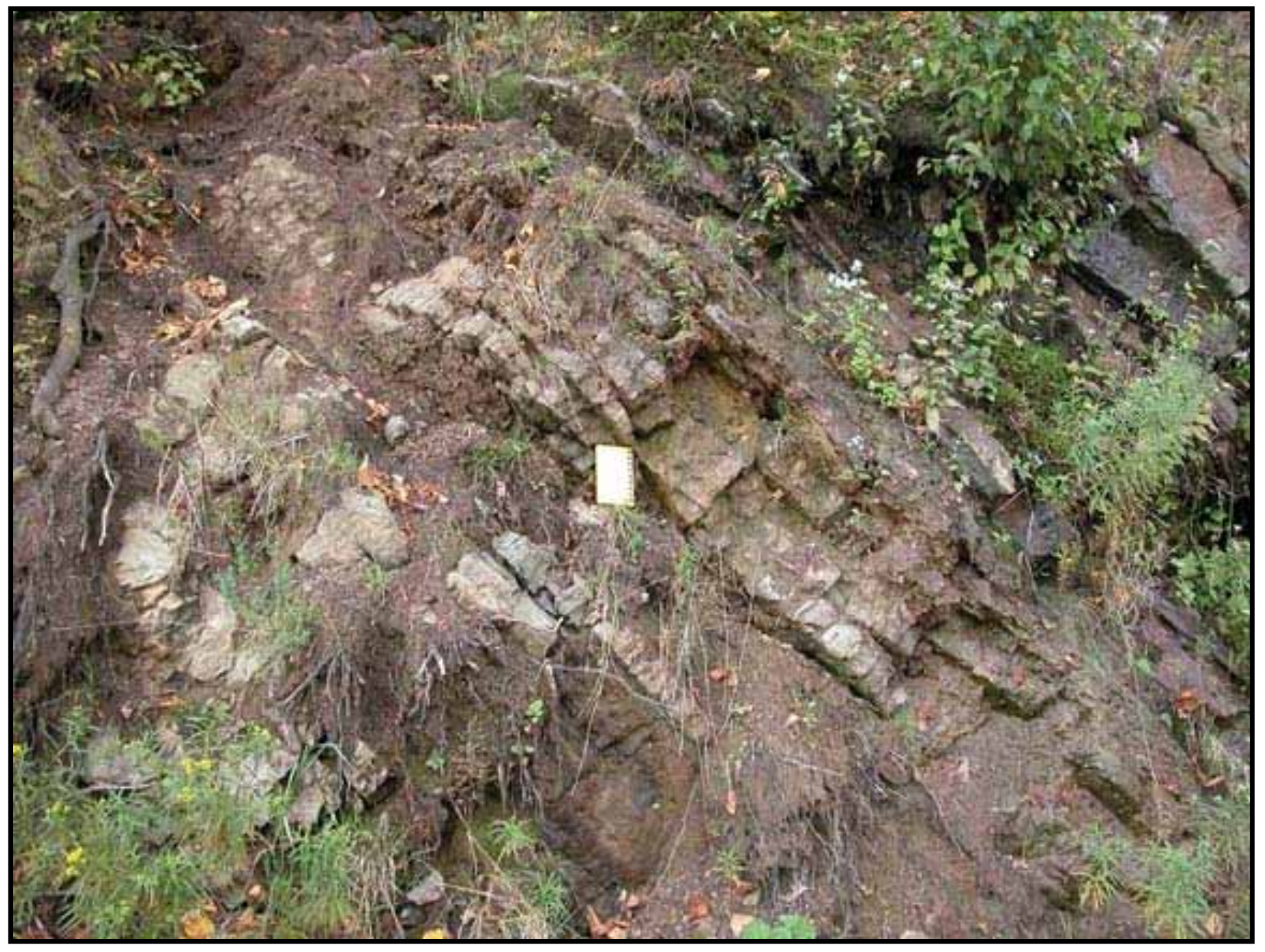

Figure 55. Photo ID \#1096: Photo shows sandstone beds thickening upward in Units $10 \& 11$ at LaVale, notebook for scale. 
(Fig. 56). No sedimentary structures were observed in outcrop for these units. Coalified plant debris and tree bark are identified as are bioturbation and Skolithos. Bjerstedt (1987) also identified Planolites in this facies.

The remainder of the bayhead-delta facies is characterized by interbedded shale, siltstone, and rare sandstone. Color of the shale is purple to red or gray to black. Plant debris is generally very abundant, and root traces are present. Mud cracks and bivalves are also observed. Sandstones are fine- to very fine-grained and 2-4 m thick with local scour base. Bedding ranges from medium to massive at top. The sandstone shows small-scale cross-stratification, horizontal stratification, and ripples. Plant debris is abundant throughout.

Interpretation - A bayhead-delta is defined as a fluvial-dominated delta that progrades into a semi-enclosed, marine-influenced body of water (Nichol, 1991; Dalrymple et al., 1992; cited in Nichol, 1997). The bayhead delta at LaVale and Finzel is characterized by scour-based sandstones with fining-upward trend interpreted as distributary channels, and by thickly bedded coarsening-upward units interpreted as distributary mouth bars and crevasse splays.

Tidally influenced distributary-channel sandstones have erosional scour base with basal lag of shale clasts, are medium- to fine-grained (fining-upward succession), and contain interbeds of shale toward the top. The dominant sedimentary structures are large-scale planar and trough cross-stratification, small-scale ripple bedding, and flaser bedding. Internal channelized bedforms indicate the repeated filling of channels followed by renewed erosion. These bedforms appear to be small channels that scoured into one another. Channels also contain thinly interbedded coal seams signifying a temporary abandonment of the channel. Slump blocks encased in sandstone show that mass wasting was occurring as channels migrated laterally. Root traces suggest the environment was locally colonized by plants, whereas 


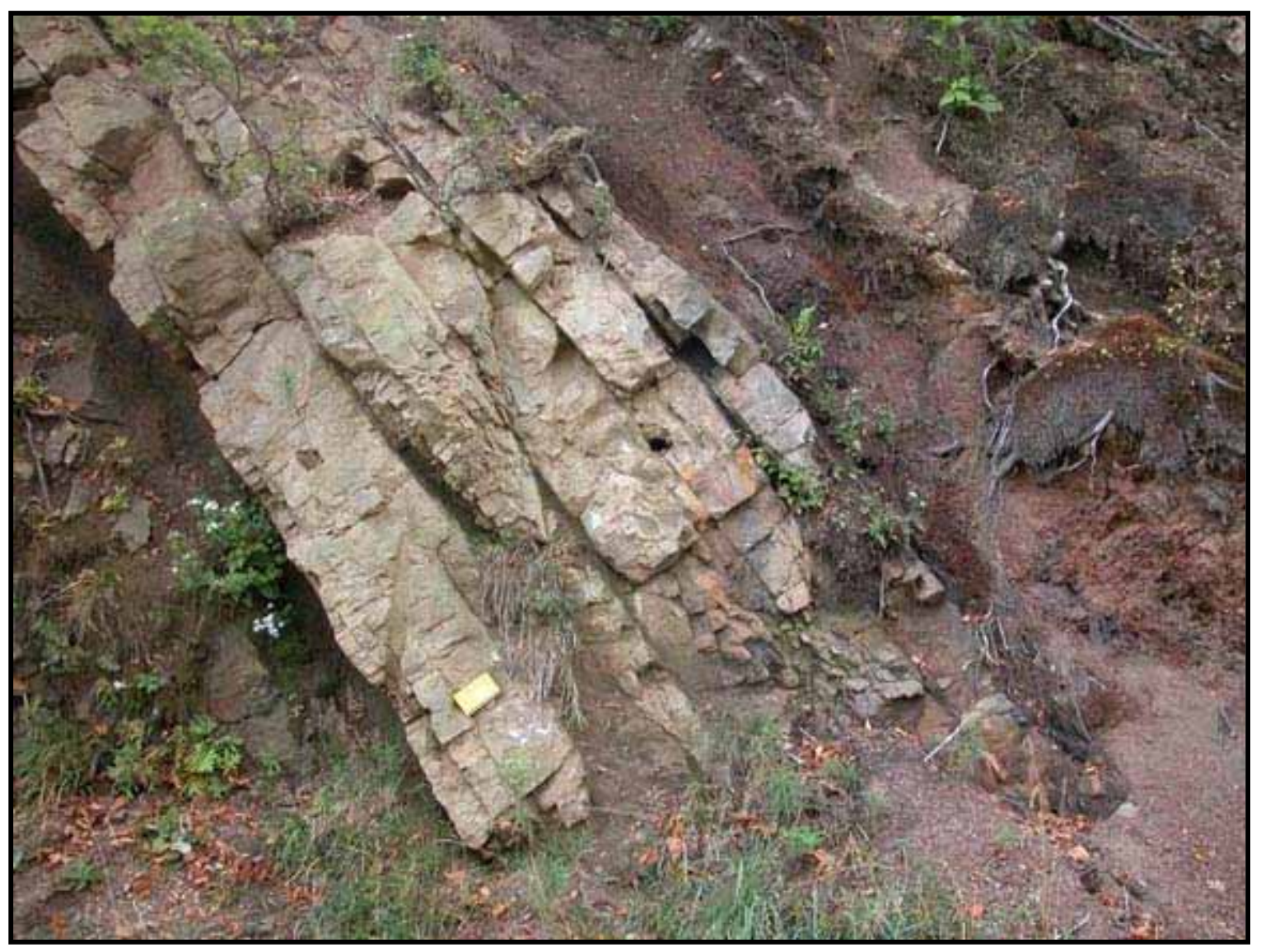

Figure 56. Photo ID \#1097: Photo shows a sharp basal contact of Unit 13 at LaVale, notebook for scale. 
bioturbation and Skolithos accompanied by flaser bedding suggests a marine influence (Nichol et al, 1997).

The distributary-mouth bar at LaVale consists of sandstone beds that coarsen from fineto medium-grained and thicken upward. The base of the mouth bar is sharp but locally erosional. Nichol et al. (1997) interpreted similar massive silty sand with coarsening-upward cycles as a record of subtidal distributary-mouth-bars of the modern Hawkesbury River bayhead delta of New South Wales, Australia. The presence of bioturbation and Skolithos in the Rockwell mouthbar sandstone indicates a marine influence.

Overbank deposits can be thick, as much as $7 \mathrm{~m}$, and are comprised of deep red to dark gray sandy mudstone and shale. These deposits may be thinly laminated and contain root traces, plant debris, and coaly shale, indicating a low-energy environment with luxurious plant growth and high water table. Purple to red colored shale indicates more arid conditions, and mudcracks suggest subaerial exposure. Interbedded with the overbank mud are crevasse splays. Crevassesplay deposits alternate between shale, siltstone, and sandstone but coarsen upward from a sharp basal contact. They also have abundant plant debris and ripple marks on bedding surfaces. During floods, crevasse splays frequently spilled onto the flood plain, resulting in thin interbeds of sandstone.

\section{Lacustrine}

Lake Beach

Description - At the Crystal Spring outcrop there are three prominent sandstone bodies (Units 2, 5, \& 9) that range from 7 to $9 \mathrm{~m}$ thick. Grain size is fine to medium, and bedding, very thin to very thick. The basal contact is sharp to gradational with locally developed load casts 
(Fig. 57 and 58). Some sandstones are laminated with climbing ripples. Other sedimentary structures include horizontal stratification, ripples on bedding surfaces (Fig. 59), and low-angle cross-stratification.

\section{Lake Bottom}

Description - This facies is characterized by interbedded siltstone and shale with occasional fine-grained sandstone. The dominant sedimentary structure is horizontal lamination (Fig. 60 and 61), a feature so characteristic that Sevon (1969) labeled these rocks "laminite". Ripples occur on some bedding surfaces. Diapiric structures (Fig. 62) appear within the finely laminated shale, produced by soft-sediment deformation of the interbedded diamictite.

Interpretation - Laminated sandstone with sharp basal contacts and climbing ripples are interpreted as deposits of a lake beach or sand flat deposits. Lake sediment is typically derived from rivers, and coarser material deposited along lake shores, particularly near river mouths. Thick sandstones accumulated during periods of rapidly falling lake level or lake infilling. Climbing ripples indicate a high sedimentation rate. Horizontal lamination, ripples, and lowangle cross-bedding are all typical of a beach deposit (Reading, 1996). Laminations indicate an upper flow regime, ripples indicate small-scale daily waves, and load casts are the result of rapid sedimentation.

Fine-grained sediment, consisting of interbedded siltstone and shale with occasional sandstone, is interpreted as the lake bottom. The sandstone was deposited in deeper water by bottom currents as indicated by the presence of ripple marks. Clay and siltstone interbeds are the result of mud particles settling from suspension. Lamination is caused by the frequent on-andoff sedimentation that is typical of lake deposition. The dominance of horizontal lamination and 


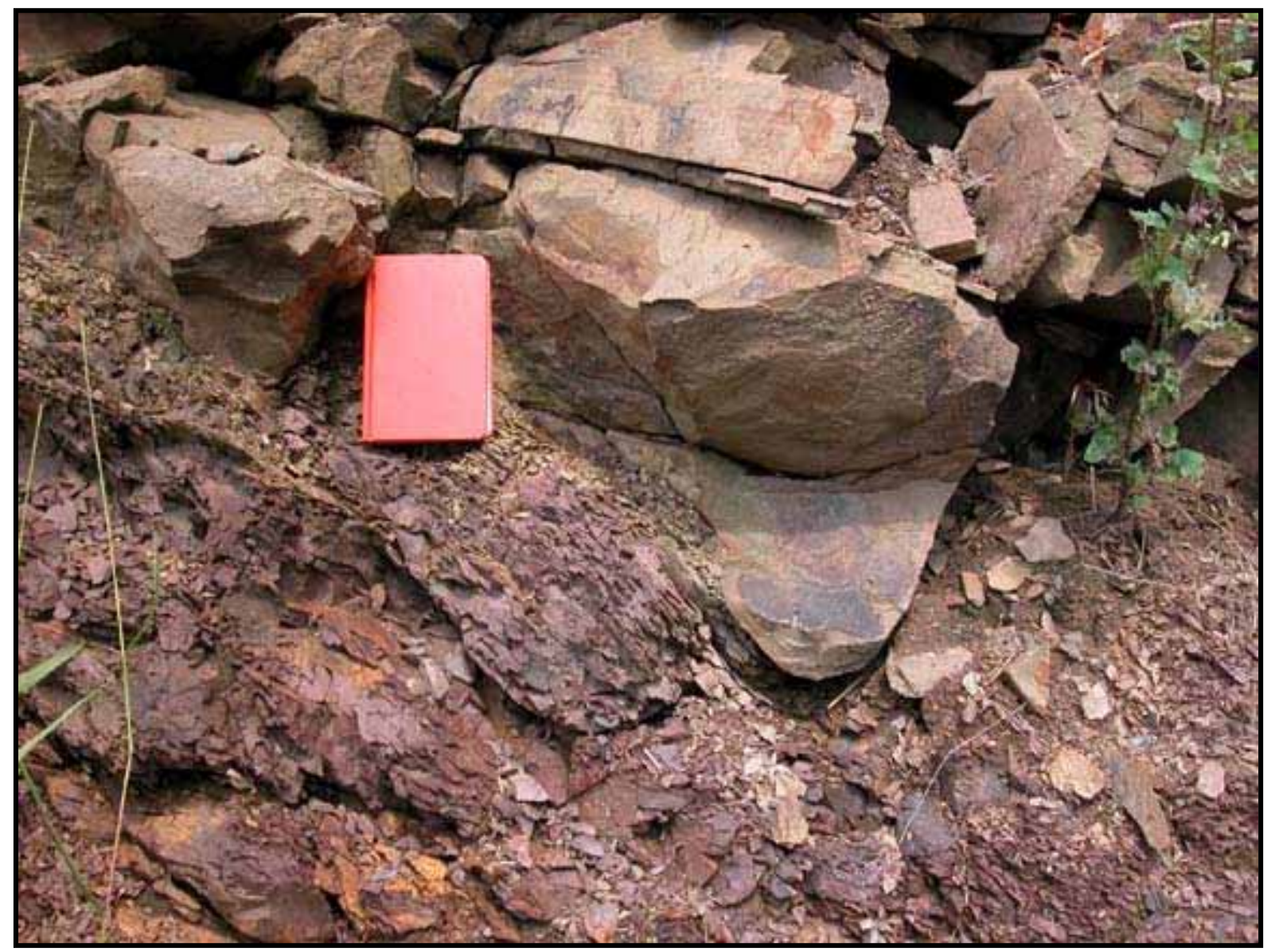

Figure 57. Photo ID \#1128: Photo shows locally developed load casts in Unit 1 at Crystal Spring. 


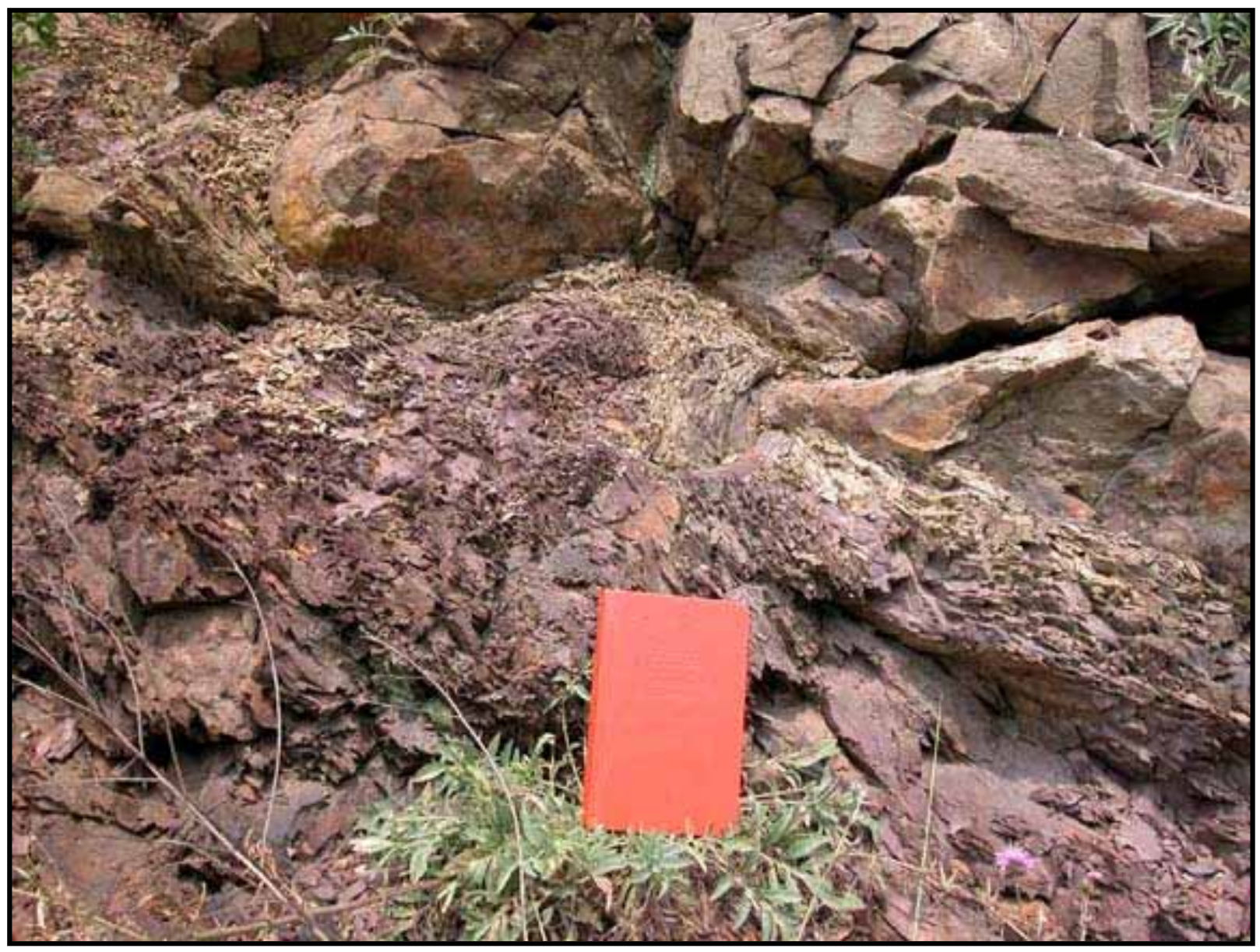

Figure 58. Photo ID \#1129: Photo shows a sharp basal contact of Unit 1 with the underlying Hampshire at Crystal Spring. Note the shale is squeezed up into the overlying sandstone. 


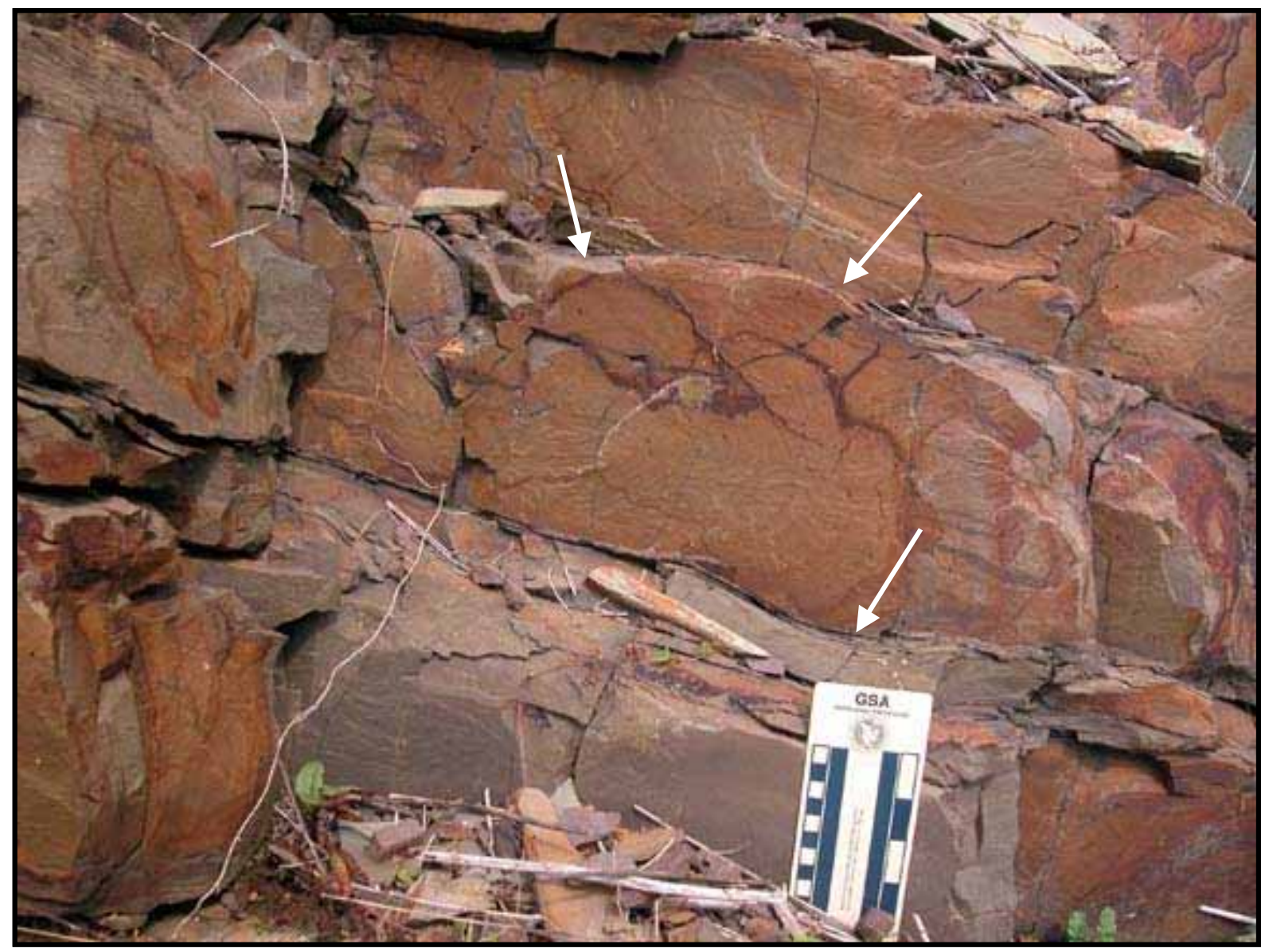

Figure 59. Photo ID \#1132: Photo shows a cross-sectional view of ripple bedding (indicated by arrows) in the sandstone of Unit 5 at Crystal Spring. 


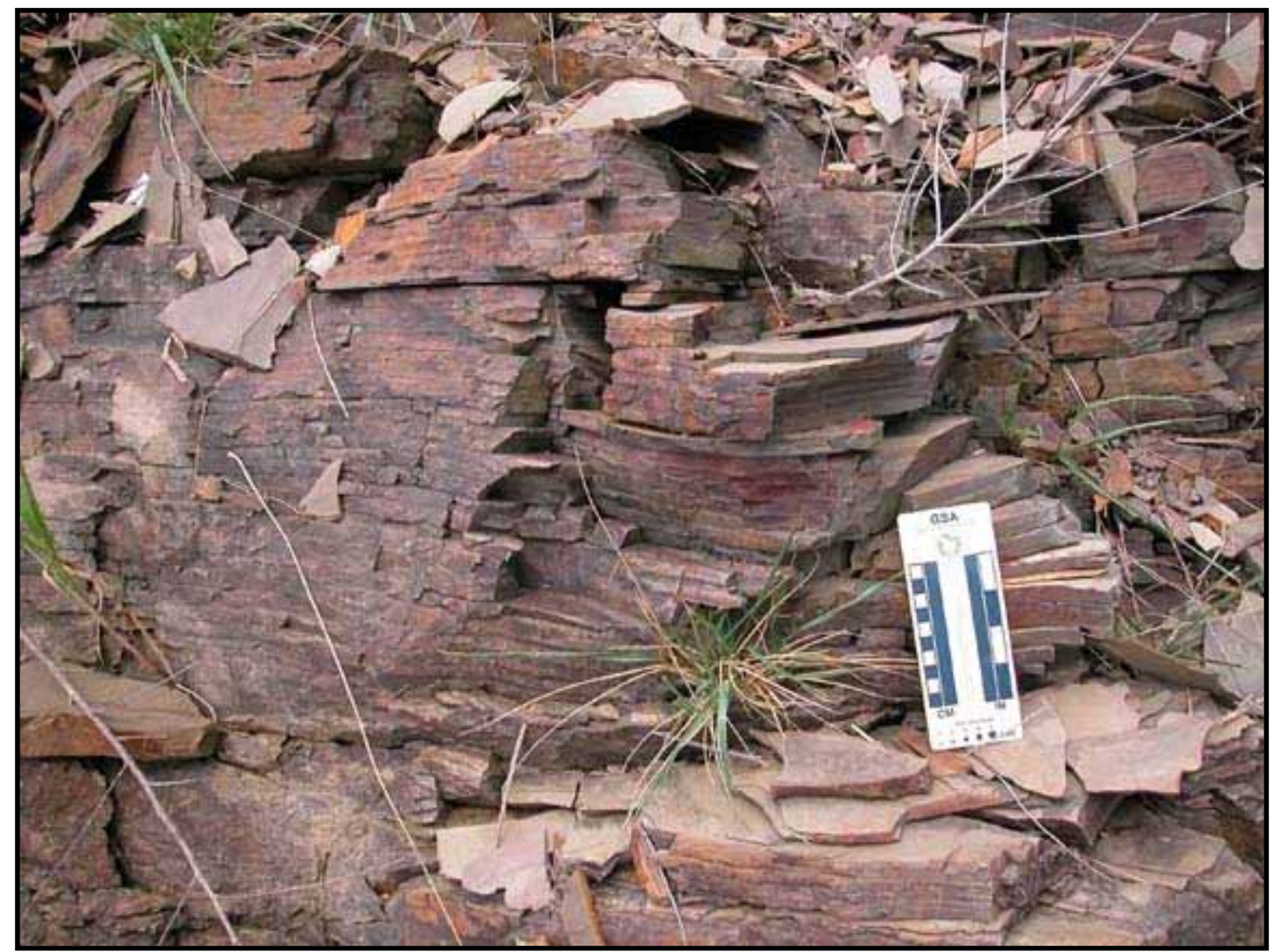

Figure 60. Photo ID \#1136: Photo shows a laminated siltstone "laminite" in Unit 5 at Crystal Spring. 


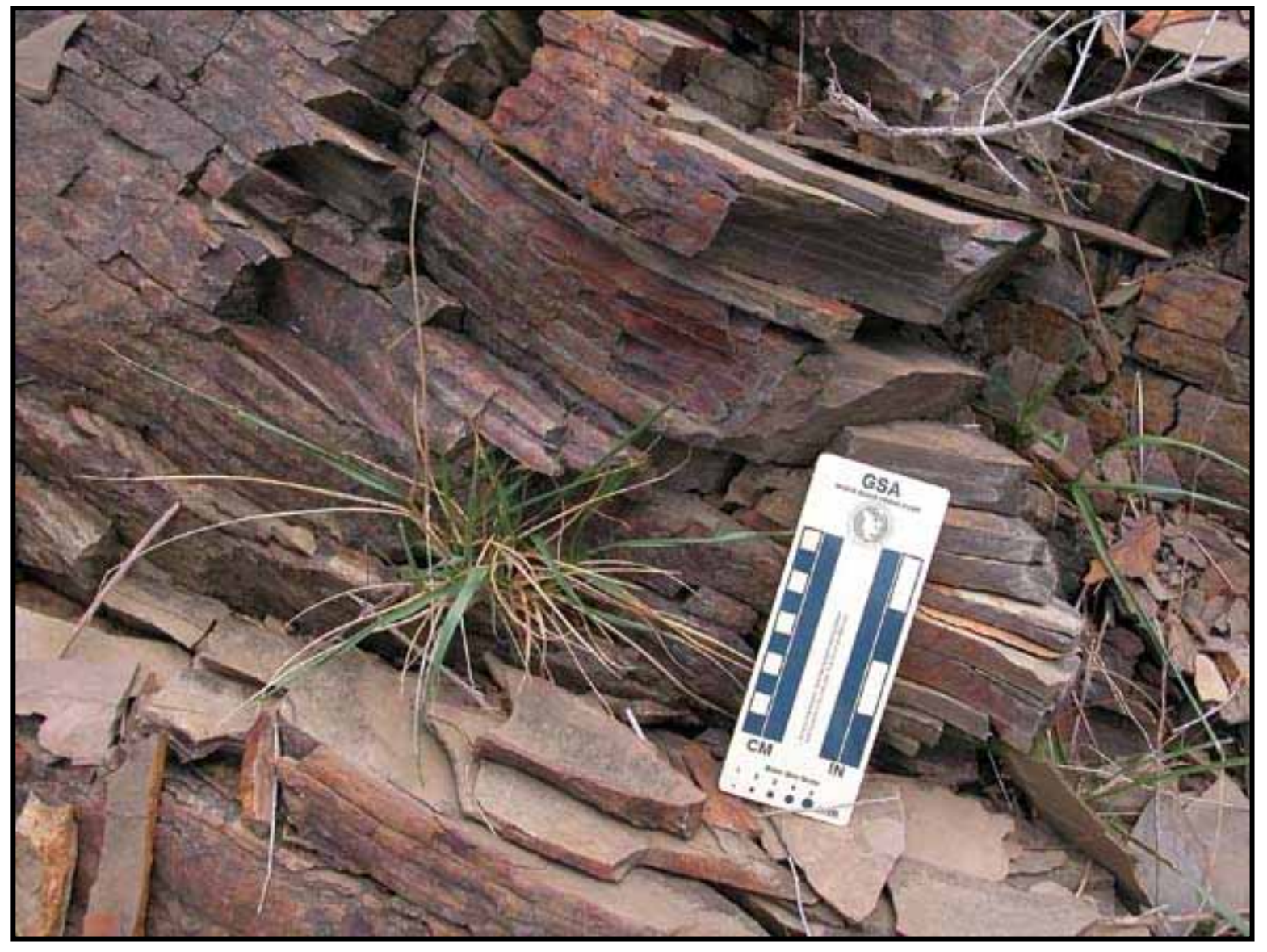

Figure 61. Photo ID \#1137: Photos shows a close-up view of the laminite of Unit 5 at Crystal Spring. 


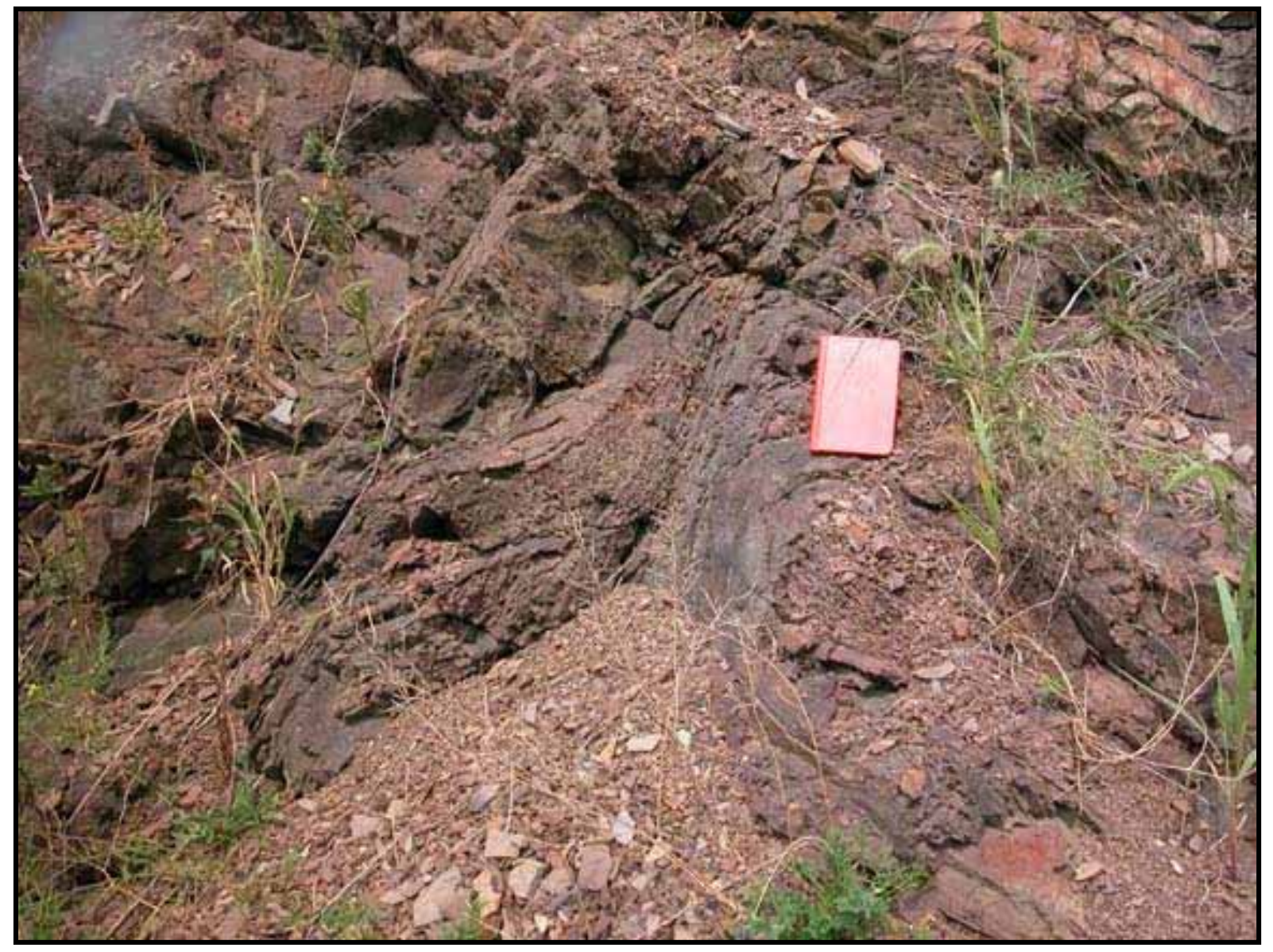

Figure 62. Photo ID \#1130: Photo shows the diaperic structures in a shale bed of Unit 11 just above the diamictite at Crystal Spring. 
absence of bioturbation indicates very low-energy conditions with restricted circulation in the lake bottom.

\section{Fluvial}

This basal section was not measured because the Maryland Survey now prohibits anyone from walking along the outcrop on the shoulder of I-68 eastbound. Therefore, this section is summarized from Suter (1991)

Description - The lower $17 \mathrm{~m}$ at the Sideling Hill outcrop consist predominantly of sandstone bodies 1-2 m thick with a scour base and channel-shape morphology. The average grain size is medium- to coarse-sand with channel lags. The basal lag commonly contains quartz pebbles, shale clasts, and plant debris. Chief sedimentary structures are trough cross-bedding, and horizontal lamination. Some sandstone beds contain mica flakes, and most have plant debris scattered throughout. Shale interbeds are mostly covered; they are commonly black to gray, fissile to laminted, and contain plant fragments and pyrite nodules.

Interpretation - Sandstone with scour base and channel lags are interpreted as fluvial channels. The basal lag deposit consists of typical coarse-grained thalweg material that a river moved at maximum stream velocity. Trough cross-bedding and horizontal laminations are preserved together in point-bar sequences. Fine-grained sediment was deposited on the floodplain during flood stage. Considerable amounts of plant debris is mixed with the finer sediment in the floodplain deposits (Boggs, 1995). 


\section{Diamictite}

Interpretation of the diamictite is a controversial topic and beyond the scope of this study. Therefore, this section is summarized from Suter (1991) and included here for the sake of completion.

Description - The diamictite is a pebbly mudstone and pebbly sandstone in beds from 2 - $11 \mathrm{~m}$ thick. Coarse grains are matrix supported. The martrix ranges from mud to very finegrained sand. The typical color of the matrix is red to red-brown when fresh and brown when weathered. Clasts consist of shale, sandstone, igneous rocks, volcanic rocks, chert, quartz, and possibly dolomite. Clasts are subangular to subrounded with no preferred orientation (Fig. 63), and they make up 1-7 \% of the rock by volume. Typical clast size is $5 \mathrm{~mm}$ to $2 \mathrm{~cm}$ with a maximum of $25 \mathrm{~cm}$ (Fig. 64). The diamictite is generally massive and structureless (Fig. 65) but does have interbeds of laminated shale, red shale, and siltstone. Soft-sediment deformation structures, such as flow-rolls or diapirs, are observed in the diamictite. Contacts are conformable with units both above and below.

Interpretation - Previous authors have suggested the diamictite was produced by debris flows, either subaqueous-lacustrine or subaqueous-marine, and probably related to some Acadian tectonic event (Sevon, 1969; Bjerstedt, 1986; Berg, 1999). In contrast, Blaine et al. (2002) thought the diamictite to be of a glacial or periglacial origin (based on the matrix-supported texture, clasts with striated facets, and overlying varve-like laminite). Sevon (1969) described the diamictite as a tillite-like rock of nonglacial origin, and Berg (1999) reluctantly dismissed a glacial origin because of its equatorial paleolatitude.

The diamictite was interpreted by Suter (1991) as the product of both viscous and dilute debris flows. Viscous debris flows are distinguished by their silt to coarse- sand matrix, massive bedding, and large clast size (mean $1.5 \mathrm{~cm}$ ). Thin-section petrography reveals viscous flows 
have only $27 \%$ illite matrix compared to $60 \%$ illite matrix of the dilute debris flow. Viscous debris flows exhibit laminations, have larger clasts, and lack significant water saturation. Lack of grading, coarse-grained matrix, and a large mean grain size is attributed to the decrease in water content. Characteristics of dilute debris flows include a random orientation and distribution of clasts, mud-rich matrix, smaller average clast size, smaller average percentage of clasts, rare stratification, and minor grading. Dilute debris flows are interpreted as runout deposits of more viscous flows. Runout deposits are caused by gravity deposition of waterconcentrated slurries during the waning of a viscous flow. 


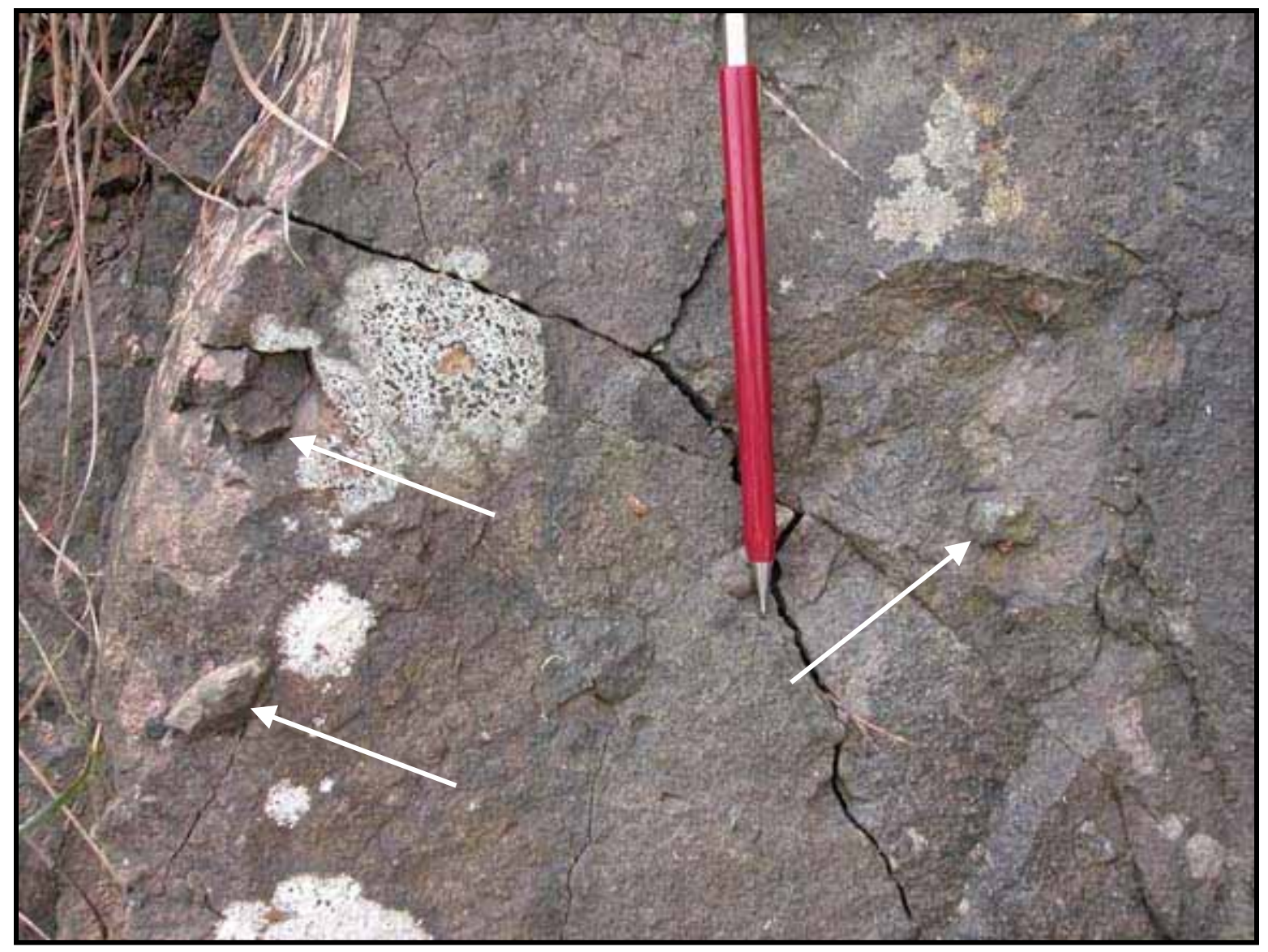

Figure 63. Photo ID \#1103: Photo shows clasts (indicated by arrows) in the diamictite of Unit 23 at LaVale. 


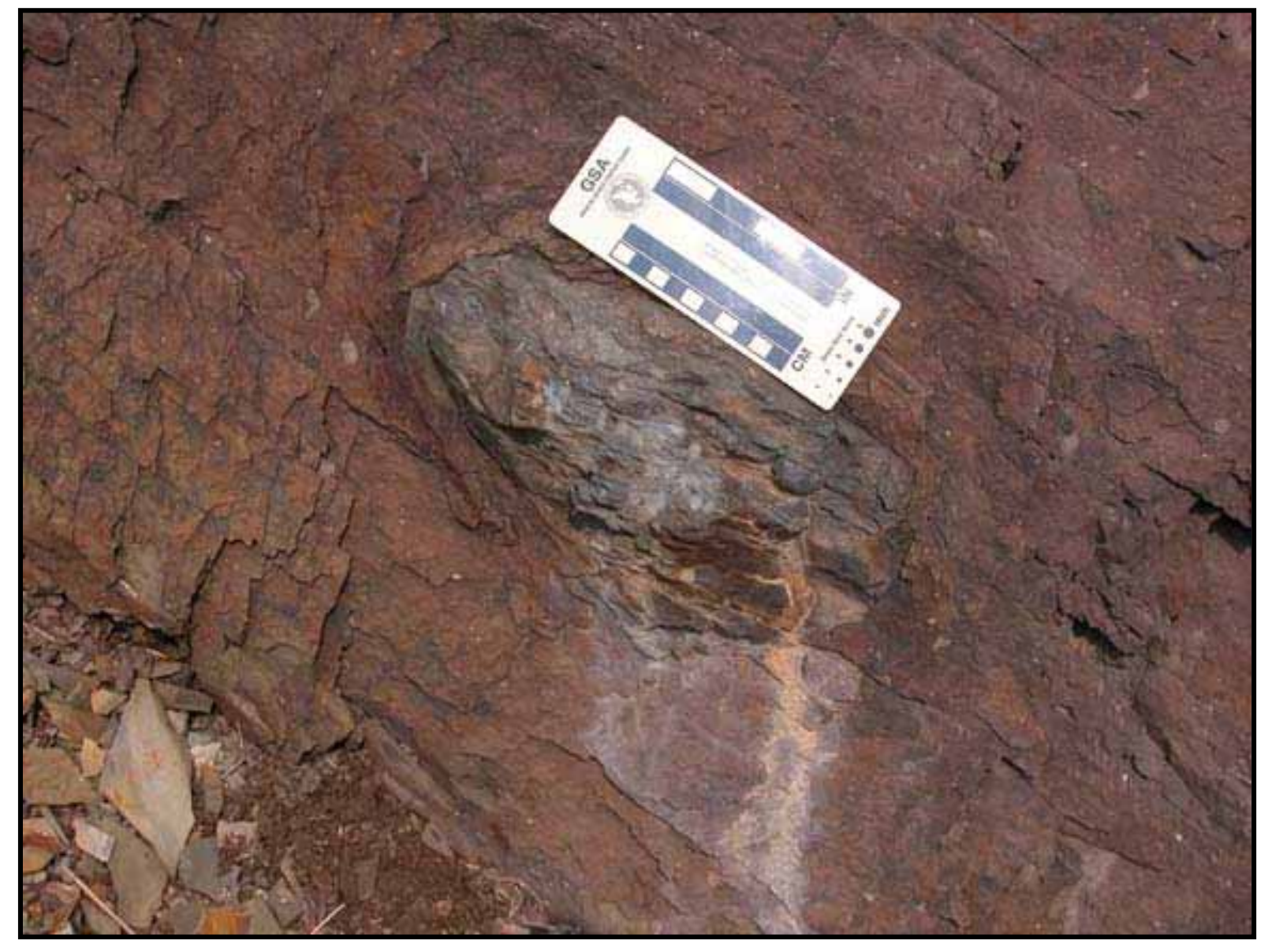

Figure 64. Photo ID \#1131: Photo shows a large clast in the diamictite of Unit 6 at Crystal Spring. 


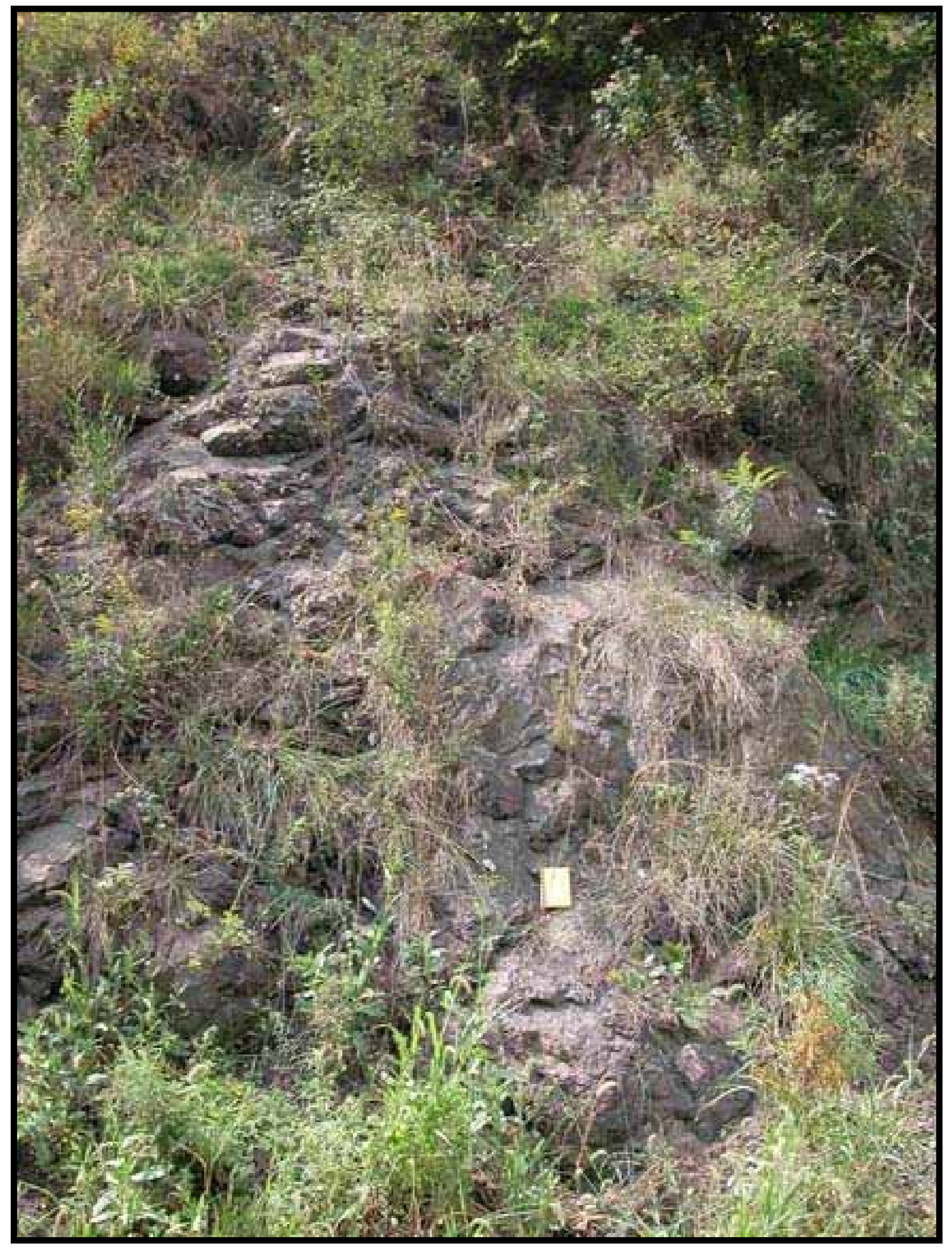

Figure 65. Photo ID \#1102: Photo shows the massive and structureless form of the diamictite of Unit 23 at LaVale, notebook for scale. 


\section{PALEOGEOGRAPHY}

The Upper Devonian Hampshire (Catskill) Formation in northern West Virginia and western Maryland is generally interpreted as coastal-plain red beds. Development of the Catskill coastal plain was in response to Acadian orogenic activity during the Middle and Late Devonian (Sevon, 1985). The source area for the Catskill sediments was the eastern Acadian Mountains, consisting of uplifted metamorphic and sedimentary rocks of Precambrian, Cambrian, and Ordovician age (Dennison et. al., 1986). Facies of the Catskill delta begin with a complex sequence of marine-nonmarine transitional environments passing upwards to meandering- and braided-stream deposits. Meandering streams, comprised mostly of fining-upward sequences, make up the bulk of the delta-plain facies. Sediment was deposited on a low-gradient plain by streams with a shallow channel, high sinuosity, and large flood basin. Typically coarse-grained channel sandstone grades upward into red siltstone and mudstone of the overbank. Calcareous nodules, small burrows, rootlets, plant fragments, and dessication cracks are common. Crevasse splays are evident as thin interbedded sandstone scattered throughout the sequence. This coastal plain was alternately emergent and submergent in response to relative sea-level change (Dennison et.al., 1986), and the region was under the influence of southeast trade winds in a tropical-dry or savannah-like climate (Woodrow, 1985). Rainfall was seasonal and extensive dry periods probably occurred annually. Stream erosion, however, was an important factor on the alluvial plain producing incised valleys, especially in areas nearest to the Acadian Mountains (Sevon, 1985; Cotter and Driese, 1998).

The paleogeography in West Virginia, Maryland, and south-central Pennsylvania at the beginning of Rockwell-Price deposition is not well known but has been recognized as a coastal 
embayment (Fig. 66; Bjerstedt \& Kammer, 1988). This study is interpreting the Oswayo Member as a back-bar lagoonal deposit but it may in fact be part of an estuary. Whether or not the rocks are lagoonal or estuarine in origin would be difficult to recognize on outcrop.

The mouth of the embayment is represented in the rocks at Rowlesburg, whereas the head of the embayment was near Crystal Spring. West of Rowlesburg, Boswell (1985) interpreted a thick north-south sandstone trend in the West Virginia subsurface as offshore bars that acted as a barrier to normal-marine circulation in the embayment or lagoon (Bjerstedt \& Kammer, 1988). The lower section of the Rowlesburg outcrop (Oswayo Member) reflects the marine-influenced outer lagoon with tidal channels, washover sands, and subtidal mud that was later transgressed by barrier islands from the west (Fig. 67). Water depth was most likely shallow (a few meters), but tidal channels permitted good circulation in the outer lagoon as indicated by a diverse assemblage of trace and body fossils dominated by brachiopods.

Landward of the embayment mouth was a river-influenced inner lagoon characterized by shallower water depths and restricted circulation. In this lagoon there were fewer trace fossils and almost no body fossils; the rare Lingula brachiopods indicate brackish conditions. The cause of restricted circulation and brackish salinity in this area of the lagoon is two-fold. The inner lagoon was partly closed by barrier islands, and the shallow water depth dampened wave and current energy in the far reaches of the lagoon. The inner lagoon was also influenced by rapid deposition of fluvial, distributary, and tidal-channel sediments, which also created a stressful environment for marine fauna. Root traces and paleosols indicate occasional periods of subaerial exposure. Along the coastline was a bayhead-delta with distributary-mouth bars, tidally influenced distributary channels, and delta plain. Sand bars with sharp base and coarsening- 


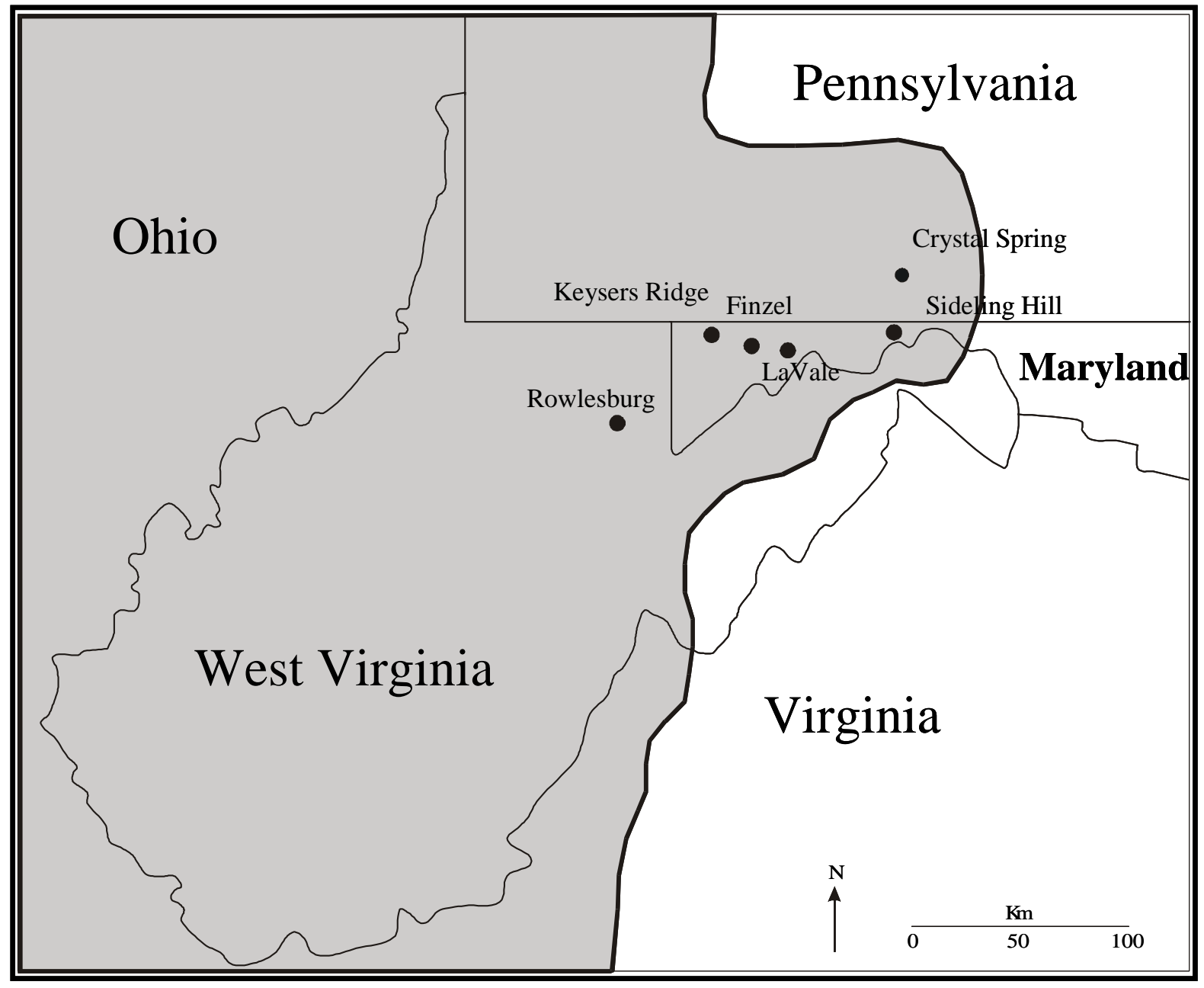

Figure 66. Location map showing the interpreted paleoshoreline (estimated maximum transgression of the Riddlesburg Sea shown in gray) in relation to the six outcrops in the study area. After Reger, 1927; Dennison et al., 1986; Bjerstedt \& Kammer, 1988; and Berg, 1999. 


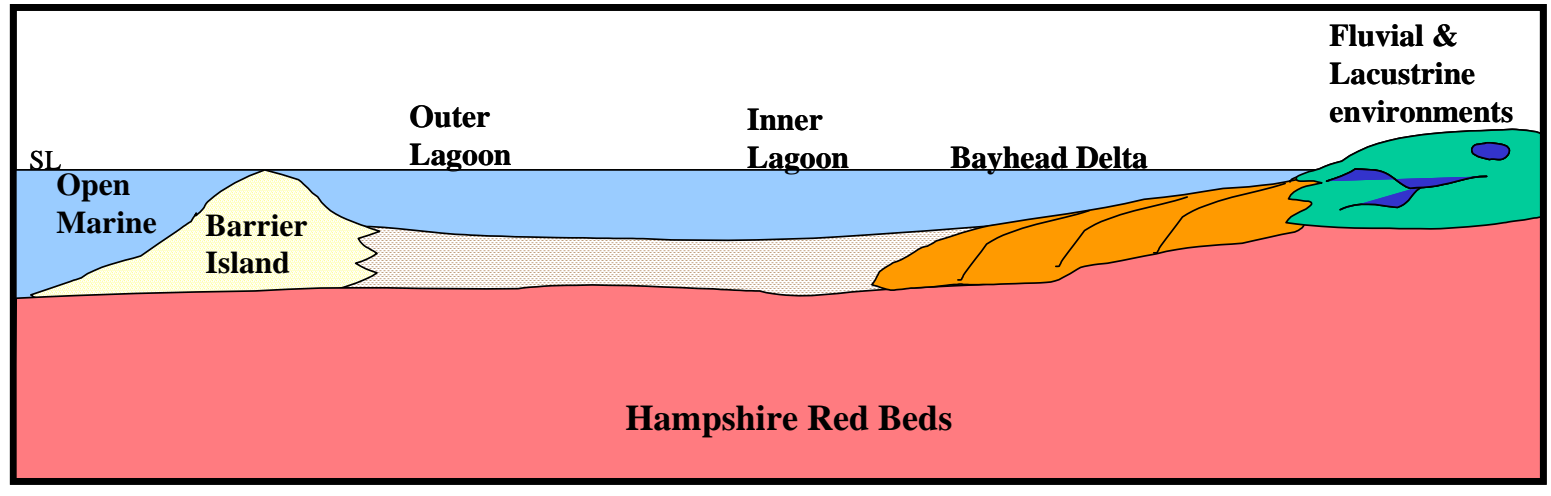

Figure 67. Diagram showing a simple cross-sectional profile of the interpreted depositional environments. No scale implied 
upward texture formed at the mouth of the distributary channels. Rockwell distributary-mouth bars also contain bioturbation and Skolithos burrows. Distributary channels exhibit minor tidal and marine influence (flaser bedding and Skolithos). The channels were repeatedly cut and filled, and lateral migration led to slumping of the banks. Temporarily the channels were abandoned and filled with peat (coal seams). Thick accumulations of red overbank mud were deposited adjacent to the distributary channels, and occasionally a crevasse splay spilled onto the flood plain.

Lakes and rivers occurred along the coast of the embayment. The easternmost outcrops at Crystal Spring and Sideling Hill have laminated shale of a lake center, sandstone with ripple marks of a lake beach, and fluvial channel sandstones with interbedded overbank shale. Also, there are relatively thick interbeds of diamictite. The diamictite may have originated as debris flows that flowed through the stream channels and into the lakes. The deeper part of the lake filled with laminated fine-grained sediment that settled from suspension. Infilling of the lake by fluvial sediment and debris flows decreased accommodation space, producing a sandy lake beach with climbing ripple marks and low-angle cross-beds. The beach sandstone has a sharp base signifying a rapid fall of relative lake level. Meandering rivers along the coastal edge of the embayment deposited the typical fining-upward sequence with scour-based channel sandstone grading upward into shaly overbank deposits. The sandstone displays trough cross-bedding and horizontal lamination, and abundant plant debris is present in the shale. 


\section{STRATIGRAPHIC INTERPRETATION}

The sedimentary model that is being proposed in this study depicts a coastal embayment approximately $175 \mathrm{~km}$ wide at the mouth and extending $150 \mathrm{~km}$ inland. Previous studies, such as Reger (1927), Berg and Edmonds (1979), Bjerstedt and Kammer (1988), and Berg (1999), have called this the Riddlesburg Embayment. All six of the outcrops measured and described in this present study are positioned along the axis of the embayment.

The contact between the Hampshire (or Catskill) and Rockwell Formations is probably unconformable. Berg (1999) identified the basal contact of the Spechty Kopf Formation (Rockwell equivalent in eastern Pennsylvania) as unconformable with the Catskill, and erosional relief is up to $100 \mathrm{~m}$ (Berg and Edmunds, 1979; Sevon, 1979). The Rockwell Formation itself is also separated from the Catskill by an unconformity in Fulton County and the surrounding area of south-central Pennsylvania. In addition, Bjerstedt and Kammer (1988) stated that the Rockwell unconformably overlies the Catskill/Hampshire Formation in Maryland, the West Virginia panhandle, and south-central Pennsylvania (1 m of relief at Crystal Spring, PA). On the other hand, (Brezinski, 1989) concluded that there is no evidence for an unconformity in Maryland. Dennison (1985) identified a major sea-level drop near the end of the Devonian, based on an abrupt basinward shift of nearshore-marine facies. The shoreline moved as far west as the Ohio River so that a large area of the Catskill deltaic complex was exposed. There is, however, no widespread erosion surface at this stratigraphic level in West Virginia and Maryland (Dennison et al., 1986). The base of the Rockwell in my study area is taken as a subtle unconformity and considered here to be a sequence boundary. The shoreline retreated basinward with significant erosion in eastern Pennsylvania (beneath the Spechty Kopf), decreasing rapidly in magnitude to the west (meter-scale erosional surface in Maryland), and a subtle erosional or 
nonerosional surface in West Virginia. The unconformity was then flooded with a following rise in relative sea-level: the Oswayo Member of the Rockwell-Price Formation.

The transgressive Oswayo Member was deposited in a coastal embayment located in western Maryland, south-central Pennsylvania, and the West Virginia panhandle (Fig. 68). Within this embayment the transgression is marked by an abrupt landward shift in Oswayo marine facies. From west to east the facies grade from marine-dominated outer lagoon, to riverinfluenced inner lagoon, to fluvial and lacustrine facies. Initially, during Oswayo time, the transgression was slow and sediment influx from the east generally kept pace with sea-level rise as evidenced by aggrading sedimentation of the bayhead delta at LaVale and Finzel.

The westernmost outcrop of Rowlesburg contains interbedded sandstone and shale of a marine-influenced outer-lagoon facies (Fig. 69). The lower section of the Oswayo Member comprises thick shale with thin beds and lenses of siltstone and sandstone. Alternation of shale, siltstone, and sandstone illustrates a cyclicity of wave action behind the barrier island. Coarsergrained beds with scattered plant debris, isolated trace and body fossils, and bioturbation represent deposition from storm washovers, whereas tidal-channel deposits are characterized by medium- to very fine-grained sandstone with scour base, channel lag, and a fining-upward sequence. Sandstone beds increase in number upward in the section signifying a shallowing of the lagoon. The number of washover sandstones increase as well, illustrating that the barrier island was retreating landward into the lagoon. Thin conglomeratic beds near the top of the Oswayo reflect slight falls of relative sea-level superimposed on the overall transgression.

To the east at LaVale and Finzel, the Oswayo Member represents a river-influenced inner-lagoon facies (Fig. 69). The section is dominated by restricted-subtidal facies and distributary channels and mouth bars of a bayhead delta. The lower $20 \mathrm{~m}$ is interpreted as the 


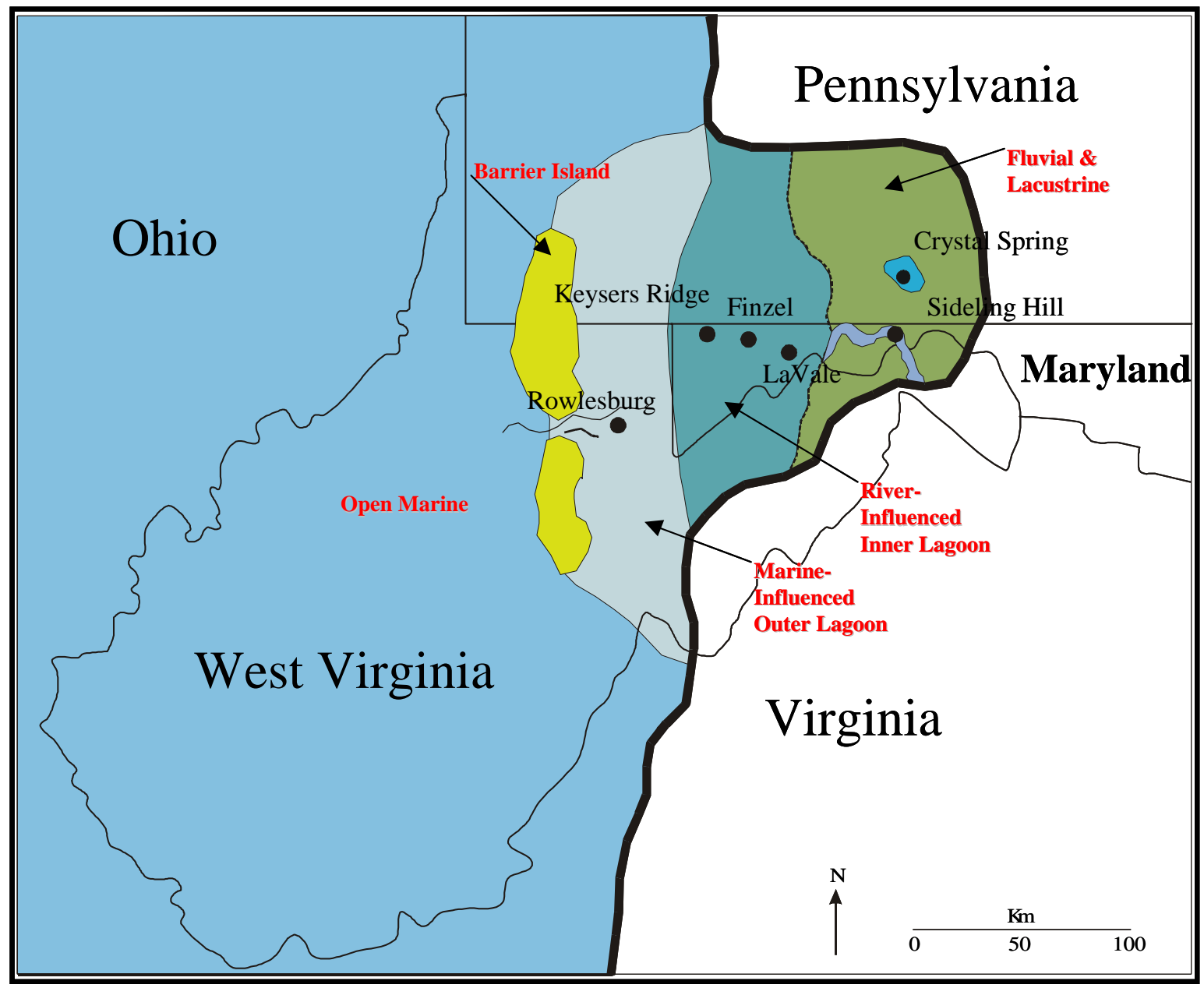

Figure 68. Map showing the interpreted transgression of the barrier island at Time 1. Map illustrates the position of the barrier islands just west of Rowlesburg. 


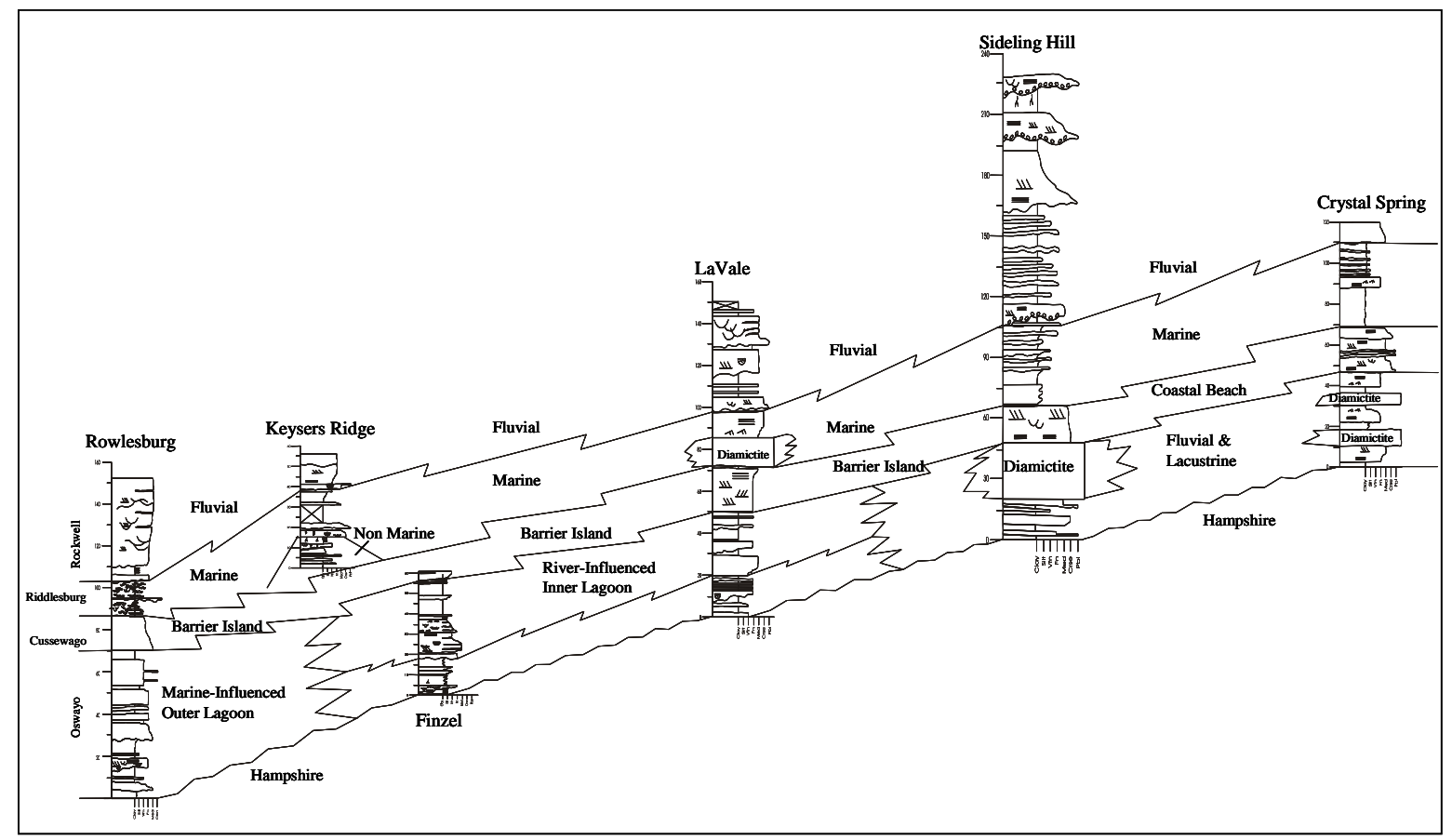

Figure 69A. Lithostratigraphic cross-section of the six outcrops in the study area from Rowlesburg, WV to Crystal Spring, PA. Cross-section illustrates this studies preferred correlation of the Cussewago sandstone assuming the diamictites are diachronous.

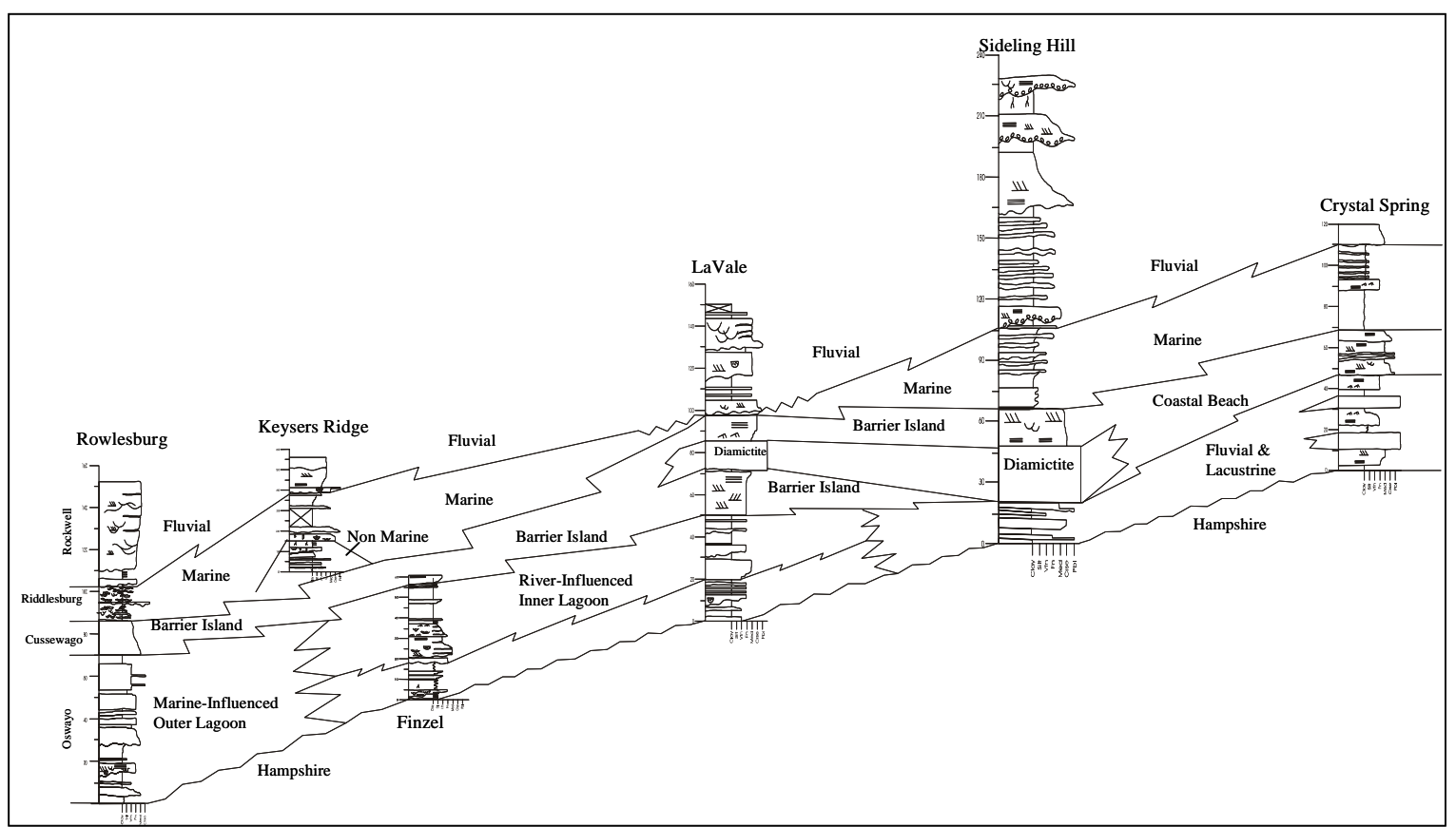

Figure 69B. Lithostratigraphic cross-section of the six outcrops in the study area from Rowlesburg, WV to Crystal Spring, PA. Cross-section illustrates an alternative interpretation where the diamictite may be a synchronous unit. 
restricted-subtidal facies, dominated by thick shale packages with thinly bedded siltstone and sandstone. The shale packages represent quiet times in a low-energy environment when finegrained sediment was settling from suspension. The interbedded sandstone and siltstone are the product of tidal channels. Locally these subtidal sediments contain root traces and paleosols indicating temporary subaerial exposure and slight falls of relative sea level.

Distributary channels and mouth bars are part of the aggrading bayhead delta (upper 48$55 \mathrm{~m}$ ) that temporarily kept pace with the marine transgression. Aggradation of the bayhead delta was caused by increased sediment supply from fluvial sources. Distributary channel sandstones have erosional scour bases with fining-upward trends, whereas distributary mouth bars are thickly bedded with a coarsening-upward trend. Marine or tidal influence is indicated by Skolithos, bioturbation, bivalves, and flaser bedding. Delta-plain mud is red to black with mud cracks, plant debris, paleosols, and sometimes is coaly. The delta plain was subjected to fluctuating water table conditions: red mud indicates a dry climate with a low water table and black mud, a wetter climate with a high water table.

East of the bayhead delta are the dominantly fluvial and lacustrine sediments at Sideling Hill and Crystal Spring, respectively (Fig. 69). These terrestrial facies lack any indication of marine influence. The lower $17 \mathrm{~m}$ of Sideling Hill comprises fluvial-channel sandstone and overbank shale. Stratigraphically above lies a thick section of stacked diamictite: debris flow following stream channels. Lacustrine sediments at Crystal Spring consist of laminated shale of the lake bottom and rippled sandstone of the beach facies. Diamictite, presumably debris flows, was deposited in the deeper portion of the lakes. There are two lacustrine sequences at Crystal Spring, one stacked on top of the other. Thick lake deposits formed as the water table was rising which may have been linked to the marine transgression. During the transgression, the water 
table rose allowing lakes to form. Laminated shale of the lake bottom is capped by beach sandstone, signifying a brief drop in the water table. The sharp contact suggests a rapidly falling lake level or lake infilling. Perhaps the two 20-m-thick lake successions relate to changes in relative sea level. Conglomeratic beds at Rowlesburg, paleosols at LaVale and Finzel, and the succession of lake deposits at Crystal Spring all suggest the general marine transgression was interrupted by aggrading delta sediments and brief falls of sea level.

The stratigraphically higher Cussewago member is interpreted as a barrier island that progressively transgressed the embayment. Initially the barrier island that closed off the shallow embayment was situated west of Rowlesburg (Fig. 68). During transgression the sand body migrated to the east onlaping both lagoon and terrestrial facies (Fig. 70). The base of the sandstone is a wave ravinement surface, a transgressive surface of erosion marking an abrupt landward shift in facies. The landward barrier migration is interpreted as rapid because everywhere the sandstone is transgressive, with no indication of aggrading or prograding sedimentation as occurs in the Oswayo below. As the barrier transgressed landward, it eventually became attatched to the coast near the head of the embayment (Figs. 71 and 72). The sandstone of Sideling Hill and Crystal Spring are interpreted as that of a coastal beach rather than barrier beach. A significant difference between the barrier sandstone to the west and coastal sandstone to the east is related to the presence of the lagoon. The barrier at Rowlesburg, Finzel, and LaVale enclosed a back-bar lagoon over which the barrier then migrated during the marine transgression. Once the barrier reached Sideling Hill and Crystal Spring, deeper into the embayment, there was no longer a lagoon behind. The sand became a coastal beach. Supporting evidence of this lateral facies change is that to the east the sandstone has fewer shale breaks, 


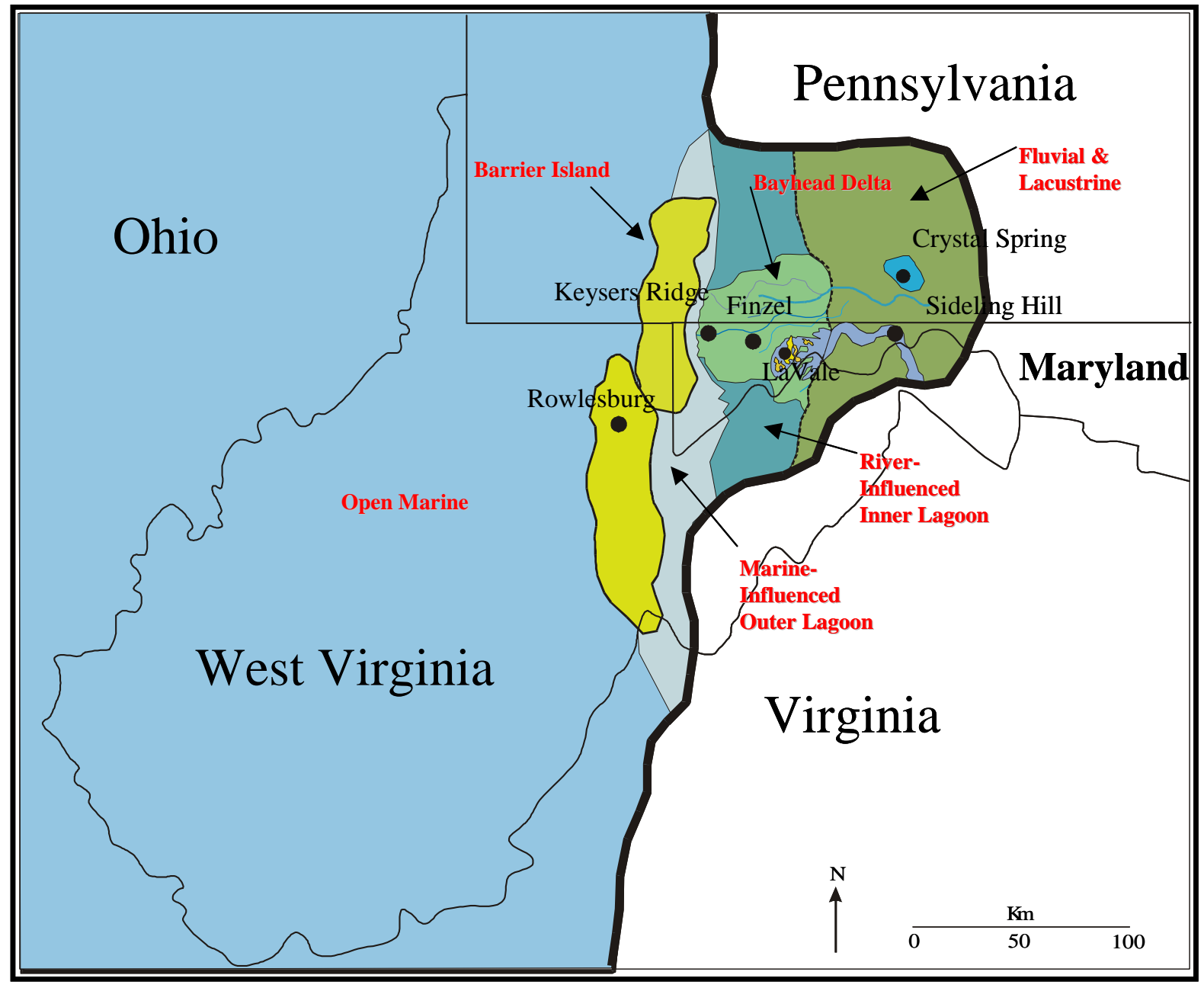

Figure 70. Map showing the interpreted transgression of the barrier island at Time 2. Map illustrates the barrier island being deposited at Rowlesburg and the bayhead delta to the east. 


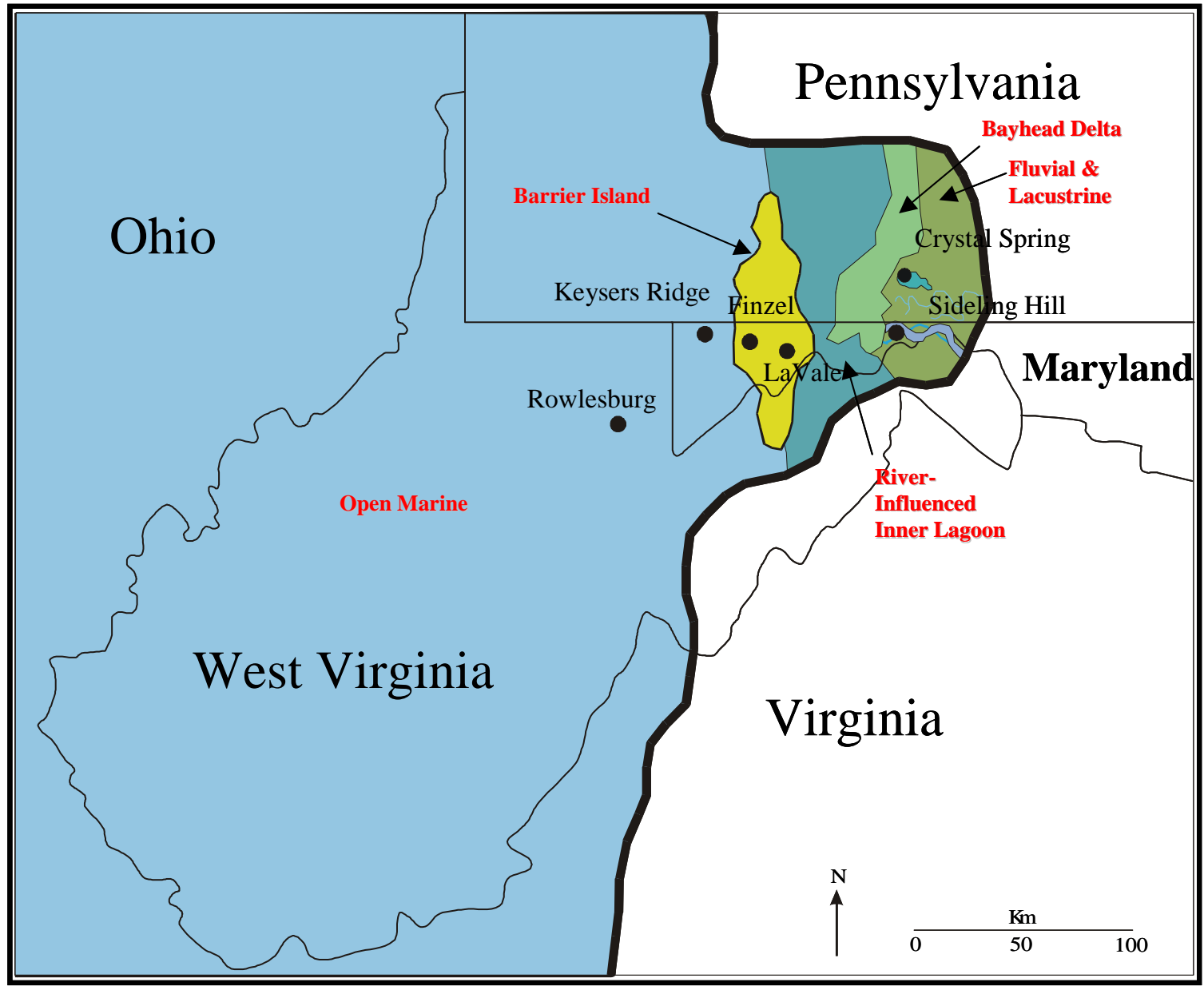

Figure 71. Map showing the interpreted transgression of the barrier island at Time 3. Map illustrates the barrier island being deposited at Finzel and LaVale. 


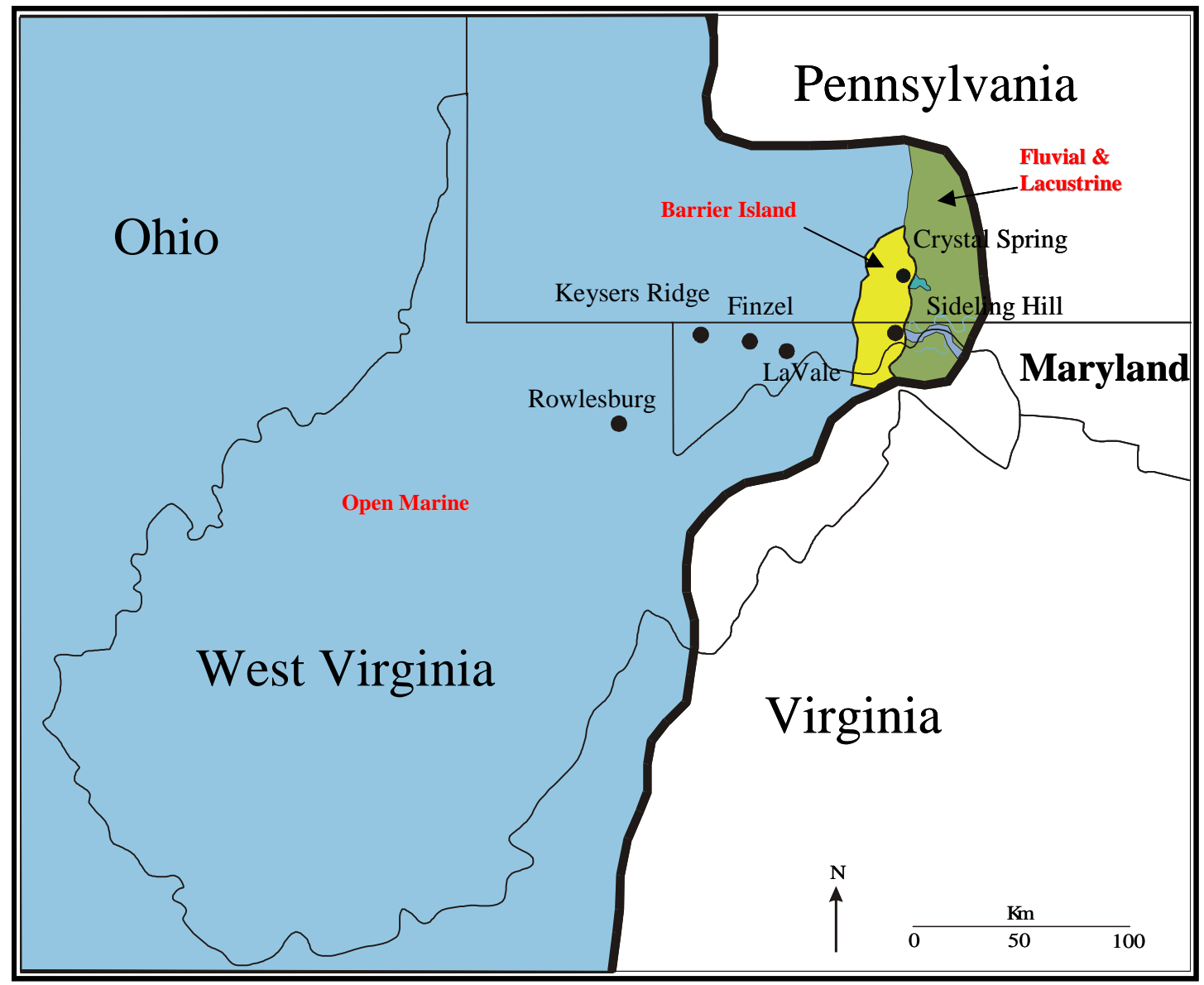

Figure 72. Map showing the interpreted transgression of the barrier island at Time 4. Map illustrates a coastal beach being deposited at Sideling Hill and Crystal Spring. 
fewer trace and body fossils, coarser grain size, and more pebbles. These characteristics suggest a proximity to the sediment source and higher sedimentation rate. The diamictites are diachronous in this interpretation (Fig 69A), however, Figure 69B shows the diamictites as synchronous, but that then requires an inferred unconformity at La Vale below the base of the fluvial sequence.

A modern analogue to this study is the work done by Dalrymple et. al (1992) on estuarine systems. Those authors defined estuary as "the seaward portion of a drowned valley system which receives sediment from both fluvial and marine sources...containing facies influenced by tide, wave, and fluvial processes”. Estuaries form during a relative sea-level rise. They begin to fill under slowly rising or stable sea level and remain flooded as sea level continues to rise. In a similar fashion, the embayment described in the present study is part of the latest Devonian-early Mississippian transgression that onlapped the Catskill coastal plain (Hampshire red beds). The bay of this study received sediment from both fluvial and marine sources, and the sediments were influenced by tide, wave, and fluvial processes.

Dalrymple et al (1992) uses a tripartite zonation model to explain the distribution of wave-dominated estuarine lithofacies. In their model three zones coexist: an outer zone dominated by marine processes (shallow nearshore marine), a low-energy central zone, and an inner river-dominated zone (seaward of the tidal limit). Facies in the outer zone include tidal channels, washover sands, and flood-tidal deltas. The inner zone comprises the bayhead delta. Net bed-load transport in the outer zone is landward and in the inner zone, seaward. As a result the central zone is an area of net convergence and a sediment sink, and usually the central zone contains the finest-grained bedload sediment. 
The mouth of the estuary is dominated by wave energy, and sediment typically travels along or onshore into the mouth, forming barriers, spits, and washovers. The barriers hinder wave energy inside the estuary; consequently only local wave action and tidal inlets allow for circulation behind the barrier. At the head of the estuary, fluvial energy is dominant but decreases seaward due to decreasing hydraulic gradient. The energy profile as described by Dalrymple et al (1992) has two maxima, one at the mouth (coarse-grained sediment) caused by wave action and one at the head (coarse-grained sediment) produced by river currents. These two maxima are separated by a significant energy minimum (fine-grained sediment) in the central section of the estuary.

A comparison of the study by Dalrymple et al (1992) with the present study of the Rockwell-Price finds many similarities. The facies, facies distribution, and interpreted processes described in this study correlate with the tripartite zonation model. Therefore, the stratigraphic interpretations of Dalrymple et al. (1992) - although applied to estuaries - can serve as a guide for interpretation of the Devonian-Mississippian embayment of my study.

The stratigraphic succession of facies (Fig. 73) begins with an erosional unconformity and flooding surface, a sequence boundary. The Oswayo Member of the Price-Rockwell Formation (the base of which is a flooding surface) marks the initial transgressive systems tract that overlies coastal-plain red beds of the Hampshire Formation (Fig. 74). The Oswayo Member is interpreted as being deposited during a slow transgression in which sediment accumulation generally kept pace with rising sea level. Coarse-grained sediments of the outer lagoon (corresponding to outer estuary of Zaitlin et al; 1994) were derived from the barrier island to the west of Rowlesburg. Tidal-channel and washover sandstones, totaling $70 \mathrm{~m}$, accumulated (aggraded) in the outer lagoon as the barrier island slowly migrated landward. Tidal ravinements 


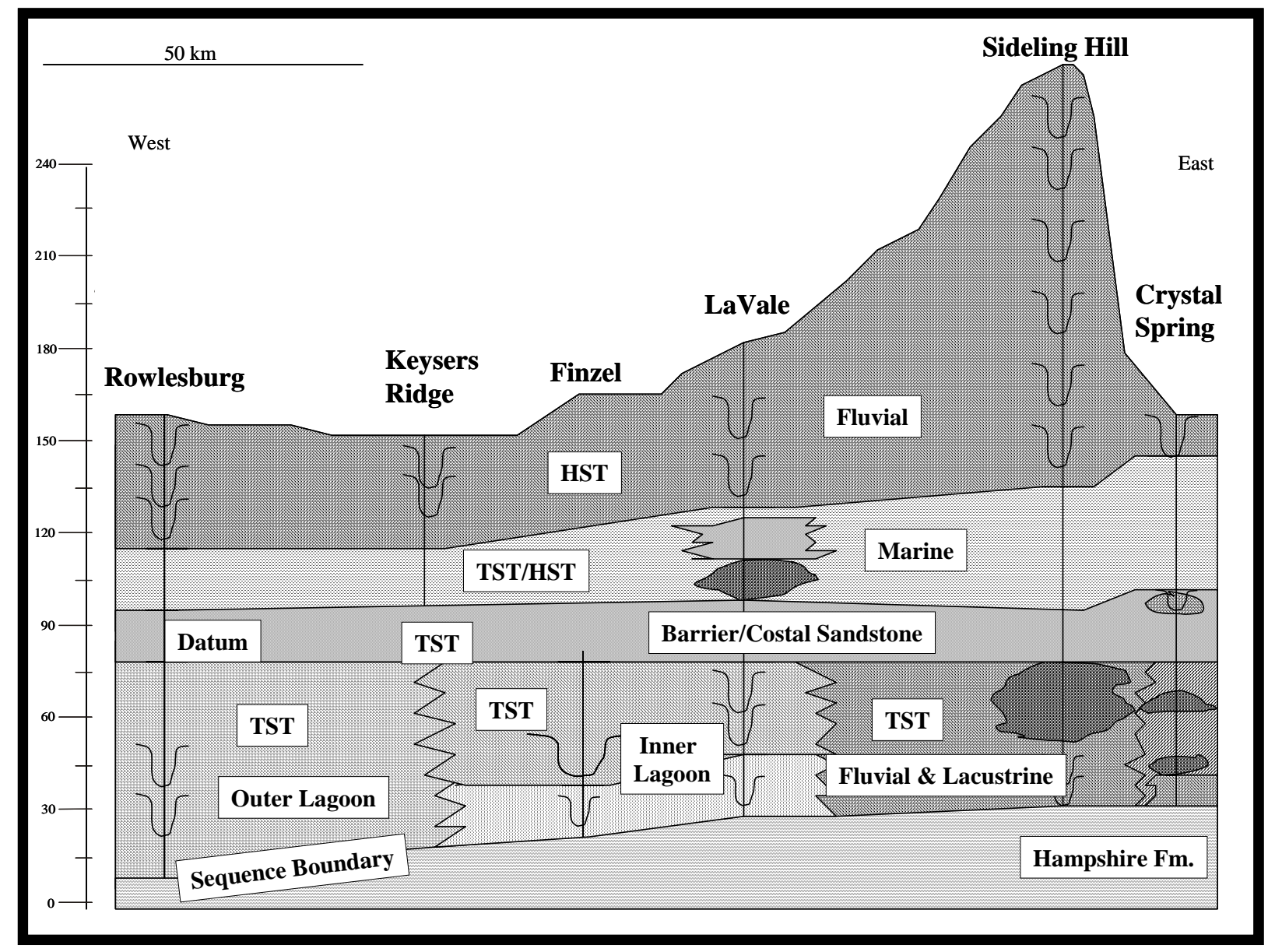

Figure 73. Stick diagram (all columns are to the same scale) showing correlation of all depositional environments and sequence stratigraphic units from west to east. Datum is the base of the barrier/coastal sandstone. Bold spherical pattern represents the diamictite. Horseshoe shaped lines represent channels. 


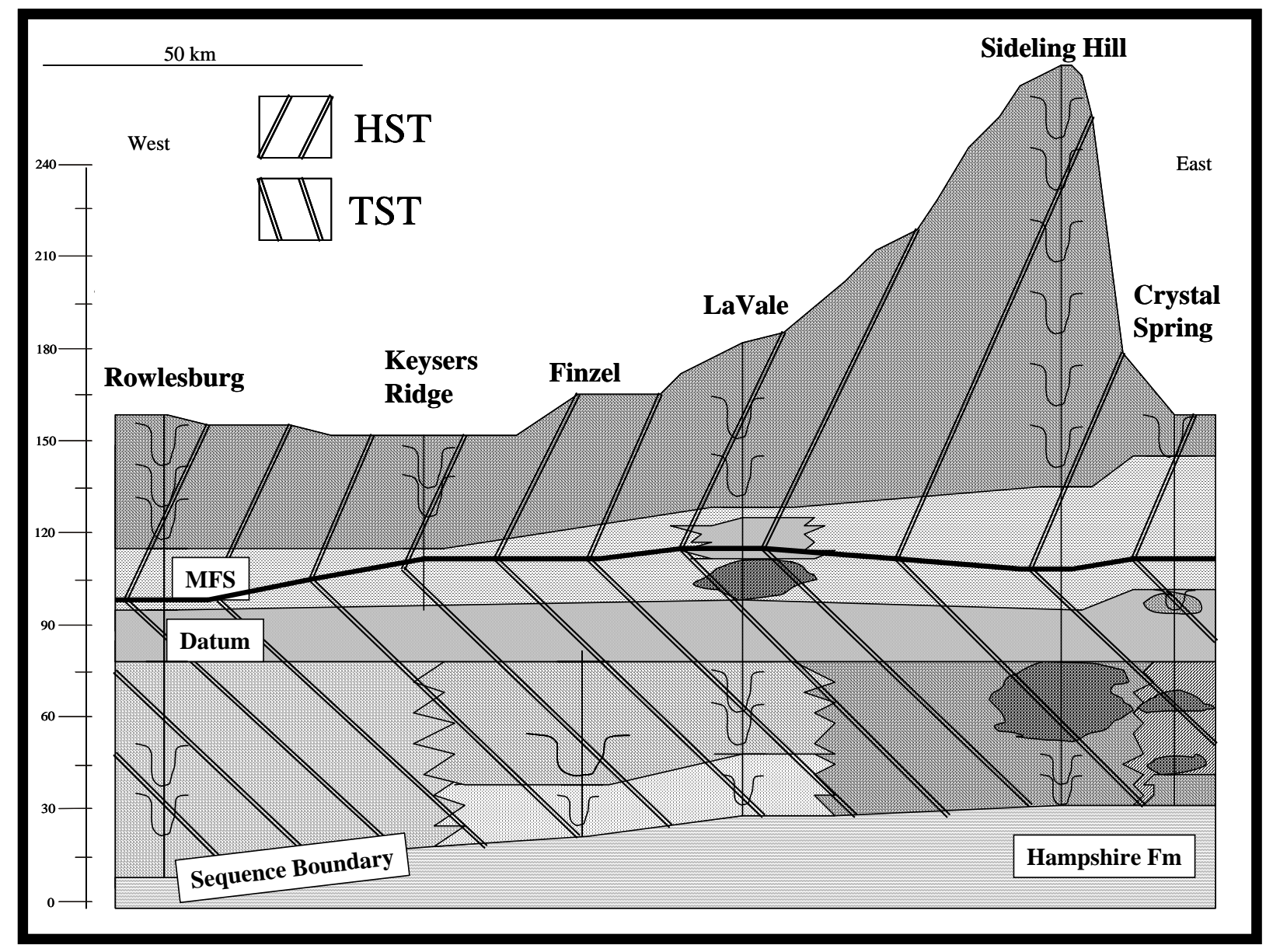

Figure 74. Stick diagram (all columns are to the same scale) showing correlation of the sequence stratigraphic systems tracts from west to east. Datum is the base of the barrier/coastal sandstone. Bold spherical pattern represents the diamictite. Horseshoe shaped lines represent channels. 


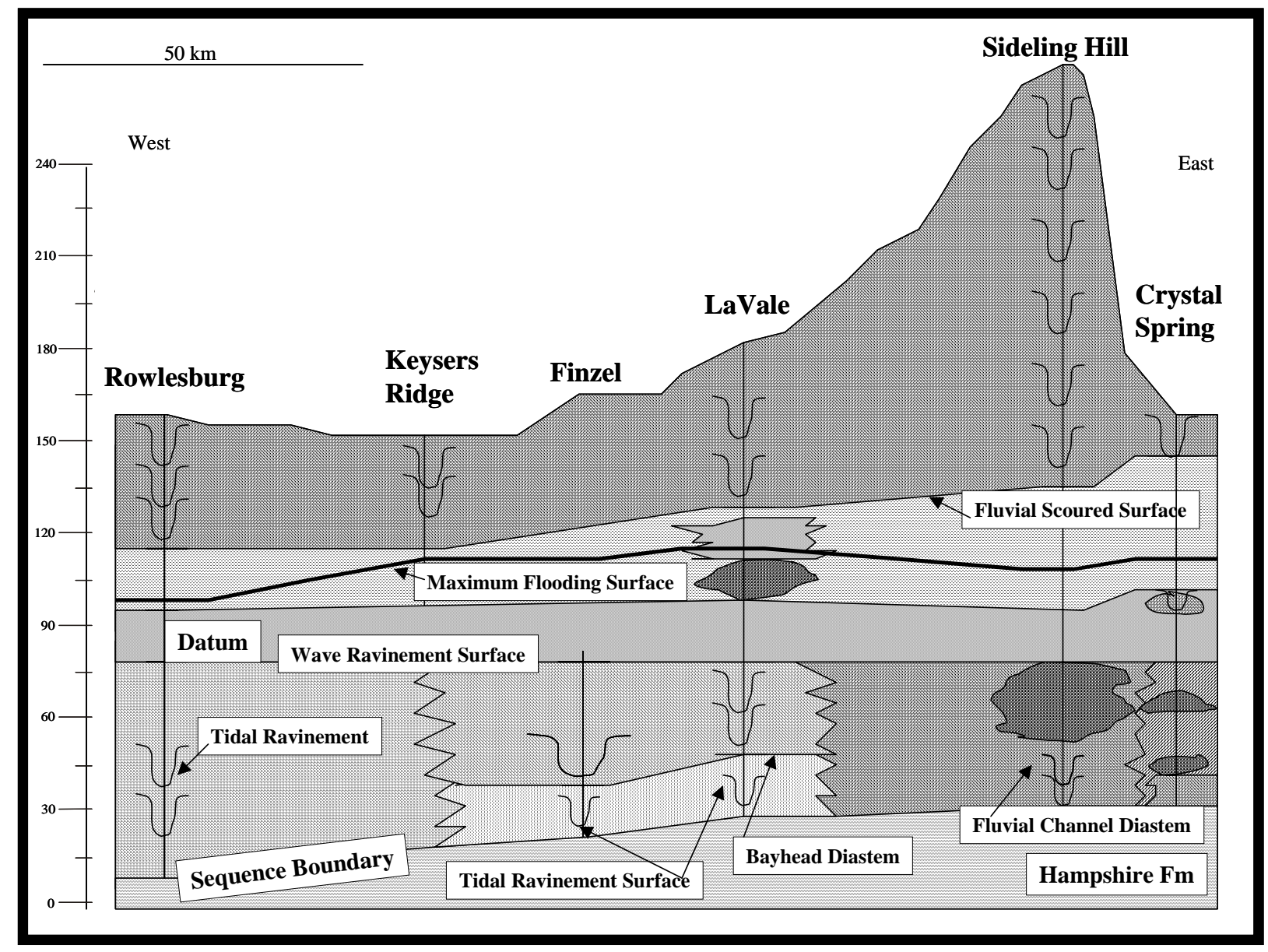

Figure 75. Stick diagram (all columns are to the same scale) showing correlation of the sequence stratigraphic surfaces from west to east. Datum is the base of the barrier/coastal sandstone. Bold spherical pattern represents the diamictite. Horseshoe shaped lines represent channels. 
recognized at the base of the tidal channels were caused by channel migration and scouring of underlying sediments (Fig. 75). Coarse-grained sediments of the bayhead-delta (corresponding to middle estuary of Zaitlin et al.,1994) were derived from an eastern terrestrial source. $48-55 \mathrm{~m}$ of delta-front and delta-plain sediments accumulated as the delta built upward over time. Channel bases within the bayhead-delta mark important erosion surfaces or bayhead diastems (Fig. 75). Fine-grained sediments of the inner lagoon (a sediment sink) were sourced from two directions - barrier island and outer lagoon to the west and bayhead delta and streams to the east. The inner lagoon was generally a low-energy environment; however, it was locally punctuated with tidal channels that exhibit scour surfaces (tidal ravinements). Eventually the fine-grained sediment of the inner lagoon was over-stepped by sediment of the bayhead delta.

Sediments to the east are of fluvial and lacustrine origin (corresponding to the inner estuary of Zaitlin et al., 1994), beyond reach of the transgressing sea. Stacked fluvial deposits at Sideling Hill and stacked lacustrine deposits at Crystal Spring suggest rising sea level had an influence on these coastal-plain sediments. Erosion at the base of sandstone channels is equivalent to local fluvial or channel diastems.

The base of the barrier island sandstone is an erosion surface or wave ravinement. Erosion beneath the barrier sandstone eroded minimal thicknesses of the underlying Oswayo sediments, implying that the marine transgression must have been relatively fast during deposition of the retreating barrier sandstone. The transgression was so extensive that the barrier island migrated landward as far as Sideling Hill and Crystal Spring where it became a coastal beach. At these eastern localities, the base of the coastal-beach sandstone is also a wave ravinement surface. Transgression continued into deposition of the overlying Riddlesburg Shale Member, but that story continues in the thesis of Shane P. Huffman. 


\section{CONCLUSIONS}

The lower Price and equivalent Rockwell Formations of northern West Virginia, eastern Maryland, and south-central Pennsylvania represent rocks that were deposited in a shallow coastal embayment during a relatively slow transgression. The outcrop at Rowlesburg represents the mouth of the embayment with sediment deposited in a marine-influenced outer lagoon. This environment was located behind the barrier islands that closed off the embayment. This facies includes open subtidal, washovers, and tidal channels. Sediments of the marine-influenced outer lagoon aggraded upward and therefore are interpreted to have been deposited during a slow phase of transgression. Thin conglomerates hint of minor sea-level falls.

East of Rowlesburg was the river-influenced inner lagoon with restricted subtidal and bayhead-delta facies. The outcrops at Finzel and LaVale are interpreted to be a part of the shallow embayment that was strongly influenced by fluvial processes and subject to only moderate tidal energy. The lower $20 \mathrm{~m}$ of section in both outcrops comprise thick shale beds with thin sandstones signifying initial deltaic progradation into the shallow, restricted, subtidal lagoon. The overlying bayhead-delta is marked by distributary channels and distributary mouth bars, an aggrading package of sediment that kept pace with rising sea level.

Outcrops at Sideling Hill and Crystal Spring reflect the terrestrial realm of the embayment. Fluvial deposits at Sideling Hill and lake deposits at Crystal Spring overlie the Hampshire red beds. The stacking of thick lake deposits at Crystal Spring signifies a brief fluctuation (rise and fall) in sea-level.

Sandstone of the Cussewago Member represents transgressive beach sediments that changed facies as the beach migrated landward. Near the western mouth of the embayment the sand had more shale breaks, was finer grained, and contained more marine fossils. Once the 
barrier reached the eastern coast, the sands became cleaner, coarser grained with quartz pebbles, and well sorted. The Cussewago is therefore interpreted as a barrier island at Rowlesburg, Finzel, and LaVale, however at Sideling Hill and Crystal Spring it was a coastal beach. Sequence stratigraphy places the Oswayo and Cussewago members of the PriceRockwell Formation into the transgressive systems tract. The base of the Oswayo is a sequence boundary and flooding surface that unconformably overlies Hampshire coastal-plain red beds across the study area. Upon initiation of the latest Devonian transgression, the coast was flooded and a shallow embayment formed. The Oswayo was the first marine sediment to be deposited above the unconformity, making it the base of the transgressive package. The transgressive sandstone above represents the upper half of the package, and the maximum flooding surface lies in the overlying Riddlesburg Shale Member. 


\section{REFERENCES}

Berg, T. M., 1999, Devonian-Mississippian transition, in The Geology of Pennsylvania, ed. by C.H. Shultz, Special Publ. 1, Pennsylvania Geological Survey, p. 128-137.

Berg, T.M., and Edmunds, W.E., 1979, The Huntley Mountain Formation: Catskill-to-Burgoon transition in north-central Pennsylvania: Pennsylvania Geologic Survey, $4^{\text {th }}$ ser., Information Circular 83, 80 p.

Beuthin, J. D., 1986, Facies Interpretation of the Lower Pocono (Devonian-Mississippian) Garrett County, Maryland and Vicinity. (M. S. thesis). Chapel Hill, North Carolina, University of North Carolina, 85 p.

Bjerstedt, T.W., 1986, Regional stratigraphy and sedimentology of the Rockwell Formation and Purslane Sandstone based on the new Sideling Hill road cut, Maryland: Southeast Geology, v. 27, p. 69-94.

Bjerstedt, T.W., 1987. Latest Devonian - Earliest Mississippian nearshore trace - fossil assemblages from West Virginia, Pennsylvania, and Maryland: Journal of Paleontology, v. 61, no. 5, p. 865-889.

Bjerstedt, T.W., and Kammer, T.W., 1988. Genetic stratigraphy and depositional systems of the Upper Devonian - Lower Mississippian Price - Rockwell deltaic complex in the central Appalachians: U.S.A. Sedimentary Geology, v. 54, p. 265-301.

Blum, Michael D., 1993, Genesis and architecture of incised valley fill sequences: a Late Quaternary example from the Colorado River, gulf coastal plain of Texas: Siliciclastic Sequence Stratigraphy, Ch. 10, AAPG, 1994.

Boggs, S., 1995, Principles of sedimentology and stratigraphy: Prentice Hall, Upper Saddle River, NJ, 726 p.

Boswell, R.M., 1985, Stratigraphy and sedimentation of the Upper Devonian-Lower Mississippian Acadian Clastic Wedge in northern West Virginia: Thesis, West Virginia University, Morgantown, West Virginia, 179 p., unpublished.

Brezinski, D.K., 1989. Report of investigation NO. 52 the Mississippian system in Maryland. Department of Natural Resources Maryland Geological Survey.

Carter, J.L., and Kammer, T.W., 1990, Late Devonian and Early Carboniferous brachiopods (brachiopoda, aticulata) from the Price Formation of West Virginia and adjacent areas of Pennsylvania and Maryland: Annals of Carnegie Museum, v. 59, no. 2, p. 77-103.

Castle, J.W., Molz, F. J., Lu, S., Dinwiddie, C. L., 2004, Sedimentology and fractual-based analysis of permeability data, John Henry Member, Straight Cliffs Formation (Upper Cretaceous), Utah, USA: Journal of Sedimentary Research, Vol. 74, No. 2, p. 270 - 284. 
Cecil, C.B., Skema, V., Stamm, R., and Dulong, F.T., 2002, Evidence for Late Devonian and Early Carboniferous global cooling in the Appalachian basin [abs.]: Geological Society of America Abstracts with Programs, v. 34, no. 7, p. 500.

Cherns, L. 1979, The environmental significance of Lingula in the Ludlow Series of the Welsh Borderland and Wales. Lethaia, v. 12, p. 35-46.

Clifton, H.E., 1982, Estuarine deposits; in, Scholle, P.A., and Spearing, D. (ed.), Sandstone Depositional Environments: American Association of Petroleum Geologists, Memoir 31, p. 179189.

Cotter, E., Driese, S.G., 1998, Incised-valley fills and other evidence of sea-level fluctuations affecting deposition of the Catskill Formation (Upper Devonian), Appalachian foreland basin, Pennsylvania: Journal of Sedimentary Research, Vol. 68, No. 2, p. 347 - 361.

Dalyrymple, R.W., Zaitlin, B. A., Boyd, R., 1992, Estuarine facies models: Conceptual basis and stratigraphic implications: Journal of Sedimentary Petrology, Vol. 62, No. 6, p. 1130 - 1146.

Demarest, J.M., \& Kraft, J.C., 1987, Stratigraphic record of Quaternary sea levels: implications for more ancient strata, in Dalrymple, R. W., Zaitlin, B. A., eds., Transgressive facies and sequence architecture in mixed tide- and wave-dominated incised valleys: example from the Gironde Estuary, France: Tulsa, Society of Sedimentary Geology Special Publication 51, p. 225239.

Dennison, J.M., 1985, Catskill Delta shallow marine strata, in Woodrow, D.L., and Sevon, W. D., eds., The Catskill Delta: Geological Society of America special publication 201, p. 91 - 106.

Dennison, J.M., Beuthin, J.D., and Hasson, K.O., 1986, Latest Devonian-earliest Mississippian marine transgressions central and southern Appalachians, U.S.A.: Annuals of Geological Society of Belgium, v. 109, p. 123-129

Gardner, Michael H, 2001, Sequence stratigraphy and facies architecture of fluvial-deltaic reservoir analogs: a field guide to selected outcrops of the Upper Cretaceous Ferron Sandstone Member, central Utah: AAPG fieldtrip guide.

Hettinger, Robert D, et al., 1993, Detailed facies anatomy of transgressive and highstand systems tracts from the Upper Cretaceous of southern Utah, U.S.A.: Siliciclastic Sequence Stratigraphy, Ch. 9, AAPG, 1994.

Kammer, T.W., and Bjerstedt T.W., 1986, Stratigraphic framework of the Price Formation (Upper Devonian - Lower Mississippian) in West Virginia: South Eastern Geology, vol. 27, no. 1, p. 13-32.

McCubbin, D.G., 1981, Barrier island and strand plain facies. In Scholle, P.A., and Spearing, D.R. (Eds.), Sandstone Depositional Environments. Am. Assoc. Petrol. Geol. Mem., 31:247-280. 
Mitchum, Robert M Jr., Van Wagoner, John C, 1991, High - frequency sequences and their stacking patterns: sequence - stratigraphic evidence of high - frequency eustatic cycles: Sedimentary Geology, v. 70, p. 131-160.

Muntingh, A, Brown, L.F. Jr., 1993, Sequence stratigraphy of petroleum plays, post-rift Cretaceous rocks (Lower Aptian to Upper Maastrichtian), Orange basin, western offshore, South Africa: Siliciclastic Sequence Stratigraphy, Ch. 4, AAPG, 1994.

Nichol, S.L., Zaitlin, B.A., Thom, B. G., 1997, The upper Hawkesbury River, New South Wales, Australia: a Holocene example of an estuarine bayhead delta: Sedimentology Vol. 44, p. 263 286.

Nummedal, Dag, Swift, Donald J.P., 1987, Transgressive stratigraphy at sequence-bounding unconformities: some principles derived fro Holocene and cretaceous examples: The Society of Economic Paleontologists and Mineralogists, ...

Posamentier, Henry W, et al., 1992, High resolution sequence stratigraphy-the East Coulee delta, Alberta: Journal of Sedimentary Petrology, v. 62, p. 310-317.

Posamentier, Henry W, et al., 1992, Forced regressions in a sequence stratigraphic framework: concepts, example and exploration significance: The American Association of Petroleum Geologists Bulletin, v. 76, p. 1687-1709.

Reading, H.G., 1996, Sedimentary Environments: Processes, Facies and Stratigraphy. $3^{\text {rd }}$ edition. pp 154-231.

Reger, D. B., 1927, Pocono Stratigraphy in the Broadtop Basin of Pennsylvania: Bulletin of the Geological Society of America, v. 38, p. 397-410.

Sevon, W.D., 1969, The Pocono Formation in northwestern Pennsylvania: Guidebook, $34^{\text {th }}$ Annual Field Conference of Pennsylvania Geologists, Pennsylvania Geological Survey, 129p.

Sevon, W.D., 1979, Polymictic diamictites in the Spechty Kopf and Rockwell Formations, in Dennison, J.M., and others, eds., Devonian shales in south-central Pennsylvania and Maryland: Guidebook, $44^{\text {th }}$ Annual Field Conference of Pennsylvania Geologists, Pennsylvania Geological Survey, p. 61-66; 107-110.

Sevon, W.D., 1985, Nonmarine facies of the Middle and Late Devonian Catskill coastal alluvial plain, in Woodrow, D.L., and Sevon, W.D., The Catskill Delta: Geological Society of America Special Paper 201, p. 79-90.

Shanmugam, G., Poffenberger, M., Alava, J.T., 2000, Tide-dominated estuarine facies in the Hollin and Napo ("T" and "U”) Formations (Cretaceous), Sacha Field, Oriente Basin, Ecuador: AAPG Bulletin, Vol. 84, No. 5, p. 652 - 682. 
Sloss, L.L., 1963, Sequences in the cratonic interior of north America: Geological Society of America Bulletin, v. 74, p. 93-114.

Suter, T.D., 1991, The origin and significance of Mississippian polymictic diamictites in the Central Appalachian Basin. (Docterate). Morgantown, West Virginia, West Virginia University, $370 \mathrm{p}$.

Swift, D.J.P., 1968, Coastal erosion and transgressive stratigraphy: Journal of Geology, v. 76, p. 44-456.

Tye, Robert S, 1993, Integrated stratigraphic and depositional-facies analysis of parasequences in a transgressive systems tract, San Joaquin basin, California: Siliciclastic Sequence Stratigraphy, Ch. 5, AAPG, 1994.

Woodrow, D.L., 1985. Paleography, paleoclimate, and sedimentary processes of the Late Devonian Catskill Delta, in The Catskill Delta: Geological Society of America, Sp. Paper 201 pp. 51-63.

Vail, P.R., R.M. Mitchum, and S. Thompson, 1977, Seismic stratigraphy and global changes of sea level, part 3: Relative changes of sea level from coastal onlap, in C.E. Clayton, ed., Seismic stratigraphy - applications to hydrocarbon exploration: Tulsa, Oklahoma, American Association of Petroleum Geologists Memoir 26, p. 63-81.

Van Heerden, I.L., \& Roberts, H. H., 1988, Facies development of Atchafalaya Delta, Louisiana: a modern bayhead delta: AAPG Bulletin Vol. 72, No. 4, p. 439 - 453.

Van Wagoner, J.C., Mitchum, R.M., Jr., Campion, K.M. \& Rahmanian, V.D., 1990, Siliciclastic Sequence Stratigraphy in Well Logs, Cores and Outcrop: Concepts for High Resolution Correlation of Time and Facies. American Association of Petroleum Geologists Methods in Exploration Series, Tulsa, 7, 55 pp.

Weimer, Robert J., 1992, Developments in sequence stratigraphy: Foreland and cratonic basins, The AAPG Bulletin v. 76, no. 7, p. 965-982.

Wright, V. Paul, Marriot, Susan B, 1993, The sequence stratigraphy of fluvial depositional systems: the role of floodplain sediment storage: Sedimentary Geology, v. 86, p. 203-210.

Zaitlin, B.A., Dalrymple, R.W., and Boyd, R., 1994, The stratigraphic organization of incisedvalley systems associated with relative sea-level changes; in, Incised valley systems--Origin and sedimentary sequences, R. Boyd, B. A. Zaitlin, and R. Dalrymple, eds.: Society of Economic Paleontologists and Mineralogists, Special Publication 51, p. 45-60. 


\section{APPENDIX I}

\section{FIELD NOTES AND STRATIGRAPHIC COLUMNS}




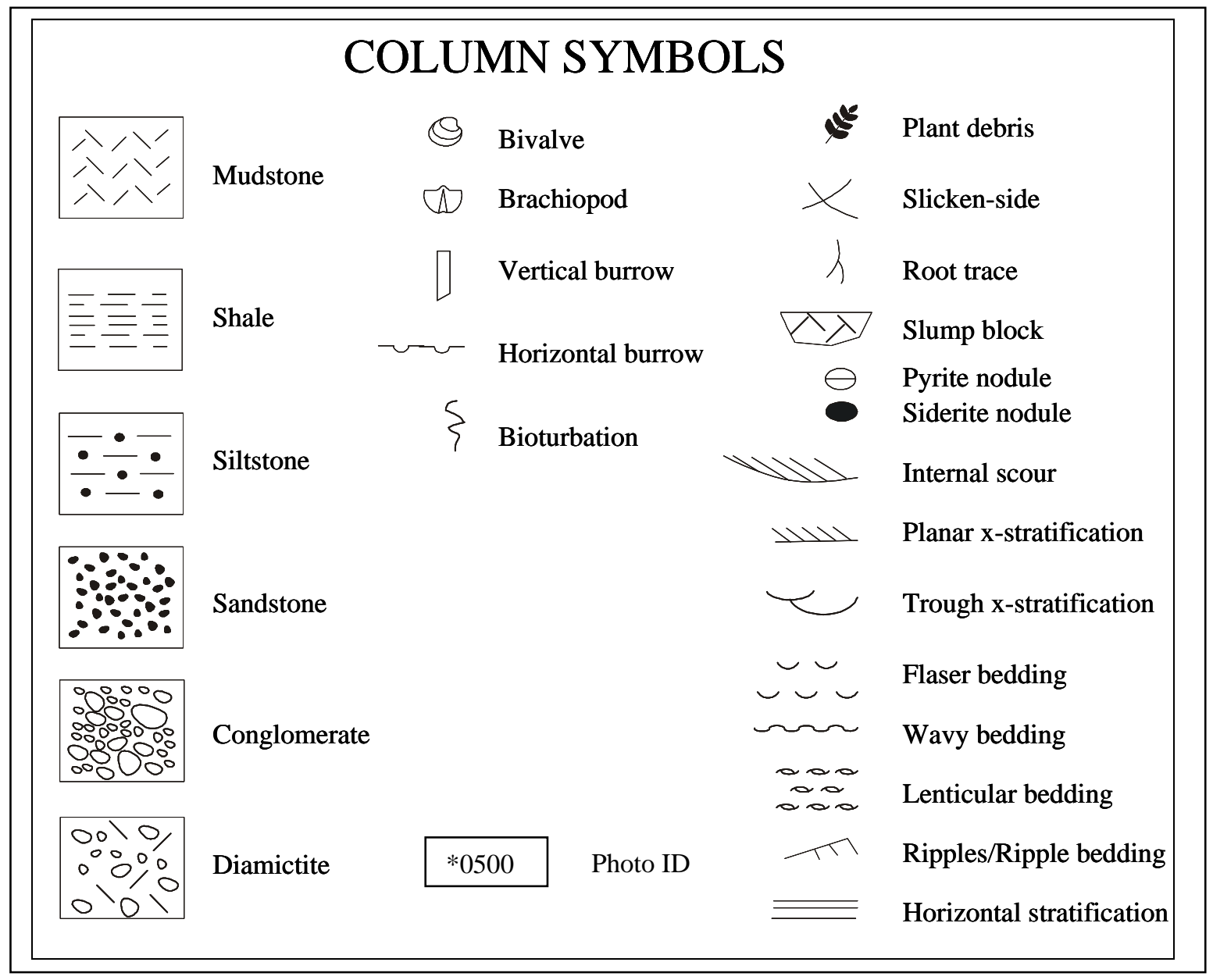




\section{ROWLESBURG WEST VIRGINIA OUTCROP}


Rowlesburg Outcrop

Location: $2.5 \mathrm{~km}$ northwest of Rowlesburg, WV, in Preston County along the Baltimore and Ohio Railroad

Date: March - April, 2003

UNIT 1: Thickness $-0.30 \mathrm{~m}(0.98 \mathrm{ft})$

Rock name - SILTSTONE to very fine-grained SANDSTONE

Rock color - Green-gray (fresh) dark gray (weathered)

Bedding - Thinnly bedded (6-8 cm). Above $15 \mathrm{~cm}$ from base unit becomes massive

Sed. Structures - Basal $15 \mathrm{~cm}$ contains small-scale laminations. Above, laminations disappear

and grain size changes to a very fine-grain sandstone.

Trace \& body fossils - No trace or body fossils observed.

Comments - Sharp basal contact

UNIT 2: Thickness - $3.2 \mathrm{~m}(10.5 \mathrm{ft})$

Rock name - Interbedded SILTSTONE and SHALE with one thin $(19-15 \mathrm{~cm})$ thick fine-grained SANDSTONE

Rock color - Green-gray (fresh), orange-brown (weathered)

Bedding - Thin to medium bedded siltstone and shale. Sandstone unit is lenticular. Shale is

fissile.

Sed. Structures - No sedimentary structures observed

Trace \& body fossils - No trace or body fossils observed

Comments - Unit mostly covered except for upper $50 \mathrm{~cm}$. Sandstone unit is $20 \mathrm{~cm}$ from the top of the unit. Sharp basal contact.

UNIT 3: Thickness - $1.4 \mathrm{~m}(4.6 \mathrm{ft})$

Rock name - Medium to very fine-grained SANDSTONE

Rock color - Green-gray (fresh), gray to orange-brown (weathered)

Bedding - Very thick to thickly bedded. Basal sandstone is $44 \mathrm{~cm}$ with a $6 \mathrm{~cm}$ shale parting at top. Next sandstone is $55 \mathrm{~cm}$ thick. Rest of unit characterized by 3 distinct shale partings about $3 \mathrm{~cm}$ thick. $10-15 \mathrm{~cm}$ from top is a $5 \mathrm{~cm}$ thick sandstone (contains horizontal stratification).

Sed. Structures - Horizontal stratification in sandstone bed 10-15 cm from top of unit. Rest of unit lacks sedimentary structures.

Trace \& body fossils - Apparent trace fossils at base of unit

Comments - Sharp basal contact

UNIT 4: Thickness $-0.4 \mathrm{~m}(1.3 \mathrm{ft})$

Rock name - Interbedded fine-grained SANDSTONE and SILTY SHALE

Rock color - Green-gray (fresh), buff-tan (weathered)

Bedding - Very thin to thinly bedded, no significant trend in bedding

Sed. Structures - No sedimentary structures observed

Trace $\&$ body fossils - Trace or body fossils observed

Comments - Gradational basal contact

UNIT 5: Thickness $2.9 \mathrm{~m}(9.5 \mathrm{ft})$

Rock name - Very fine-grained SANDSTONE (basal $90 \mathrm{~cm}$ ) to SILTSTONE 
Rock color - Gray (fresh), buff-yellow (weathered)

Bedding - Thickly bedded. Upper $1.1 \mathrm{~m}$ is inaccessible but appears medium bedded. Assuming to be siltstone.

Sed. Structures - Horizontal stratification in the thickly bedded lower portion of unit

Trace \& body fossils - Plant debris within middle $90 \mathrm{~cm}$ of unit. No trace or body fossils observed

Comments - Gradational basal contact

UNIT 6: Thickness - $1.5 \mathrm{~m}$ (4.9 ft)

Rock name - SHALE

Rock color - Green-gray

Bedding - No bedding observed

Sed. Structures - No sedimentary structures observed

Trace \& body fossils - No trace or body fossils observed

Comments - Unit is mostly covered and the base is concealed

UNIT 7: Thickness $-0.60 \mathrm{~m}$ (2.0 ft)

Rock name - Very fine-grained SANDSTONE

Rock color - Dark gray (fresh), tan (weathered)

Bedding - Bedding is massive

Sed. Structures - No sedimentary structures observed

Trace $\&$ body fossils - No trace or body fossils observed

Comments - Gradational basal contact

UNIT 8: Thickness - $2.4 \mathrm{~m}$ (7.9 ft)

Rock name - SHALE with interbedded SILTSTONE

Rock color - Dark gray (fresh), light gray (weathered)

Bedding - Siltstone beds are more abundant at base of unit but pinch and swell. Upper half becomes much more shaly. Shale is fissile.

Sed. Structures - No sedimentary structures observed

Trace \& body fossils - Scattered bivalves (brachiopods?) in upper $30 \mathrm{~cm}$

Comments - Sharp basal contact

UNIT 9: Thickness - $1.2 \mathrm{~m}$ (3.9 ft)

Rock name - Interbedded SILTSTONE and SHALE

Rock color - Light gray (fresh), tan-buff (weathered)

Bedding - Basal $30 \mathrm{~cm}$ is fissile shale. Rest of unit contains alternating lenses of shale and siltstone (six lenses of siltstone, very thinly bedded).

Sed. Structures - No sedimentary structures observed

Trace \& body fossils - Trace fossils observed were horizontal and vertical. Unit appears bioturbated and contains scattered brachiopods.

Comments - Unit is a distinct ledge former and has a sharp basal contact

UNIT 10: Thickness - $0.60 \mathrm{~m}(2.0 \mathrm{ft})$

Rock name - SHALE and very fine-grained SANDSTONE (upper $30 \mathrm{~cm}$ )

Rock color - Dark gray shale near the base but the top changes to a light gray sandstone 
Bedding - Shale is fissile but not bedded. Unit is thickest near the base

Sed. Structures - Shale is laminated. No sedimentary structures observed in the sandstone.

Trace \& body fossils - No trace or body fossils observed

Comments - Unit thickness changes due to sharp down-cutting by overlying sandstone. Within

20 yards of horizontal distance, UNIT 10 is down-cut about 1.0 meter. Upper $30 \mathrm{~cm}$ has very

fine-grain sandstone lenses, 3-5 cm thick. Sandstone lenses contain mica layers.

UNIT 11: Thickness - $4.3 \mathrm{~m}(14.1 \mathrm{ft})$

Rock name - Fine to slightly finer-grained SANDSTONE

Rock color - Gray (fresh), tan-buff (weathered)

Bedding - Medium to thickly bedded. Unit contains well defined master bedding planes

(reactivation surface).

Sed. Structures - Lower $30 \mathrm{~cm}$ contains horizontal stratification. Next $30 \mathrm{~cm}$ contains very distinct trough cross-stratification. Rest of unit grades between trough-cross and planar cross stratification. Troughs are well defined but in isolated areas, no more than $20 \mathrm{~cm}$ thick. The top is dominated by planar stratification.

Trace \& body fossils - Unit contains distinct horizontal burrows (Cruziana) and concave down brachiopods only along the basal scoured surface. First 3-4 cm of base is bioturbated. Scattered plant material along basal bedding plane.

Comments - Sharp basal contact

UNIT 12: Thickness - $2.4 \mathrm{~m}$ (7.9 ft)

Rock name - Very fine-grained SANDSTONE, SILTSTONE, and SHALE

Rock color - Dark gray (fresh)

Bedding - Bedding is thin at base

Sed. Structures - Sandstone is moderately ripple bedded, loose bedding upward. No sedimentary structures observed in siltstone. Shale is somewhat fissile and laminated.

Trace $\&$ body fossils -Distinct vertical burrows in shale.

Comments - Plant debris scattered throughout siltstone layer. Sharp basal contact.

UNIT 13: Thickness $-0.60 \mathrm{~m}(2.0 \mathrm{ft})$

Rock name - Very fine-grained SANDSTONE

Rock color - Gray to medium gray (fresh)

Bedding - Medium bedded to very thin toward top

Sed. Structures - No sedimentary structures observed

Trace \& body fossils - Large horizontal burrows scattered throughout but appear to be more abundant along the basal bedding surface. No body fossils observed.

Comments - Sharp basal contact and unit defines a distinct ledge

UNIT 14: Thickness - $1.3 \mathrm{~m}$ (4.3 ft)

Rock name - SHALE and MUDSTONE

Rock color - Dark gray

Bedding - Unit mostly covered

Sed. Structures - No sedimentary structures observed

Trace \& body fossils - No trace or body fossils observed

Comments - Sharp basal contact based on break in slope 
UNIT 15: Thickness $-0.7 \mathrm{~m}(2.3 \mathrm{ft})$

Rock name - Very fine-grained SANDSTONE

Rock color - Gray to dark gray (fresh), rusty brown (weathered)

Bedding - No distinct bedding, somewhat disturbed

Sed. Structures - No sedimentary structures observed

Trace \& body fossils - No trace or body fossils observed but unit appears bioturbated

Comments - Sharp basal contact

UNIT 16: Thickness - $0.7 \mathrm{~m}(2.3 \mathrm{ft})$

Rock name - SHALE and MUDSTONE

Rock color - Dark gray (fresh), rusty brown (weathered)

Bedding - Fissile in places to platy

Sed. Structures - No sedimentary structures observed

Trace \& body fossils - No trace or body fossils observed

Comments - Gradational basal contact

UNIT 17: Thickness - $1.1 \mathrm{~m}$ (3.6 ft)

Rock name - Very fine-grained SANDSTONE

Rock color - Dark gray

Bedding - Bedding is thick. Unit contains a $1 \mathrm{~cm}$ thick shale parting in the center

Sed. Structures - No sedimentary structures observed

Trace \& body fossils - Possible horizontal burrows along a basal bedding plane midway up the unit, forming a distinct ledge.

Comments - Sharp basal contact

UNIT 18: Thickness $-0.9 \mathrm{~m}(2.9 \mathrm{ft})$

Rock name - SHALE

Rock color - Dark gray

Bedding - Fissile but not laminated

Sed. Structures - No sedimentary structures observed

Trace \& body fossils - No trace or body fossils observed

Comments - Gradational basal contact

UNIT 19: Thickness $-0.20 \mathrm{~m}(0.7 \mathrm{ft})$

Rock name - LIMESTONE/MICRITE?

Rock color - Dark gray

Bedding - Not available

Sed. Structures - No sedimentary structures observed

Trace \& body fossils - No trace or body fossils observed

Comments - Sharp basal contact, unit has lateral continuity

UNIT 20: Thickness $-0.10 \mathrm{~m}(0.3 \mathrm{ft})$

Rock name - SHALE

Rock color - Dark gray

Bedding - Fissile but not laminated 
Sed. Structures - No sedimentary structures observed

Trace \& body fossils - No trace or body fossils observed

Comments - Sharp basal contact

UNIT 21: Thickness - $1.4 \mathrm{~m}$ (4.6 ft)

Rock name - Very fine to fine-grained SANDSTONE

Rock color - Dark gray to gray (fresh), rusty brown (weathered)

Bedding - Massive

Sed. Structures - No sedimentary structures observed

Trace \& body fossils - Possible bioturbation in upper $20 \mathrm{~cm}$

Comments - Sharp basal contact

UNIT 22: Thickness $-0.40 \mathrm{~m}$ (1.3ft)

Rock name - Fine-grained SANDSTONE

Rock color - Dark gray

Bedding - Thinnly bedded

Sed. Structures - Ripple bedded throughout

Trace \& body fossils - Horizontal burrows on basal bedding plane and possible brachiopods

Comments - Gradational basal contact

UNIT 23: Thickness - $2.8 \mathrm{~m}(9.2 \mathrm{ft})$ Unit inaccessible

Rock name - Interbedded fine-grained SANDSTONE and SHALE

Rock color - Gray

Bedding - Sandstone beds thicken up. Two distinct beds at very top with a shale break between.

Lower half is interbedded thin sandstone and shale beds

Sed. Structures - Unit is inaccessible

Trace \& body fossils - Unit is inaccessible

Comments - Gradational basal contact

UNIT 24: Thickness - $5.6 \mathrm{~m}$ (18.4ft)

Rock name - Medium to fine-grained SANDSTONE

Rock color - Gray

Bedding - Very thick to thickly bedded at top

Sed. Structures - Trough cross-bedded at base to horizontal stratification in middle and trough

cross-bedded at top. Upper most beds appear massive.

Trace \& body fossils - No trace or body fossils observed

Comments - Sharp basal erosional contact. Unit scours 3.4 m down into UNIT 21.

UNIT 25: Thickness - $1.9 \mathrm{~m}(6.2 \mathrm{ft})$

Rock name - Very fine to fine-grained SANDSTONE

Rock color - Green gray

Bedding - Thinnly bedded. Unit contains recessed beds but no apparent shale breaks.

Sed. Structures - Low-angle planar cross-stratification near the base

Trace $\&$ body fossils - Top of unit is bioturbated with vertical burrows. No body fossils observed.

Comments - Gradational basal contact 
UNIT 26: Thickness - $0.4 \mathrm{~m}$ (1.3 ft)

Rock name - Fine-grained SANDSTONE

Rock color - Dark gray

Bedding - Massive

Sed. Structures - No sedimentary structures observed

Trace \& body fossils - No trace or body fossils observed

Comments - Sharp basal contact

UNIT 27: Thickness - $3.0 \mathrm{~m}(9.8 \mathrm{ft})$

Rock name - Fine-grained SANDSTONE and SHALE

Rock color - Sandstone is gray, shale is very dark gray. Shale weathers a reddish color.

Bedding - Lower $2.0 \mathrm{~m}$ is thickly bedded sandstone and rest of unit is shale

Sed. Structures - No sedimentary structures observed

Trace \& body fossils - No trace or body fossils observed

Comments - Gradational basal contact, unit mostly covered and poorly exposed

UNIT 28: Thickness - $1.8 \mathrm{~m}(5.9 \mathrm{ft})$

Rock name - Fine-grained SANDSTONE and SHALE

Rock color - Sandstone is green-gray, shale is gray

Bedding - Sandstone is medium to thickly bedded. Top $10-20 \mathrm{~cm}$ is shale

Sed. Structures - No sedimentary structures observed

Trace \& body fossils - No trace or body fossils observed

Comments - Sharp basal contact, unit mostly covered and poorly exposed

UNIT 29: Thickness - 1.8 m (5.9 ft) Unit inaccessible

Rock name - Fine-grained SANDSTONE

Rock color - Green-gray

Bedding - Sandstone is medium to thickly bedded

Sed. Structures - Unit is inaccessible

Trace \& body fossils - Unit is inaccessible

Comments - Sharp basal contact

UNIT 30: Thickness - $5.3 \mathrm{~m}$ (17.4 ft)

Rock name - Fine-grained SANDSTONE

Rock color - Light gray to green gray (fresh), gray (weathered)

Bedding - Thickly bedded to very thick

Sed. Structures - Horizontal stratification

Trace \& body fossils - Base of bedding planes appear bioturbated. Horizontal burrows and vertical burrows evident on underside of bedding planes. No apparent body fossils.

Comments - Slightly covered sharp basal contact. $1.1 \mathrm{~m}$ of upper section becomes more massive, turns green-gray, and no bioturbation.

UNIT 31: Thickness - $2.5 \mathrm{~m}(8.2 \mathrm{ft})$

$\underline{\text { Basal } 1.2 \mathrm{~m}}$

Rock name - Very fine-grained SANDSTONE 
Rock color - Dark green-gray (fresh), gray (weathered)

Bedding - Medium

Sed. Structures - No sedimentary structures observed

Trace \& body fossils - Moderately bioturbated. Skolithos throughout. No apparent body fossils

Comments - Gradational basal contact

Middle Lower $0.3 \mathrm{~m}$

Rock name - SHALE

Rock color - Dark gray

Bedding - Fissile

Sed. Structures - No sedimentary structures observed

Trace \& body fossils - No trace or body fossils observed

Comments - Base is marked by a $1 \mathrm{~cm}$ thick underclay, mottled and light gray

Middle Upper $0.4 \mathrm{~m}$

Rock name - Very fine-grained SANDSTONE

Rock color - Dark green-gray

Bedding - Thickly bedded

Sed. Structures - Top appears horizontally stratified but disturbed by bioturbation

Trace \& body fossils - Bioturbated but no apparent body or trace fossils

Comments - Sharp basal contact

Upper $0.6 \mathrm{~m}$

Rock name - SHALE with interbedded SILTSTONE

Rock color - Shale is dark gray, siltstone is gray

Bedding - Shale is fissile. Siltstone lenses are very thin to thinly bedded

Sed. Structures - No sedimentary structures observed

Trace \& body fossils - Vertical burrows in middle shale horizon. No apparent body fossils.

Comments - Sharp basal contact

UNIT 32: Thickness - $3.1 \mathrm{~m}$ (10.2 ft)

Rock name - Very fine- to fine-grained SANDSTONE

Rock color - Dark gray

Bedding - From base, bedding is very thick, medium, thick, and back to medium

Sed. Structures - No sedimentary structures observed

Trace \& body fossils - Abundant vertical burrows along upper bedding planes. Horizontal burrows along basal bedding surfaces. No apparent body fossils.

Comments - Unit is mostly sandstone with minor shale partings at the top. Unit changes

weathering profile from blocky to massive upwards. Unit appears bioturbated. Sharp basal contact.

UNIT 33: Thickness - $1.7 \mathrm{~m}$ (5.6 ft)

Rock name - Very fine-grained SANDSTONE with discontinuous SHALE lenses

Rock color - Gray

Bedding - Lenticular

Sed. Structures - No sedimentary structures observed

Trace \& body fossils - Vertical and horizontal burrows on bedding surfaces

Comments - Sharp basal contact. Above Unit 33 there is a $0.50 \mathrm{~m}$ conglomerate lens that appears to have been a paleo-high. 
UNIT 34: Thickness - $7.6 \mathrm{~m}$ (24.9 ft)

Rock name - Very fine-grained SANDSTONE with quartz-pebble CONGLOMERATE

Rock color - Light gray

Bedding - Medium to thickly bedded and moderately blocky. Some beds are wedge-shaped.

Sed. Structures - Horizontal stratification at base with minor ripples near top. Large- and smallscale planar cross-stratitification near the top.

Trace \& body fossils - Bioturbated at top just below the covered interval. Large horizontal burrow along basal and upper bedding surfaces, possibly Cruziana burrows. Brachiopods were observed.

Comments - Upper 2.9 m covered. Two quartz-pebble conglomerate lenses $30 \mathrm{~cm}$ thick were observed. Sharp basal contact with quartz-pebble conglomerate.

UNIT 35: Thickness - $4.0 \mathrm{~m}(13.1 \mathrm{ft})$

Rock name - SHALE

Rock color - Dark gray (fresh), rusty orange-brown (weathered)

Bedding - Hackly to blocky

Sed. Structures - No sedimentary structures observed

Trace \& body fossils - Some minor burrows, no apparent body fossils

Comments - Micaceous with scattered nodules. Sharp basal contact.

UNIT 36: Thickness - $8.4 \mathrm{~m}(27.6 \mathrm{ft})$

$\underline{\text { Lower }}$

Rock name - Medium-grained SANDSTONE minor shale breaks

Rock color - Light gray

Bedding - Thick to very thick, massive in places

Sed. Structures - Horizontal stratification

Trace \& body fossils - No trace or body fossils observed

Comments - Sharp basal contact

Middle

Rock name - Medium-grained SANDSTONE

Rock color - Light gray

Bedding - Massive

Sed. Structures - Horizontal stratification

Trace \& body fossils - Appears to contain horizontal burrows

Comments - Gradational basal contact

Upper

Rock name - Very fine-grained SANDSTONE with minor shale breaks

Rock color - Light gray

Bedding - Thick to very thick

Sed. Structures - Trough cross-stratification

Trace \& body fossils - No trace or body fossils observed

Comments - Unit contains few minor shale breaks. Gradational basal contact.

UNIT 37: Thickness - $23.5 \mathrm{~m}(77.1 \mathrm{ft})$ 


\section{Lower $9.0 \mathrm{~m}(\mathrm{ft})$}

Rock name - Interbedded very fine-grained SANDSTONE and SHALE

Rock color - Sandstone is gray, shale is dark gray

Bedding - Shale is fissile not laminated. Sandstone is medium bedded near middle and thin to very thinly bedded near the top.

Sed. Structures - Sandstone bed near top contains horizontal stratification. No sedimentary structures observed in shale

Trace \& body fossils - No trace or body fossils observed

Comments - Unit increases in shale content toward top. $17 \mathrm{~m}$ from base of Unit there is a thin conglomerate bed.

Upper $14.5 \mathrm{~m}(\mathrm{ft})$

Rock name - SHALE and interbedded very fine-grained SANDSTONE

Rock color - Sandstone is gray, shale is dark gray

Bedding - Medium bedded with channel body form. Shale is fissile

Sed. Structures - Planar stratification towards the top of the unit

Trace \& body fossils - No trace or body fossils observed

Comments - Conglomerate beds pinch out. Sharp basal contact.

UNIT 38: Thickness - $4.6 \mathrm{~m}$ (15.1 ft)

Rock name - Fine- to very fine-grained SANDSTONE

Rock color - Gray

Bedding - Massive

Sed. Structures - Horizontal stratification in lower and middle portion of unit

Trace \& body fossils - No trace or body fossils observed

Comments - Sharp erosional basal contact, $1.5 \mathrm{~m}$ of scour

UNIT 39: Thickness - $4.6 \mathrm{~m}$ (15.1 ft)

Rock name - SHALE with interbedded very fine-grained SANDSTONE

Rock color - Shale is green-gray to dark gray, sandstone is gray

Bedding - Shale is fissile and laminated

Sed. Structures - No sedimentary structures observed

Trace \& body fossils - No trace or body fossils observed

Comments - Unit is mostly covered. Gradational basal contact

UNIT 40: Thickness - $38.1 \mathrm{~m}$ (125 ft)

Rock name - Fine- to medium-grained SANDSTONE

Rock color - Green-gray at base to red-gray at top

Bedding - Overall bedding is massive with channel body form but changes to medium at $10.6 \mathrm{~m}$

Sed. Structures - Sandstone at base has horizontal stratification. Planar cross- stratification was

observed near the middle to upper portion of the unit.

Trace \& body fossils - No trace or body fossils observed

Comments - Unit overall appears to be stacked channel-form sandstones. Near $10.6 \mathrm{~m}$ from base unit changes back to massive and gradually to very massive. Grain size increases slightly. At approximately $24.6 \mathrm{~m}$ unit becomes interbedded with shale (upper $14 \mathrm{~m}$ ). Sharp erosional basal contact. 


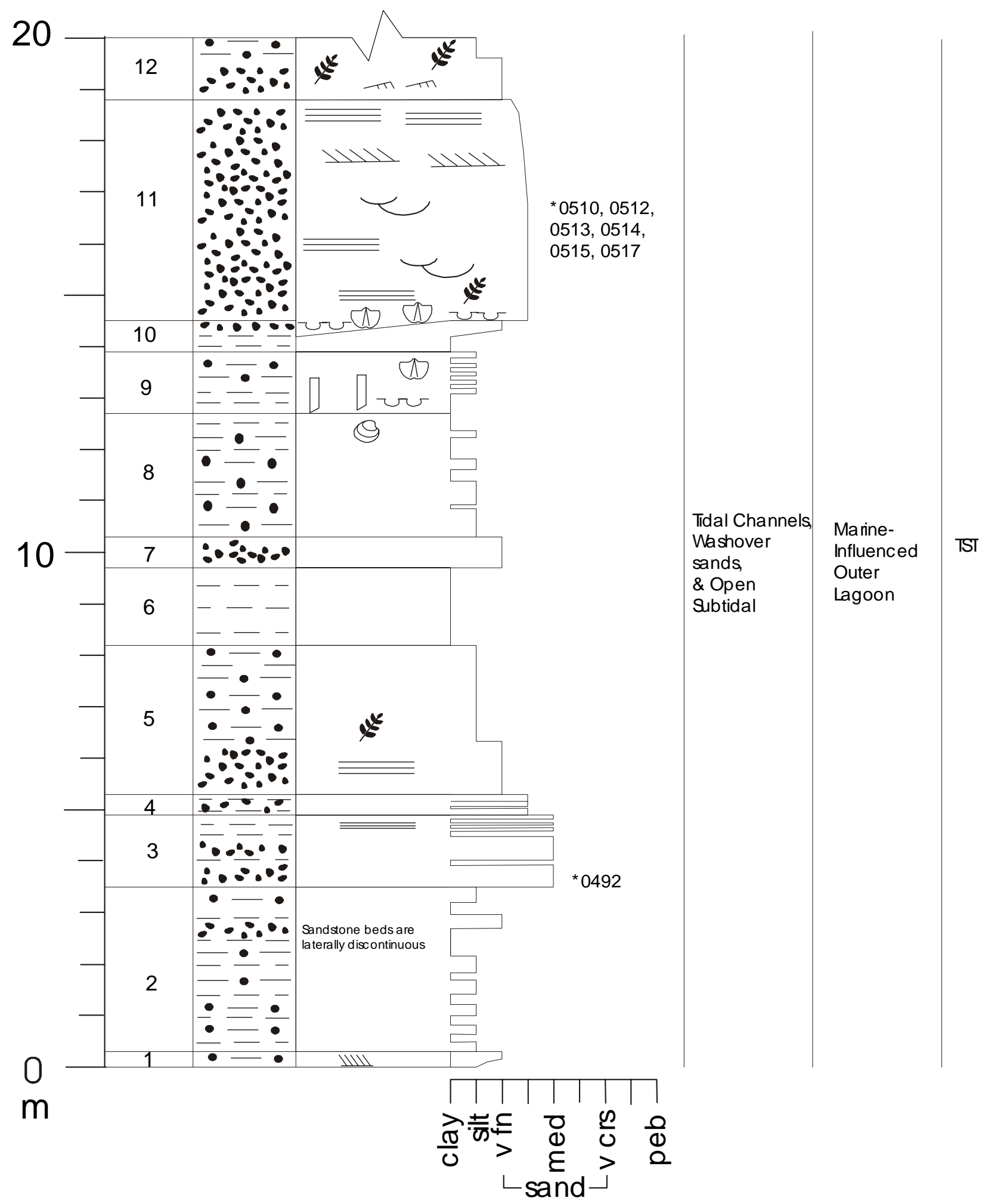

Rowlesburg, WV 


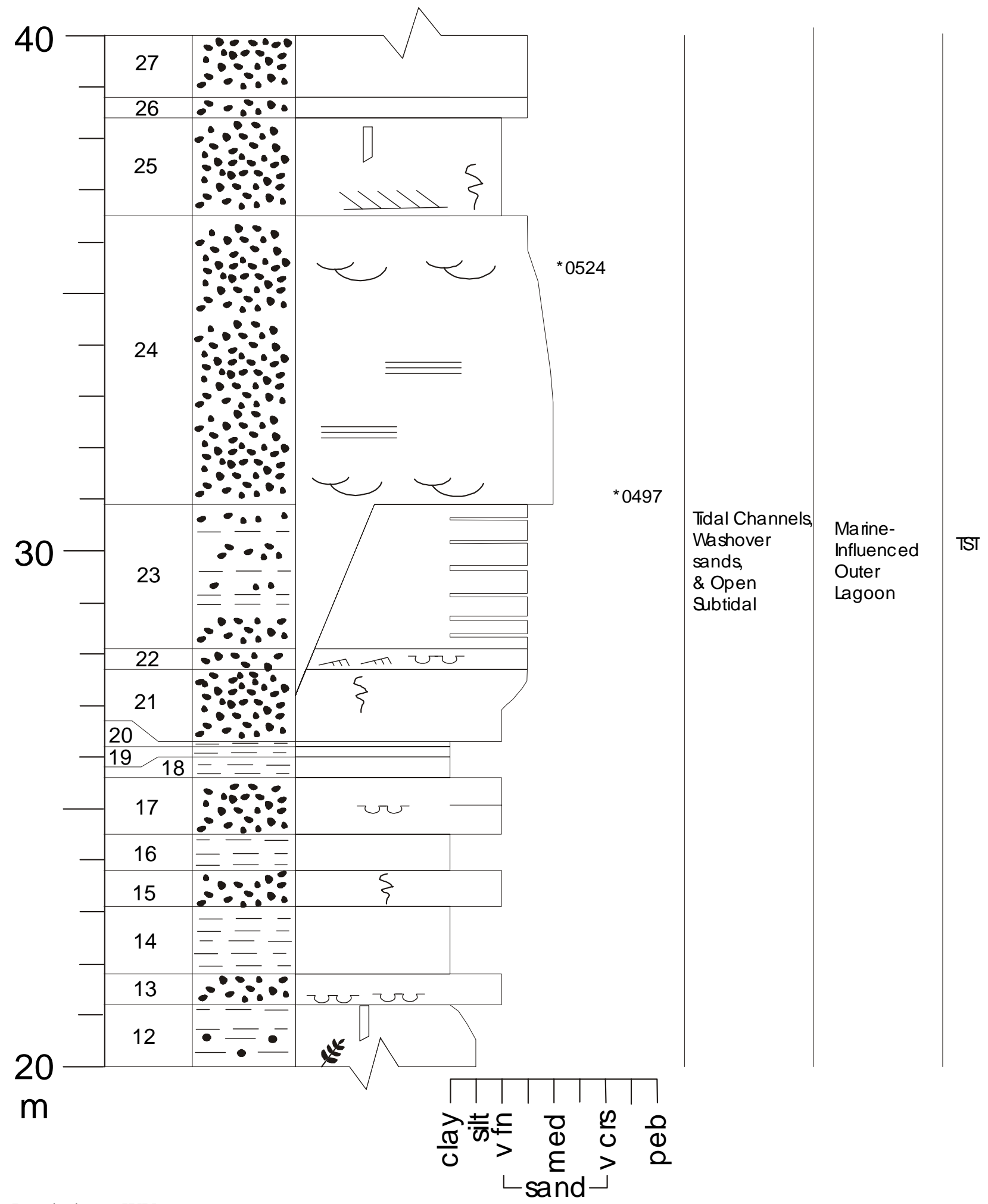

Rowlesburg, WV 


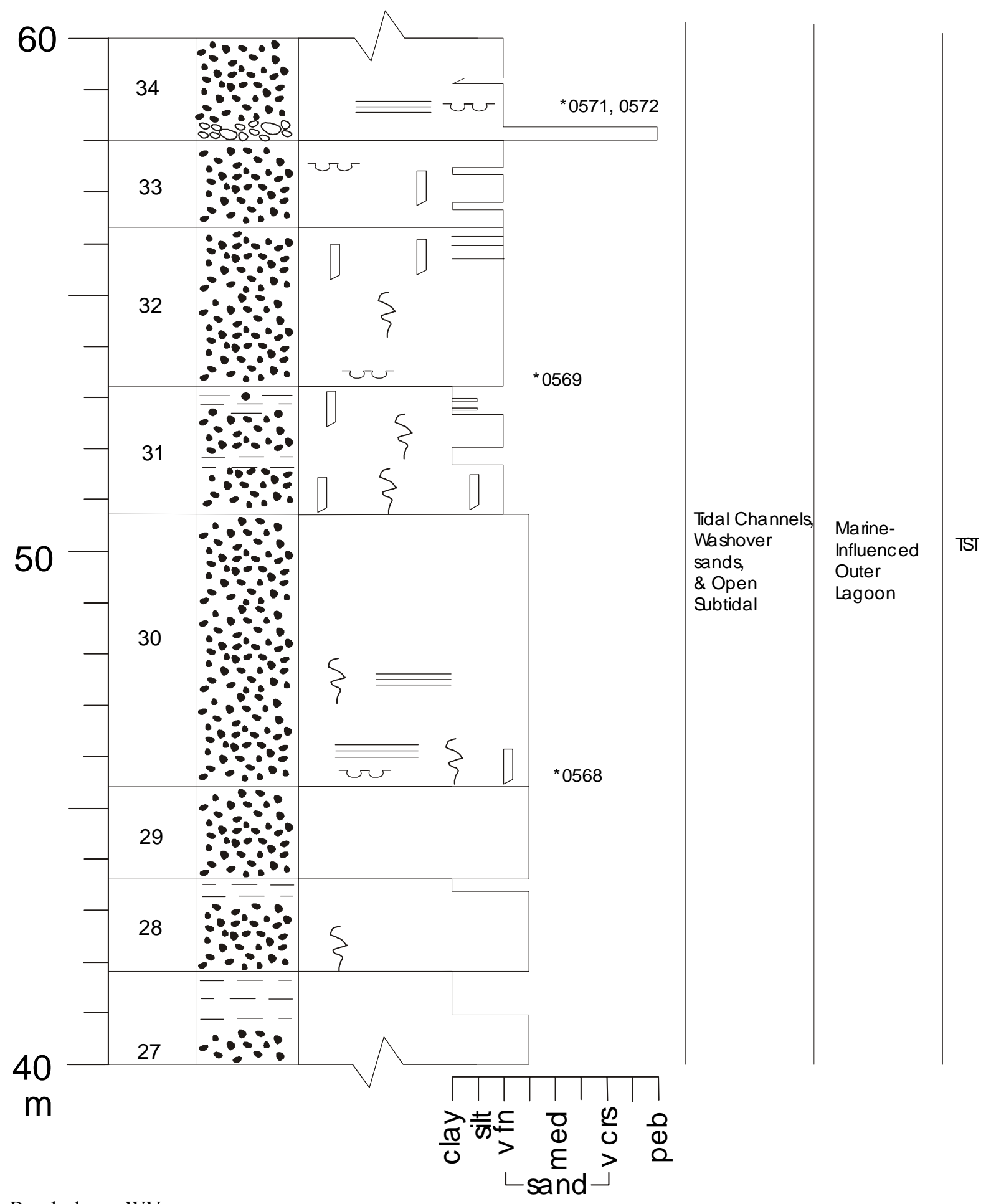

Rowlesburg, WV 


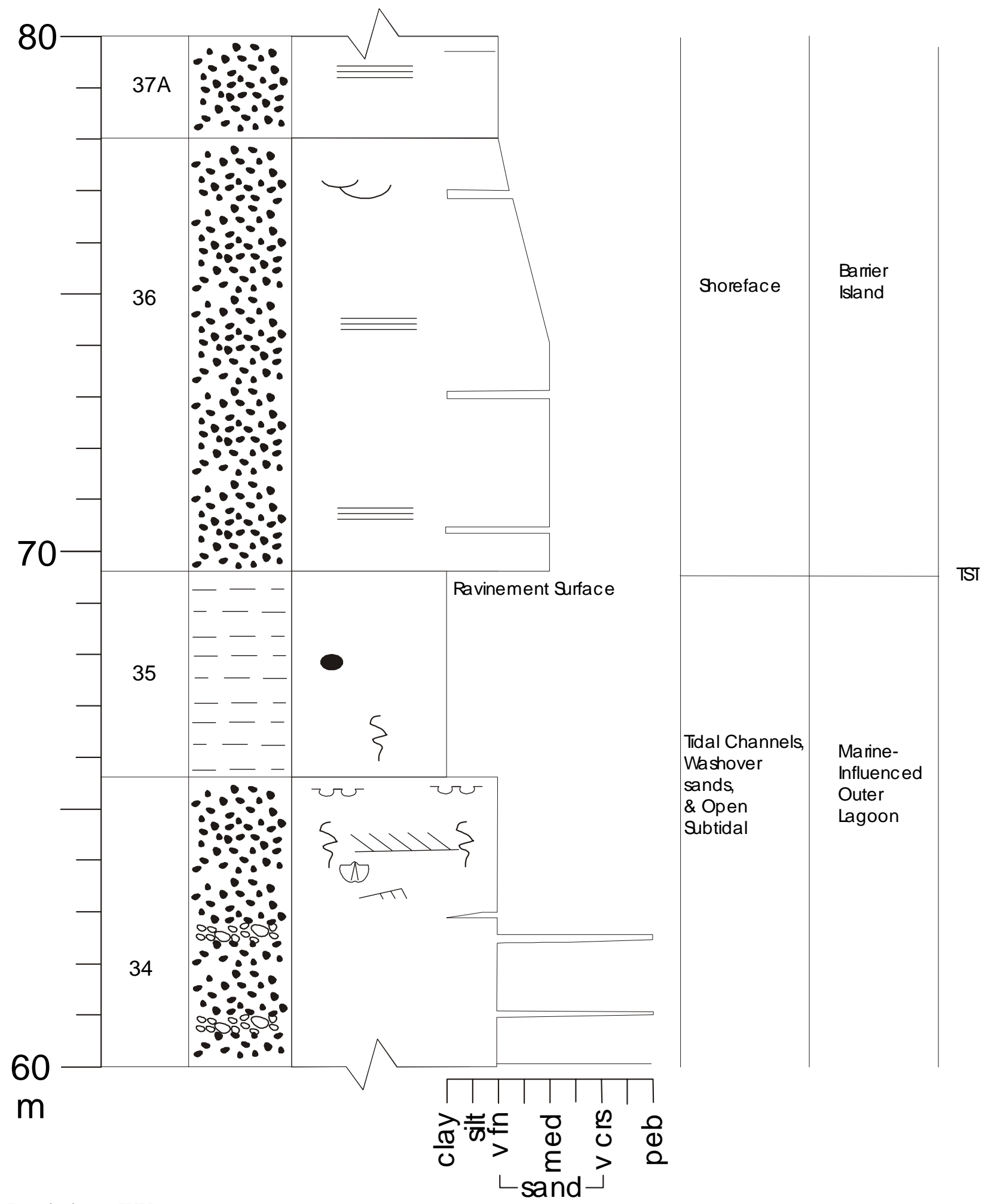

Rowlesburg, WV 


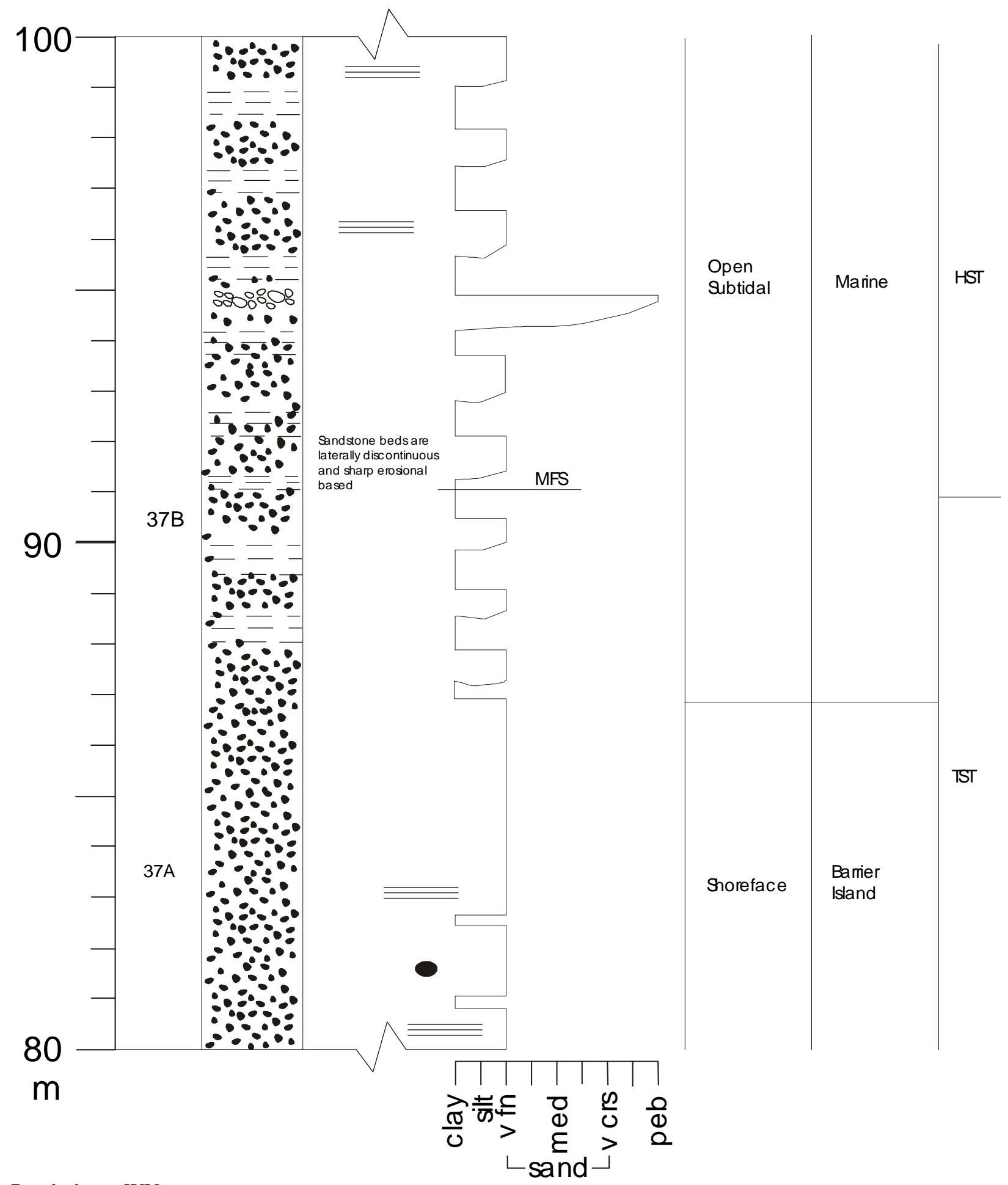

Rowlesburg, WV 


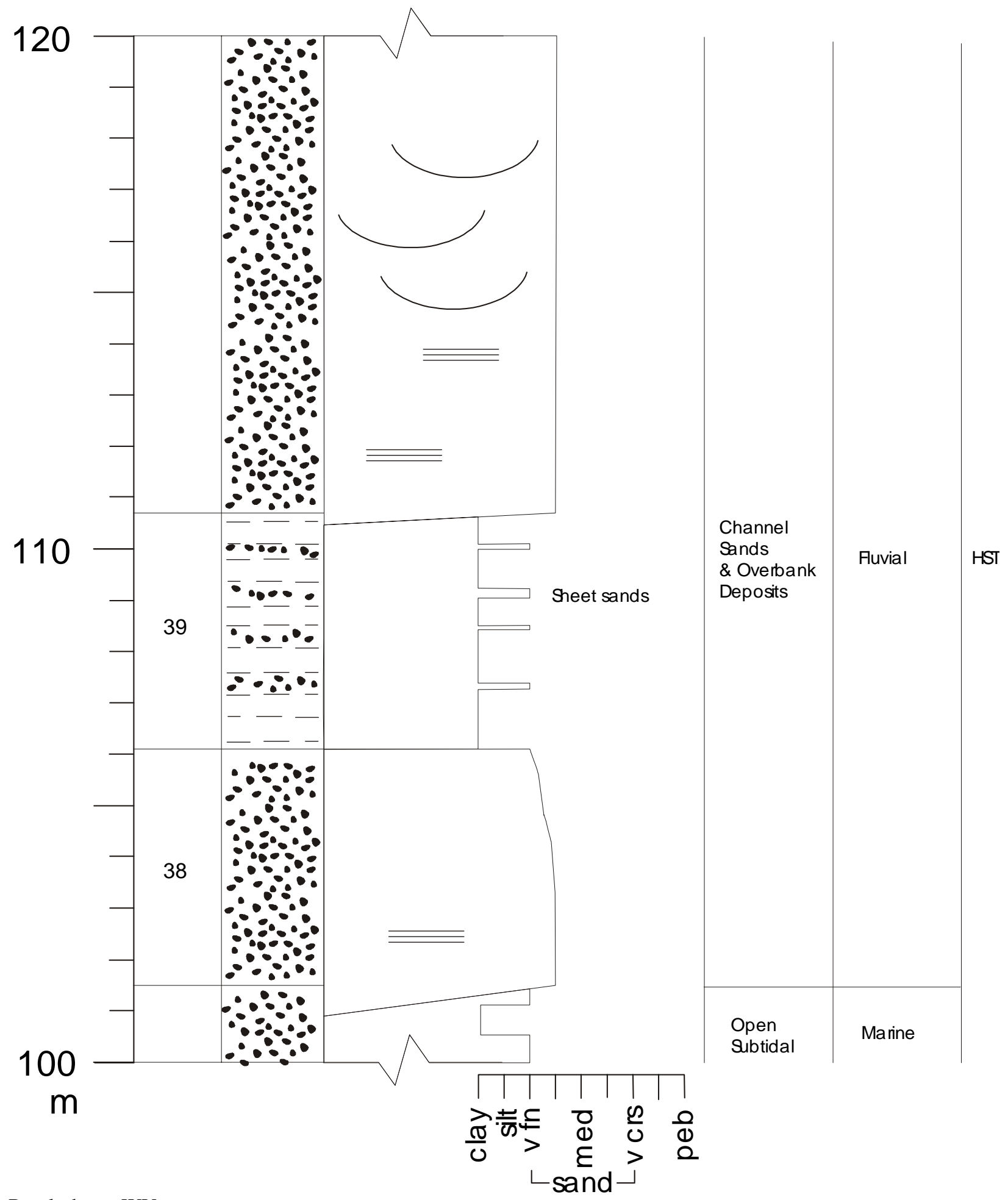

Rowlesburg, WV 


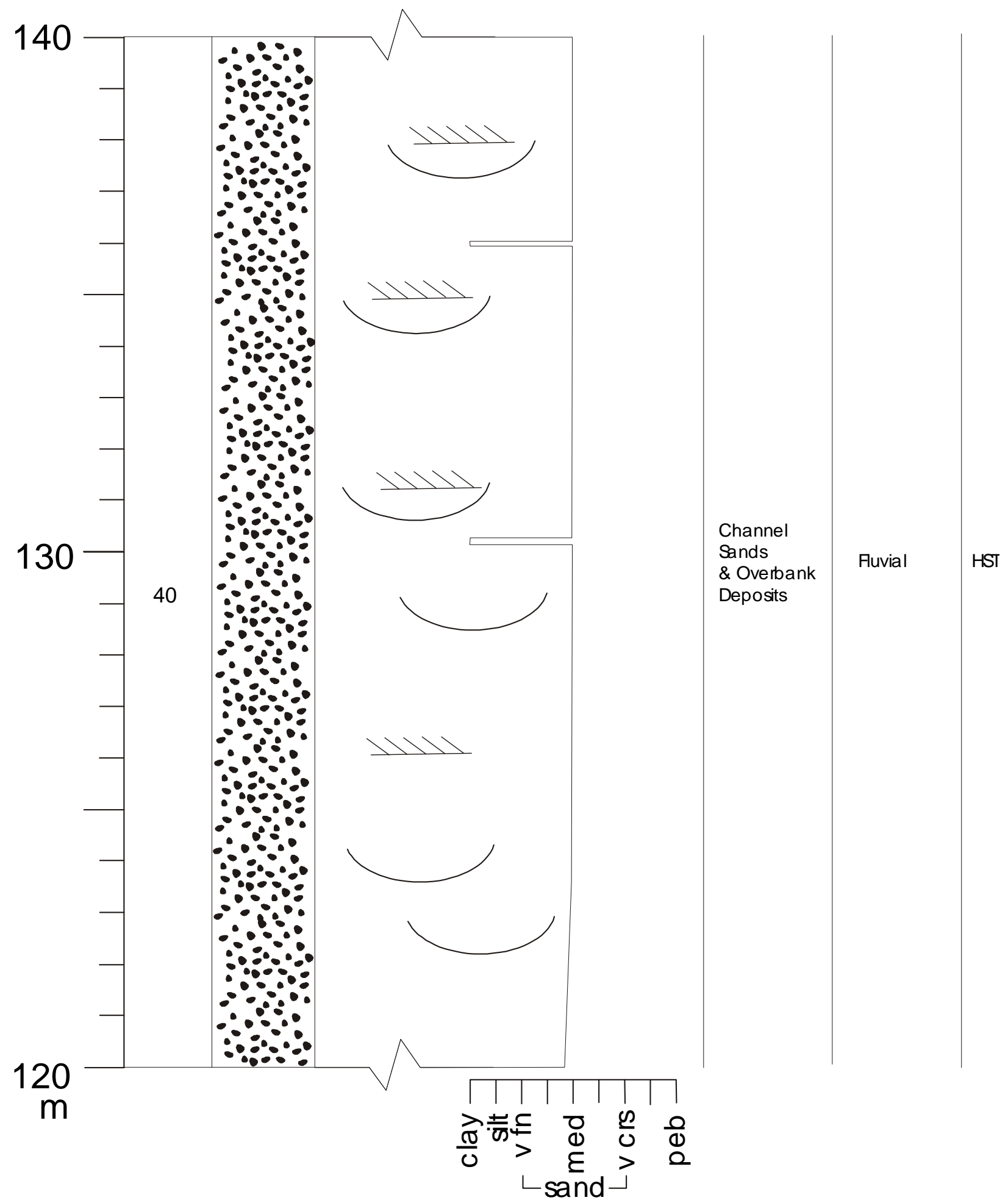

Rowlesburg, WV 


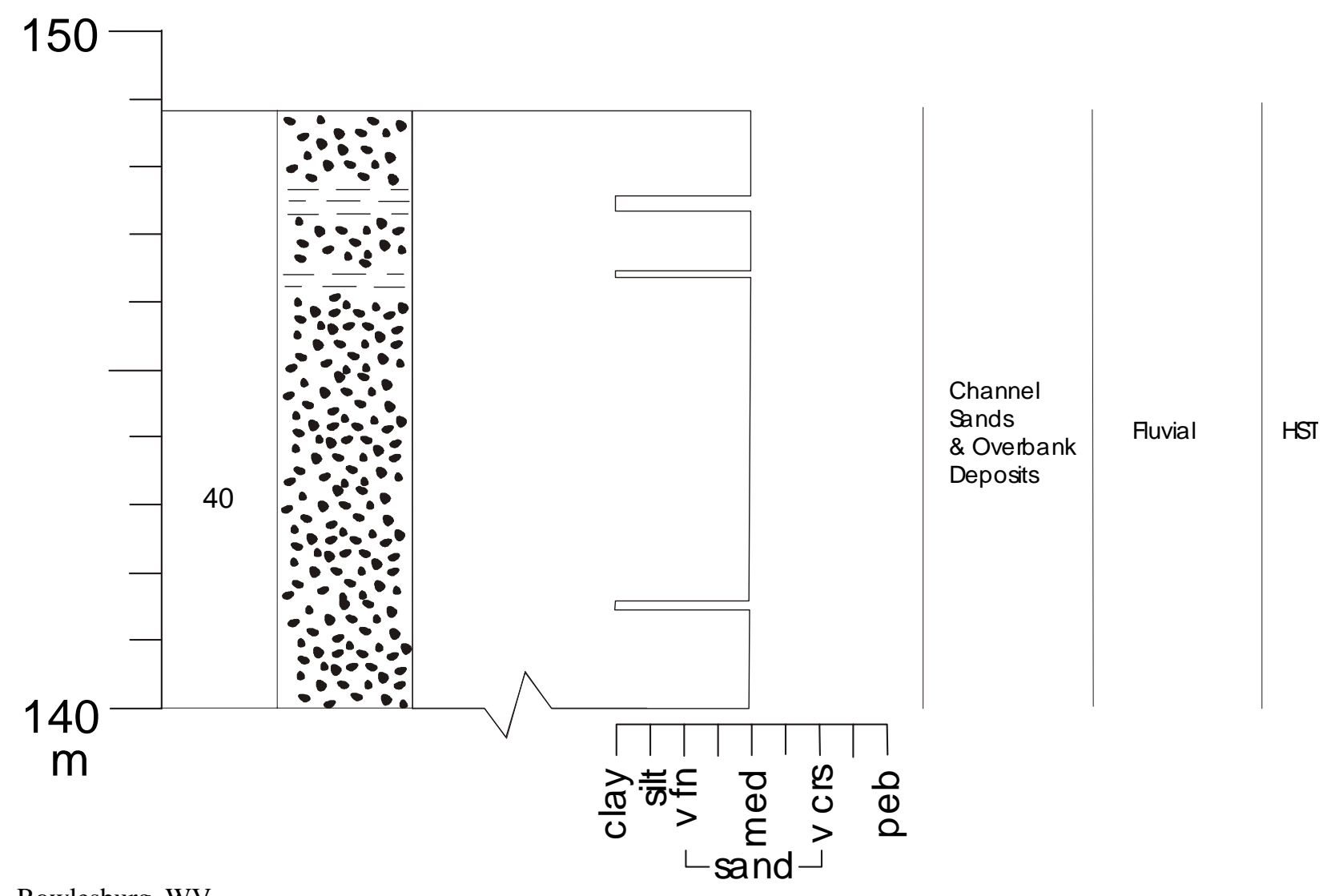

Rowlesburg, WV 


\section{KEYSERS RIDGE MARYLAND OUTCROP}


Keysers Ridge Outcrop

Location: Oakland MD. I-68 East, just west of exit 14b on the north side of the highway.

Date: Friday August 23, 2002

UNIT 1: Thickness $1.0 \mathrm{~m}(3.28 \mathrm{ft})$

Rock name - SHALE

Rock color - Dark gray

Bedding - Talus, mostly covered

Sed. Structures - No sedimentary structures observed

Trace \& body fossils - No trace or body fossils observed

Comments - Gradational basal contact

UNIT 2: Thickness $0.4 \mathrm{~m}(1.3 \mathrm{ft})$

Rock name - Fine-grained SANDSTONE

Rock color - Gray (fresh), green gray (weathered)

Bedding - Medium bedded

Sed. Structures - Minor ripples near top of unit

Trace $\&$ body fossils - Upper bedding surfaces are bioturbated

Comments - Sharp basal contact

UNIT 3: Thickness $2.5 \mathrm{~m}(8.2 \mathrm{ft})$

Rock name - SHALE to MUDSTONE

Rock color - Green to green-gray

Bedding - No bedding observed due to cover, unit is mostly talus

Sed. Structures - No sedimentary structures observed

Trace \& body fossils - No trace or body fossils observed

Comments - Unit is mostly covered but exposed outcrop is all talus. Upper $40 \mathrm{~cm}$ is a green-gray

MUDSTONE. Sharp basal contact.

UNIT 4: Thickness $0.8 \mathrm{~m}(2.6 \mathrm{ft})$

Rock name - Very fine-grained SANDSTONE with interbedded SHALE

Rock color - Sandstone is green-gray, shale is tan to gray

Bedding - Thin to medium bedded. Interbedded shale is fissile and weathers platy

Sed. Structures - No sedimentary structures observed.

Trace \& body fossils - No trace or body fossils observed

Comments - Sharp basal contact

UNIT 5: Thickness $0.8 \mathrm{~m}(2.6 \mathrm{ft})$

Rock name - SHALE

Rock color - Green to green-gray

Bedding - No bedding observed due to cover, unit is mostly talus

Sed. Structures - No sedimentary structures observed

Trace \& body fossils - No trace or body fossils observed

Comments - Sharp basal contact 
UNIT 6: Thickness $0.7 \mathrm{~m}(2.3 \mathrm{ft})$

Rock name - Fine-grained SANDSTONE with minor SILTSTONE and SHALE

Rock color - Gray (fresh), buff to tan (weathered)

Bedding - Mostly massive, shale is fissile

Sed. Structures - No sedimentary structures observed

Trace \& body fossils - No trace or body fossils observed

Comments - Shale is mostly near the top but interbedded and appears to contain soft sediment

deformation. Sharp undulatory scoured basal contact.

UNIT 7: Thickness $1.8 \mathrm{~m}(5.9 \mathrm{ft})$

Rock name - SHALE and interbedded SILTSTONE

Rock color - Gray to tan

Bedding - Very thin to thinly bedded and appears wavy

Sed. Structures - Shale contains minor laminations

Trace \& body fossils - No trace or body fossils observed

Comments - Unit contains coal stringers and plant debris. Gradational basal contact.

UNIT 8: Thickness $1.7 \mathrm{~m}$ (5.6 ft)

Rock name - Coaly SHALE

Rock color - Dark gray to black

Bedding - Highly fissile but not laminated with few very thinly bedded silty lenses

Sed. Structures - No sedimentary structures observed

Trace \& body fossils - No trace or body fossils observed

Comments - Unit is organic rich with abundant plant trash. Unit is mostly covered talus. The

lower $0.7 \mathrm{~m}$ is similar to UNIT 7. Coal is more prevalent near the top. Gradational basal contact.

UNIT 9: Thickness $2.2 \mathrm{~m}(7.2 \mathrm{ft})$

Rock name - Fine-grained SANDSTONE

Rock color - Green-gray (fresh), rusty yellow (weathered)

Bedding - Medium to thickly bedded with few very thin shale beds

Sed. Structures - No sedimentary structures observed due to bioturbation

Trace \& body fossils - Large vertical burrows throughout and horizontal burrows on upper bedding surfaces. No body fossils observed.

Comments - Plant trash scattered throughout. Sharp undulatory basal contact (possibly a scour base).

UNIT 10: Thickness $3.3 \mathrm{~m}$ (10.8 ft)

Rock name - Interbedded SHALE and SILTSTONE

Rock color - Dark gray

Bedding - At $2.5 \mathrm{~m}$ unit is hackly. Remainder is shale with few thinly bedded siltstones.

Sed. Structures - No sedimentary structures observed

Trace \& body fossils - No trace or body fossils observed

Comments - Abundant root traces at $2.5 \mathrm{~m}$, plant debris scattered throughout. Unit contains a thin coal layer at top. Sharp basal contact.

UNIT 11: Thickness $3.3 \mathrm{~m}(10.8 \mathrm{ft})$ 
Rock name - Medium- to coarse-grained SANDSTONE

Rock color - Gray (fresh), rusty brown-yellow (weathered)

Bedding - Thickly bedded

Sed. Structures - No sedimentary structures observed

Trace \& body fossils - Unit is mostly bioturbated, especially on the tops of bedding planes. Unit contains horizontal burrows and abundant brachiopods. Some plant debris scattered throughout. Grain size is mostly medium but appeared coarse in places, no overall trend, unit also contained lithics. Sharp basal contact.

UNIT 12: Thickness $1.1 \mathrm{~m}(3.6 \mathrm{ft})$

Rock name - SHALY SILTSTONE

Rock color - Gray to green-gray

Bedding - Fissile to platy

Sed. Structures - No sedimentary structures observed

Trace \& body fossils - No trace or body fossils observed

Comments - Gradational basal contact

UNIT 13: Thickness - $2.1 \mathrm{~m}(6.9 \mathrm{ft})$

Rock name - Coarse- to medium-grained SANDSTONE

Rock color - Gray (fresh), tan to orange (weathered)

Bedding - Medium bedded

Sed. Structures - Highly cross-bedded throughout entire unit, mostly horizontal to low angle planar cross-stratification near top with some trough cross-bedding

Trace $\&$ body fossils - No trace or body fossils observed

Comments - Unit contains a conglomerate at base with sub to well rounded quartz pebbles.

Sharp scoured basal contact.

UNIT 14: Covered interval

UNIT 15: Thickness $1.6 \mathrm{~m}(5.2 \mathrm{ft})$

Rock name - Medium- to fine-grained SANDSTONE

Rock color - Gray at base to light gray at top

Bedding - Thin to medium bedded

Sed. Structures - Ripple to flaser bedded at base with abundant organics and mica flakes. Unit contains minor trough cross-stratification at $40 \mathrm{~cm}$ but is dominated by planar cross-

stratification. Some minor ripple beds at top of the Unit.

Trace \& body fossils - No trace or body fossils observed

Comments - Unit contains scattered unidentifiable black coarse sand sized particles, possibly organic matter. Base is mostly covered.

UNIT 16: Thickness $5.1 \mathrm{~m}(16.7 \mathrm{ft})$

Rock name - SHALE

Rock color - Dark gray (fresh), red-brown (weathered)

Bedding - Fissile and hackly

Sed. Structures - Relic laminations

Trace \& body fossils - No trace or body fossils observed 
Comments - Unit is mostly covered (talus) except for the upper $1.0 \mathrm{~m}$ that is exposed. Sharp basal contact.

UNIT 17: Thickness $1.8 \mathrm{~m}$ (5.9 ft)

Rock name - Very fine-grained SANDSTONE to SILTSTONE

Rock color - Dark gray (fresh), Red-brown to buff-brown (weathered)

Bedding - Thin to medium bedded, alternating sandstone and siltstone layers

Sed. Structures - Horizontal stratification but more rippled near the top

Trace \& body fossils - No trace or body fossils observed

Comments - Unit contains four $1 \mathrm{~cm}$ thick underclays with a green fungi growing within. Upper $10 \mathrm{~cm}$ contains very thin shale partings. Scattered iron nodules and plant trash throughout. Unit thickens to the east. Sharp basal contact.

UNIT 18: Thickness $1.7 \mathrm{~m}$ (5.6 ft)

Rock name - fine-grained SANDSTONE with interbedded MUDSTONE and SILTSTONE

Rock color - Sandstone is light gray (fresh), red-brown (weathered)

Bedding - Sandstone is thin to medium bedded. Mudstone and Siltstone bedding completely destroyed, appears to be a slope failure deposit.

Sed. Structures - No sedimentary structures observed

Trace \& body fossils - No trace or body fossils observed

Comments - Unit contains underclays. Conglomeratic layer (mostly shale clasts) at top of unit is poorly sorted and contains nodules. Sharp erosional basal contact.

UNIT 19: Thickness - $10.0 \mathrm{~m}(32.8 \mathrm{ft})$

Rock name - Fine- to medium-grained SANDSTONE

Rock color - Light gray (fresh), red-brown (weathered)

Bedding - Medium to thickly bedded

Sed. Structures - Horizontal-stratification changing to planar cross-stratification

Trace \& body fossils - No trace or body fossils observed

Comments - Sharp basal contact

UNIT 20: Thickness - $5.9 \mathrm{~m}(19.4 \mathrm{ft})$

Rock name - Medium-grained SANDSTONE

Rock color - White-gray (fresh), rusty-red (weathered)

Bedding - Medium to thickly bedded

Sed. Structures - Internally massive except for very top which contains trough crossstratification.

Trace \& body fossils - No trace or body fossils observed

Comments - Unit contains abundant plant debris and scattered shale clasts. Gradational undulatory basal contact. 


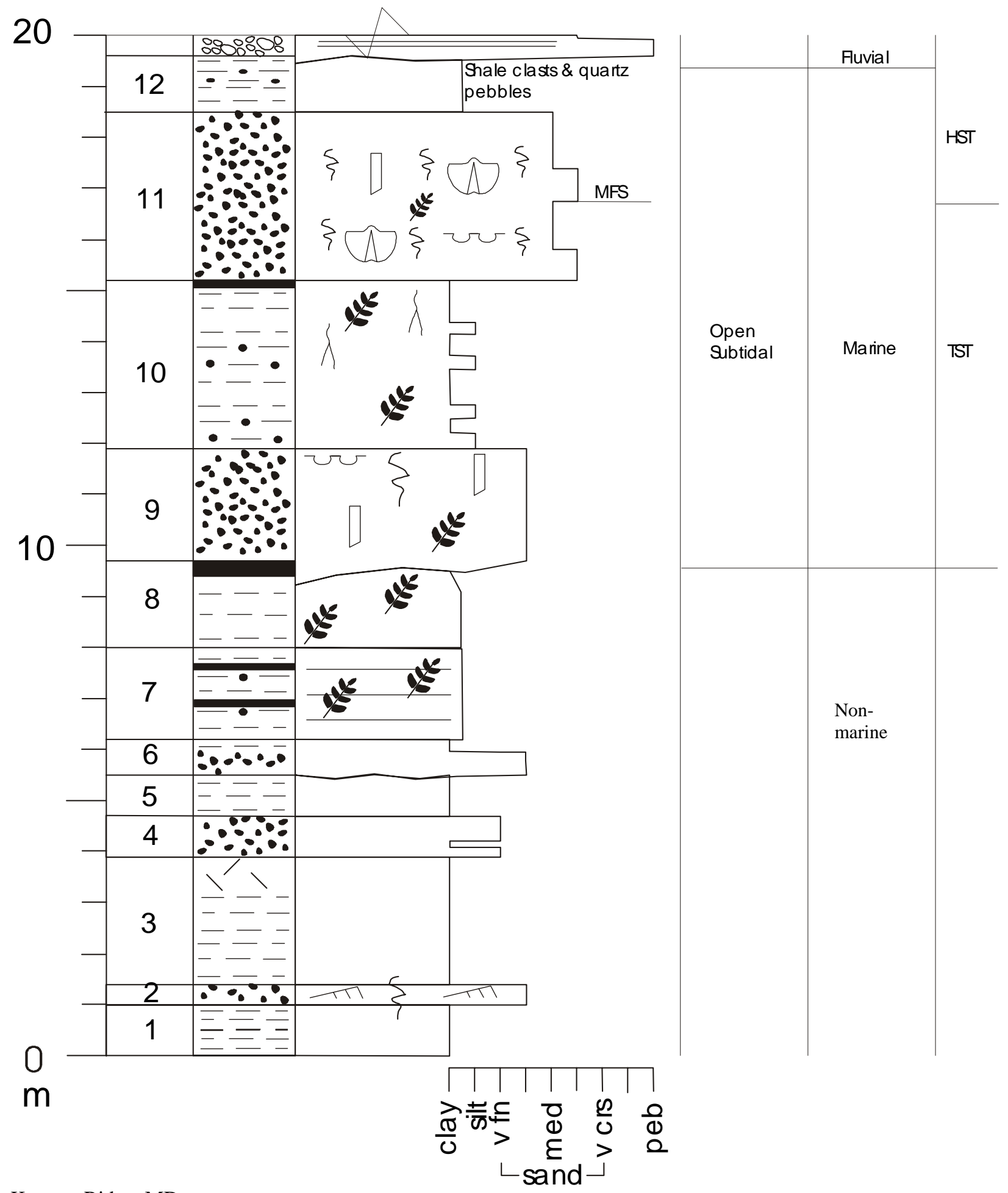

Keysers Ridge, MD 


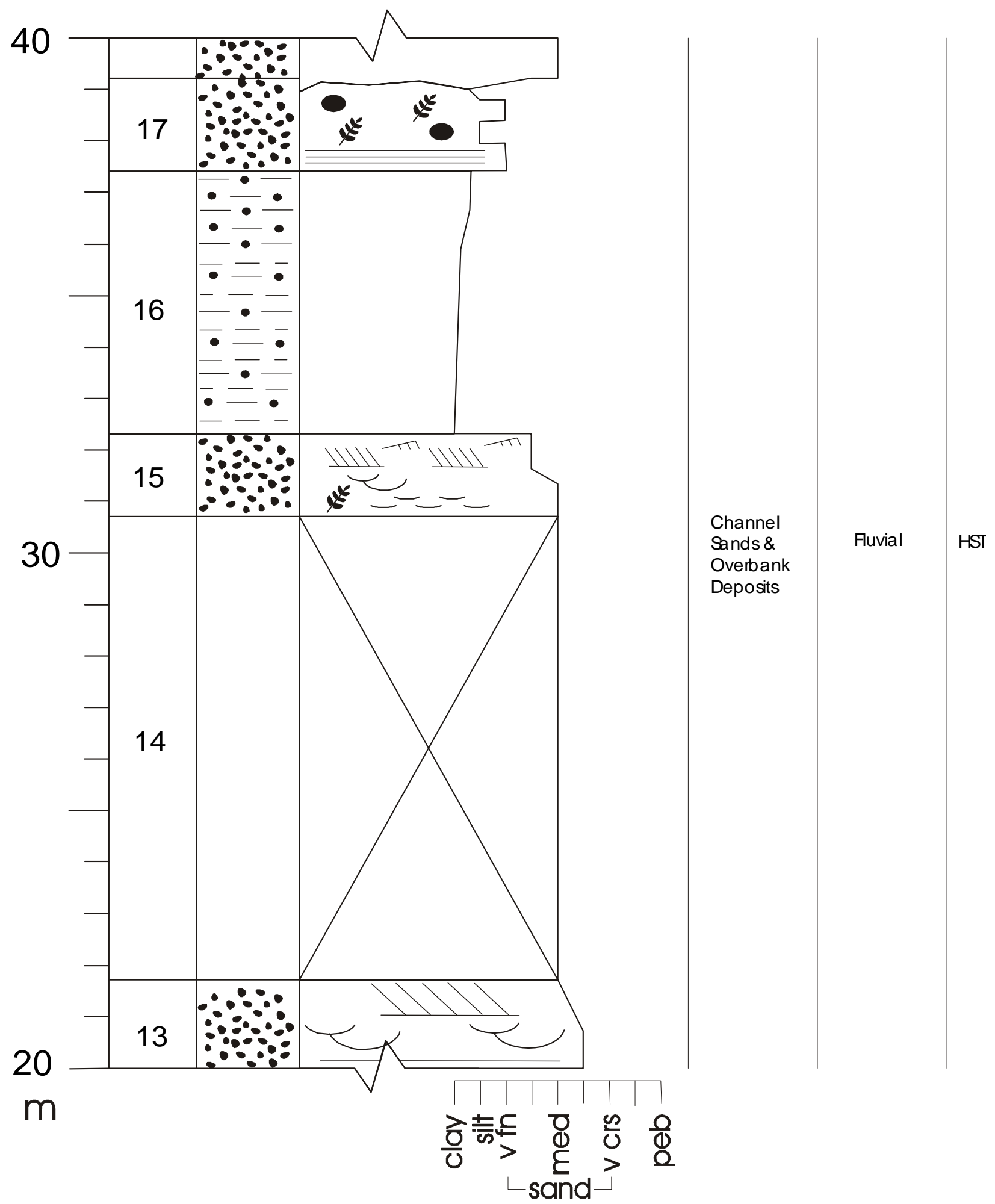

Keysers Ridge, MD 


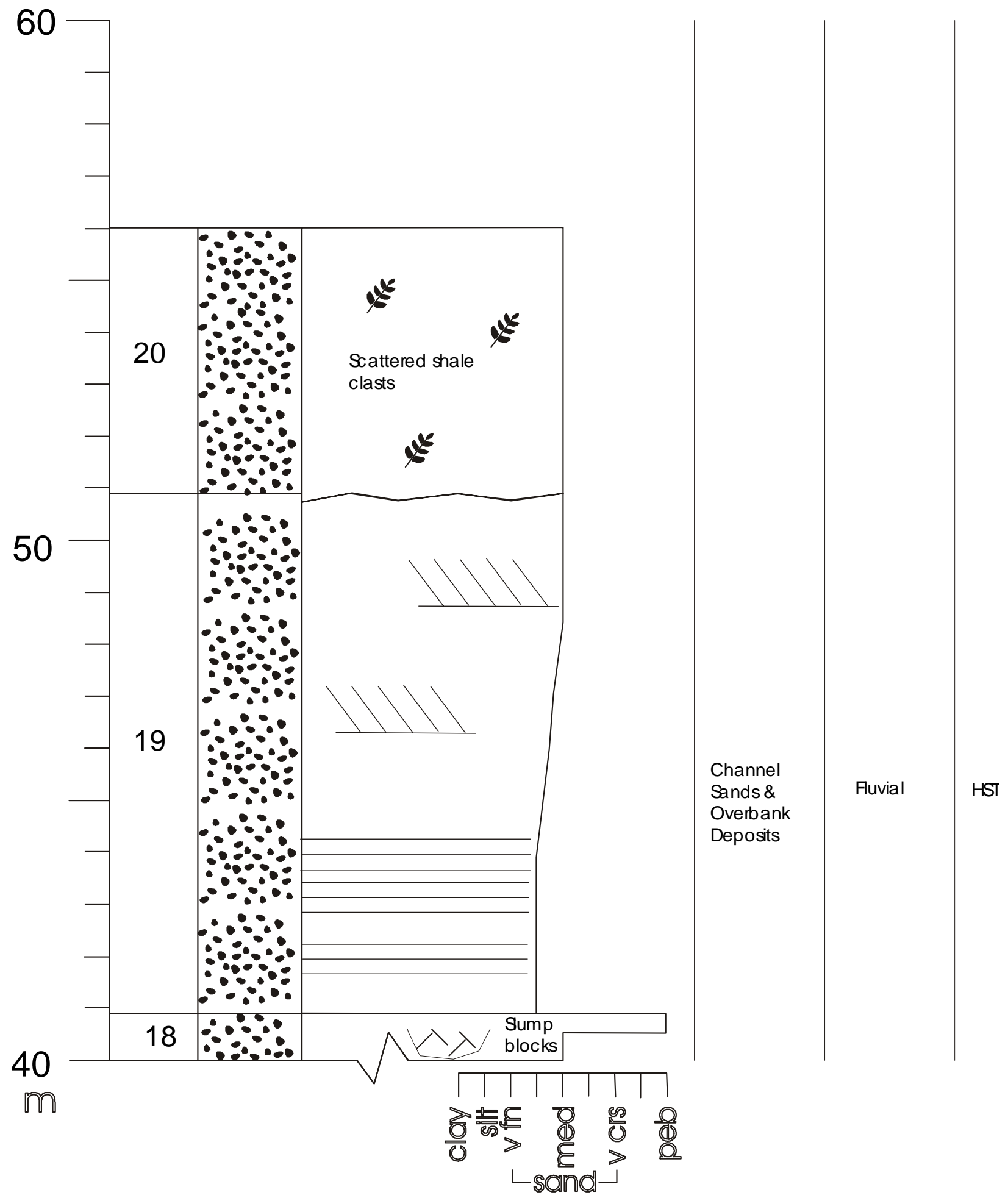

Keysers Ridge, MD 


\section{FINZEL MARYLAND OUTCROP}


Finzel Outcrop

Location: I-68 East, Finzel Md

Date: Saturday June 22, 2002

UNIT 1: Thickness - $0.45 \mathrm{~m}(1.48 \mathrm{ft})$

Rock name - SILTSTONE

Rock color - green-gray (fresh) and mottled. Yellow-brown (weathered), mottled red. Weathers blocky to crumbly and brittle.

Bedding - No bedding observed

Sed. Structures - No sedimentary structures observed

Trace \& body fossils - No trace or body fossils observed

Comments - Gradational basal contact with underlying paleosol.

UNIT 2: Thickness - $0.80 \mathrm{~m}(2.62 \mathrm{ft})$

Rock name - SILTSTONE to very fine-grained SANDSTONE

Rock color - Green-gray to dark gray (fresh). Yellow to orange-brown (weathered) mottled red.

Bedding - Blocky appearance, ledge former. Very thinly bedded siltstone traceable through unit.

Sed. Structures - No sedimentary structures observed

Trace \& body fossils - No trace or body fossils observed

Comments - Possible root traces, poorly developed. Some very fine mica flakes. Sharp basal

contact.

UNIT 3: Thickness - $1.4 \mathrm{~m}(4.59 \mathrm{ft})$

Rock name - Interbedded SHALE and SILTSTONE

Rock color - Dark gray (fresh). Rusty orange-brown (weathered).

Bedding - Basal shale thickly bedded $(35-40 \mathrm{~cm})$ with very thinly bedded siltstone layers. Four siltstone beds vary laterally from thin to medium bedded. Two lower siltstone beds are medium bedded to thinly bedded up-dip. Upper two siltstone beds maintain constant thickness.

Sed. Structures - Ripple and horizontal stratification in siltstone.

Trace \& body fossils - No trace or body fossils observed

Comments - Thickness varies laterally from underlying unit. Unit thins to the west (up-dip)

from $1.4 \mathrm{~m}$ to $1.0 \mathrm{~m}$. Gradational basal contact.

UNIT 4: Thickness - $2.5 \mathrm{~m}(8.20 \mathrm{ft})$

Rock name - SILTSTONE, very fine- to fine-grained SANDSTONE, interbedded SHALE

Rock color - Dark gray to green-gray (fresh). Yellow-brown to orange-brown (weathered).

Bedding - Sandstone is a prominent ledge former, shale has blocky texture and recessed. Some beds pinch-out up-dip, others maintain constant thickness. Beds are wavy interfingered siltstone and shale. Siltstone and sandstone beds are medium to thickly bedded. Shale is thin to very thinly bedded.

Sed. Structures - Siltstone is planar to ripple bedded near the base with very thin shale partings. Cross-bedding and ripple-bedding in lower portion of sandstone. Sandstone changes to massive above. Flazer bedding in sandstone near base.

Trace \& body fossils - Burrows (Cruziana ?) in lower most siltstone. Few faint burrows on bedding surfaces. Upper 3-5 cm of massive sandstone appears bioturbated. 
Comments - Unit thickness varies laterally. Unit appears to be channelized with siltstone/shale beds. Lower $60 \mathrm{~cm}$ thickens up-dip, above $60 \mathrm{~cm}$ unit maintains constant thickness. One channel body accounts for thickness change. Sharp scoured basal contact. Unit appears to coarsen upward.

UNIT 5: Thickness $-1.30 \mathrm{~m}(4.27 \mathrm{ft})$

Rock name - SILTSTONE

Rock color - Medium gray to green gray (fresh), light yellow to orange-brown (weathered). More orange-brown at top of unit.

Bedding - Unit has a blocky texture all throughout. Becomes hackly and more massive at top. Sed. Structures - No sedimentary structures observed

Trace \& body fossils - Possibly some faint relic traces (burrow or root ?). Possibly bioturbated at base.

Comments - Sharp basal contact.

UNIT 6: Thickness - $3.10 \mathrm{~m}(10.17 \mathrm{ft})$

Rock name - SHALE and SILTSTONE

Rock color - Dark gray (fresh), light tan orange to rusty brown (weathered).

Bedding - Basal $40 \mathrm{~cm}$ recessed, next $1.4 \mathrm{~m}$ becomes fissile and thinly bedded.

Sed. Structures - No sedimentary structures observed

Trace \& body fossils - No trace or body fossils observed

Comments - Siltstone becomes more abundant toward the top, shale grades out. Siderite nodules scattered throughout. Silt influx at $1.8 \mathrm{~m}$ very noticeable, shale content decreases and becomes less fissile upwards. Upper portion of unit contains yellow-green mottles *possible paleosol*. Gradational basal contact.

UNIT 7: Thickness $-0.85 \mathrm{~m}$ (2.79 ft)

Rock name - SHALE and SILTSTONE

Rock color - Shale green-gray (fresh \& weathered), siltstone is light gray (fresh) and greenyellow (weathered).

Bedding - Lower $40 \mathrm{~cm}$ is overpressured shale, fissile not laminated but highly compacted. 1 $\mathrm{cm}$ underclay at base. Very thin bedded siltstone interbedded in basal shale. Rest of unit mostly siltstone, massive, but slightly fissile.

Sed. Structures - No sedimentary structures observed

Trace \& body fossils - No trace or body fossils observed

Comments - Small scale C.U.S. Sharp basal contact.

UNIT 8: Thickness - $1.80 \mathrm{~m}(5.91 \mathrm{ft})$

Rock name - SILTSTONE w/interbedded SHALE. Very fine-grained SANDSTONE (upper 40 $\mathrm{cm})$

Rock color - Light gray (fresh \& weathered) 
Bedding - Lower $40 \mathrm{~cm}$ of unit 8 same as lower $40 \mathrm{~cm}$ of unit 7 . Upper portion contains two medium-thickly bedded siltstone beds with a medium-thick shale/siltstone bed on top. Shale is compacted and slightly fissile.

Sed. Structures - No sedimentary structures observed

Trace $\&$ body fossils - The two med-thick siltstone beds contain few vertical burrows and moderately bioturbated. Upper $40 \mathrm{~cm}$ of very fine-grained sandstone contains abundant burrows (possibly Skolithos).

Comments - Sharp basal contact

UNIT 9: Thickness - $1.80 \mathrm{~m}$ (5.91 ft)

Rock name - SHALE w/interbedded SILTSTONE and very fine-grained SANDSTONE (upper $30 \mathrm{~cm}$ )

Rock color - Green-gray (fresh), orange-brown and yellow-brown (weathered)

Bedding - Basal $80 \mathrm{~cm}$ is shale with very thinly bedded siltstone to thinly bedded very finegrained sandstone. Shale is fissile and deeply weathered. Upper $1.0 \mathrm{~m}$ is shale with very thinly bedded siltstone with abundant plant trash. Fissile and very crumbly weathering profile, contains siderite nodules. Sandstone at top of unit is $30 \mathrm{~cm}$, very fine-grained with a massive profile. Sed. Structures - No sedimentary structures observed Trace \& body fossils - No trace or body fossils observed Comments - Laterally unit becomes a large sandstone bed unmeasuarble in outcrop. Bed appears massive, a prominent ledge former. Weathers orange-brown. Bed pinches out 20 yards east of light pole at outcrop. Sandstone and siltstone beds contain abundant plant trash and scattered siderite nodules. Sharp basal contact.

UNIT 10: Thickness - $4.70 \mathrm{~m}(15.42 \mathrm{ft})$

Rock name - SHALE w/interbedded SILTSTONE

Rock color - Dark gray (fresh), light gray (weathered). Interbedded siltstone is gray (fresh) orange-brown (weathered).

Bedding - Shale is fissile to platy and compacted with relic laminations. Siltstone layers protrude out and shale is recessed. Siltstones are very thinly bedded at base to thinly bedded at top and lenticular.

Sed. Structures - Ripple marks were observed

Trace \& body fossils - No trace or body fossils observed

Comments - Unit contains siderite nodules. Sharp basal contact.

UNIT 11: Thickness -1.55 m (5.09)

Rock name - Fine-grained massive SANDSTONE

Rock color - Medium gray (fresh), orange-brown (weathered).

Bedding - There is a thin bedded siltstone $10 \mathrm{~cm}$ thick and $90 \mathrm{~cm}$ from base of unit. Sandstone beds are massive.

Sed. Structures - No sedimentary structures observed

Trace \& body fossils - At $80 \mathrm{~cm}$ from base 1 prominent vertical burrow about $5.0 \mathrm{~cm}$ long and $5.0 \mathrm{~mm}$ wide. Top $15 \mathrm{~cm}$ bioturbated. Siltstone bed appears to have faint relic burrows. Comments - Sharp undulatory basal contact.

UNIT 12: Thickness - $0.50 \mathrm{~m}(1.64 \mathrm{ft})$ 
Rock name - Silty MUDSTONE

Rock color - Light gray (fresh), orange-brown (weathered) mottled rusty brown.

Bedding - Weathers blocky to hackly and crumbly texture. Thickest section is $50 \mathrm{~cm}$ and pinches out updip. Unit is recessed from units above and below.

Sed. Structure - No sedimentary structures observed

Trace \& body fossils - No trace or body fossils observed

Comments - Unit may be a poorly developed paleosol. Sharp basal contact based on weathering profile \& texture change.

UNIT 13 (L, M, \& U): Thickness - 18.8 m (61.68 ft)

LOWER $10 \mathrm{~m}$

Rock name - Medium- to fine-grained (fining-upward) SANDSTONE w/interbedded SHALE Rock color - Sandstone is light gray (fresh) tan-yellow (weathered). Shale is dark gray. Bedding - Sandstone is massive at base and weathers crumbly at top. Shale is fissile Sed. Structure - Planar and trough cross-stratification becoming horizontal stratification at the top of the sandstone.

Trace \& body fossils - No trace or body fossils observed

Comments - Base of unit has channel shaped coal seams. Plant trash scattered throughout.

Channel filled mud plugs and multiple internal scours. Erosional basal contact with mud clasts. MIDDLE $6 \mathrm{~m}$

Rock name - Fine- to very fine-grained SANDSTONE becoming silty toward top with interbedded SHALE

Rock color - Sandstone is dark gray, shale is dark gray to faint red

Bedding - Sandstone is medium to thickly bedded.

Sed. Structures - Sandstone contains small-scale ripple bedding throughout with some horizontal stratification, lenticular, and flaser bedding. Mud cracks were also observed.

Trace \& body fossils - No trace or body fossils observed

Comments - Sharp basal contact.

UPPER $2.80 \mathrm{~m}$

Rock name - Interbedded SHALE and SILTSTONE to very fine-grained SANDSTONE

Rock color - Shale is deep red to dark purple becoming mottled and light gray toward top.

Bedding - Shale is fissile. Siltstone to very fine-grained sandstone are medium bedded, prominent ledge formers, and traceable throughout unit.

Sed. Structures - Shale is laminated and siltstone contain ripples. Mud cracks were observed.

Trace \& body fossils - Brachiopods were observed

Comments - Unit contains scattered root traces with possible bioturbation. Unit is micaceous.

Gradational basal contact.

UNIT 14: Thickness - $7.20 \mathrm{~m}(23.62 \mathrm{ft})$

Rock name - SHALE and MUDSTONE

Rock color - Dark gray to purple.

Bedding - Crumbly to hackly and weathers into slope. Mostly talus.

Sed. Structures - No sedimentary structures observed

Trace \& body fossils - No trace or body fossils observed

Comments - Sharp basal contact. 
UNIT 15: Thickness - $2.10 \mathrm{~m}$ (6.89 ft)

Rock name - SILTSTONE to very fine-grained SANDSTONE

Rock color - Siltstone dark gray (fresh) red-brown (weathered). Sandstone is light gray. Bedding - Siltstone weathers platy with interbedded shale. Sandstone is medium bedded.

Sed. Structures - Occasional ripples in siltstone beds

Trace \& body fossils - No trace or body fossils observed

Comments - Unit is very micaceous with plant trash scattered throughout. Sharp basal contact.

UNIT 16: Thickness - $6.0 \mathrm{~m}(19.69 \mathrm{ft})$

Rock name - SHALE

Rock color - Deep red to dark gray

Bedding - Weathers hackly, talus slope

Sed. Structures - No sedimentary structures observed

Trace \& body fossils - No trace or body fossils observed

Comments - Sharp basal contact.

UNIT 17: Thickness - $5.70 \mathrm{~m}$ (18.70 ft). TOP OF SECTION (due to cover).

Rock name - Interbedded fine-grained SANDSTONE, SILTSTONE and SHALE

Rock color - Sandstone is light gray to dark gray (fresh) tan to yellow-orange-brown (weathered)

Bedding - Base is interbedded siltstone \& shale. Sandstone is medium to thickly bedded

(thickness increases upward). Shale is interbedded, fissile, weathers platy to crumbly, a blocky appearance and more recessed. Sandstone massive at top of unit.

Sed. Structure - Planar cross-stratification at base to horizontal stratification at top within the upper sandstone bed. Sandstone has a scour base. Trace \& body fossils - No trace or body fossils observed Comments - Unit contains abundant plant trash. Sharp basal contact. 


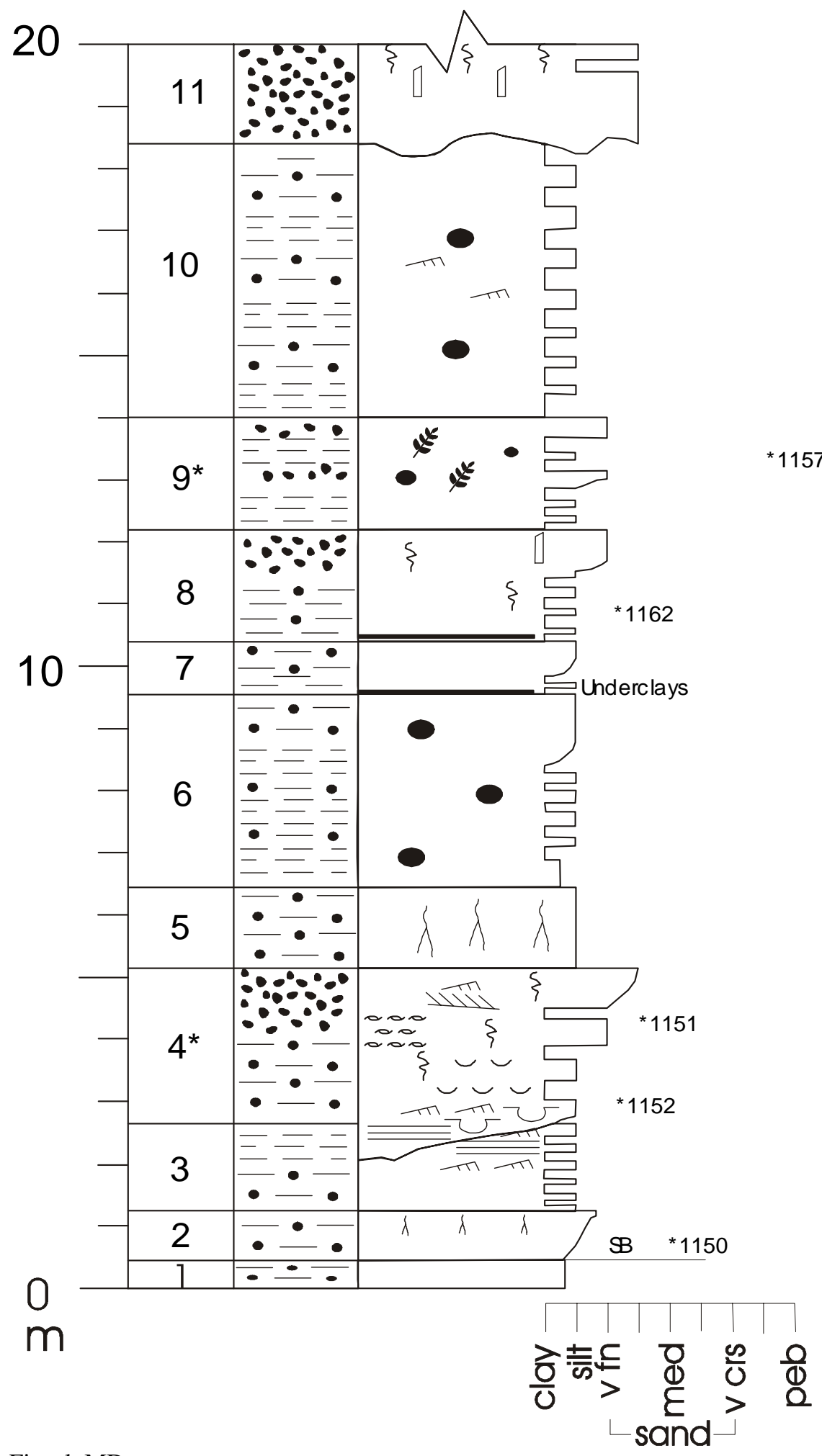

River-

Restric ted

Influenced

TST Subtidal

Inner Lagoon

Finzel, MD 


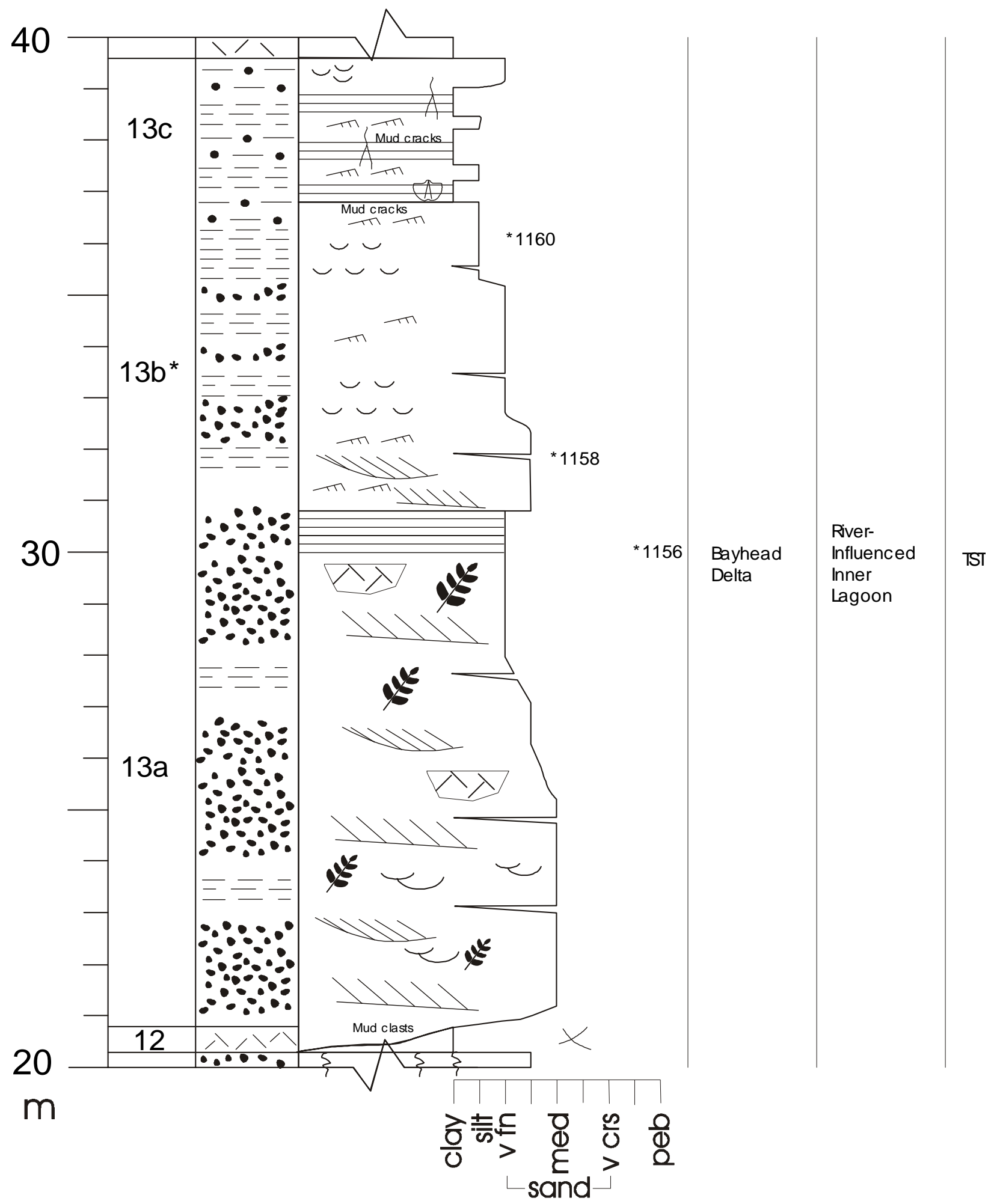

Finzel, MD 


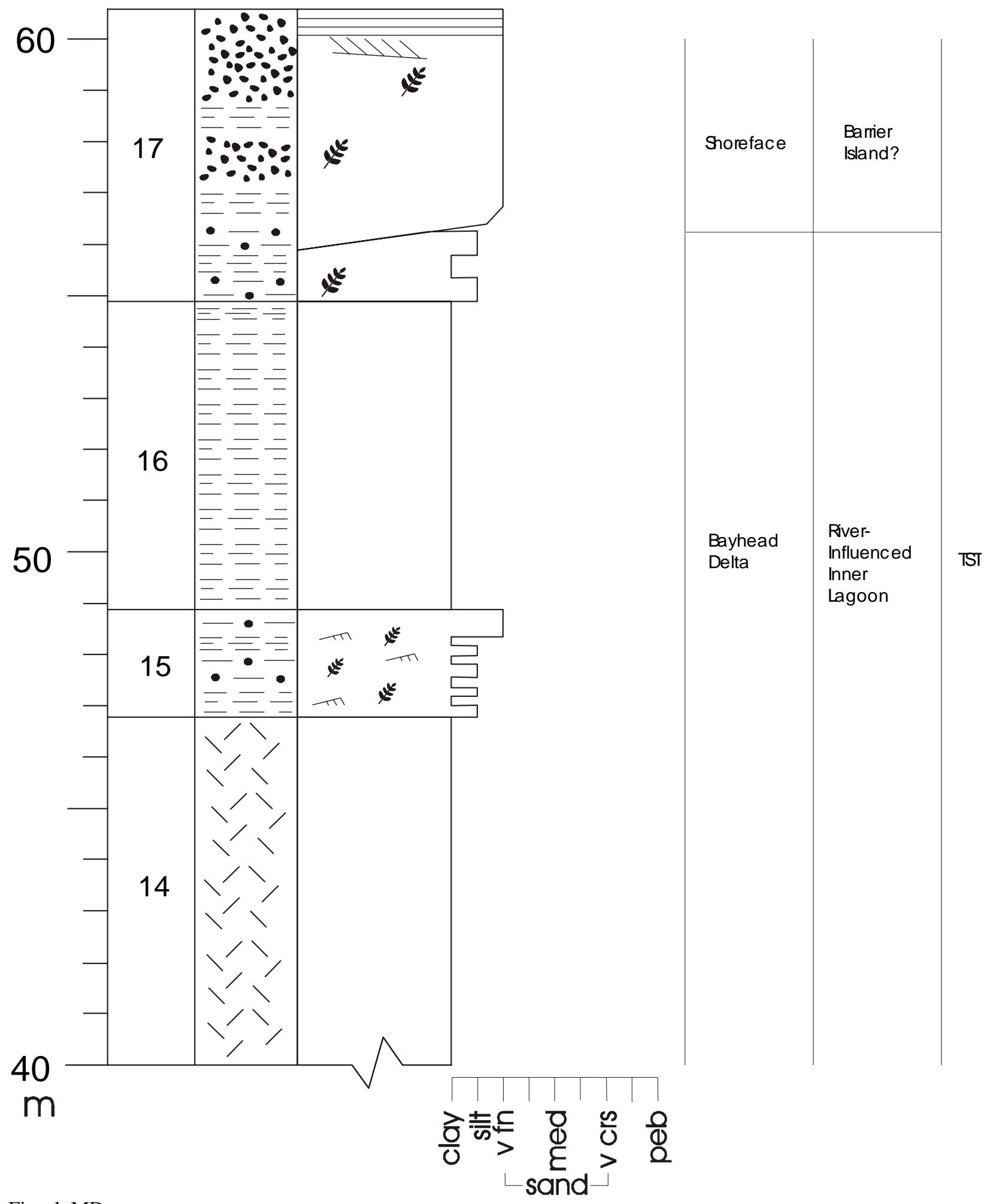

Finzel, MD 


\section{LAVALE MARYLAND \\ OUTCROP}


LaVale Outcrop

Date: Saturday July 6, 2002

Location: I-68 East, west of "gas exit 40" sign, Lavale MD.

UNIT 1: Thickness - $1.8 \mathrm{~m}$ (5.91 ft) F.U.S

Rock name - Interbedded very fine-grained to silty (fining up) SANDSTONE and SHALE

Rock color - Shale is red-brown, sandstone is light gray to brown.

Bedding - Unit is medium bedded at base to very thinly bedded at top. Interfingered thin

sandstone beds throughout. Unit has a crumbly weathered profile. Unit becomes more shaly

upward and sandstone becomes more silty. Top of unit is mostly red mudstone and shale.

Sed. Structures - Horizontal laminations.

Trace \& body fossils - No trace or body fossils observed

Comments - Sharp basal contact

UNIT 2: Thickness - $3.2 \mathrm{~m}(10.50 \mathrm{ft})$ F.U.S

Rock name - Very fine-grained SANDSTONE and SHALE

Rock color - Sandstone is gray-brown (fresh) and rusty brown to light gray (weathered). Shale is mottled gray.

Bedding - Sandstone is medium bedded and grades into shale, shale content increase upward.

Shale is blocky and crumbly.

Sed. Structure - No sedimentary structures observed

Trace \& body fossils - No trace or body fossils observed

Comments - Unit becomes shaly at top. About $2 \mathrm{~m}$ up from the base is a possible weakly

developed paleosol. Identified shell fragments at top of the unit. Gradational basal contact.

UNIT 3: Thickness - $3.1 \mathrm{~m}(10.17 \mathrm{ft})$

Rock name - Very fine- to fine-grained (fining up) SANDSTONE with small SHALE breaks in top $0.8 \mathrm{~m}$ of unit

Rock color - Sandstone is red-gray to green-gray at base of unit. Sandstone is dark gray (fresh)

and rusty brown (weathered) at top of unit. Shale breaks are green to rusty brown and mottled.

Bedding - Sandstone is massive and thickly bedded at base, becomes more massive at top. Shale breaks are small with a crumbly weathered texture.

Sed. Structures - Sandstone is internally laminated with some ripple bedding near base.

Trace \& body fossils - No trace or body fossils observed

Comments - Unit is very micaceous near base. Sharp erosional basal contact (1.5 m).

UNIT 4: Thickness - $3.3 \mathrm{~m}(10.83 \mathrm{ft})$

Rock name - Fine- to very fine-grained (fining up) SANDSTONE

Rock color - Light gray and some red (fresh) light gray to yellow-tan (weathered).

Bedding - Internally massive with mud lenses.

Sed. Structures - No sedimentary structures observed

Trace \& body fossils - Vertical burrows near top of unit.

Comments - Unit contains mud lenses encased in sandstone, possibly representing channel slumps. Gradational basal contact.

UNIT 5: Thickness - $1.2 \mathrm{~m}$ (3.94ft) C.U.S 
Rock name - Very fine to silty SANDSTONE w/interbedded SHALE

Rock color - Sandstone is green-gray to red-gray. Shale is gray to rusty gray (fresh) white-gray (weathered).

Bedding - Sandstone has a crumbly-blocky weathered texture, bedding is thick at base grading to thin at top of unit. Shale has a weathered crumbly texture, bedding is thin to medium.

Sed. Structures - No sedimentary structures observed

Trace \& body fossils - No trace or body fossils observed

Comments - UNIT 5 is recessed on the outcrop. Sharp basal contact based on weathering profile.

UNIT 6: Thickness - 2.4m (7.87 ft) C.U.S

Rock name - Fine-grained SANDSTONE w/interbedded SHALE

Rock color - Sandstone is dark gray (fresh) tan-green (weathered). Shale is red-brown.

Bedding - Sandstone is internally massive and thickly bedded with thin shale lenses. Shale has a blocky-hackly texture.

Sed. Structures - No sedimentary structures observed

Trace \& body fossils - No trace or body fossils observed

Comments - Sandstone at top of unit is slightly coarser than at base. Occasional mica flakes.

Sharp basal contact based on weathering profile.

UNIT 7: Thickness - $3.8 \mathrm{~m}(12.47 \mathrm{ft})$

Rock name - Fine-grained SANDSTONE with interbedded SHALE

Rock color - Sandstone is dark gray (fresh) light gray (weathered). Shale is red-gray to dark gray.

Bedding - Thin to medium bedded sandstone interbedded in shale. Sandstones progressively thicken upward to thickly bedded. Sandstone is laterally discontinuous. Sed. Structures - Shale is fissile but not laminated. Sandstone contains horizontal stratification.

Trace \& body fossils - No trace or body fossils observed

Comments - Unit contains micaceous layers. Gradational basal contact.

UNIT 8: Thickness - $2.6 \mathrm{~m}(8.53 \mathrm{ft})$

Rock name - SILTSTONE to fine-grained SANDSTONE (coarsening up) with interbedded SHALE

Rock color - Shale is dark gray, sandstone is light gray

Bedding - Shale is medium bedded near base and thins upward. Thin bedded siltstones near base thicken upward to medium bedded and coarsen to fine sandstone. Shale content decreases upward to partings between sandstone layers.

Sed. Structure - Shale is fissile but not laminated. No sedimentary structures observed within the sandstone.

Trace \& Body fossils - Tracks and trails on bedding surfaces in lower half of unit.

Comments - Weathering profile changes to more massive and blocky, some shale layers

throughout. Sandstone appears cleaner and more quartz cemented, possible pyrite grains with in sandstone. Gradational basal contact.

UNIT 9: Thickness - $2.7 \mathrm{~m}(8.86 \mathrm{ft})$ C.U.S

Rock name - Fine-grained SANDSTONE 
Rock color - Sandstone is light gray to tan (fresh) lighter gray (weathered).

Bedding - Medium to thickly bedded and thickens upward.

Sed. Structure - No sedimentary structures observed

Trace \& body fossils - Vertical burrows were identified along with possible bioturbation on top of some beds.

Comments - Scattered plant material within the sandstone. Shale partings throughout. Sharp

basal contact based on weathering profile.

UNIT 10: Thickness $-1.3 \mathrm{~m}$ (4.27 ft) C.U.S

Rock name - Fine- to medium-grained SANDSTONE

Rock color - Light gray to green-gray (fresh) lighter gray (weathered).

Bedding - Base is a shale break from the underlying unit. Sandstone above basal shale is $1.0 \mathrm{~m}$ thick and medium to thickly bedded. Sandstone thickens upward.

Sed. Structure - No sedimentary structures observed

Trace \& body fossils - Skolithos visible at top of the outcrop and partially along the road cut. Comments - Sandstone is slightly coarser grained than underlying unit. Unit contains some (organic black) plant trash. Sharp basal contact.

UNIT 11: Thickness - $2.8 \mathrm{~m}$ (9.19 ft) C.U.S

Rock name - Fine- to medium-grained SANDSTONE. Slightly coarser than underlying units. Rock color - Light gray to green-gray (fresh) lighter gray (weathered).

Bedding - Medium to thickly bedded sandstone. Sandstone beds thicken upward.

Sed. Structure - No sedimentary structures observed

Trace \& body fossils - Vertical burrows were identified along with possible bioturbation on the top of some beds. .

Comments - UNITS 9, 10, and 11 all show slight coarsening up and thickening up trends. Sharp basal contact.

UNIT 12: Thickness - $5.2 \mathrm{~m}(17.06 \mathrm{ft})$

Rock name - Very fine- to fine-grained SANDSTONE (coarsening up) with interbedded SILTSTONE and SHALE

Rock color - Sandstone is dark gray (fresh) light gray (weathered).

Bedding - Shale/siltstone is thin to medium bedded and discontinuous. Shale content decreases

upward. Sandstone is thickly bedded at the top of the unit (thickening up).

Sed. Structure - Shale is fissile but not laminated. There are some minor laminations in the silty shale near the base of the unit. No sedimentary structures were observed in the sandstone. Trace \& body fossils - No trace or body fossils observed

Comments - This unit is a mixture of sandstone and silty-shale. Gradational basal contact.

UNIT 13: Thickness - $3.0 \mathrm{~m}(9.84 \mathrm{ft})$

Rock name - Fine-grained SANDSTONE and thin SHALE partings

Rock color - Sandstone is green-gray at base and dark gray at top (fresh) tan (weathered). Shale is dark gray (fresh) and mottled throughout.

Bedding - Sandstone is thickly bedded. Shale is $20 \mathrm{~cm}$ thick at the very base of unit and weathers blocky to hackly. Remaining shale is thin continuous lenses within the sandstone. 
Sed. Structures - No sedimentary structures were observed in the sandstone. Basal shale contains pedigenic slickensides, possibly a paleosol.

Trace \& body fossils - No trace or body fossils observed

Comments - Sharp erosional basal contact (3.4 m).

UNIT 14: Thickness - $0.20 \mathrm{~m}$ (0.66 ft)

Rock name - Black carbonaceous SHALE

Rock color - Black and vitreous

Bedding - Fissile and platy

Sed. Structures - No sedimentary structures observed

Trace \& body fossils - No trace or body fossils observed

Comments - Sharp basal contact.

UNIT 15: Thickness - $4.1 \mathrm{~m}(13.45 \mathrm{ft})$

Rock name - SHALY MUDSTONE

Rock color - Base is light gray with red mottles (fresh) orange-red (weathered).

Weathered surface changes to a white-gray color at top.

Bedding - Weathers blocky to crumbly and upper half of unit becomes more fissile

Sed. Structures - No sedimentary structures observed

Trace \& body fossils - No trace or body fossils observed

Comments - Scattered plant trash throughout but more abundant at base. Large change from

mottled shale to black carbonaceous shale, mottling lessens upward. Gradational basal contact.

UNIT 16: Thickness - $1.7 \mathrm{~m}$ (5.58 ft)

Rock name - SHALE with interbedded very fine-grained SANDSTONE

Rock color - Shale is light gray to green gray. Sandstone is dark gray to red.

Bedding - Shale is fissile and content increases upward. Sandstone is medium bedded and lenticular at base to thinly bedded at top within shale.

Sed. Structure - Some minor ripples within shale beds. Lower sandstone contains small-scale low-angle planar cross-stratification.

Trace \& body fossils - No trace or body fossils observed

Comments - Gradational basal contact.

UNIT 17: Thickness - $1.9 \mathrm{~m}(6.23 \mathrm{ft})$

Rock name - Fine- to very fine-grained SANDSTONE

Rock color - light gray

Bedding - Massive with minor shale partings.

Sed. Structures - Ripple marks on top of bedding surfaces.

Trace \& body fossils - Possible traces along bedding surfaces and horizontal burrows in top of unit.

Comments - Sharp scour base contact.

UNIT 18: Thickness - $2.4 \mathrm{~m}$ (7.87 ft)

Rock name - SHALE with interbedded SILTSTONE

Rock color - Basal shale is dark brown to black. Top of unit becomes more reddish (weathered)

light gray (fresh) and mottled orange-red. 
Bedding - Top of unit is platy. Middle unit becomes more silty.

Sed. Structures - No sedimentary structures observed

Trace \& body fossils - No trace or body fossils observed

Comments - Unit is somewhat carbonaceous. Sharp basal contact.

UNIT 19: Thickness - $0.8 \mathrm{~m}(2.62 \mathrm{ft})$

Rock name - Silty to very fine-grained SANDSTONE

Rock color - Light gray (fresh) brown-tan (weathered)

Bedding - Discontinuous lenses of sandstone

Sed. Structures - Ripple marks on bedding surfaces

Trace \& body fossils - No trace or body fossils observed

Comments - Thin coal marks (probably tree branches) and plant material scattered throughout

unit. Gradational basal contact.

UNIT 20: Thickness - $1.1 \mathrm{~m}$ (3.61 ft)

Rock name - SHALE

Rock color - Light gray

Bedding - Weathers platy and somewhat fissile.

Sed. Structures - Ripple marks on bedding surfaces

Trace \& body fossils - No trace or body fossils observed

Comments - Coaly plant trash scattered throughout (same as UNIT 19). Gradational basal contact.

UNIT 21: Thickness - $20.5 \mathrm{~m}(67.26 \mathrm{ft})$

Rock name - Fine- to medium-grained (coarsening up) SANDSTONE

Rock color - Light gray (fresh) gray (weathered)

Bedding - Wedge shaped and discontinuous

Sed. Structure - Large scale bi-directional planar cross-stratification near base of unit and horizontally stratified at top

Trace \& body fossils - No trace or body fossils were observed

Comments -Sandstone contains shale clasts increasing upward with few thin shale lenses.

Internal scoured surfaces were observed. Sharp, erosional basal contact.

UNIT 22: Thickness - $2.2 \mathrm{~m}$ (7.22 ft)

Rock name - Fine- to medium-grained SANDSTONE with interbedded SHALE

Rock color - Light gray (fresh) gray (weathered)

Bedding - Thin to medium

Sed. Structure - No sedimentary structures observed

Trace \& body fossils - No trace or body fossils observed

Comments - Mostly covered gradational basal contact

UNIT 23: Thickness - $14.2 \mathrm{~m}$ (46.59 ft)

Rock name - DIAMICTITE

UNIT 24A \& B: Thickness - 18.5 m (60.70 ft) 
Rock name - Medium- to coarse-grained SANDSTONE

Rock color - Light gray to light tan

Bedding - Massive bedding. Overall, unit is tabular and thick to very thickly bedded. Some shale breaks near top of unit.

Sed. Structure - Small scale ripples near base, horizontal stratification in the middle, and large scale planar cross-stratification at top with minor trough cross-stratification.

Trace \& body fossils - No trace or body fossils observed

Comments -The middle portion of the unit is coarse-grained with visible individual quartz grains. Large shale break approximately $1.1 \mathrm{~m}$ thick roughly $15 \mathrm{~m}$ from the base of unit. This shale breaks separates 24A from 24B. Sandstone of 24B contains a basal conglomerate with abundant quartz pebbles. Sharp erosional basal contact $(1.0 \mathrm{~m})$.

UNIT 25: Thickness - $3.9 \mathrm{~m}$ (12.80 ft)

Rock name - SHALE with interbedded SANDSTONE and SILTSTONE

Rock color - Siltstone/sandstone is dark gray. Shale in upper half is green-red-brown (fresh) red-brown to rusty brown (weathered).

Bedding - Siltstone in lower half weathers blocky to platy. Shale in upper half weathers hackly.

Sed. Structures - No sedimentary structures observed

Trace \& body fossils - No trace or body fossils observed

Comments - Slickensides at the very top of the unit. Gradational basal contact.

UNIT 26: Thickness - $1.2 \mathrm{~m}$ (3.94 m)

Rock name - Fine-grained SANDSTONE

Rock color - Green-gray, mottled (fresh) green to red-brown (weathered)

Bedding - Massive and thickly bedded. Moderately hackly on surface

Sed. Structures - No sedimentary structures observed

Trace \& body fossils - No trace or body fossils observed

Comments - Unit contains slickensides. Gradational basal contact.

UNIT 27: Thickness - $1.0 \mathrm{~m}(3.28 \mathrm{ft})$

Rock name - SHALE

Rock color - Dark gray

Bedding - Hackly

Sed. Structures - No sedimentary structures observed

Trace \& body fossils - No trace or body fossils observed

Comments - Gradational basal contact.

UNIT 28: Thickness - $0.5 \mathrm{~m}$ (1.64 ft)

Rock name - Fine- to medium-grained SANDSTONE

Rock color - Sandstone is green-gray

Bedding - Internally massive, weathers blocky at top. Interbedded shale lenses.

Sed. Structure - No sedimentary structures observed

Trace \& body fossils - No trace or body fossils observed

Comments - Unit is continuous across outcrop. Gradational basal contact.

UNIT 29: Thickness - $7.4 \mathrm{~m}(24.28 \mathrm{ft})$ 
Rock name - SHALE

Rock color - Dark gray to red-brown

Bedding - Weathering profile is very jagged and recessed on outcrop, shale is hackly throughout.

Sed. Structures - No sedimentary structures observed

Trace \& body fossils - No trace or body fossils observed

Comments - Unit is recessed in center and very weathered. Sharp basal contact.

UNIT 30 (A, B, \& C): Thickness - 12.65 m (41.50 ft)

SUB-UNIT A : Thickness $-3.55 \mathrm{~m}$

Rock name - Fine-grained SANDSTONE

Rock color - Green to red (fresh) dark green-gray (weathered)

Bedding - Medium bedded

Sed. Structures - Planar cross-stratification at base to horizontal stratification

Trace \& body fossils - No trace or body fossils observed

Comments - Shale clasts scattered throughout. Unit may contain a slump block. Sharp

erosional basal contact $(1.5 \mathrm{~m})$.

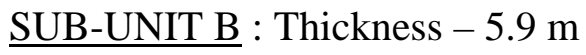

Rock name - Medium-grained SANDSTONE

Rock color - Reddish-gray

Bedding - Thickly bedded

Sed. Structures - No sedimentary structures observed

Trace \& body fossils - No trace or body fossils observed

Comments - Unit contains shale clasts. Gradational basal contact.

SUB-UNIT C : Thickness - $3.2 \mathrm{~m}$

Rock name - Fine-grained SANDSTONE with interbedded SHALE

Rock color - Light gray sandstone and shale is dark gray

Bedding - Sandstone is medium to thinly bedded upward.

Sed. Structures - Unit contains rippled mica layers

Trace \& body fossils - No trace or body fossils observed

Comments - Shale content increases upward. Gradational basal contact.

UNIT 31: Thickness - $11.7 \mathrm{~m}$ (38.39 ft)

Rockname - Fine-grained to slightly coarser SANDSTONE

Rock color - Red to dark gray (fresh)

Bedding - Wedge shaped and laterally discontinuous

Sed. Structures - Large-scale planar cross-stratification with horizontal stratification near the top

Trace \& body fossils - No trace or body fossils observed

Comments - Conglomeratic lenses at the base of the unit. Sharp erosional basal contact $(20 \mathrm{~cm})$.

UNIT 32: Thickness $2.5 \mathrm{~m}$ (8.20 ft) Top of Unit

Rockname - SHALE with interbedded fine-grained SANDSTONE

Rock color- Shale is red-brown. Sandstone is red to dark gray (fresh) and dark gray (weathered). Bedding - Sandstone is medium bedded 
Sed. Structures - Large scale planar cross-stratification in the sandstone. Mud or organic drapes over cross-beds.

Trace \& body fossils - No trace or body fossils observed

Comments - Sharp basal contact. 


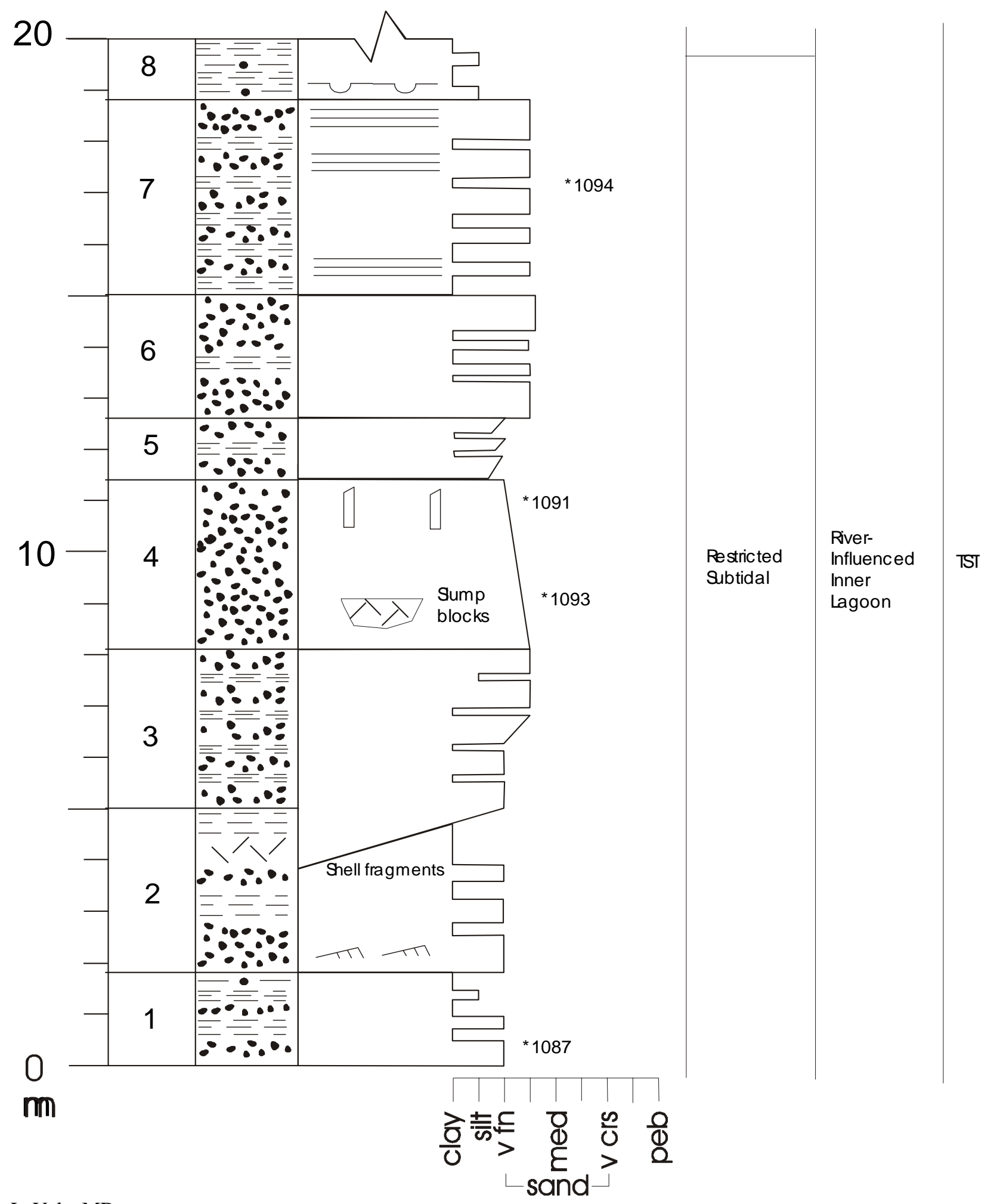

LaVale, MD 


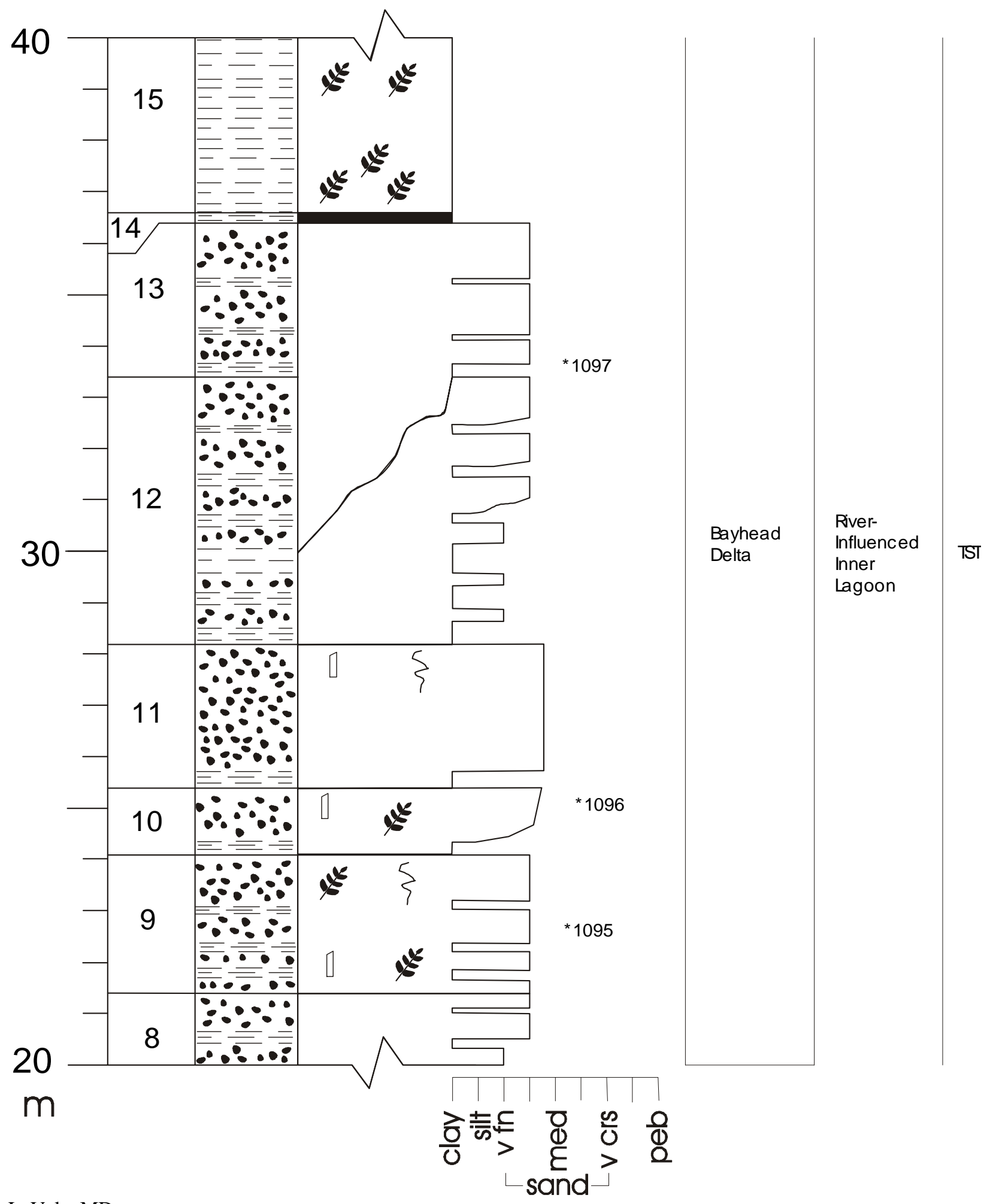

LaVale, MD 


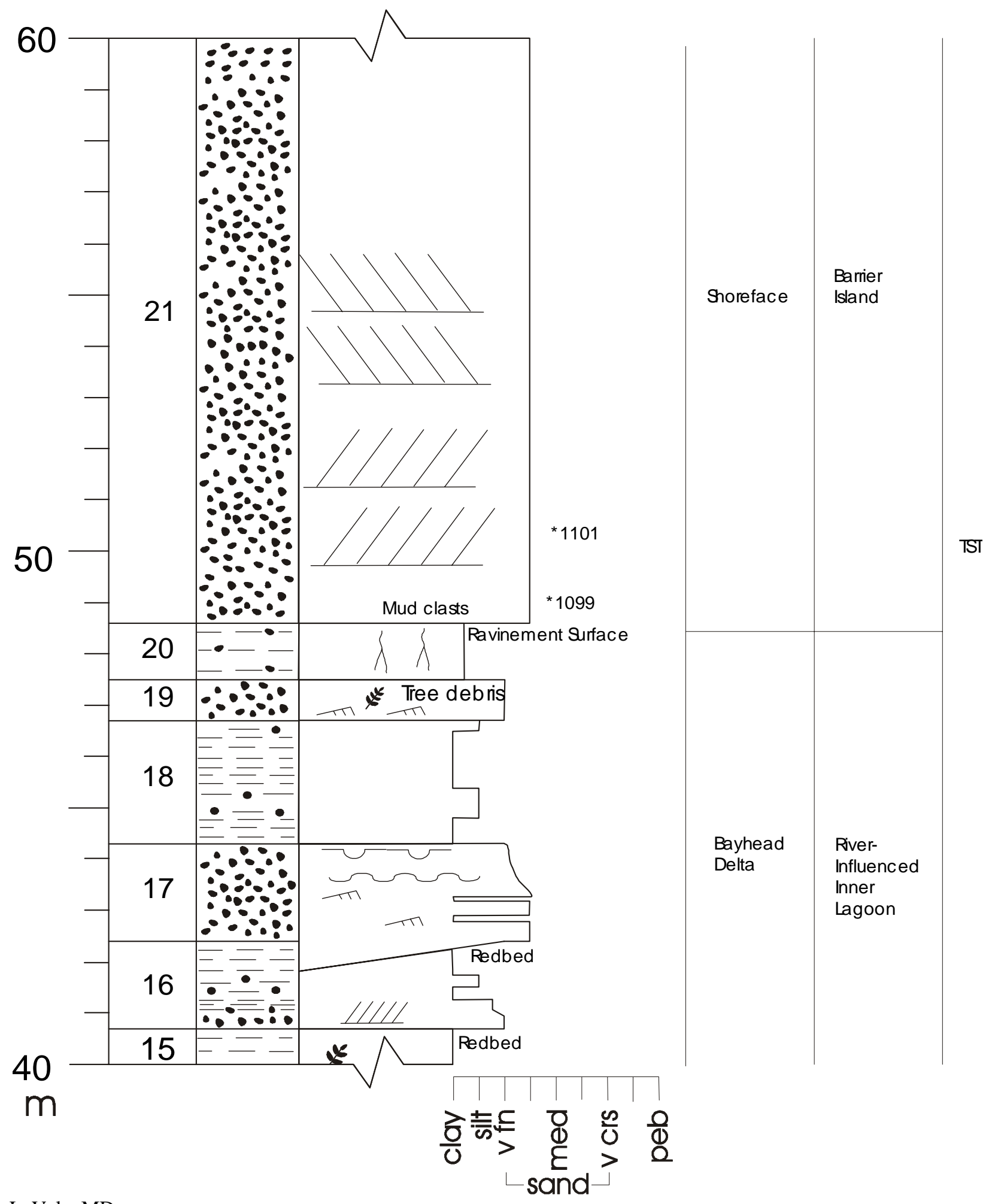

LaVale, MD 


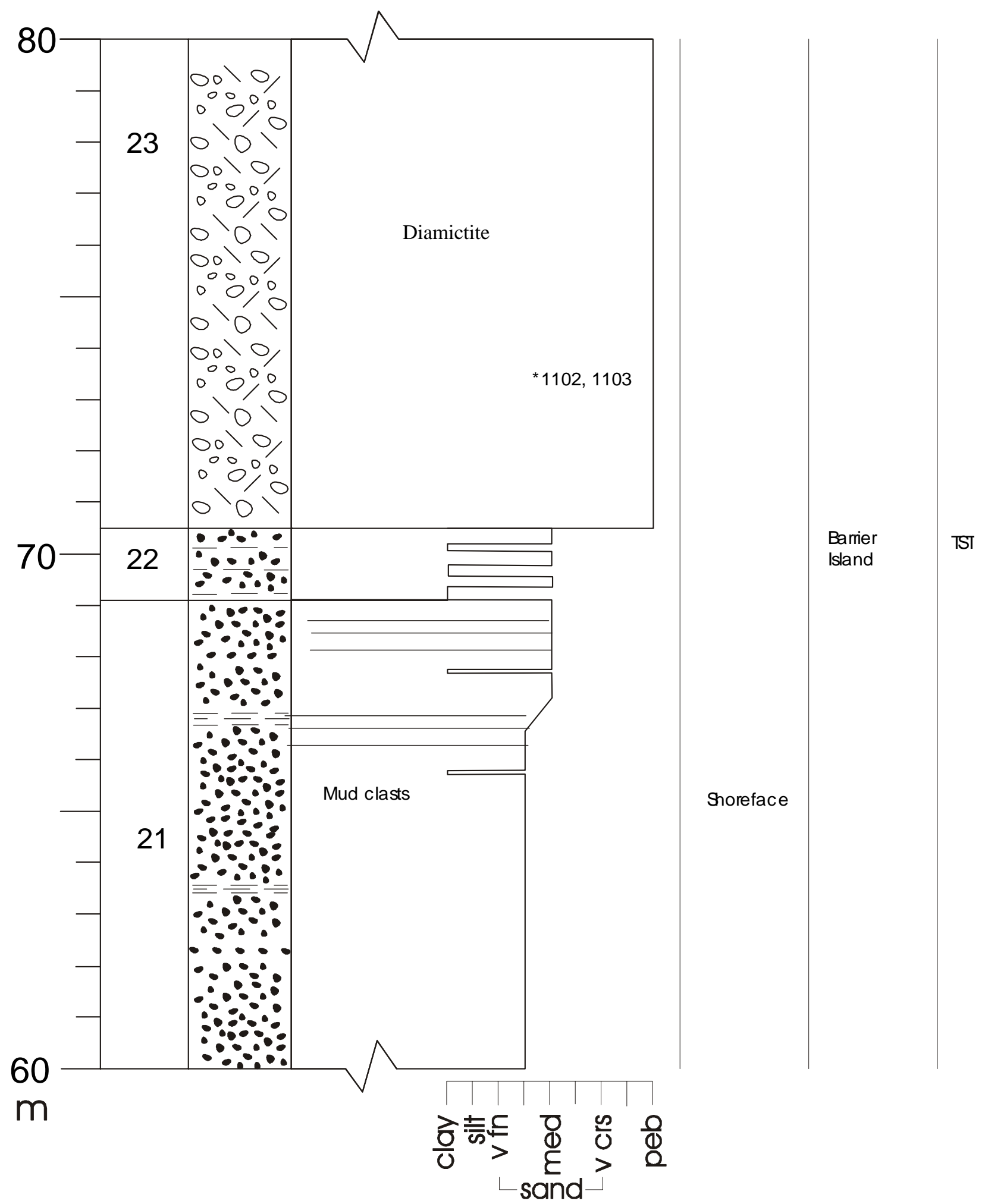

LaVale, MD 


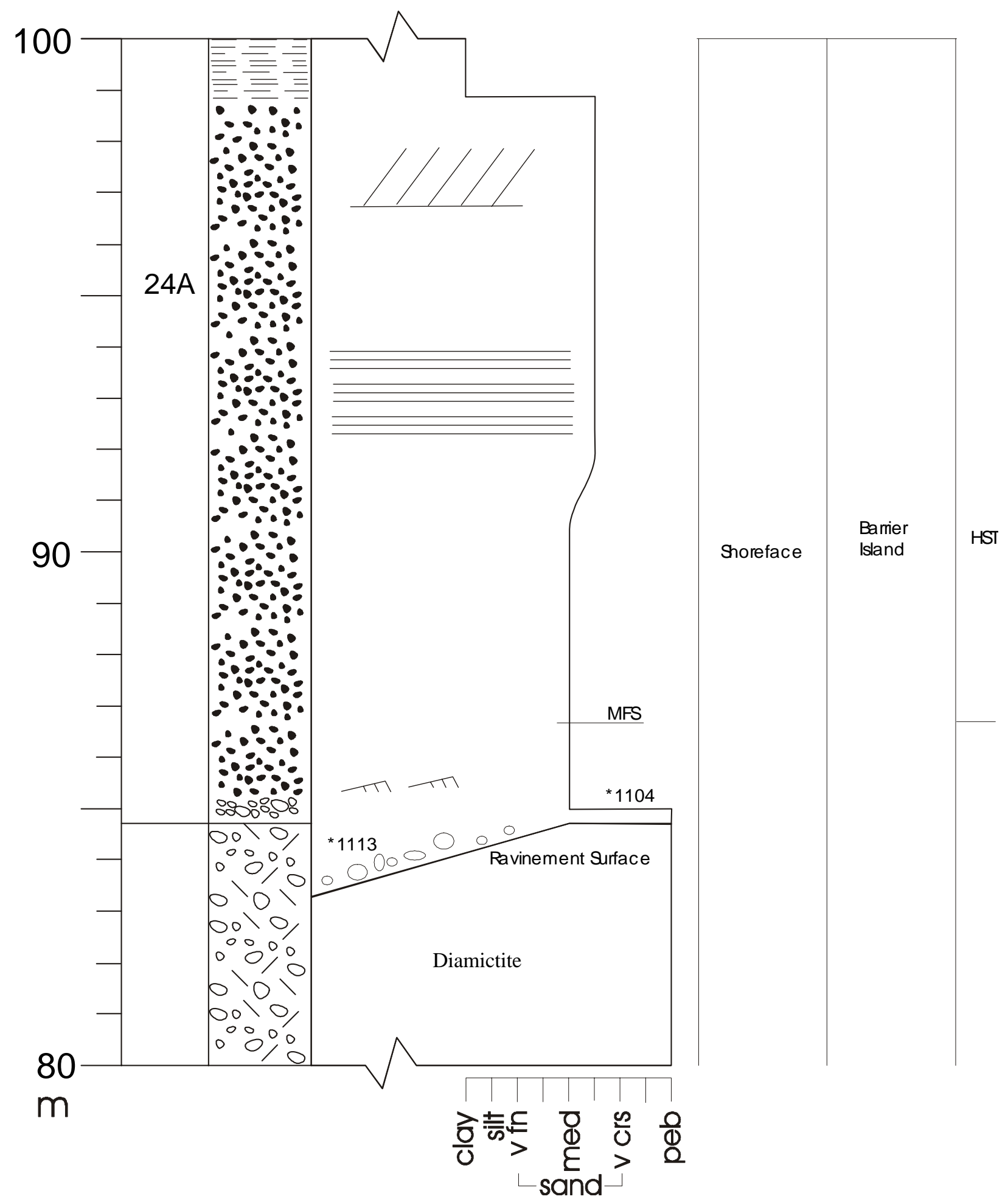

LaVale, MD 


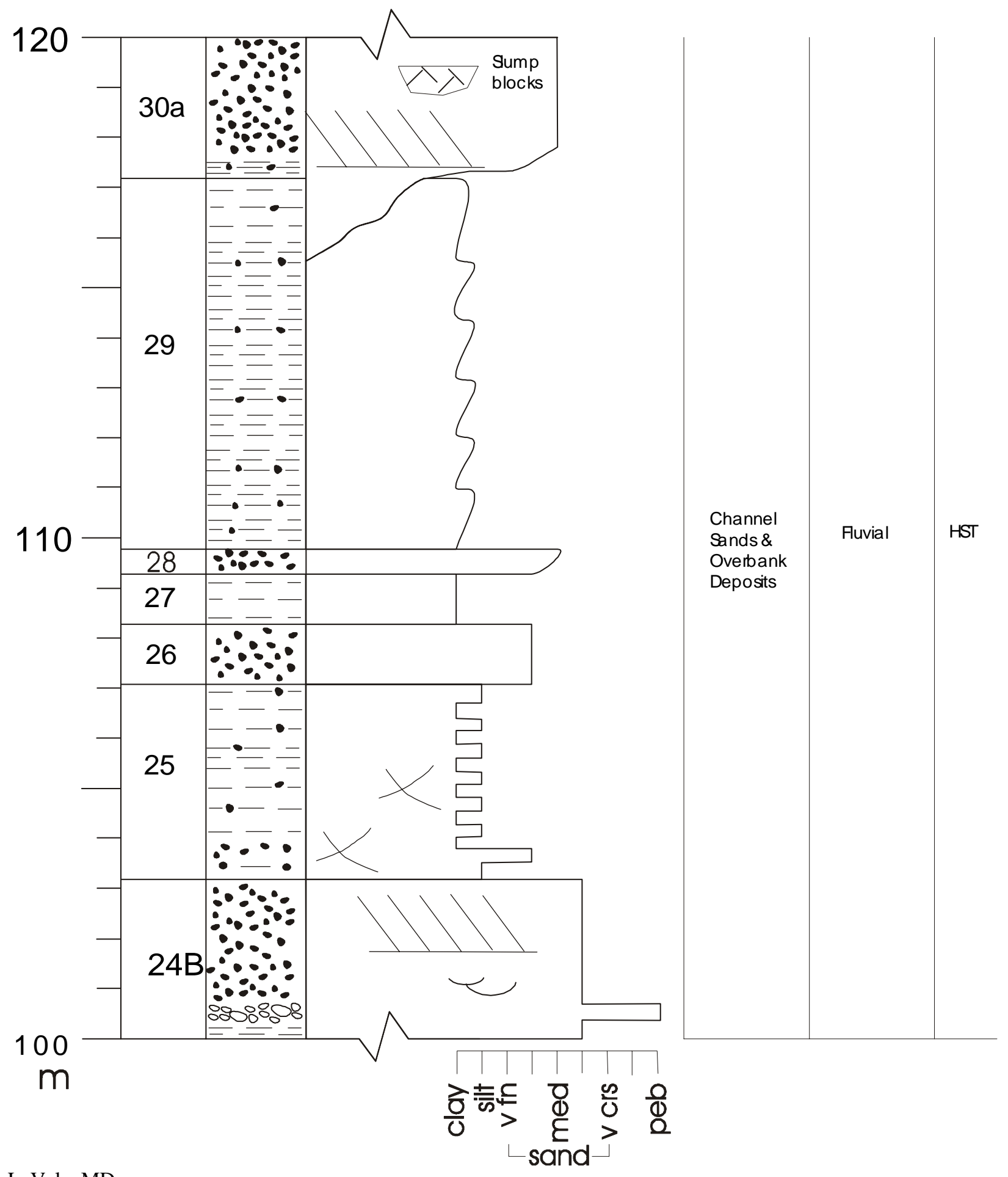

LaVale, MD 


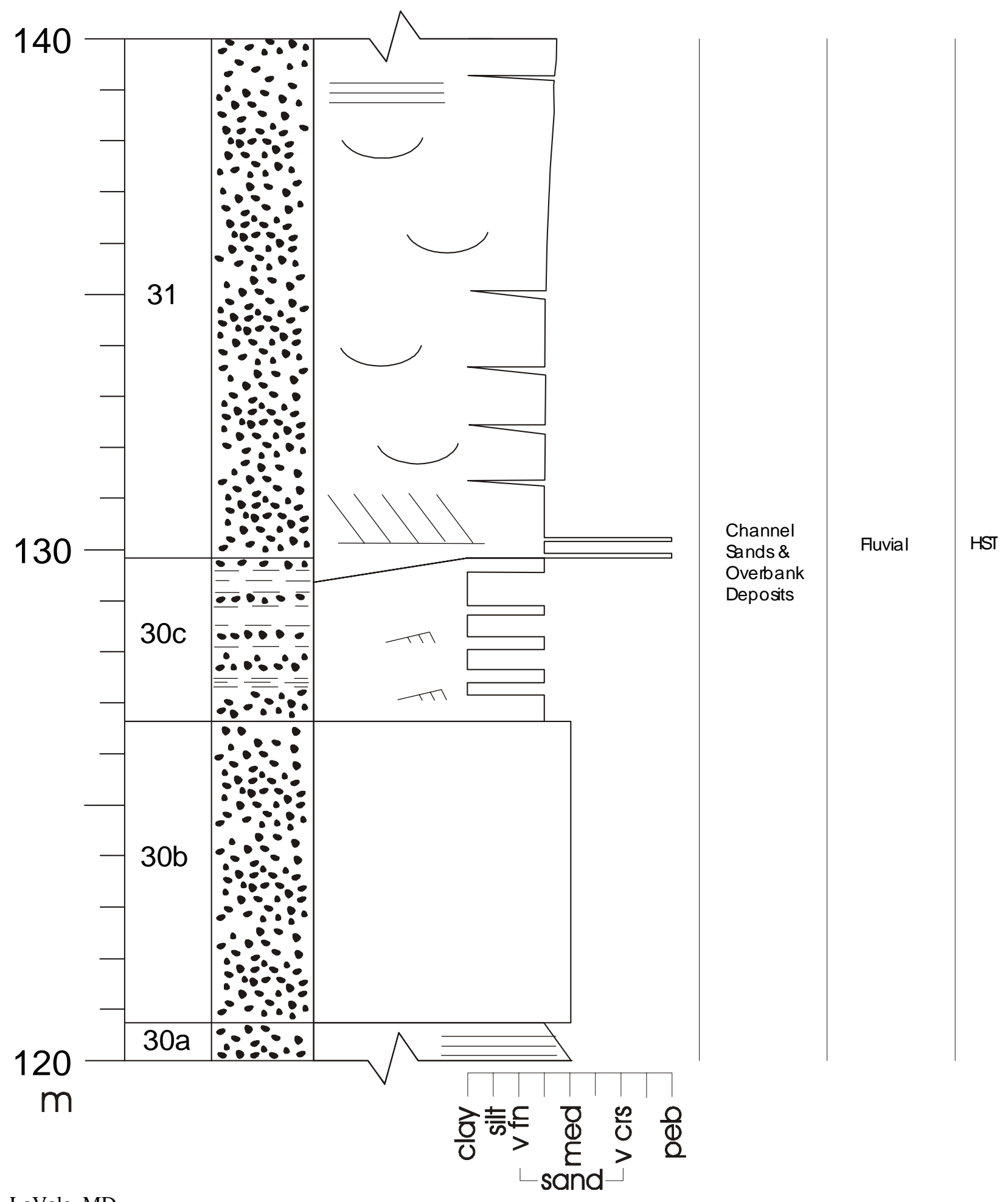

LaVale, MD 


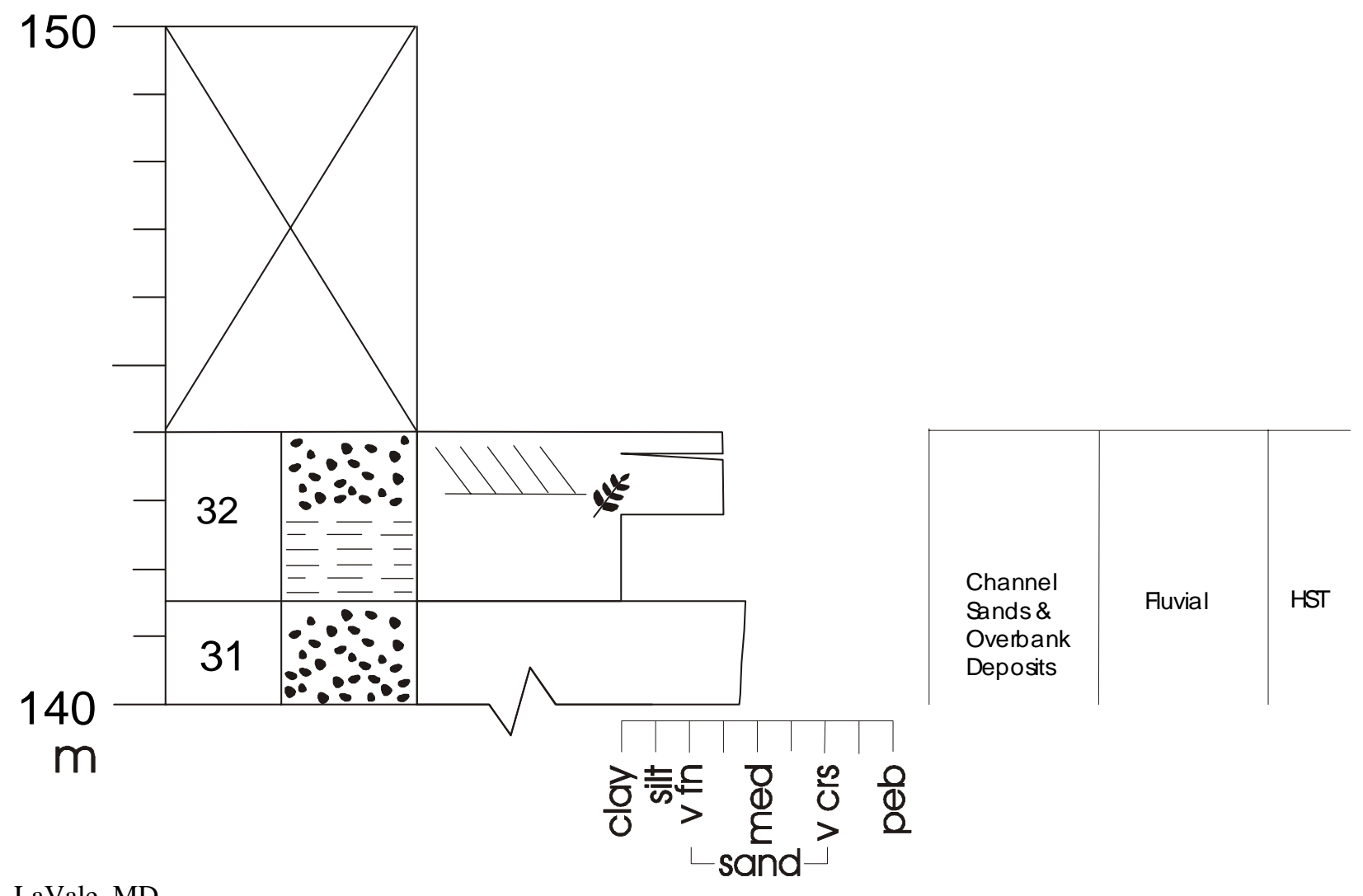

LaVale, MD 


\section{SIDELING HILL MARYLAND \\ OUTCROP}


Sideling Hill Outcrop

Location: I-68 East, Hancock MD

Date: Saturday September 7, 2002

UNIT 1: Thickness - $28.3 \mathrm{~m}(92.85 \mathrm{ft})$

Rockname - Diamictite

Rock color - Light tan to green-brown (fresh) rusty-gray (weathered)

Bedding - No apparent bedding

Sed. Structures - No sedimentary structures observed

Trace $\&$ body fossils - No trace or body fossils observed

Comments - Lower half has a sandy matrix. Abundant plant trash present. Lower portion

topped by platy red shale. Concealed basal contact.

UNIT 2: Thickness - $18.0 \mathrm{~m}(59.06 \mathrm{ft})$

Rockname - Coarse-grained (base) to medium-grained (top) SANDSTONE containing quartz pebbles near base

Rock color - Light gray (fresh) red-brown to tan-orange (weathered)

Bedding - Medium to thickly bedded. Bedding is fractured and has a blocky texture. Fractures appear to be along bedding planes. Weathering is severe on outcrop.

Sed. Structures - Horizontal stratification, to trough cross-bedding, to low angle planar crossstratification

Trace \& body fossils - No trace or body fossils observed

Comments - Grain size change occurs with color break on outcrop from rusty-brown blocky

texture to gray platy texture. Sandstone appears clean and well sorted. Gradational basal contact.

UNIT 3: Thickness - $10.5 \mathrm{~m}(34.45 \mathrm{ft})$

Rockname - SILTSTONE w/interbedded SHALE. $1 \mathrm{~m}$ thick fine-grained SANDSTONE lense Rock color - Shale is black carbonaceous. Siltstone is dark gray. Sandstone is gray to greengray.

Bedding - Shale is fissile and platty becoming more silty toward the top but remaining fissile. Siltstone is laminated and internally massive. Within siltstone is a $1 \mathrm{~m}$ thick fine-grained sandstone appearing lenticular in section. Unit contains carbonaceous lenses of shale, almost coaly (10-15 cm thick, about $2.5 \mathrm{~cm}$ from the top).

Sed. Structures - No apparent structures in siltstone. Coaly shale lenses contain compaction ripples.

Trace \& body fossils - No trace or body fossils observed

Comments - Top of unit contains scattered pyrite nodules. Gradational basal contact.

UNIT 4: Thickness - $8.4 \mathrm{~m}(27.56 \mathrm{ft})$

Rockname - SHALE

Rock color - Black

Bedding - Fissile and splintery. Becomes silty and more massive at the top

Sed. Structures - No sedimentary structures observed

Trace \& body fossils - No trace or body fossils observed 
Comments - Unit contains few thin siltstone lenses. Outcrop is very splintery at base and grades out toward the top. Talus is all splinters. Becomes less fissile toward the top. Sharp basal

contact.

UNIT 5: Thickness - $0.4 \mathrm{~m}(1.31 \mathrm{ft})$

Rockname - Very fine-grained SANDSTONE

Rock color - Light gray

Bedding - Bedding is massive and unit contains thin shale lenses

Sed. Structures - No sedimentary structures observed

Trace \& body fossils - No trace or body fossils observed

Comments - Sharp basal contact

UNIT 6: Thickness - $1.4 \mathrm{~m}(4.59 \mathrm{ft})$

Rockname - SHALE with a very fine-grained SANDSTONE lens

Rock color - Shale is gray, sandstone is light gray

Bedding - Shale weathers blocky to splintery and lacks fissility. Sandstone is about $10 \mathrm{~cm}$ thick and resembles UNIT 5

Sed. Structures - No sedimentary structures observed

Trace \& body fossils - No trace or body fossils observed

Comments - Sharp basal contact

UNIT 7: Thickness - $0.15 \mathrm{~m}(0.49 \mathrm{ft})$

Rockname - Fine-grained SANDSTONE

Rock color - Gray

Bedding - Laminated but similar to UNIT 5

Sed. Structures - No sedimentary structures observed

Trace \& body fossils - No trace or body fossils observed

Comments - Very similar to UNIT 5. Sharp basal contact.

UNIT 8: Thickness - $2.4 \mathrm{~m}(7.87 \mathrm{ft})$

Rockname - SHALE

Rock color - Dark gray

Bedding - Highly compacted, lacks fissility, platy to splintery weathering profile.

Sed. Structures - Relic laminations

Trace \& body fossils - No trace or body fossils observed

Comments - Scattered organic debris, possibly plant trash. Sharp basal contact.

UNIT 9: Thickness - $0.5 \mathrm{~m}(1.64 \mathrm{ft})$

Rockname - Fine-grained SANDSTONE

Rock color - Light gray

Bedding - Bedding is massive and unit contains thin shale lenses

Sed. Structures - No sedimentary structures observed

Trace \& body fossils - No trace or body fossils observed

Comments - Sharp basal contact

UNIT 10: Thickness - $2.5 \mathrm{~m}(8.20 \mathrm{ft})$ 
Rockname - SILTSTONE

Rock color - Light to medium gray

Bedding - Laminated

Sed. Structures - No sedimentary structures observed

Trace \& body fossils - No trace or body fossils observed

Comments - Scattered plant trash throughout. Top of unit contains a $20 \mathrm{~cm}$ lens of shale. Sharp basal contact.

UNIT 11: Thickness - $3.0 \mathrm{~m}(9.84 \mathrm{ft})$ C.U.S

Rockname - SHALE and fine-grained SANDSTONE

Rock color - Carbonaceous shale (basal $30 \mathrm{~cm}$ ). Sandstone is medium gray

Bedding - Shale bedding is deformed from soft sediment deformation. Somewhat fissile and platy. Shale becomes silty, fissile to laminated toward top. Bedding more defined at top and sandstone is medium bedded (70 cm thick) and laminated.

Sed. Structures - No sedimentary structures observed

Trace \& body fossils - No trace or body fossils observed

Comments - Sharp basal contact

UNIT 12: Thickness - $1.0 \mathrm{~m}$ (3.28 ft) C.U.S

Rockname - SHALE and SILTSTONE

Rock color - Dark gray

Bedding - Shale is fissile and laminated, carbonaceous toward base. Becomes more thin to medium bedded at top of unit. Also laminated at top. Shale grades into siltstone at top of unit, remains carbonaceous.

Sed. Structures - No sedimentary structures observed

Trace \& body fossils - No trace or body fossils observed

Comments - Top of unit contains some plant trash. Sharp basal contact.

UNIT 13: Thickness - $4.6 \mathrm{~m}$ (15.09 ft)

Rockname - Silty SHALE to very fine-grained SANDSTONE

Rock color - Dark gray

Bedding - Shale is fissile and somewhat carbonaceous at base, the rest of unit is massive. Above base is a shaly, very fine-grain sandy siltstone.

Sed. Structures - No sedimentary structures observed

Trace \& body fossils - No trace or body fossils observed

Comments - Silt to very fine-grain sandstone is places but very discontinuous. Gradational basal contact.

UNIT 14: Thickness - 1.1m (3.61 ft)

Rockname - SHALE and discontinuous fine-grain micaceous SANDSTONE

Rock color - Shale is dark gray. Sandstone is green-gray.

Bedding - Basal shale is platy to fissile and over pressured. Sandstone is medium bedded and internally massive. Sandstone grades in and out of shale throughout unit.

Sed. Structures - No sedimentary structures observed

Trace \& body fossils - No trace or body fossils observed

Comments - Gradational basal contact 
UNIT 15: Thickness $-4.5 \mathrm{~m}(14.76 \mathrm{ft})$

Rockname - SHALE interbedded fine-grained SANDSTONE

Rock color - Shale is dark gray. Sandstone is green-gray

Bedding - Shale is more fissile to platy than UNIT 14 with massive zones. Unit becomes more silty at top and more platty. Sandstone grades much like UNIT 14.

Sed. Structures - No sedimentary structures observed

Trace \& body fossils - No trace or body fossils observed

Comments - Gradational basal contact

UNIT 16: Thickness - $1.3 \mathrm{~m}(4.27 \mathrm{ft})$

Rockname - MUDSTONE and SILTSTONE

Rock color - Mudstone is red-brown. Siltstone is dark gray.

Bedding - Mudstone is deeply weathered. Siltstone is $10-15 \mathrm{~cm}$ thick in middle of unit and weathers hackly.

Sed. Structures - No sedimentary structures observed

Trace \& body fossils - No trace or body fossils observed

Comments - Unit is a possible paleosol. Sharp basal contact based on weathering profile.

UNIT 17: Thickness $-8.9 \mathrm{~m}(29.20 \mathrm{ft})$

Rockname - Coarse- to very fine-grained (fining up) SANDSTONE

Rock color - Light tan to dark gray (fresh)

Bedding - Base is very thick to massive bedding containing shale partings and clasts $(1-5 \mathrm{~cm})$. Upper half the bedding is blocky to hackly.

Sed. Structures - Middle of unit contains cross-beds to planar laminae. Upper portion is planar laminated.

Trace \& body fossils - No trace or body fossils observed

Comments - Base of unit contains coarse sand, mostly quartz grains with some lithics. Upper

half is very fine-grain sandstone to siltstone. Upper $3 \mathrm{~m}$ is clearly more silty on outcrop. Minor channels of UNIT 17 scour about $1 \mathrm{~m}$ into UNIT 16. Sharp basal contact.

UNIT 18: Thickness $-0.9 \mathrm{~m}$ (2.95 ft)

Rockname - MUDSTONE

Rock color - Dark gray (fresh). Color appears similar to graphite, mottled dark green-gray.

Bedding - Weathers hackly

Sed. Structures - No sedimentary structures observed

Trace \& body fossils - No trace or body fossils observed

Comments - Unit contains pedigenic slickensides and iron nodules. Sharp basal contact based on recessed weathering profile.

UNIT 19: Thickness - $0.7 \mathrm{~m}(2.30 \mathrm{ft})$

Rockname - SHALE

Rock color - Dark gray and vitreous, almost coaly

Bedding - Medium bedded at base. Loose bedding toward top of unit. Fissile but not laminated.

Weathers hackly toward top.

Sed. Structures - No sedimentary structures observed

Trace \& body fossils - No trace or body fossils observed 
Comments - Unit contains abundant plant trash, organic rich. Sharp basal profile based on weathering profile.

UNIT 20: Thickness - 2.35 m (7.71 ft) C.U.S

Rockname - SHALE, SILTSTONE, and very fine-grained SANDSTONE

Rock color - Dark gray overall

Bedding - Basal shale is laminated, splintery weathering. Loose laminations toward top and becomes more hackly. Sandstone at top is medium bedded and massive.

Sed. Structures - No sedimentary structures observed

Trace \& body fossils - No trace or body fossils observed

Comments - Grain size grades up through unit. Top bedding surface may contain bioturbation.

Sharp basal contact.

UNIT 21: Thickness - 0.9 m (2.95 ft)

Rockname - MUDSTONE

Rock color- Dark gray but becomes more red at top

Bedding - Hackly weathered texture with pedigenic slickensides.

Sed. Structures - No sedimentary structures observed

Trace \& body fossils - No trace or body fossils observed

Comments - Unit is identical to UNIT 18. Sharp basal contact based on weathering profile.

UNIT 22: Thickness - $1.1 \mathrm{~m}(3.61 \mathrm{ft})$

Rockname - SHALE grading into very fine-grained SANDSTONE

Rock color - Dark gray shale, gray sandstone

Bedding - Shale is laminated but not fissile and mottled at base. Shale gradually grades into

very fine sandstone with massive bedding.

Sed. Structures - No sedimentary structures observed

Trace \& body fossils - No trace or body fossils observed

Comments - Gradational basal contact

UNIT 23: Thickness - $2.5 \mathrm{~m}(8.20 \mathrm{ft})$

Rockname - MUDSTONE

Rock color - Dark gray (fresh). Color appears similar to graphite, mottled dark green-gray.

Bedding - Weathers hackly

Sed. Structures - No sedimentary structures observed

Trace \& body fossils - No trace or body fossils observed

Comments - Unit contains pedigenic slickensides and iron nodules. Sharp basal contact based on recessed weathering profile.

UNIT 24: Thickness - $0.10 \mathrm{~m}(0.33 \mathrm{ft})$

Rockname - SHALE

Rock color - Black, carbonaceous, vitreous, and organic rich to coaly

Bedding - Fissile

Sed. Structure - No sedimentary structures observed

Trace \& body fossils - No trace or body fossils observed

Comments - Unit contains scattered plant trash. Possible flooding surface. 
UNIT 25: Thickness - $2.4 \mathrm{~m}(7.87 \mathrm{ft})$

Rockname - Medium- to very fine-grained SANDSTONE with interbedded SILTSTONE lenses Rockcolor - Sandstone is green-gray

Bedding - Base of unit is medium to very thickly bedded and becomes massive toward top with a hackly weathered profile. Siltstone beds are 6-7 cm thick or less and random throughout unit. Sed. Structures - No sedimentary structures observed

Trace \& body fossils - No trace or body fossils observed

Comments - Sandstone becomes more silty at top of unit. Sandstone bedding thins laterally. Sharp basal contact.

UNIT 26: Thickness - $1.7 \mathrm{~m}(5.58 \mathrm{ft})$

Rockname - MUDSTONE with $6 \mathrm{~cm}$ thick very fine-grained SANDSTONE lenses Rock color - Dark gray (fresh). Color appears similar to graphite, mottled dark green-gray. Bedding - Weathers hackly

Sed. Structures - No sedimentary structures observed

Trace \& body fossils - No trace or body fossils observed

Comments - Gradational basal contact

UNIT 27: Thickness - $9.5 \mathrm{~m}$ (31.17) ft

Rockname - Medium- to very fine-grained SANDSTONE interbedded SHALE

Rock color - Shale is dark gray to green-tan-gray. Sandstone is green-gray

Bedding - Shale are compacted and weather hackly. Shale grades in and out of hackly and massive. Sandstone is medium to thickly bedded. Top of unit is capped by a medium-thickly bedded very fine-grain sandstone. Channel scouring is prevalent toward the top of unit.

Sed. Structures - Sandstone is planar laminated at top

Trace \& body fossils - No trace or body fossils observed

Comments - Shale content increases upward. Sandstone is medium-grain at base and decreases to very fine-grain at top. Sharp basal contact.

UNIT 28: Thickness - $1.6 \mathrm{~m}(5.25 \mathrm{ft})$

Rockname - MUDSTONE

Rock color - Dark gray (fresh). Color appears similar to graphite, mottled dark green-gray.

Bedding - Weathers hackly

Sed. Structures - No sedimentary structures observed

Trace \& body fossils - No trace or body fossils observed

Comments - Unit contains pedigenic slickensides and iron nodules. Sharp basal contact based on recessed weathering profile.

UNIT 29: Thickness - $0.3 \mathrm{~m}(0.98 \mathrm{ft})$

Rockname - SHALE.

Rock color - Black, vitreous, carbonaceous with iron stains.

Bedding - Fissile

Sed. Structures - No sedimentary structures observed

Trace \& body fossils - No trace or body fossils observed 
Comments - Possible flooding surface. Sharp basal contact.

UNIT 30: Thickness $-0.7 \mathrm{~m}(2.30 \mathrm{ft})$

Rockname - SHALE and fine-grained SANDSTONE

Rock color - Dark gray to black. Unit contains carbon films on laminated surfaces.

Bedding - Basal shale pinches and swells, rest of unit is laminated and fissile. Sandstone is

thinly bedded and lenticular. Sandstone also pinches and swells.

Sed. Structures - No sedimentary structures observed

Trace \& body fossils - No trace or body fossils observed

Comments - Sandstone is completely pyritized. Basal shale has abundant plant trash. This unit is very different from what is normally observed. Upper $5 \mathrm{~cm}$ becomes carby and vitreous.

Sharp basal contact.

UNIT 31: Thickness - $2.9 \mathrm{~m}(9.51 \mathrm{ft})$

Rockname - MUDSTONE

Rock color - Dark gray (fresh). Color appears similar to graphite, mottled dark green-gray.

Vitreous luster.

Bedding - Weathers hackly to splintery

Sed. Structures - No sedimentary structures observed

Trace \& body fossils - No trace or body fossils observed

Comments - Unit contains pedigenic slickensides and iron nodules. Sharp basal contact based on recessed weathering profile.

UNIT 32: Thickness $-0.7 \mathrm{~m}(2.30 \mathrm{ft})$

Rockname - MUDSTONE and SHALE

Rock color - Mudstone similar to UNIT 31. Shale is green-gray (fresh) rusty brown (weathered).

Bedding - Weathers hackly and somewhat fissile but not laminated

Sed. Structures - No sedimentary structures observed

Trace \& body fossils - No trace or body fossils observed

Comments - Gradational basal contact

UNIT 33: Thickness - $2.0 \mathrm{~m}(6.56 \mathrm{ft})$

Rockname - SHALE to very fine-grained SANDSTONE at base. Medium-grain SANDSTONE at top (coarsening up)

Rock color - Light gray to tan

Bedding - Shale and very fine-grain sandstone at base grades into medium-grain sandstone half way up unit. Shale is interbedded in sandstone and laminated. Bedding is thin at base and medium to thick and lenticular toward the top.

Sed. Structures - Sandstone is rippled at top

Trace \& body fossils - No trace or body fossils observed

Comments - Sharp basal contact

UNIT 34: Thickness - $0.5 \mathrm{~m}$ (1.64 ft)

Rockname - Very fine-grained SANDSTONE with SHALE intervals

Rock color - Green-gray 
Bedding - Sandstone is massive

Sed. Structures - No sedimentary structures observed

Trace \& body fossils - No trace or body fossils observed

Comments - Gradational undulatory basal contact

UNIT 35: Thickness - $2.3 \mathrm{~m}(7.55 \mathrm{ft})$

Rockname - MUDSTONE with confined lenses of SILTSTONE

Rock color - Dark gray (fresh). Color appears similar to graphite, mottled dark green-gray

Bedding - Weathers hackly

Sed. Structures - No sedimentary structures observed

Trace \& body fossils - No trace or body fossils observed

Comments - Unit contains pedigenic slickensides and iron nodules. Sharp basal contact based

on recessed weathering profile.

UNIT 36: Thickness - 1.7 m (5.58 ft)

Rockname - Very fine- to fine-grained SANDSTONE

Rock color - Green-gray

Bedding - Lenticular bedding and massive

Sed. Structures - No sedimentary structures observed

Trace \& body fossils - No trace or body fossils observed

Comments - Unit contains shale partings. Sharp basal contact.

UNIT 37: Thickness - $0.60 \mathrm{~m}(1.97 \mathrm{ft})$

Rockname - MUDSTONE

Rock color - Dark gray (fresh). Color appears similar to graphite, mottled dark green-gray

Bedding - Weathers hackly

Sed. Structures - No sedimentary structures observed

Trace \& body fossils - No trace or body fossils observed

Comments - Unit contains pedigenic slickensides and iron nodules. Sharp basal contact based on recessed weathering profile. Very top of unit contains a 1-3 cm coaly carby shale layer.

UNIT 38: Thickness - $11.3 \mathrm{~m}(37.07 \mathrm{ft})$

Rockname - Fine- to very fine-grained (fining up) SANDSTONE interbedded SHALE and MUDSTONE

Rock color - Unit has an overall reddish color. Shale and mudstone are red, mottled, and contain pedigenic slickensides

Bedding - Sandstone is fine-grain at base and grades into very fine-grain at top, almost silty. Bedding is massive. Overall appearance is shale content increases upward, grain size decreases upward (fn - vfn- silt).

Sed. Structures - Faint cross-bedding in basal sandstone.

Trace \& body fossils - No trace or body fossils observed

Comments - Sharp basal contact

UNIT 39: Thickness - 30 m (98.43 ft)

Rockname - Medium- to very fine-grained (fining up) SANDSTONE

Rock color - Light gray to olive-gray toward top (fresh), rusty to orange brown (weathered). 
Bedding - Blocky and fractured weathered texture. Bedding is massive in places and alternates from thin to very thick toward the top. Bedding is lost toward top.

Sed. Structures - Inclined heterolithic stratification. Unit contains:

1) conglomeratic lenses throughout.

2) scoured bedding surfaces.

3) dominant sed. Structure is planar stratification with minor cross-beds (low angle forests).

4) mud plugs or discontinuous lenses thinly bedded.

5) Sandstone beds are lenticular.

Trace \& body fossils - No trace or body fossils observed

Comments - Upper 3 m grades into silty shale. Green-gray (fresh), brown with vitreous stains (weathered). Weathers pencil cleavage. Massive bedding. Lacks fissility. Sharp basal contact, possibly erosional.

UNIT 40: Thickness - $2.0 \mathrm{~m}(6.56 \mathrm{ft})$

Rockname - MUDSTONE

Rock color - Red (fresh), black to red-brown (weathered). Deeply weathered

Bedding - Weathers hackly to crumbly

Sed. Structures - No sedimentary structures observed

Trace \& body fossils - No trace or body fossils observed

Comments - Ferrous oxide, ghertite, and manganese. Sharp basal contact based on weathering profile.

UNIT 41: Thickness - $2.3 \mathrm{~m}$ (ft)

Rock name - Fine-grained SANDSTONE and interbedded MUDSTONE

Rock color - Mudstone is red (fresh), black to red-brown (weathered). Sandstone is tan-gray

Bedding - Sandstone is medium bedded, shale has a blocky to hackly weathering profile.

Sed. Structures - Sandstone is massive

Trace \& body fossils - No trace or body fossils observed

Comments - Base of unit marked by a $3-5 \mathrm{~cm}$ continuous dark colored platy shale with a pearly luster, almost greasy feel, thickness varies laterally. Majority of unit contains discontinuous mud lenses. Sharp scour-base contact.

UNIT 42: Thickness - $1.1 \mathrm{~m}$ (ft)

Rock name - MUDSTONE

Rock color - Red (fresh), black to red-brown (weathered)

Bedding - Hackly to crumbly weathering profile

Sed. Structures - No sedimentary structures observed

Trace \& body fossils - No trace or body fossils observed

Comments - Unit very similar to Unit 40. Thickness changes laterally due to erosion by over lying unit.

UNIT 43: Thickness - $10.0 \mathrm{~m}$ (ft)

Rock name - Coarse- to medium-grained SANDSTONE

Rock color - Light gray to green-gray (fresh), tan to orange-brown (weathered)

Bedding - Medium to thinly bedded at base becoming more thickly bedded at top. 
Sed. Structures - Cross-bedding with low angle foresets and minor planar stratification.

Sandstone at top of unit contains alternating planar to cross stratification.

Trace \& body fossils - No trace or body fossils observed

Comments - Unit contains abundant shale clasts and conglomeratic lenses with granular to

pebble size clasts near the base. Sharp scour base contact.

UNIT 44: Thickness - $11.5 \mathrm{~m}$ (ft)

Rock name - SILTSTONE with interbedded very fine-grained SANDSTONE

Rock color - Olive green at base grading into red-gray at top (fresh), rusty brown (weathered).

Bedding - Bedding lost due to weathering

Sed. Structures - Relic laminations near top

Trace \& body fossils - No trace or body fossils observed

Comments - Sharp basal contact

UNIT 45: Thickness - $6.0 \mathrm{~m}(\mathrm{ft})$

Rock name - MUDSTONE

Rock color - Rusty-red at base; gray-white at top (fresh), rusty brown (weathered)

Bedding - hackly

Sed. Structures - No sedimentary structures observed

Trace \& body fossils - No trace or body fossils observed

Comments - Upper .50 m contains abundant root casts. Color change from light gray to dark gray at very top. Unit is possible paleosol. Thickness varies due to scour by overlying Sandstone.

Gradational basal contact.

UNIT 46: Thickness - $1.4 \mathrm{~m}(\mathrm{ft})$

Rock name - Coarse-grained SANDSTONE and CONGLOMERATE

Rock color - light gray

Bedding - Lenticular and thickness changes

Sed. Structures - Cross to planar stratification. Cross-beds contain random quartz pebbles less than $1.0 \mathrm{~cm}$ in diameter

Trace and body fossils - No trace or body fossils observed

Comments - Conglomeratic layers contain rip up clasts. Sharp erosional basal contact.

\section{Lower $17 \mathrm{~m}$ at Sideling Hill}

Section measured along the southwest side of Route 40

Summarized from Suter (1991)

UNIT DESCRIPTIONS

UNIT $1-(1.10 \mathrm{~m})$

Fissile black shale with pyrite nodules and plant debris.

UNIT $2-(0.72 \mathrm{~m})$

Green-gray, fine-grained sandstone with plant debris and muscovite flakes, weathering orange. The unit has a channel shape morphology at the base with red pebbles and very coarse sand and internally laminated. 
UNIT $3-(1.33 \mathrm{~m})$

Unit completely covered

UNIT $4-(2.39 \mathrm{~m})$

Medium- to coarse-grained sandstone with cross-laminae and plant debris. Sandstone body has a channel shape. Grain size changes in the middle from medium to coarse-grained sand. Black siltstone clasts were observed in the basal contact. The top of the unit has a planar crossbedded layer with cross-beds dipping in the opposite direction as those beds in the rest of the unit. Trough cross-bedding was also observed in the upper part.

UNIT $5-(1.39 \mathrm{~m})$

Coarse-grained sandstone in a channel shape with trough cross-bedding. Plant debris is aligned at the top of the unit. Siltstone and shale clasts were also observed at the top.

UNIT $6-(0.98 \mathrm{~m})$

Coarse-grained sandstone in a channel shape with trough cross-bedding.

UNIT $7-(0.81 \mathrm{~m})$

Coarse-grained sandstone in a channel shape with trough cross-bedding.

UNIT $8-(3.10 \mathrm{~m})$

Unit contains some shale, but mostly covered.

UNIT 9 - (0-1.46 m)

Fine-grained sandstone to siltstone becoming extremely soft upon weathering. Unit has a channel shape that pinches out to $0 \mathrm{~mm}$ within the width of the outcrop. Sandstone contains mica flakes and weathers orange.

UNIT $10-(1.54 \mathrm{~m})$

Mostly covered, but does contain a gray-black, laminated silty shale with plant fragments.

UNIT $11-(1.78 \mathrm{~m})$

Medium-grained sandstone, internally laminated containing mica flakes and plant debris. The sandstone weathers orange. The sandstone has a scour base and contains shale clasts, quartz pebbles, and abundant plant debris.

UNIT $12-(0.09 \mathrm{~m})$

Laminated sandy shale. This unit may be the basal part of the overlying diamictite. 


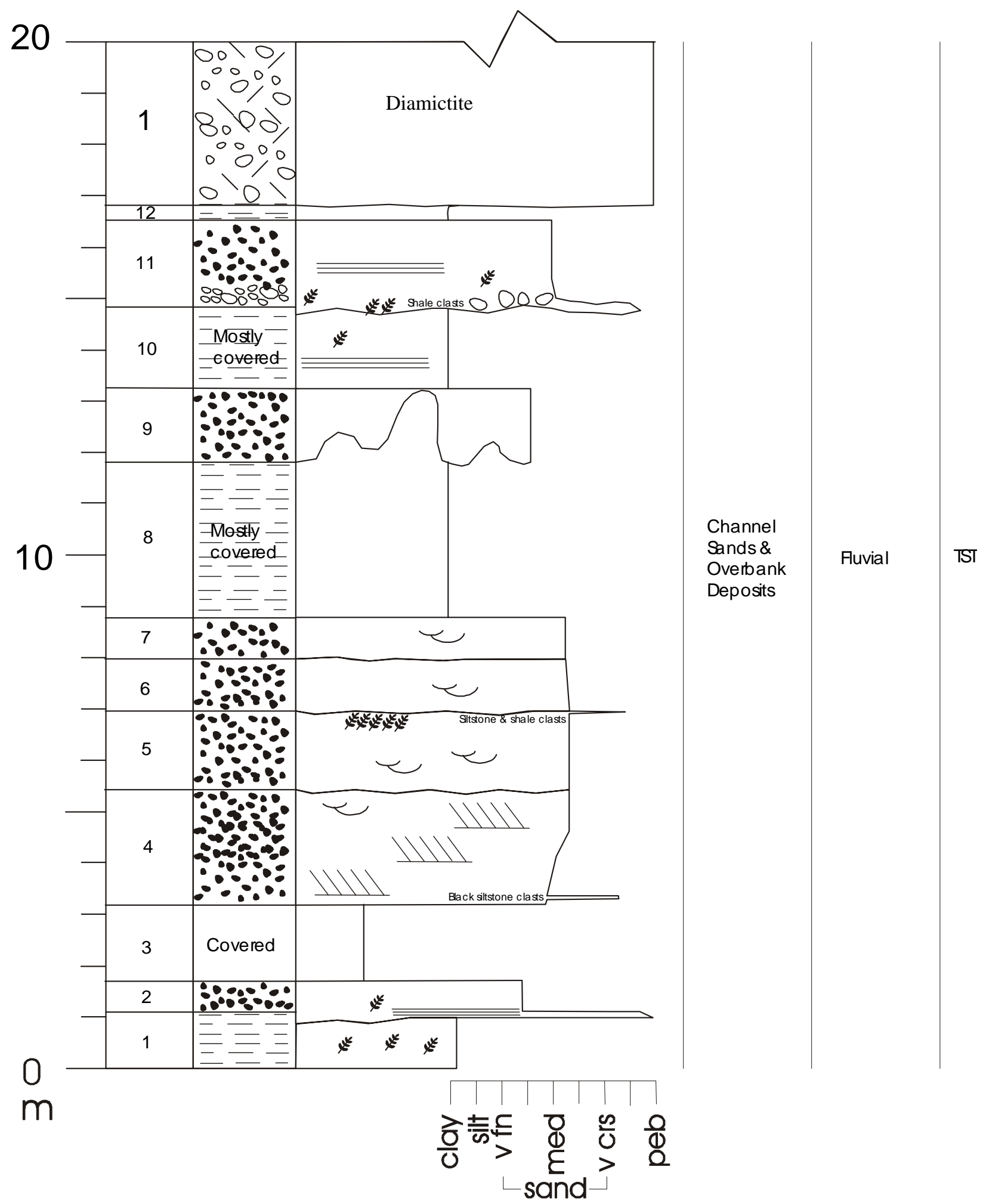

Sideling Hill, MD 


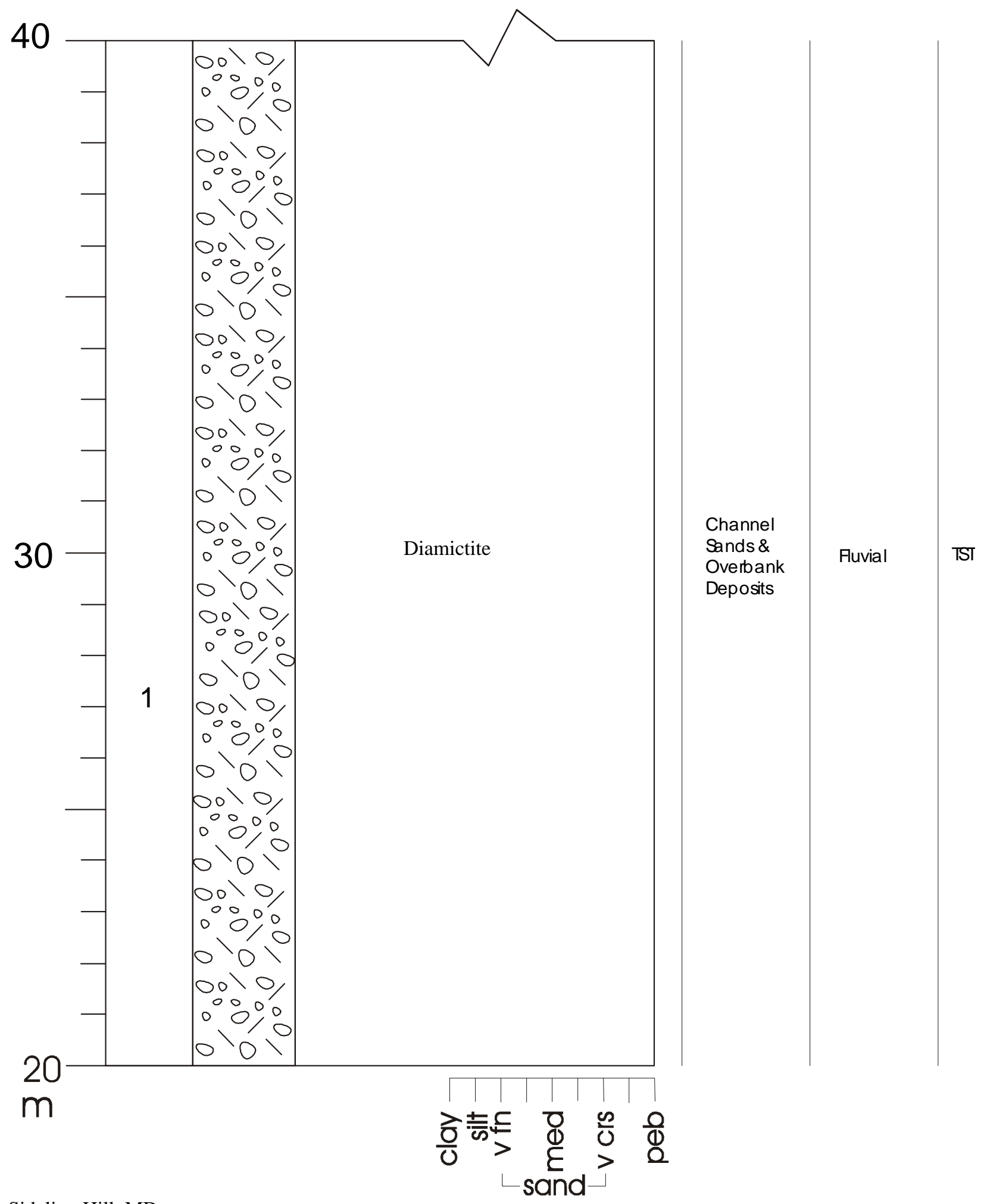

Sideling Hill, MD 


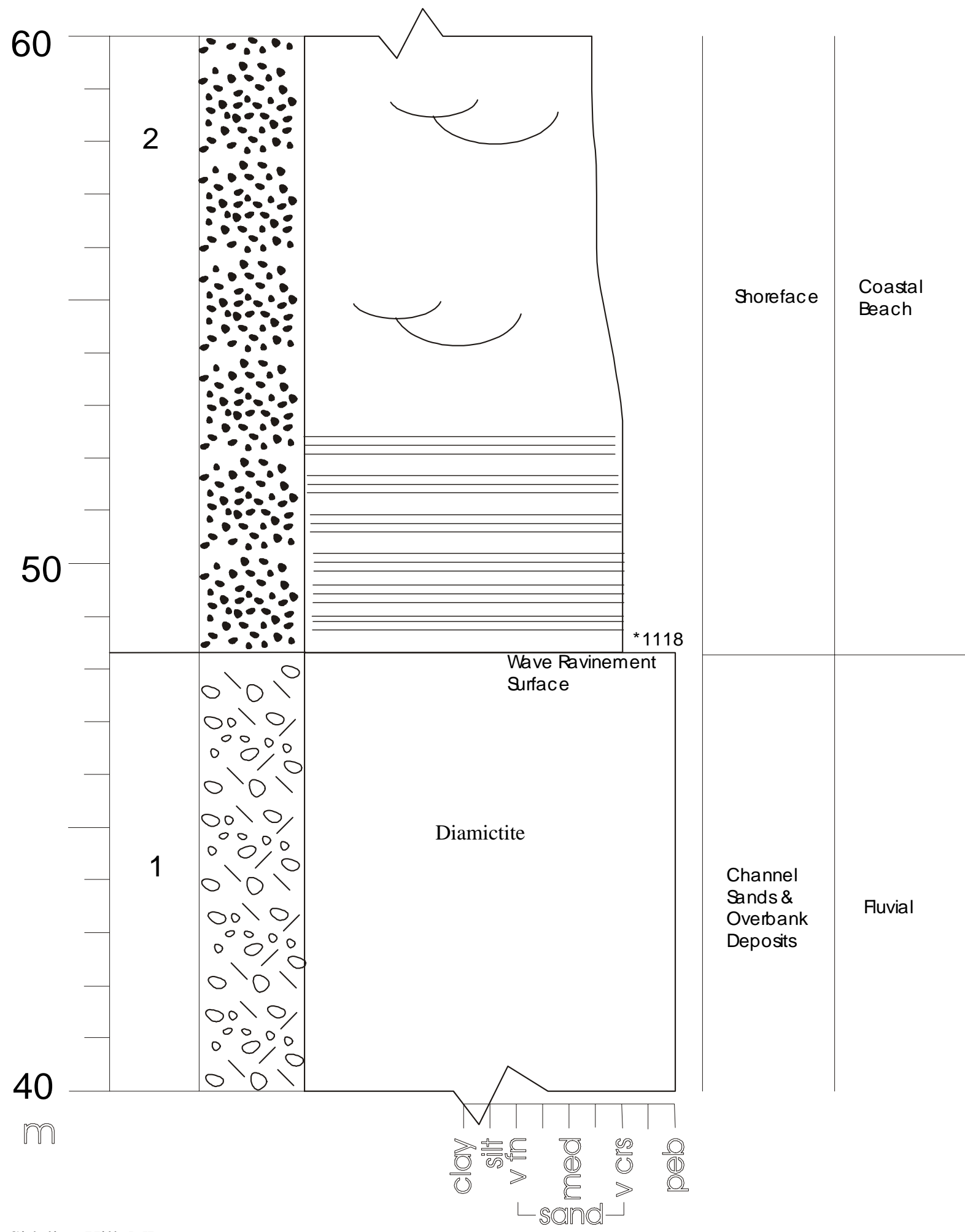

TST

Sideling Hill, MD 


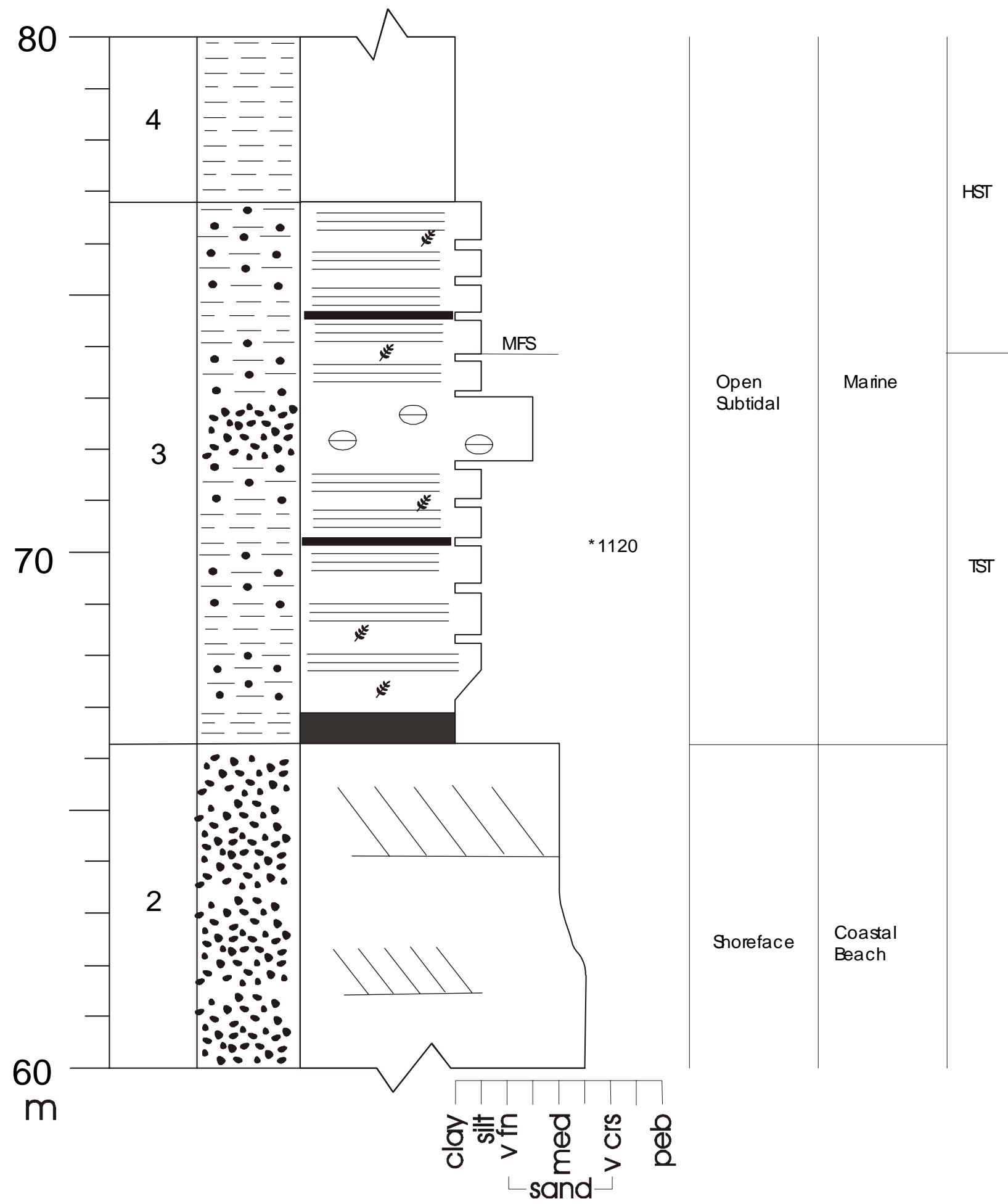

Sideling Hill, MD 


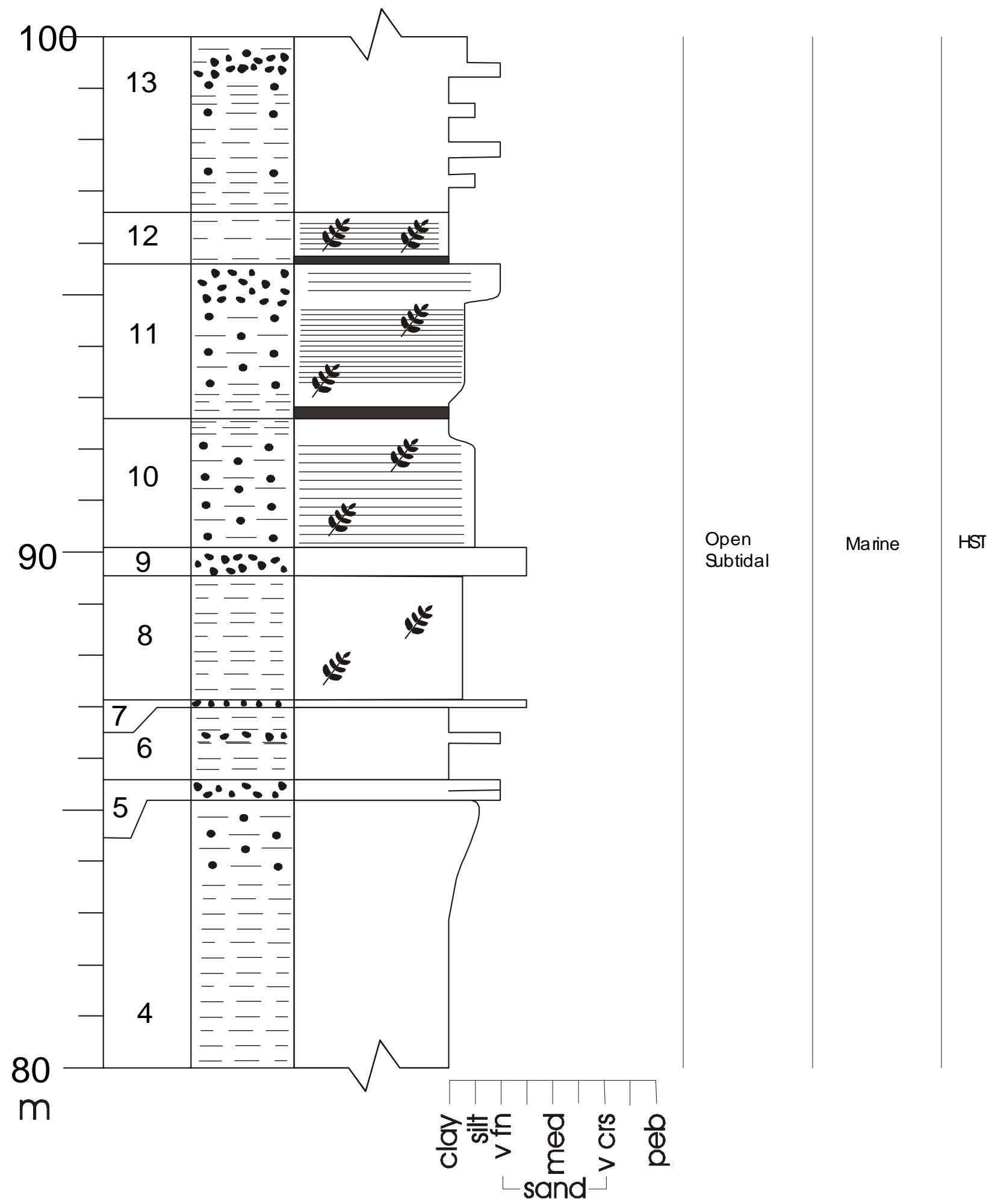

Sideling Hill, MD 


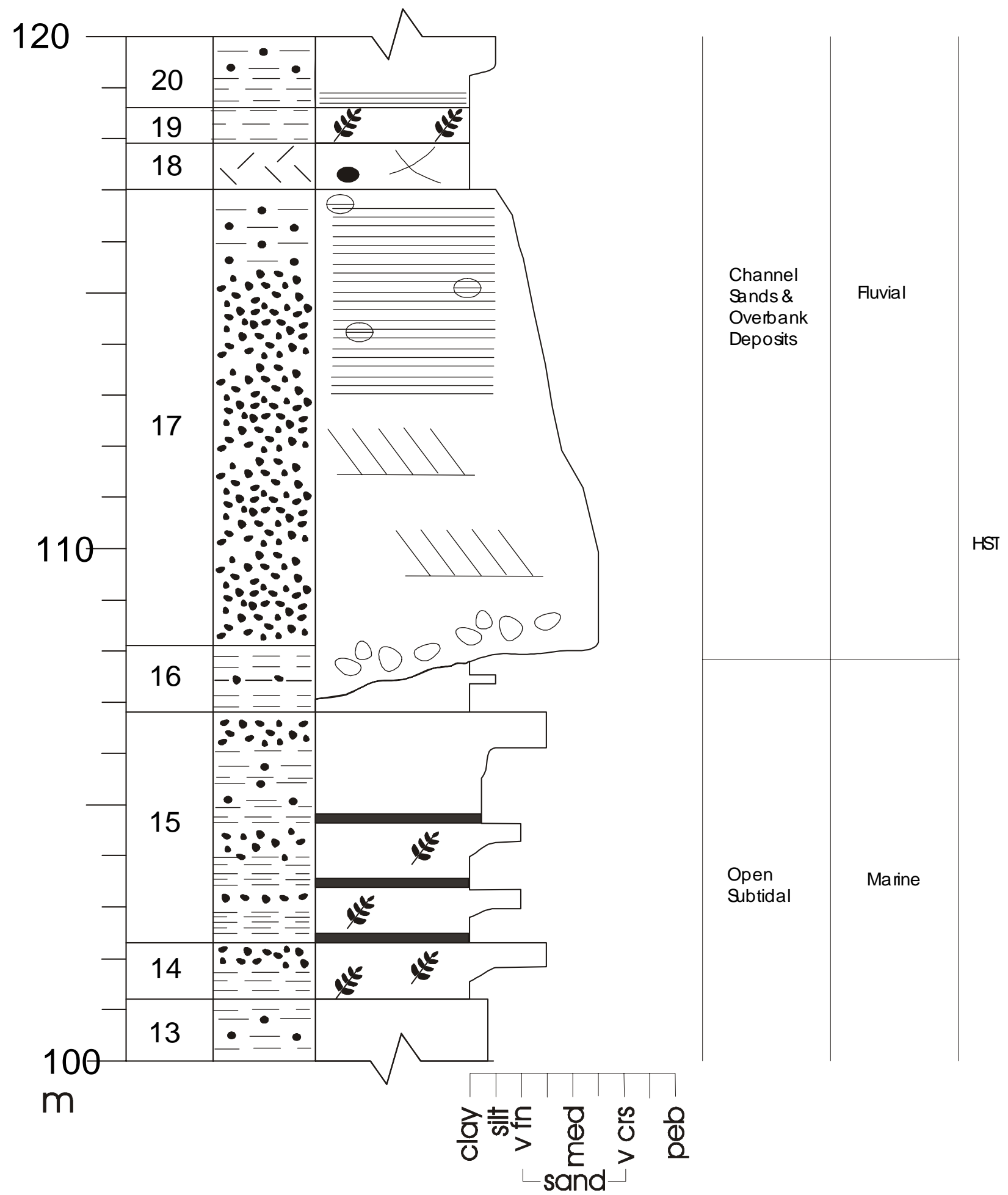

Sideling Hill, MD 


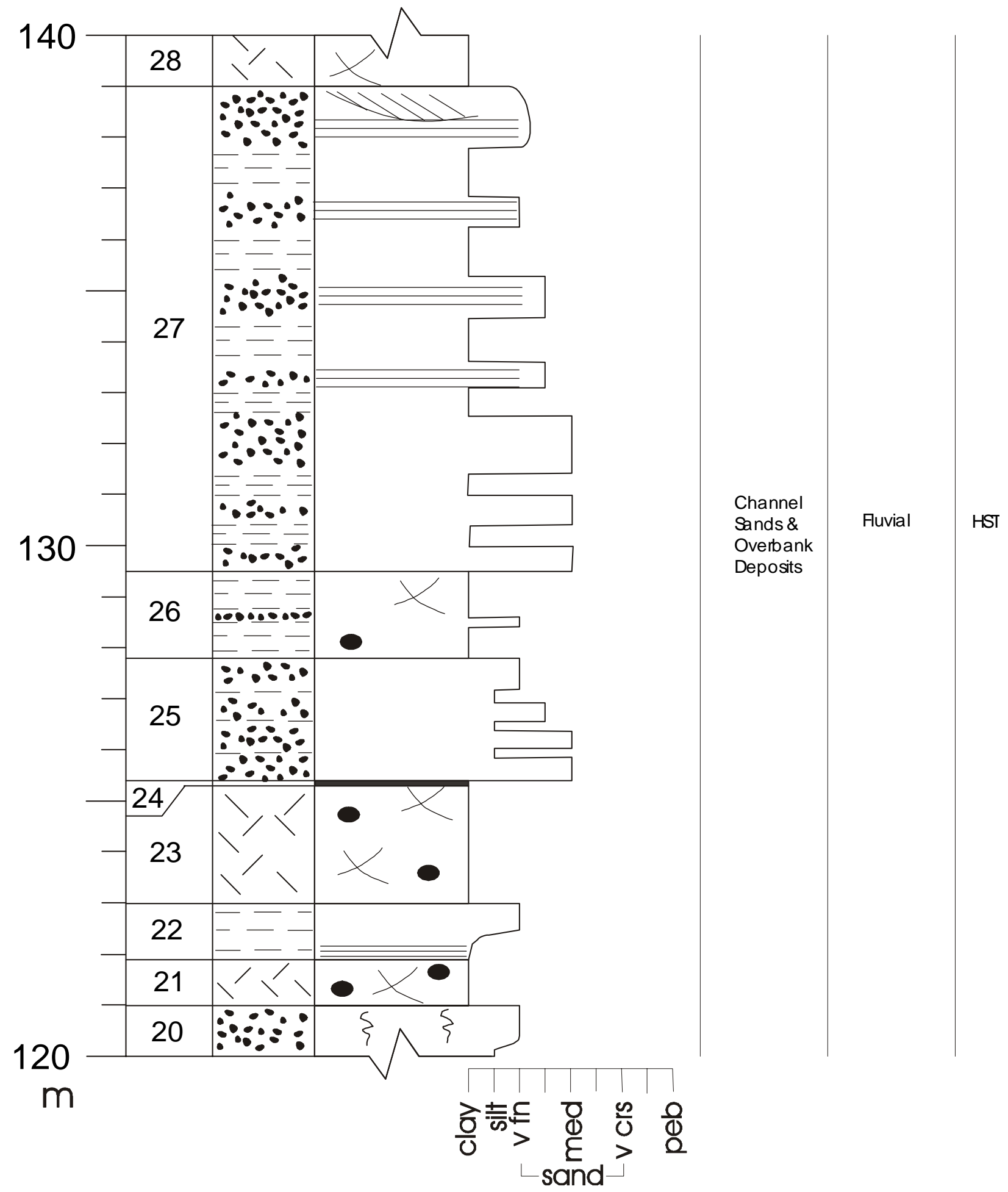

Sideling Hill, MD 


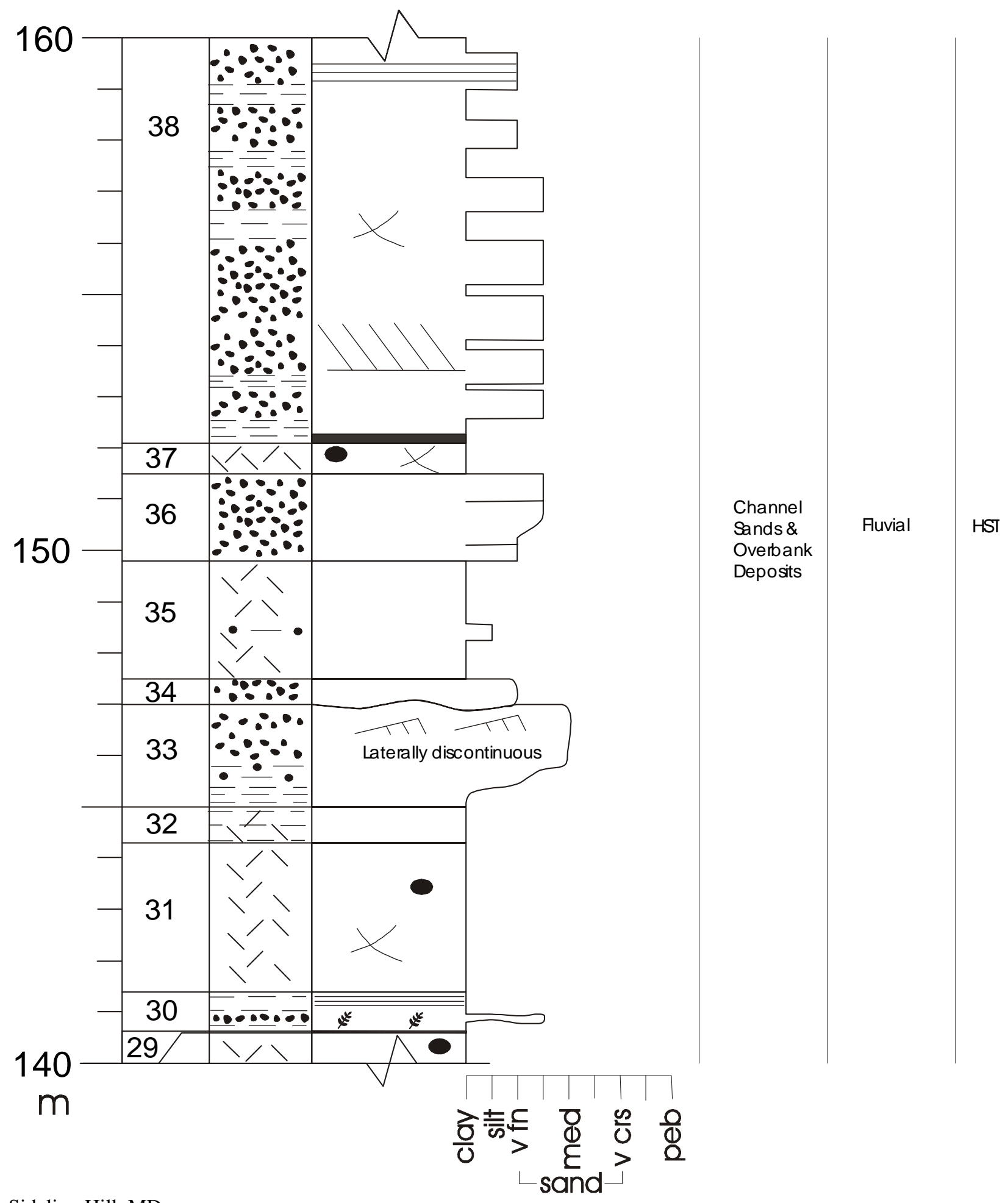

Sideling Hill, MD 


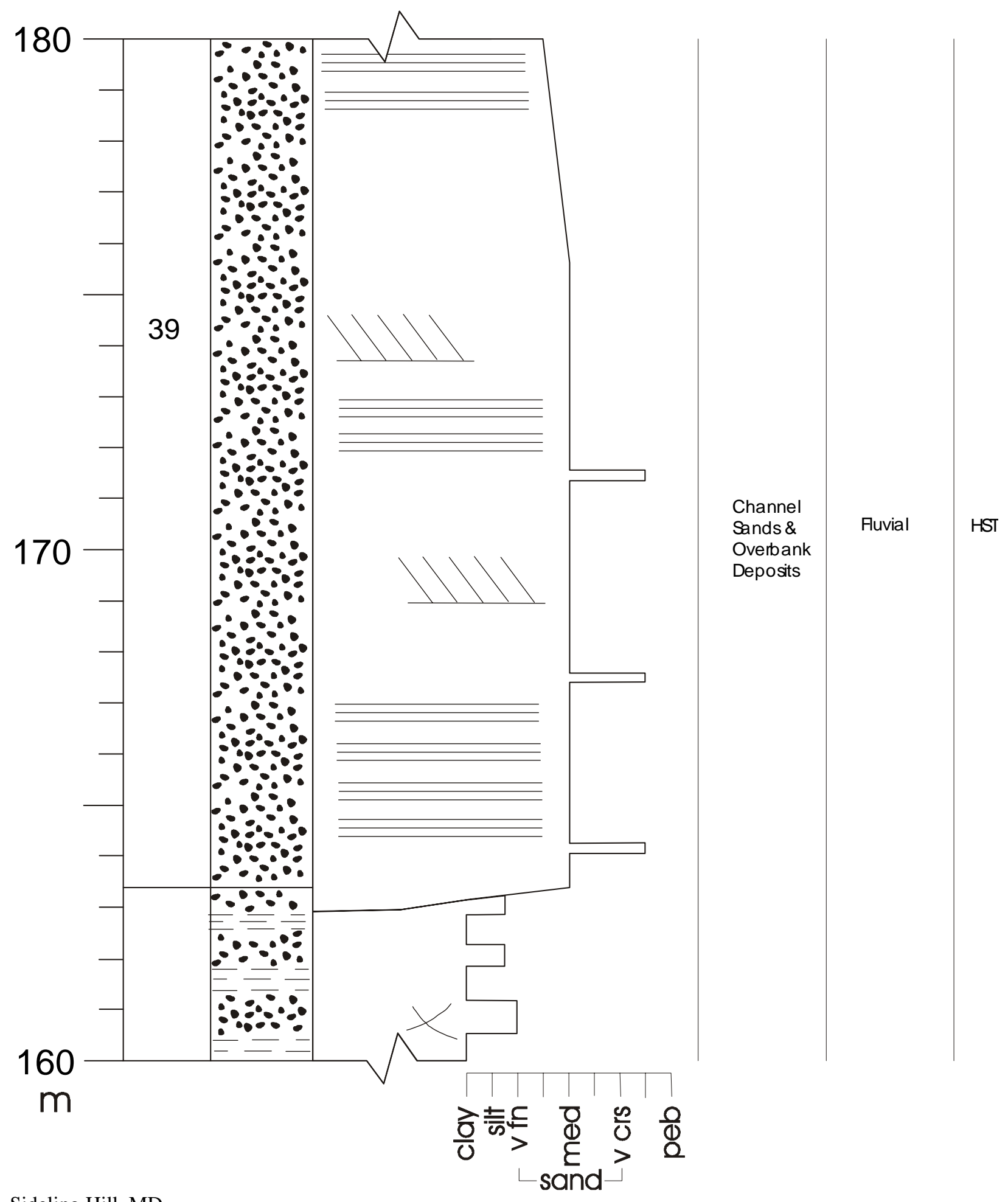

Sideling Hill, MD 


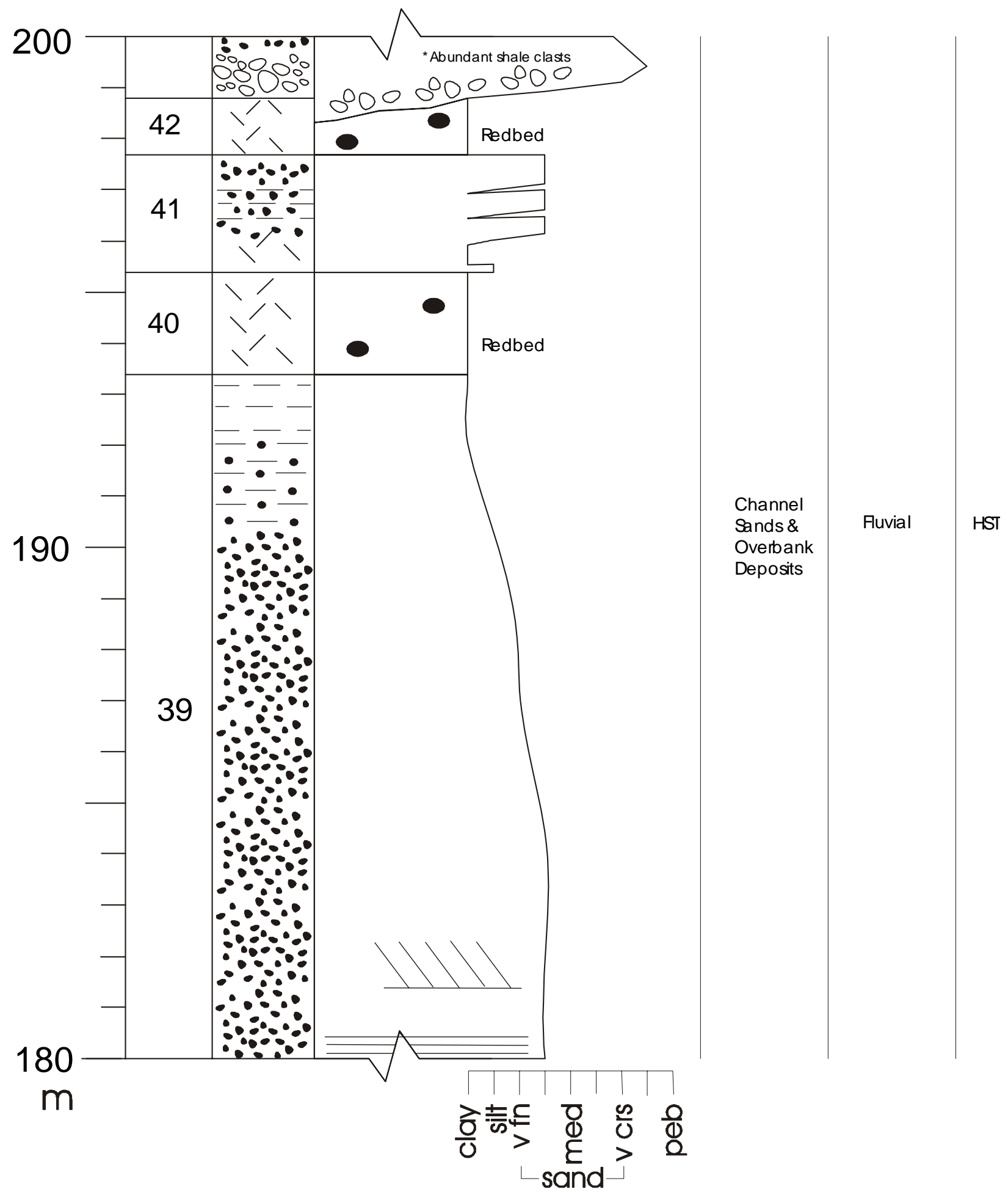

Sideling Hill, MD 


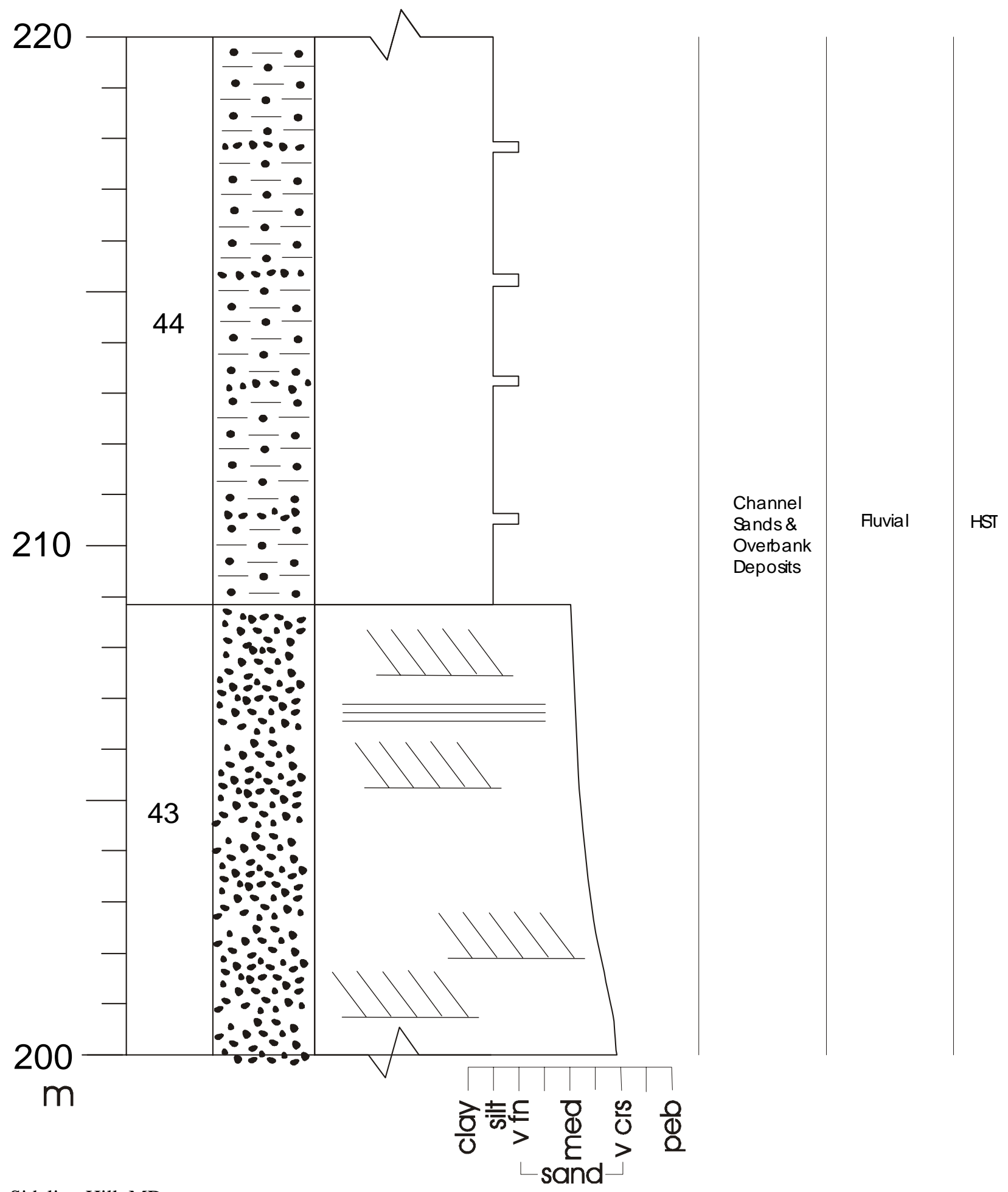

Sideling Hill, MD 


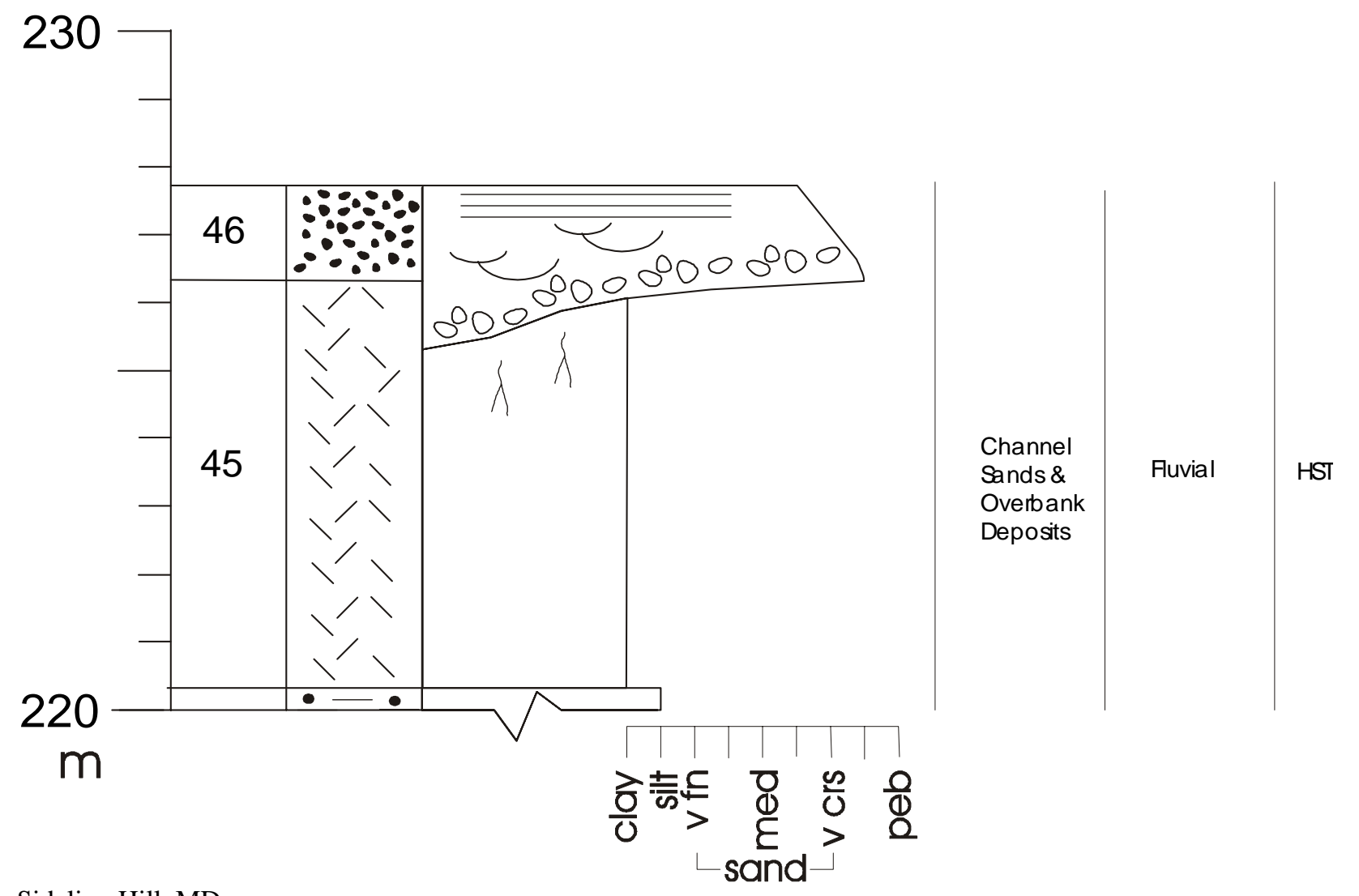

Sideling Hill, MD 


\section{CRYSTAL SPRING PENNSYLVANIA OUTCROP}


Outcrop: Crystal Spring

Date: Saturday September 27, 2003

Location: I - 70 West just west of on ramp at exit 151 Hwy 915. Crystal Spring, PA

UNIT 1: Thickness - $1.0 \mathrm{~m}(3.28 \mathrm{ft})$

Rock name - MUDSTONE

Rock color - Red

Bedding - No apparent bedding

Sed. Structures - Fissle to hackly, possibly some pedogenic slickensides

Trace \& body fossils - No trace or body fossils observed

Comments - Thickness varies do to overlying unit scouring down. Arbitrary basal contact

UNIT 2: Thickness - $9.2 \mathrm{~m}(30.2 \mathrm{ft})$

Rock name - Fine- to coarse-grained conglomeratic SANDSTONE

Rock color - Tan to green-gray (fresh); dark green-gray with rust stains (weathered)

Bedding - Fractured, bedding is destroyed

Sed. Structures - Horizontal stratification with minor low angle planar cross-stratification in the middle.

Trace \& body fossils - No trace or body fossils observed

Comments - Unit is micaceous throughout and highly water saturated. Load casts near base and the shale squeezes up into the sand around the load casts. Conglomeratic sandstone in the upper 2 m. Sharp basal contact.

UNIT 3: Thickness - $8.2 \mathrm{~m}(26.9 \mathrm{ft})$

Rock name - Diamictite with interbedded medium-grained SANDSTONE

Rock color - Dark green-gray (fresh); Dark green-gray (weathered)

Bedding - Thickly bedded

Sed. Structures - No sedimentary structures observed

Trace \& body fossils - No trace or body fossils observed

Comments - Sand body is lenticular. Sandstone is $1.5 \mathrm{~m}$ from base of unit and $1.0 \mathrm{~m}$ thick.

Remainder of unit is diamictite containing scours near base. Gradational basal Contact.

UNIT 4: Thickness - $3.8 \mathrm{~m}(12.5 \mathrm{ft})$

Rock name - SILTSTONE with interbedded SHALE and very fine- to fine-grained

SANDSTONE lenses

Rock color - Tan to gray (fresh); Tan-orange (weathered)

Bedding - Siltstone is indescribable do to cover. Shale is thinly bedded. Sandstone is thin to medium becoming thicker toward top (1-2 beds)

Sed. Structures - Unit contains "laminite" in sandstone and siltstone

Trace \& body fossils - No trace or body fossils observed

Comments - Siltstones are very fissile, weathers like shale, and becoming less abundant toward top. Siltstones are interbedded with sandstone throughout. Shale breaks throughout but minor. Undulatory basal contact.

UNIT 5: Thickness - $7.8 \mathrm{~m}(25.6 \mathrm{ft})$ 
Rock name - Fine-grained SANDSTONE with interbedded SILTSTONE

Rock color - Green to gray-tan (fresh); tan-brown to rusty (weathered)

Bedding - Very thick to thin and gradually becoming destroyed at top

Sed. Structures - No distinct structures. Possible horizontal stratification in sandstone but deeply

weathered. Few minor ripples on bedding surfaces.

Trace \& body fossils - No trace or body fossils observed

Comments - Shale breaks between sandstone beds contain laminations $1 \mathrm{~cm}$ thick. Gradational

basal contact.

UNIT 6: Thickness - $6.3 \mathrm{~m}(20.7 \mathrm{ft})$

Rock name - DIAMICTITE

Comments - Unit contains large clasts of sandstone. Undulatory basal contact.

UNIT 7: Thickness - $2.0 \mathrm{~m}(6.6 \mathrm{ft})$

Rock name - SHALE (Laminite)

Rock color - Olive gray to tan (fresh \& weathered)

Bedding - Laminated

Sed. Structures - No sedimentary structures observed

Trace \& body fossils - No trace or body fossils observed

Comments - Unit is mostly covered, only lower $30 \mathrm{~cm}$ is exposed. Unit contains a squeeze

feature at base similar to a diaper. Some minor diamictite lenses at base of unit. Undulatory basal contact.

UNIT 8: Thickness $-0.8 \mathrm{~m}(2.6 \mathrm{ft})$

Rock name - MUDSTONE

Rock color - Red (fresh \& weathered)

Bedding - No apparent bedding

Sed. Structures - No sedimentary structures observed

Trace \& body fossils - No trace or body fossils observed

Comments - Unit appears deeply weathered by groundwater. Arbitrary basal contact due to cover.

UNIT 9: Thickness - $7.2 \mathrm{~m}$ (23.6 ft)

Rock name - Fine-grained SANDSTONE

Rock color - Light gray (fresh); green-gray to rusty brown (weathered)

Bedding - Thin to medium bedded. Base has very thinly bedded sandstones (undulatory and weathered) between thicker beds

Sed. Structures - Unit contains alternating rippled/laminated sand, and unlaminated sand. The ripples are stacked between thicker unlaminated sandstone beds.

Trace \& body fossils - No trace or body fossils observed

Comments - The very thinly bedded sandstones are between the thicker beds and undulatory as well as weathered. Sharp basal contact.

UNIT 10: Thickness - $7.7 \mathrm{~m}$ (25.3 ft)

Rock name - CONGLOMERATE to medium-grain SANDSTONE

Rock color - Light gray to tan (fresh); medium gray to light gray (weathered) 
Bedding - Massive at base to very thick at top

Sed. Structures - Mostly horizontal stratification at base with minor low angle planar stratification. Middle has low angle planar stratification. Top $1.4 \mathrm{~m}$ has trough crossstratification.

Trace \& body fossils - No trace or body fossils observed Comments - Conglomerate at base $(1.2 \mathrm{~m})$ is quartz rich with granules to pebbles as large as 1 $\mathrm{cm}$ in diameter. Conglomerate abruptly stops and turns into coarse-grained sandstone.

Approximately $1.4 \mathrm{~m}$ from the top and $0.6 \mathrm{~m}$ thick the unit becomes coarse to granular with most distinct trough cross-stratification. The remainder of the unit is medium-grained. Sharp erosional scour base contact $(1.1 \mathrm{~m})$.

UNIT 11: Thickness - $8.4 \mathrm{~m}(27.6 \mathrm{ft})$

Rock name - Medium-grained SANDSTONE with two CONGLOMERATE lags

Rock color - Light gray to olive gray (fresh); olive gray (weathered)

Bedding - Medium bedded overall with some thick beds pinching out randomly

Sed. Structures - Mostly horizontal stratification with some low angle foresets associated with the conglomerate lags and at the very top. Tool marks or load casts on basal bedding surfaces. Trace \& body fossils - No trace or body fossils observed Comments - Conglomerate lags are $25 \mathrm{~cm}$ and $10 \mathrm{~cm}$ thick, respectively. Conglomerate is quartz rich and contains granules to pebble size clasts. Conglomerate lags both have scour bases and are positioned $0.75 \mathrm{~m}$ and $1.6 \mathrm{~m}$ from base, respectively. No shale present in unit. Minor scour sharp basal contact.

UNIT 12: Thickness - $5.4 \mathrm{~m}(17.7 \mathrm{ft})$

Rock name - Coarse to granular and medium-grained SANDSTONE

Rock color - Dirty brown to gray and tan in places (fresh); tan to rusty brown (weathered) Bedding - Mostly covered but probably medium bedded

Sed. Structures - Massive at base in conglomeratic layers to horizonatal stratification toward the top in the medium-grained sandstone.

Trace \& body fossils - No trace or body fossils observed

Comments - In lower $2.0 \mathrm{~m}$, conglomeratic layer changes from a sandy matrix into a courser dirtier layer, and then to a clean-tan-brittle sandy layer, and then grading into a medium-grain sandstone. Gradational basal contact but mostly covered.

UNIT 13: Thickness - $21.6 \mathrm{~m}$ (70.9 ft)

Rock name - SHALE

Rock color - Very dark gray (fresh); dark gray to rusty brown (weathered)

Bedding - Massive but mostly covered by talus

Sed. Structures - Unit consists of splintery pencil cleavage talus material, hackly to fissile

Trace \& body fossils - No trace or body fossils observed

Comments - Unit is mostly talus covered full of splintery dark shale. Basal contact covered.

UNIT 14: Thickness - $3.4 \mathrm{~m}(11.2 \mathrm{ft})$

Rock name - Fine-grained SANDSTONE

Rock color - Dark gray (fresh), yellow-brown (weathered) 
Bedding - Thin to medium bedded

Sed. Structures - Laminated at base. Becomes rippled at top (symmetrical), some ripples contain muddrapes. Near base there are muddrapes between laminations.

Trace \& body fossils - No trace or body fossils observed

Comments - Unit contains nodules at base but weathered out, probably siderite because they weather red. Bedding surfaces contain mica flakes. Sharp basal contact.

UNIT 15: Thickness - $17.2 \mathrm{~m}$ (56.4 ft)

Rock name - Interbedded SHALE and SILTSTONE

Rock color - Dark gray to olive gray (fresh), dark gray to rusty brown (weathered)

Bedding - Mostly covered

Sed. Structures - No sedimentary structures observed

Trace \& body fossils - No trace or body fossils observed

Comments - Mostly talus covered. Sharp basal contact.

UNIT 16: Thickness - $9.3 \mathrm{~m}$ (30.5 ft)

Rock name - Medium- to fine-grained SANDSTONE

Rock color - Dark gray (fresh) to yellow brown (weathered)

Bedding - Medium bedded

Sed. Structures - Horizontal stratification

Trace \& body Fossils - No trace or body fossils observed

Comments - Sharp erosional basal contact 


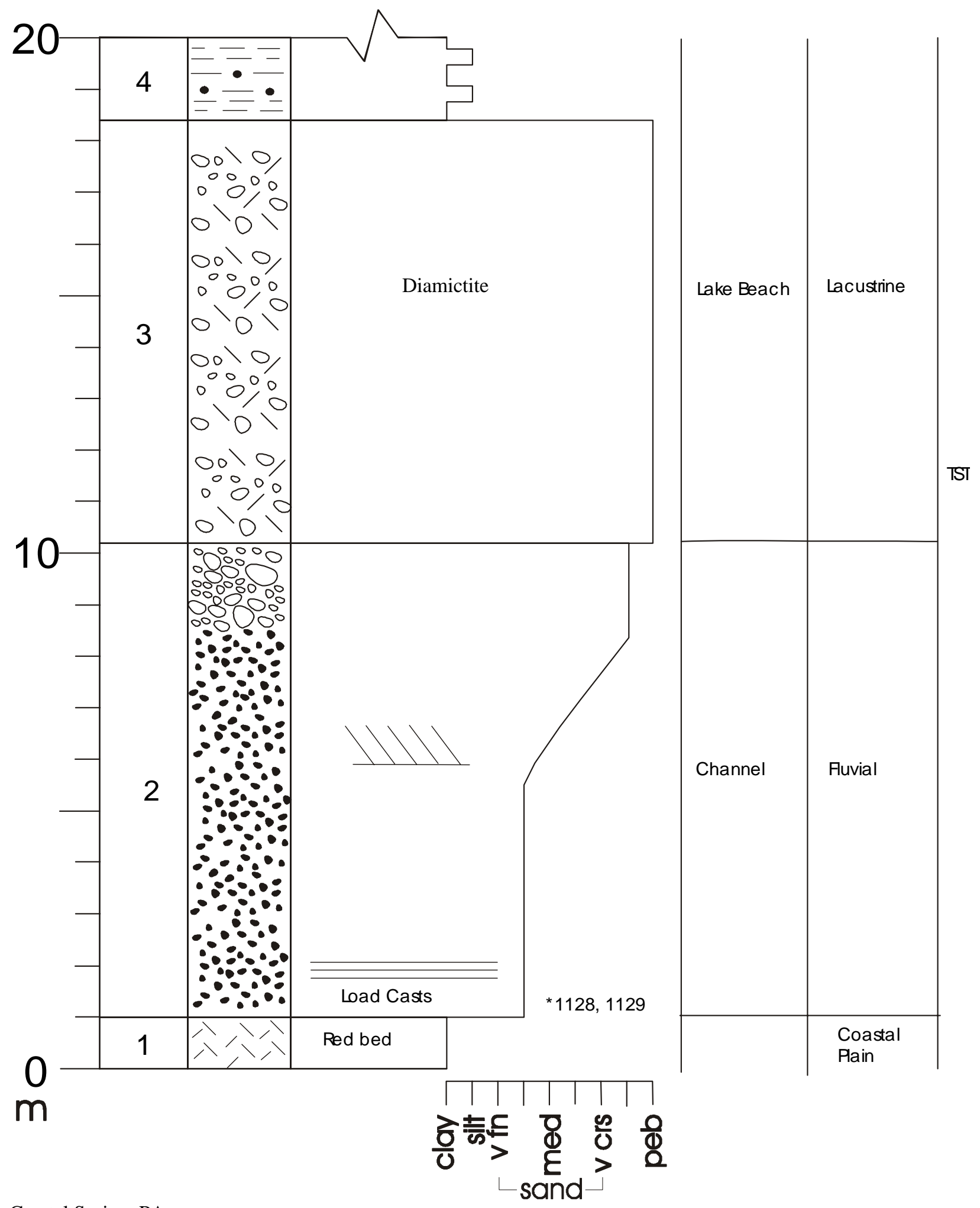

Crystal Spring, PA 


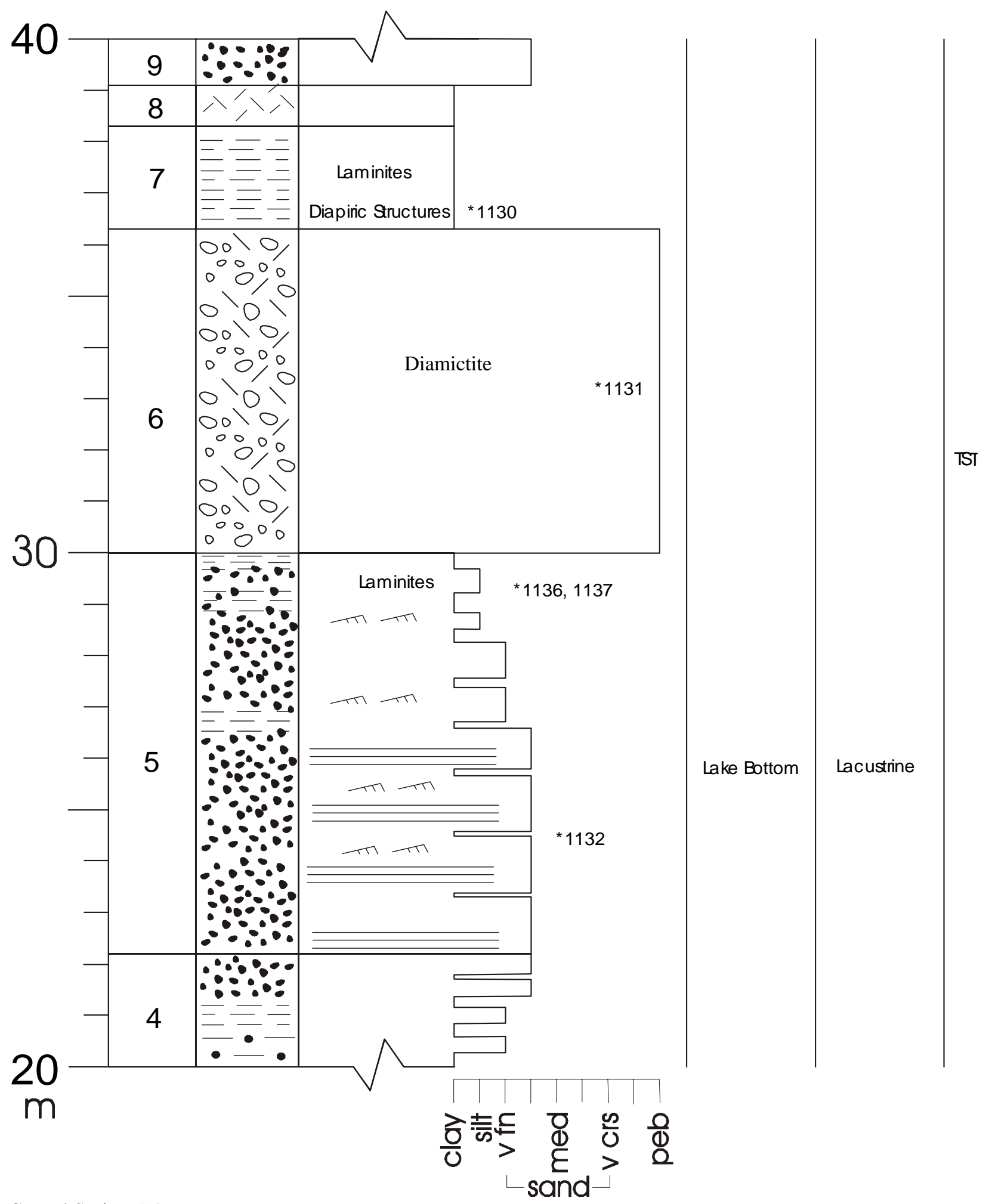

Crystal Spring, PA 


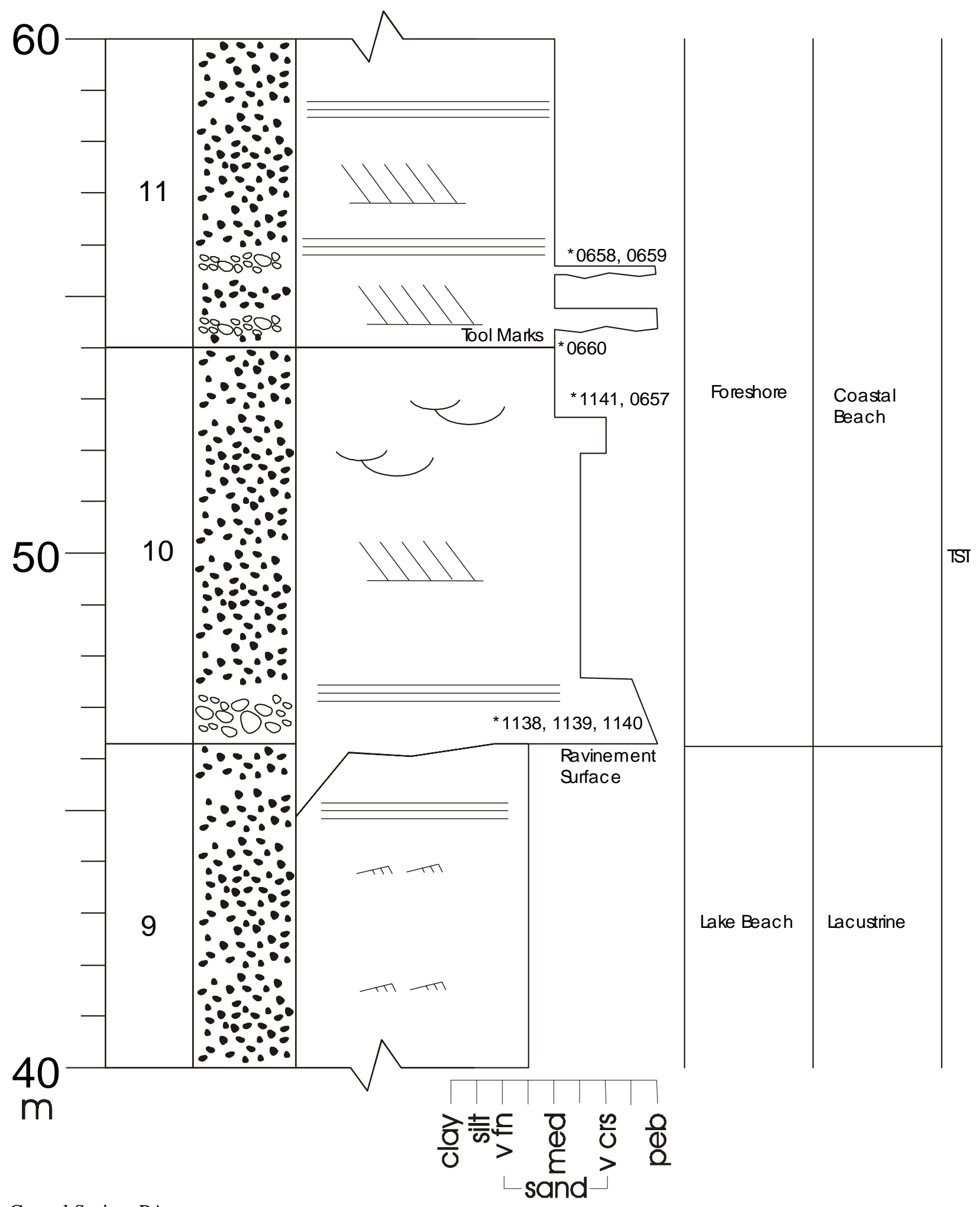

Crystal Spring, PA 


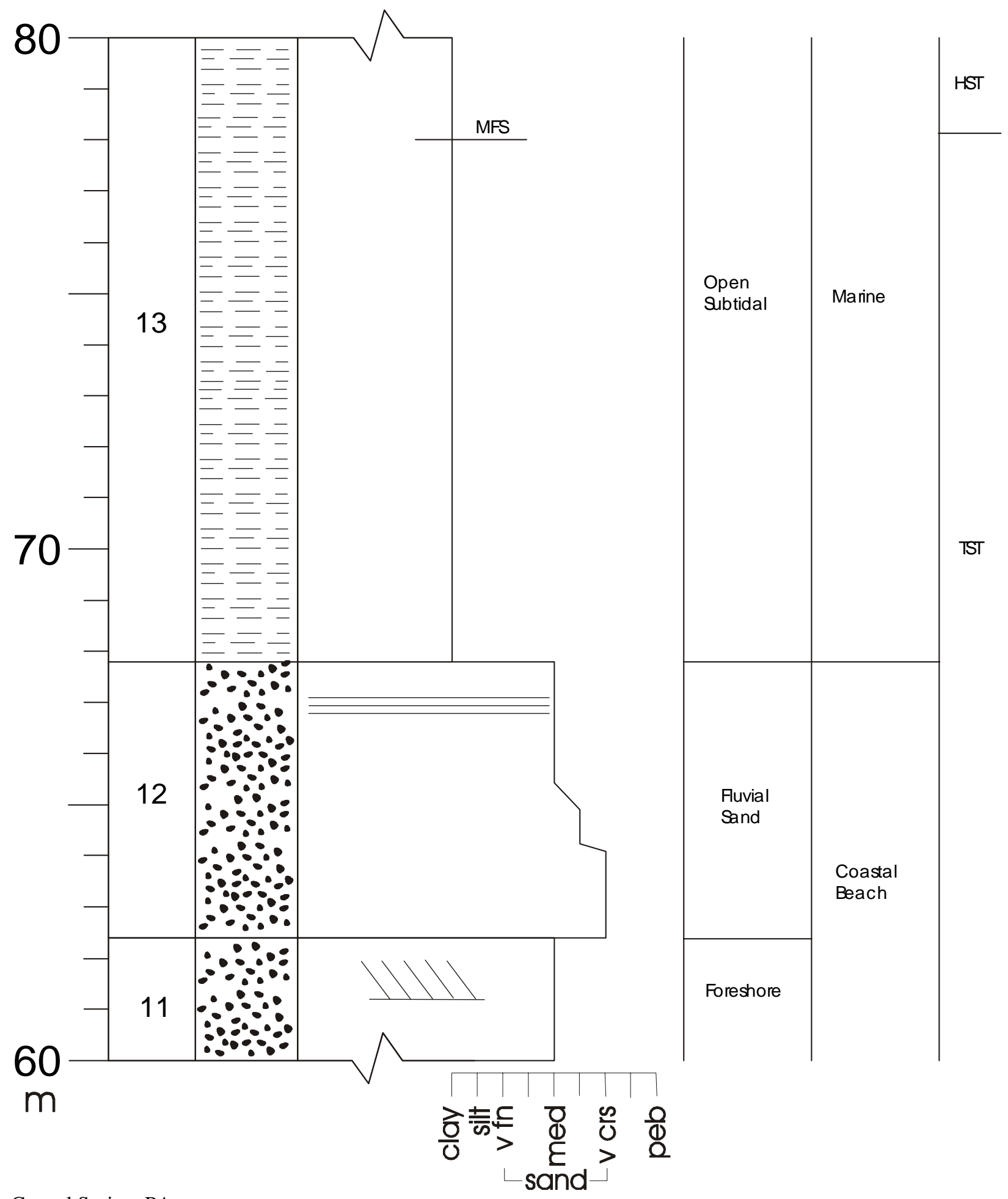

Crystal Spring, PA 


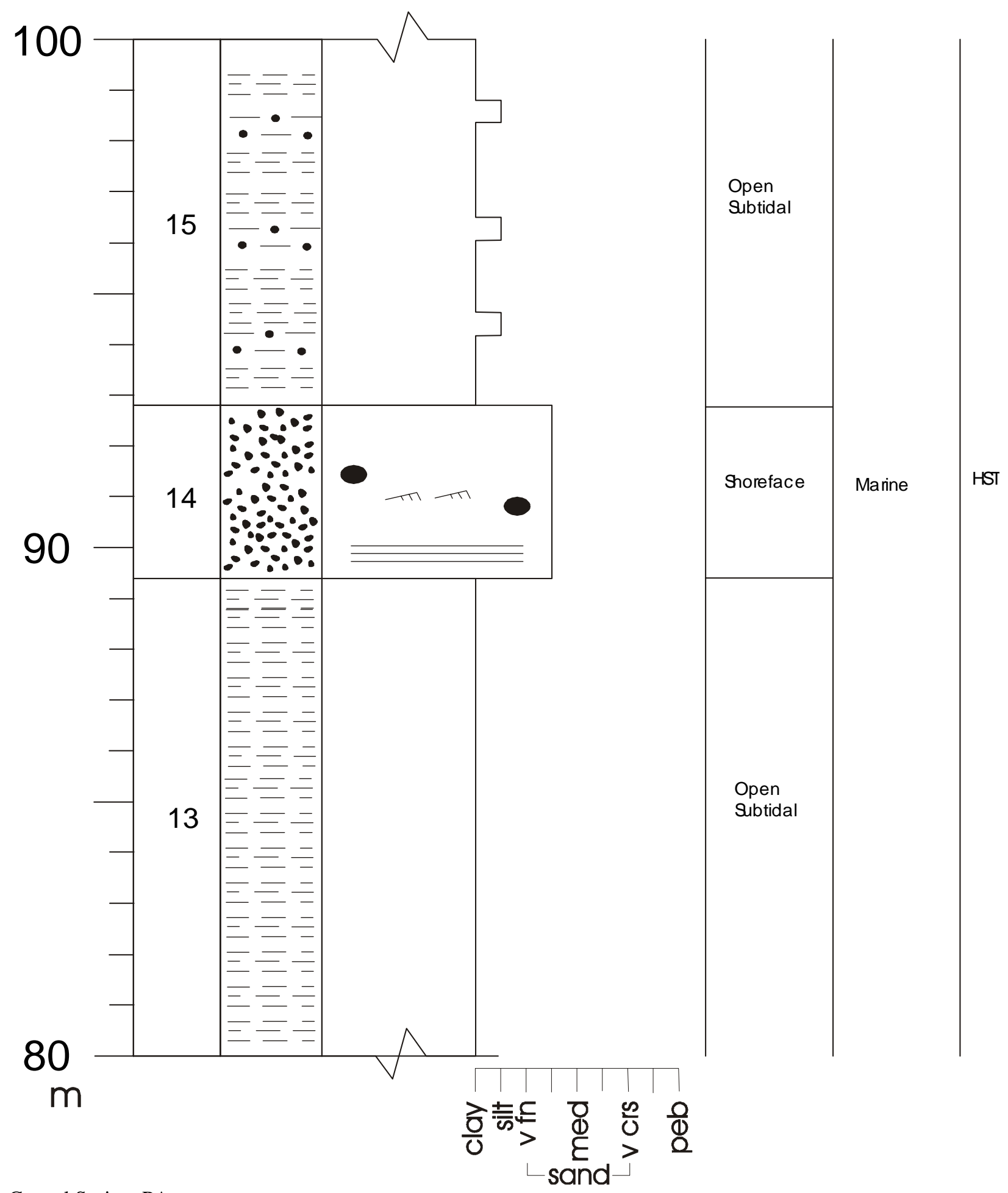

Crystal Spring, PA 


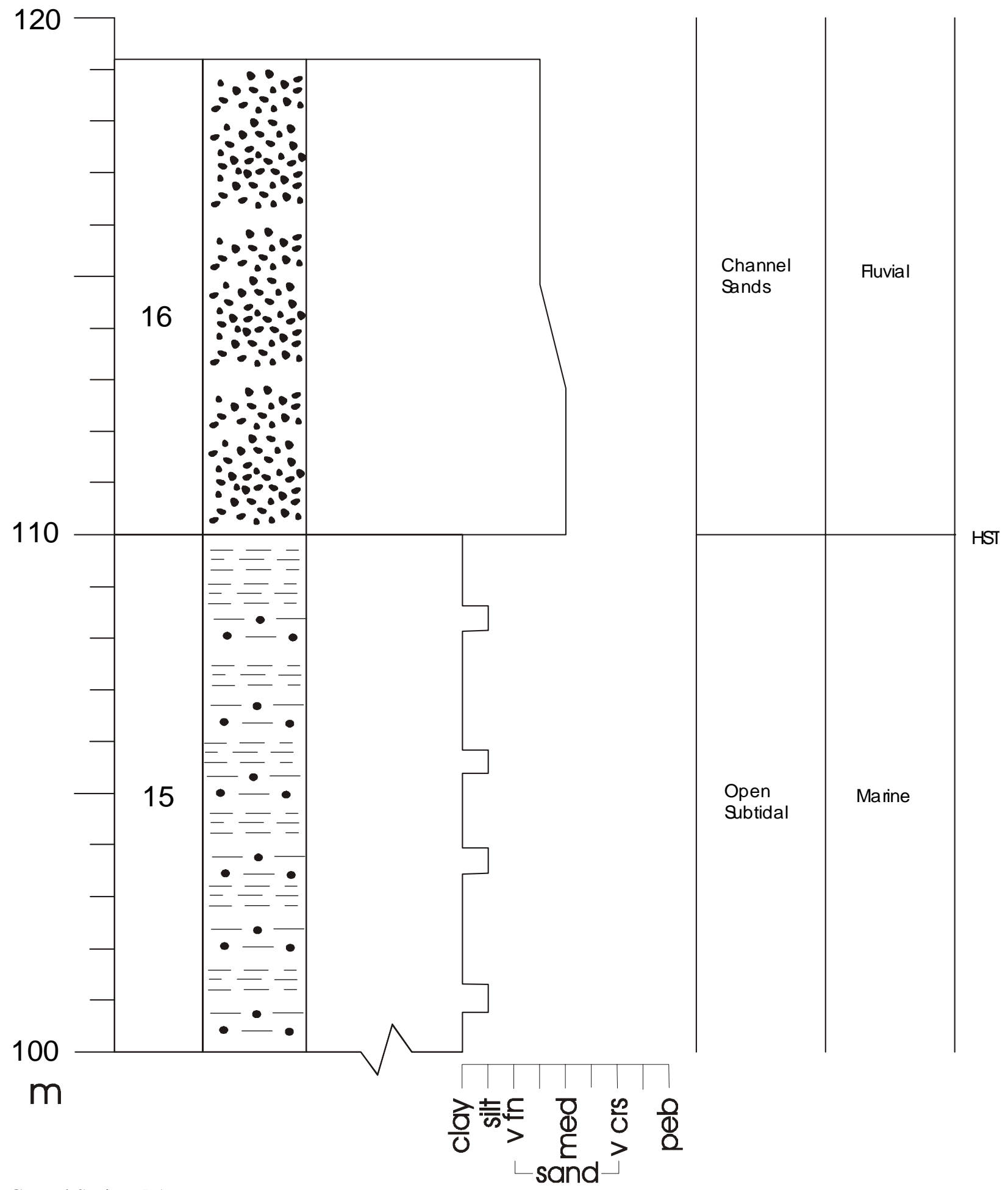

Crystal Spring, PA 


\section{APPENDIX II}

SEQUENCE STRATIGRAPHY 


\section{SEQUENCE STRATIGRAPHY}

\section{Introduction}

Sequence stratigraphy is the study of genetically related facies within a framework of chronostratigraphically significant surfaces. The science of sequence stratigraphy looks at geometric arrangements of strata in a time significant manner. Sequence stratigraphy can be applied at any scale and becomes a powerful tool for evaluating changes in depositional systems and provides a framework for sedimentological analysis. A sequence stratigraphic framework is an important medium to link outcrop and subsurface data and to make comparisons of architectural changes along a depositional profile (Gardner, 2001).

The geomorphology of a depositional system is preserved in a hierarchy of stratigraphic cycles and at the appropriate scale a sequence stratigraphic framework allows the geoscientist to extract this information. Stratigraphic analysis requires a consistent method of correlation at multiple scales (Gardner, 2001). The framework is used for evaluating geologic information of prospects or producing fields. Sequence stratigraphy with the coupling of conventional well logs and core data results in a high-resolution chronostratigraphic analysis for subsurface correlation. When integrated with biostratigraphic and seismic data, well log cross-sections correlated by sequence stratigraphic principles, provide excellent reservoir, source, and seal distribution analyses (Van Wagoner et al., 1990).

Sequence stratigraphic principles were founded on the concept of accommodation space and stratigraphic base level. Accommodation space is the potential space available for sediment accumulation, control of cyclic stacking patterns, preservational trends, and geomorphic landscapes of stratigraphic cycles. The accommodation space provided by a basin is the sum of tectonics, compaction, lithospheric compensation of loads, and relative sea level changes. 
Stratigraphic base level describes the balance between accommodation and the movement of sedimentary masses by surficial processes that erode, transport, and deposit sediment. When sea level and accommodation space fluctuate, sedimentary loads react by building stratal units. These stratal units range from individual lamina up to a sequence and form a stratigraphic hierarchy of sedimentary rock packages. Stratal units share two fundamental properties: (1) each unit is a genetically related succession of strata bounded by chronostratigraphically significant surfaces, and (2) surfaces are single physical boundaries separating the strata below from the strata above over the extent of the surface (Van Wagoner et al., 1990).

The depositional sequence is the basic unit of sequence stratigraphy and has been defined as a relatively conformable, genetically related succession of strata bounded by unconformities or their correlative conformities (Mitchum, 1977). Response to relative changes in sea level form the boundaries of the sequence. Each sequence is composed of system tracts known as: lowstand, shelf-margin, transgressive, and highstand. The building blocks of sequences are the system tracts that are defined as a linkage of contemporaneous depositional systems composed of parasequences and parasequence sets. The parasequence is defined as a relatively conformable, genetically related succession of beds or bedsets bounded by marine-flooding surfaces or their correlative surfaces (Vail et al., 1990). Parasequence sets are a succession of genetically related parasequences that form a distinct stacking pattern, bounded by major marine-flooding surfaces and their correlative surfaces (Van Wagoner et al., 1990). Systems tracts and stacking patterns of parasequence sets, usually shallowing-upward and coarsening-upward, provide a high degree of predictability within the chronostratigraphic framework of sequence boundaries. Vertical facies analysis should be done within this stratigraphic framework to interpret lateral facies 
relationships accurately. The lateral facies relationship predictability is especially useful when analyzing source, reservoir, and seal distribution within a basin or producing field.

The purpose of this paper is to discuss the fundamental concepts of sequence stratigraphy and give some examples of the application of its framework.

\section{History of Sequence Stratigraphy}

Sloss (1963) is recognized and given credit for developing the unconformity-bounded sequence as a stratigraphic tool. Sloss's ideas provided the foundation for sequence stratigraphy but found little support in the 1950's and 1960's. Modern sequence stratigraphy found its roots in the context of seismic stratigraphy. P.R. Vail and others of Exxon published a group of seminal articles in the AAPG Memoir 26 presenting the concepts of eustasy and subsequent unconformity-bounded stratal patterns related to seismic reflection data. Mitchum (1977)

redefined the concept of the sequence into the definition that is used today. Later, Vail modified Sloss's (1963) concept of the sequence to incorporate a smaller amount of geologic time and be controlled primarily by eustasy.

The advent of improved seismic-reflection data and the new concepts of sequence stratigraphy in the late 1970's represented a major step forward for the science of stratigraphic analysis and sedimentology. However, the techniques used in seismic data were useful only on the basin scale, and logs, cores and outcrops were not being utilized in a sequence stratigraphic context. At this point in the evolution seismic stratigraphy did not offer the necessary precision to analyze sedimentary stratal packages at the reservoir scale. Not until the 1980's did the realization come about that sequences could be broken down into smaller stratal units called systems tracts. These systems tracts could further be classified as Type- 1 or Type- 2 depending 
on which tracts they contained and the type of sequence boundary present. Exxon stratigraphers began to analyze upward-shoaling cycles and identified stacking patterns of siliciclastic strata in well logs, cores, and outcrops. These stratal units and their component sedimentary layers were recognized as the building blocks of systems tracts and sequences. The stacking patterns improved subsurface correlation of time and facies and it was quickly realized that a very high-

resolution chronostratigraphic framework of sequences and sequence boundaries, defined by the relationship of strata, could aid in stratigraphic analysis of facies at the reservoir scale (Van Wagoner et al., 1990).

\section{Hierarchy of Stratal Units}

The lamina is the smallest recognized aspect of the stratal unit in sequence stratigraphy. The sequence is the largest aspect recognized. A hierarchy can be constructed from the lamina to the sequence, and its use in correlating time and facies is the key to application of the sequence stratigraphic model. Each stratal unit is identified by the physical relationship of the strata. Included in this relationship are geometry and lateral continuity of the surfaces bounding the units, lateral geometry within the unit, and vertical-stacking patterns. This paper will discuss each aspect of the hierarchy separately beginning with the lamina-bedset, parasequence, parasequence set, systems tracts, and sequence.

\section{Lamina, Lamina Sets, Beds, Bed Sets}

The lamina is the smallest megascopic layer of a stratal unit. It is characteristically uniform in composition and texture and never internally layered. Lamina bounding surfaces form very rapidly and cover a much smaller areal extent than their encompassing beds. The 
laminaset are a conformable succession of lamina bounded by surfaces of erosion, nondeposition, or correlative conformities. Their role in the stratal unit consists of a group of conformable lamina that make up distinct structures in a bed. Laminasets are commonly found in wave or current-rippled beds and form rapidly. A bed is a group of genetically related lamina or laminasets (not all beds contain laminasets) bounded by surfaces of erosion, nondeposition, or correlative conformities. Deposition of beds are episodic to periodic and include storms, floods, seasonal changes, etc. Bounding surfaces form over a wide range of time and separate younger from older strata. Facies changes are bounded by bedding surfaces and can be useful for chronostratigraphy in some situations. The bedset is a genetically related conformable succession of beds bounded by surfaces of erosion, nondeposition, or their correlative conformities. The bedset is always of different composition, texture, and/or sedimentary structure than the beds above and below. Bedsets and bedset surfaces form over a longer period of time than beds and commonly have a larger lateral extent than bedding surfaces.

\section{Parasequences}

A parasequence is defined as a relatively conformable succession of genetically related beds or bedsets bounded by marine-flooding surfaces or their correlative surfaces (Van Wagoner et al., 1990). Parasequences and parasequence sets are the building blocks of system tracts and sequences (Mitchum \& Van Wagoner, 1991). Parasequences have been identified in shelf, estuarine, tidal, beach, deltaic, and coastal-plain environments (Van Wagoner, 1985 in Van Wagoner et al., 1990). Identifying parasequences in fluvial deposits and deep-water basin or slope deposits is difficult because neither are typically influenced by changes in water depth. Parasequences are more commonly formed in a progradational fashion where sandstone bedsets 
are deposited progressively farther basinward. This pattern results in a characteristic shoalingupward association of facies as younger bedsets are deposited in increasingly shallower water. In a typical coarsening-upward parasequence sandstone/mudstone ratio increases, sandstones coarsen, and bedsets thicken. In a fining-upward parasequence sandstone/mudstone ratio decreases, sandstones become finer grained, and bedsets thin (Van Wagoner et al., 1990).

A gradual decrease in water depth is interpreted for both the coarsening- and finingupward parasequences. Parasequences are thought to prograde and fill the basin from the margin toward the center with a sediment source as the river mouths at the shoreline. Shallow-marine parasequences form when the rate of sedimentation in a particular environment (tidal-flat, beach, deltaic) is greater than the rate of accommodation space. Accommodation space, as defined by Van Wagoner et al., (1990) is the new vertical space available for sediments to accumulate and is interpreted to be a function of subsidence and eustasy.

\section{Parasequence Boundaries}

Parasequence boundaries form when the rate of sediment supply at the shoreline is less than the rate of accommodation space available. Conditions such as these, cause the shoreline to retreat rapidly in a landward direction and very little marine sediment is preserved in the stratigraphic record. The only indication that the rate of accommodation exceeded the rate of sedimentation is a marine-flooding surface, also known as a parasequence boundary. Three common mechanisms have been well documented as the initiators of marine-flooding surfaces. The first is a relatively rapid increase in water depth caused by compaction of prodelta mudstone in a delta lobe following distributary-channel avulsion (Fazier, 1967 in Van Wagoner et al., 1990). A second mechanism is a rapid relative rise in sea level caused by subsidence along 
tectonically active faults (Mitchum \& Van Wagoner, 1991). Van Wagoner et al (1990) exemplified this mechanism with a study by Plafker (1965) and Plafker and Savage (1970). In the example, two earthquakes, one in Alaska and one in Chile, produced coastal subsidence of 6.5 and $9 \mathrm{ft}$, respectively. A zone of subsidence was recorded 600 miles long and 70 miles wide along the Chilean coast. This rapid subsidence would drown low-lying coastal inland areas producing a parasequence boundary. Another example of basin subsidence is the Holocene Mississippi Delta region of the Gulf Coast basin and the western foredeep area of the Cretaceous Interior Seaway (Nummedal \& Swift, 1987). The third mechanism is eustasy.

The parasequence boundary or marine-flooding surface is planar, occurring on a local to basinal extent, and characteristically of minor topographic relief over large areas. An example of this is given by Hettinger et al. (1993) as they state, "... a marine-flooding surface that can be traced over distances of several kilometers across which a landward shift in depositional environments occurs”. Marine-flooding surfaces sharply separate shallow-water rocks from the overlying deeper-water rocks. An example of this is lower-shoreface sandstones sharply overlain by deep-water shelf mudstones. Flooding surfaces usually exhibit submarine erosion and/or nondeposition and indicate a minor hiatus. Erosion associated with flooding surfaces range from a few inches to tens of feet. Several feet of erosion is common in most situations. These surfaces of erosion are commonly referred to as ravinement surfaces or transgressive surfaces of erosion (TSE), this paper will use the ravinement surface.

The material eroded during shoreline retreat and ravinement is derived from the underlying strata by shoreface erosion during a marine transgression and produces a transgressive lag. Hettinger et al. (1993) explains an example of such a transgressive lag. In the Kaiparowitz Plateau of southern Utah sharp-based conglomerate layers are found along flooding 
surfaces atop parasequences. Many, if not all, of these layers form as lag deposits on flooding surfaces and are interpreted as transgressive lags or ravinement surfaces. Eroded material is concentrated as a discrete bed on the transgressed surface (Van Wagoner et al., 1990). As sea level rises the shoreface retreats and the ravinement surface cut by this process will rise toward the basin margin. Preservation of the surface is a direct result of the depth of shoreface erosion relative to the thickness of the coastal plain deposits above the sequence boundary and the rate at which sea level rises (Nummedal \& Swift, 1987). Ravinement surfaces should be recognized not only as erosive but also as mechanism that transfers sediment. During storm currents (and relative sea level rise) sediment eroded from the shoreface is commonly redeposited above the ravinement surface in a seaward direction. As sea level continues to rise the eroded sediment may be preserved under steadily climbing marine deposits. Examples of ravinement surfaces may be found in Nummedal and Swift (1987) in their study of Holocene and Cretaceous transgressive stratigraphy.

\section{Parasequence Set}

A parasequence set is defined as a succession of genetically related parasequences forming a distinctive stacking pattern bounded by major marine-flooding surfaces and their correlative surfaces. Stacking of parasequences within a set are: progradational, retrogradational, or aggradational. Which of the three a parasequence set is defined as depends on the ratio of depositional rate to accommodation rate. In a progradational parasequence set successively younger parasequences are deposited farther basinward and the rate of deposition overcomes the rate of accommodation. Posamentier et al (1992) describes this situation during the Pleistocene-Holocene transition when the rate of relative sea level rise was increasing but the 
high sediment influx of the Mississippi Delta caused a basinward shift of the shoreline.

Muntingh and Brown (1993) stated that during progradational sequence sets of the Orange Basin, western offshore, South Africa, the component lowstand systems tracts shifted far into the basin. In the Parkman parasequence set of the Late Cretaceous Mesaverde Formation, Powder River basin, Wyoming, successively younger parasequences move basinward producing a characteristic progradational pattern on well logs (Van Wagoner et al., 1990). In a retrogradational parasequence successively younger parasequences are deposited farther landward and the rate of accommodation is greater than the rate of deposition. This situation exist in parts of The Texas Gulf Coast system where sediment influx is less than the rate of accommodation space and the system is characterized as either transgressive or stationary (Posamentier et al., 1992). Each parasequence in a retrogradational parasequence set progrades but the parasequence set deepens upward in a "transgressive" fashion. Retrogradation is a backstepping or landward retreat of a prograding parasequence set as accommodation space increases relative to sedimentation. The Vedder and Jewett sands of the San Joaquin Basin, California, represent a retrogradational parasequence set (1500-ft) of a transgressive systems tract (Tye et al., 1993). Aggradational parasequence sets have successively younger parasequences deposited on top of one another and no significant lateral shift occurs. The rate of accommodation and sedimentation are approximate to one another (Van Wagonger et al., 1990). A positive aspect of aggradational parasequence sets is that they have a high potential to supply basin-floor fans with large volume of reservoir-quality sand during times of lowstand fluvial incisement (Muntingh \& Brown, 1993).

Successively younger parasequences of a progradational parasequence set contain greater depostional porosity sandstone with a higher percentage of rocks being deposited in increasingly 
more coastal-plain environments than underlying parasequences. Ultimately the younger parasequences will be thicker and coarser than the older parasequences in the set. The parasequence set will be terminated when an abrupt increase in water depth floods across the top of the youngest parasequence and superimposes deep-water marine shale on shallow-marine mudstone. Succeessively younger parasequences of a retrogradational parasequence set contain more mudstone or shale. This parasequence set is characterized by a higher percentage of rocks deposited in deeper-water marine environments than underlying parasequences. Examples of such environments are lower shoreface, delta front, and/or shelf. Rocks deposited in a shelf environment are typically the youngest parasequence in the set and tend to be thinner than older parasequences below. The aggradational parasequence set does not exhibit significant change in the facies, thicknesses, and sandstone mudstone ratios, nor does it change laterally to any measurable degree. However, the aggradational parasequence thickens vertically.

\section{Sequences}

Sequences are defined as a relatively conformable succession of genetically related strata bounded by unconformities or their correlative conformities (Mitchum, 1977). The stratal building blocks of the sequence are parasequences and parasequence sets. Unconformities are surfaces separating younger from older strata along which there is evidence of subaerial erosional truncation and in some areas correlative submarine erosion, or subaerial exposure, with a significant hiatus indicated (Van Wagoner et al., 1988 in Van Wagoner et al., 1990).

Evaluating an unconformity involves several factors: angular discordance, nature of contact, hiatus, cause and duration of the break, and areal extent of the break (Weimer, 1992). Unconformities should not be confused with ravinement surfaces (transgressive surface of 
erosion, (TSE) as unconformities represent a much more time significant hiatus than do ravinements. The Kaiparowitz Plateau of southern Utah characterize this transgressive surface of erosion. Heterolithic estuarine deposits are separated from the overlying shoreface sandstone by a widespread erosion surface covered by a sub- to well-rounded conglomerate. This ravinement surface or TSE falls within the transgressive systems tract (Hettinger et al., 1993). Unconformity is a term reserved for major breaks in the record, whereas minor breaks referring to nondeposition or scour surfaces within a depositional environment are called diastems. Six major unconformities exist in the sedimentary record of the North American craton from late Precambrian to present. The approximate dates of these maximum regressions are: (1) very late Precambrian, (2) early Middle Ordovician, (3) early Middle Devonian, (4) “post-Elvira Mississippian, (5) early Middle Jurassic, and (6) late Paleocene (Sloss, 1963). Unconformities are considered to be a laterally continuous, widespread surfaces, spanning an entire basin, and occur synchronously in basins around the world. This makes for excellent use with global correlations by establishing continuity of lithogenic units. To establish time relations among strata accurately one should use independent methods to establish time surfaces. Otherwise, the events recorded by the unconformity cannot be accurately reconstructed (Weimer, 1992).

Sequences are subdivided into systems tracts which are defined as a linkage of contemporaneous depositional systems. Depositional systems are defined as three-dimensional assemblages of lithofacies (Van Wagoner et al., 1990). Within a sequence four systems tracts can be identified and labeled as such. Systems tracts include lowstand, shelf margin, transgressive and highstand and are descriptive terms for the position within a sequence. Sequences can farther be broken down into Type 1 and Type 2 depending on arrangement of strata into systems tracts between sequence boundaries and types of bounding unconformities. 
Type 1 sequences are bounded by Type 1 unconformities and their correlative conformities and contain the lowstand, transgressive, and highstand systems tracts. Type 2 sequences are bounded by Type 2 unconformities and are composed of shelf-margin, transgressive, and highstand system tracts. Type 1 unconformities develop when the rate of eustatic fall is greater than the rate of subsidence at the depositional-shoreline break. This produces a relative fall in sea level at that position. Means of identifying Type 1 sequences are: (1) subaerial erosion and truncation commonly occurring as incised valleys of the exposed shelf, (2) onlap of coastal strata onto the sequence boundary, (3) abrupt shallowing of facies and basinward shift signifying a relative drop in sea level, and (4) these criteria must be evident on a regional basis. Identifying a Type 2 sequence involves (1) a downward shift of coastal onlap, (2) no incised valley formation and only moderate subaerial exposure and erosion on the shelf (3) a vertical change in stacking patterns of strongly prograding to prograding/aggrading (Mitchum \& Van Wagoner, 1991).

A Type 1 sequence has different lowstand geometry configurations when deposited on a shelf-break margin compared to a ramp margin. Systems tracts deposited in a basin with a shelfbreak are considered to be the idealized Type 1 sequence. Shelf-break margins contain: (1) welldefined shelf, slope, and basin-floor topography, (2) abrupt shelf-break separating shallow dipping shelf deposits from steeply dipping slope deposits, (3) abrupt transition from shallow water into deeper water, (4) shelf incision as a response to relative sea level fall below the shoreline break, and (5) deposition of submarine fans on the basin floor. Other conditions must exist in order to produce a Type 1 sequence and they are: (1) large fluvial systems to deliver sediment to the basin (2) accommodation space to preserve parasequences and (3) a relative fall of sea level large enough to produce a lowstand systems tract beyond the shelf break. 
A Type 1 sequence with a ramp margin is characterized by: (1) low-angle dips less than one degree, (2) no abrupt breaks separating dip angles, (3) no abrupt change in water depth, (4) moderate incision of shelf, and (5) basin-floor submarine fans unlikely to be deposited on a ramp margin.

A Type 2 sequence can be recognized with the lowest systems tract being the shelfmargin. This tract can be deposited anywhere on the shelf and have one or more weakly progradational to aggradational parasequence sets. These parasequence sets are made up of shallow-marine parasequences and updip deposits of the coastal plain. The Type 2 sequence boundary is the base of the shelf-margin system tract and the top is a major marine flooding surface over the shelf. The transgressive and highstand systems tracts are very similar in a Type 1 and Type 2 sequence.

\section{Lowstand Systems Tract (LST)}

The lowstand systems tract contains a basin-floor fan, a slope fan, and a lowstand wedge. The LST is deposited during a relative sea level fall and in turn a slow relative rise. A basinward shift in facies is the essence of the lowstand systems tract. This shift occurs when non-marine to shallow-marine strata, deposited on top of a sequence boundary, sit directly above deep-water marine strata. The facies shift can be related to erosion of the intervening facies or nondeposition due to the rapid drop in relative sea level and rapid shift of environments. The shelf is subaerially exposed after sea level falls and incision occurs producing incised valleys on a Type 1 unconformity. Coastal plains are by-passed in the sea level fall resulting in submarine basin-floor fans being deposited (Wright \& Marriott, 1993). The lowstand wedge contains one or more progradational parasequence sets building a wedge seaward of the shelf break that 
onlaps the slope of the preceeding sequence. The landward part of the wedge contains incised valley fills and associated lowstand shore-line deposits on the upper slope or shelf. The seaward portion of the wedge is mostly shale and downlaps onto the slope fan (Van Wagoner et al., 1990).

Lowstand sytems tracts can be deposited in one of two ways. The first is a normal regression. In this scenario the shoreline moves seaward due to overwhelming sediment influx that exceeds the rate of accommodation space. Regression can occur under conditions of relative sea level rise as long as the rate of sediment influx is greater than the rate of accommodation space provided. The second scenario is one of forced regression. In this situation the shoreline moves seaward in response to a relative sea level fall and is independent of the rate of sediment influx. This relative sea level fall is also independent of a scale and time. Posamentier et al. (1992) conducted a study of a small lacustrine fan-delta at East Coulee, Alberta Canada. In the study a lake level fall resulted in subaerial exposure of a relatively steep delta front causing an incised valley and deposition of a lowstand delta. This response to base-level fall is typical on basin margins with high-relief slopes. As base-level continued to fall a second lowstand delta formed on much shallower slopes. This example constitutes a forced regression and is typical of lowstand systems tracts on basin margins of gentle slope angles. The Hudson River system during the late Quaternary incised a valley system during a relative sea level fall. The following transgression filled only half of the valley. The lobate feature where the valley system flares is interpreted as a lowstand delta and believed to have been deposited during a forced regression (Posamentier et al., 1992). In some cases a regression can be the result of several factors. During the Laramide Orogeny, the Western Interior Cretaceous basin was segmented into structurally smaller basins of which the Denver basin is the largest. The Skull Creek Shale and 
the Mowry Formation record a transgressive-regressive-transgressive cycle in the rock record. A large portion of the Western Interior was submerged by the Skull Creek highstand. The subsequent regression resulted from one or more of the following: excess sediment supply (normal regression), a relative sea level fall (forced regression), or movement along the Transcontinental arch (Weimer, 1992).

Shelf angle greatly affects the regression during relative sea level fall. A shallow sloping shelf will greatly accelerate a forced regression where as a steeply sloping shelf will result in much slower regression. Posamentier et al. (1992) gave an example of a relative sea level fall of $10 \mathrm{~m}$, exposing a shoreface profile of 0.5 degrees will shift the shoreline about $1 \mathrm{~km}$. Alternatively, a more shallow sloping profile of 0.02 degrees will result in a seaward shift of approximately $29 \mathrm{~km}$.

\section{Incised Valleys}

Incised valleys are entrenched fluvial channels extending basinward and cutting into underlying strata as a result of relative sea level fall. Incised valleys are bounded below by the sequence boundary and above by the first major marine flooding surface. They range in depth from tens to several hundreds of feet and in width from several to tens of miles. Adjacent to the incised valley (type 1 unconformity) is the correlative subaerial exposed shelf typically marked by well drained, mature, root and soil horizons.

Blum (1993), in his study of Late Quaternary architecture of incised valleys on the upper Colorado river in Texas, stated that, “unconformities representing valley incision and/or sediment bypass developed approximately 14-12 ka, whereas unconformities representing floodplain abandonment and soil formation accompanied by continued lateral migration of 
channels developed approximately 5 and 1 ka”. Potential for soil horizon preservation depends on the rate and nature of the following transgression (Wright \& Marriott, 1993).

The first phase of valley formation is erosion, sediment bypass through the valley, a basinward shift in facies, and subsequent deposition at the lowstand shoreline due to a relative drop in sea level. Van Wagoner et al (1990) gives an example from the Clareton field in the eastern Powder River basin, Wyoming, of this basinward shift in facies. As described, the valley filled with fine- to medium-grained sandstone and mudstone of a fluvial to estuarine environment. These sandstones lying directly on top of the shelf mudstones represent a basinward shift in facies, and associated truncation, sharply mark the underlying sequence boundary. During the second phase the valley fills, sediment is deposited in response to a relative sea level rise during the following transgressive systems tract. Van Wagoner et al (1990)'s example further explains the valley in-fill as shallow-marine retrogradational parasequence sets overlie the fluvial or estuarine incised-valley fill.

Upper incised valley depositional environments include mudstones or coals, coastal-plain sandstone, fluvial sandstone, braided-stream and estuarine sandstone. The Kaiparowits Plateau of sourthern Utah exemplifies this succession of transgressive systems tract deposition. The strata characterizes amalgamated braided river sandstones passing upward into heterolithic estuarine strata and eventually distal shoreface sandstone topped with a widespread fossiliferous horizon (Hettinger et al., 1993). Lower depositional environments include mudstone and sandstone of the lowstand-delta and tidal-flat, and beach and estuarine sandstone. After a type 2 unconformity little incision occurs, and channels may meander. Relative sea level fall eventually declines and channel gradients become gentle. Erosion may be reduced as will sediment load and the ability for channels to carry coarse-grained sediment. Floodplain reworking may be 
extensive due to lateral channel migration caused by a lack of accommodation space. Floodplain aggradation is thus inhibited. Isolated areas of the floodplain have the potential to develop mature soil horizons, however, channel migration severely decreases this potential (Wright \& Marriott, 1993).

\section{Transgressive Systems Tract (TST)}

The transgressive systems tract is bounded below by the transgressive surface and above by the maximum-flooding surface. The TST is brought on by the first flooding event following the maximum lowstand regression. Early stages of the TST restrict deposition to the incised valleys of a type 1 sequence. In type 2 sequences and later stages of the transgression, deposition is more widespread (Wright \& Marriott, 1993). Parasequences backstep in a retrodgradational parasequence set during transgression of the shelf. Successively younger parasequences step landward in a deepening upward fashion. East of the Kaiparowitz Plateau aggradationally and retrogradationally stacked parasequences of the Feron Sandstone onlap the Calico sequence boundary. Within the Kaiparowitz Plateau, fluvial and estuarine strata that overlie the Calico sequence boundary are younger than deposits to the east, this suggests they comprise a transgressive systems tract (Hettinger et al., 1993). However, the parasequences still fine upward. Coastal onlap indicates a major relative sea level rise on the continental margin of northwestern Africa. Landward and seaward migration of littoral facies indicate marine transgression and regression during this relative rise in sea level (Vail et al., 1977).

Condensed sections typically occur during times of late transgressive to early highstand. During this time the youngest parasequence of the TST in downlapped by the coincident clinoform toe of the overlying highstand systems tract (Van Wagoner et al., 1990). The 
condensed section consists of thin pelagic or hemipelagic sediments deposited during the landward migration of the parasequences and as the shelf is starved of terrigenous sediment. Within this deep basin interval is the greatest diversity and abundance of fauna within a sequence. Deposition is continuous but the section is commonly thin and accumulates over an expansive amount of geologic time. During maximum regional transgression of the shoreline condensed sections are most extensive. Two important implications for stratigraphy are entombed in condensed sections. The first is a condensed section is easily missed if biostratigraphic-age determination is not scrutinized. A major unconformity may be prompted due to an apparent time gap in the stratigraphic record. The second implication is that condensed sections commonly contain a more diverse fauna than rocks above or below (the exception to this is if the environment is poor such as an oxygen deficient basin). A continuous deep-water environment may be interpreted for the sampled interval (when fauna from successive condensed

sections are sampled in progressive sequences) if careful attention is not paid to the interpretation of depositional environments (Van Wagoner et al., 1990). Under these circumstances one may erroneously miss sequence boundaries where reservoir quality sandstones could have been deposited out in the basin.

\section{Highstand Systems Tract (HST)}

Highstand systems tracts are deposited during maximum sea level rise and coincident with sea level reversal. Widespread fluvial deposition is associated with the peak of highstand (Wright \& Marriot, 1993). This view, however, is not supported by Posamentier and Vail (1988). Wright and Marriot (1993) explained that the sequence stratigraphic model developed for non-marine sequences has not been rigorously tested. In their model maximum fluvial 
sedimentation occurs during trangresive and early highstand systems tracts. Vail and Posamentier (1988) showed maximum sedimentation to occur during late highstand and the lowstand systems tract. Wright and Marriot’s (1993) reasoning is, “fluvial deposits are more likely to accumulate during times when adequate accommodation allows the system to store sediment ... the ratio of channel to floodplain deposits will also depend on the ability of the system to store floodplain sediments”.

The HST is bounded below by the downlap surface and above by the next sequence boundary. Early highstand consist of an aggradational parasequence set. The late highstand is commonly composed of a series of progradational parasequence sets. Hettinger et al. (1993) explained that in the Kaiparowits Plateau the transgressive systems tract is overlain by $80 \mathrm{~m}$ of parasequences stacked in a progradational fashion, interpreted to represent the highstand systems tract. Typically the HST is characterized by aggradational, followed by progradational deposits. In most situations the HST is severely truncated by the overlying sequence boundary and if preserved is commonly prone to thin shale deposits. 